DEPARTMENT OF THE .INTERIOR

Franklin K. Lane, Secretary

UNITED States GEOLOGICAL SURVEY

George Otis Smith, Director

Professional Paper 100-B
BUREAU OF RINEG

LIBRARV

SPUNANE. WASH.

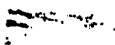

$J U N-21971$

DIEASB reputum

IO IIERAQY

\title{
THE COAL FIELDS OF THE UNITED STATES
}

\section{THE GOAL FIELDS OF OHIO}

BY

J. A. BOWNOCKER

State Geologist

WITH A COMPUTATION OF THE

ORIGINAL COAL CONTENT, OF THE FIELDS

BY

F. R. CLARK

Professional Paper 100, pages 35-96

Published October 29, 1917

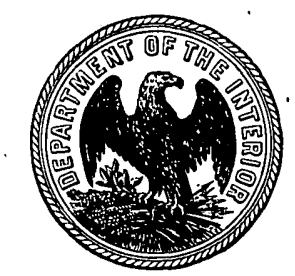

WASHINGTON

LIBRARY

GOVIRNMENT PRINTING OFFICE

1917

BIIREAI OF HINES

-IBRARY SPUNANE. NASH.

JUN -21971

PIHASE RETDRA

10 HeRARX 
723656309

$9 n$ 


\section{CONTENTS.}

Page.

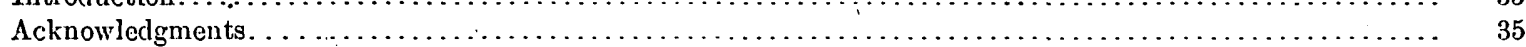

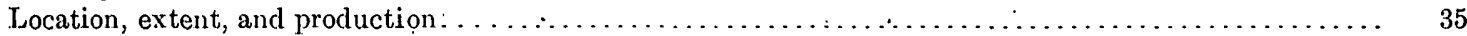

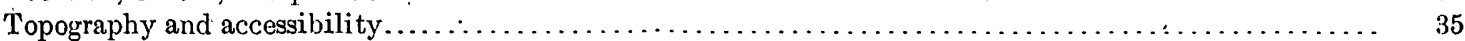

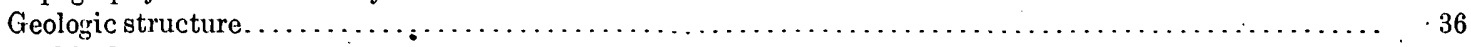

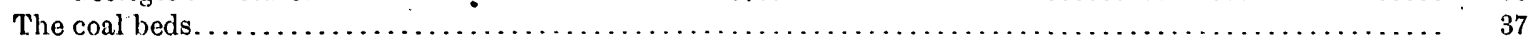

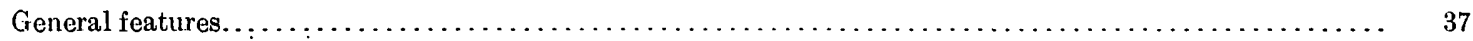

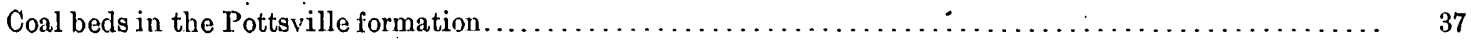

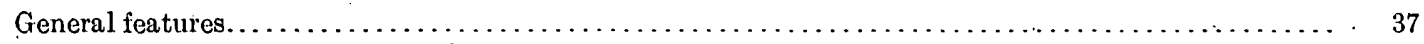

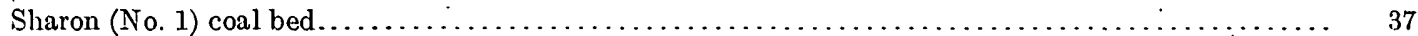

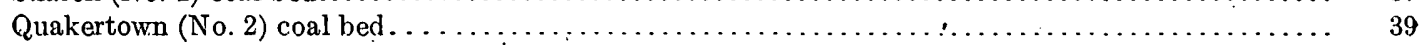

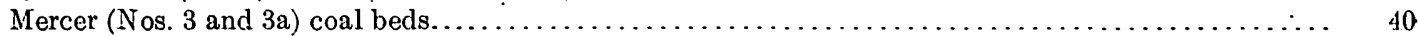

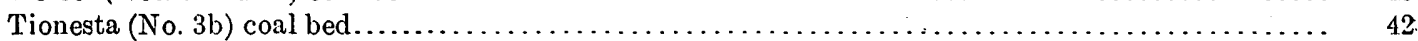

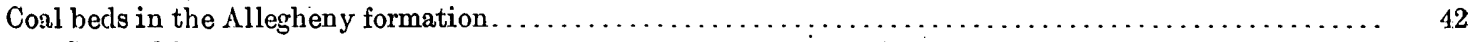

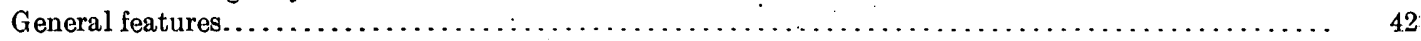

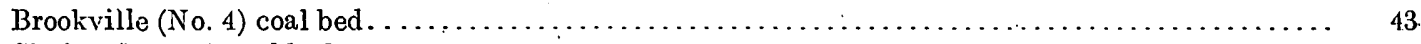

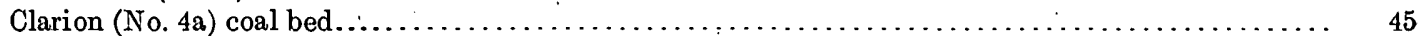

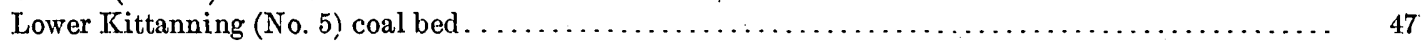

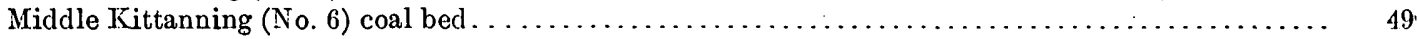

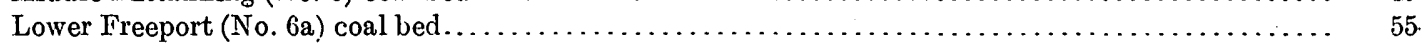

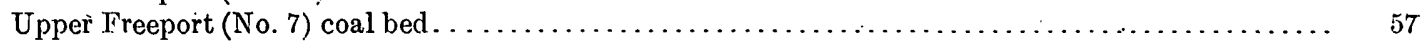

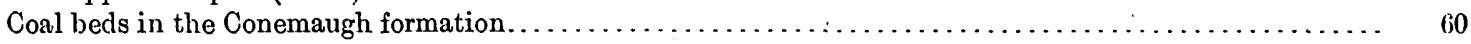

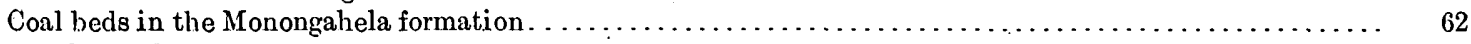

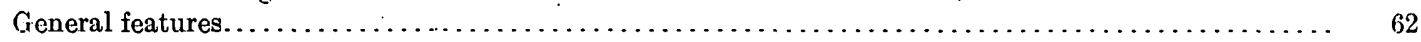

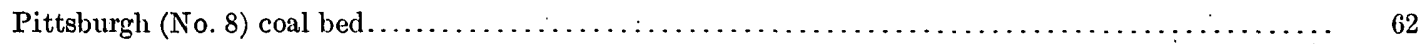

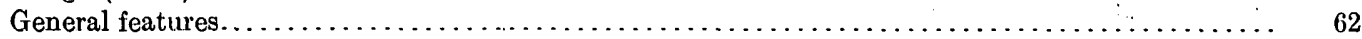

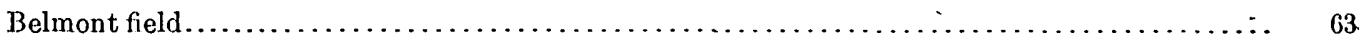

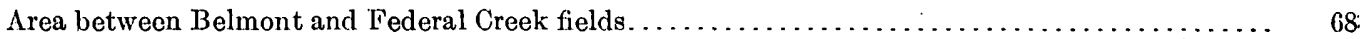

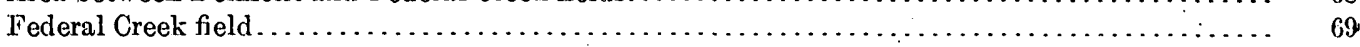

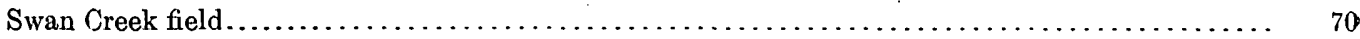

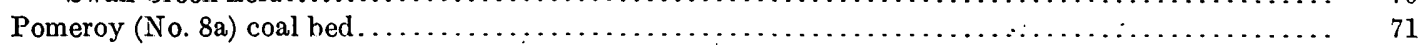

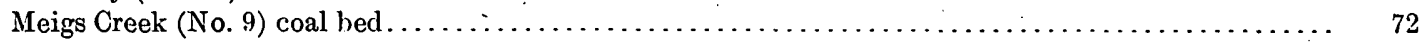

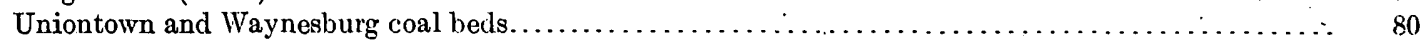

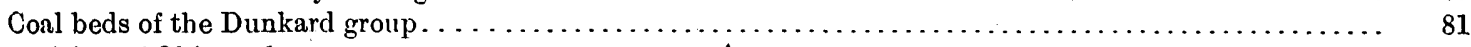

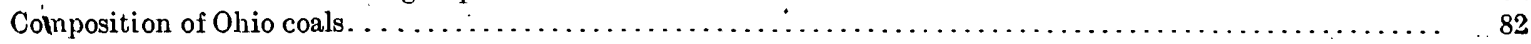

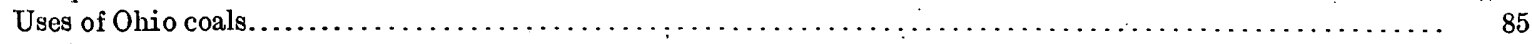

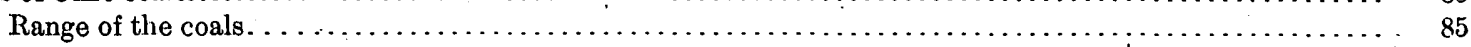

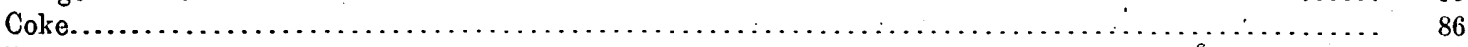

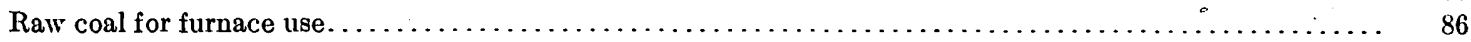

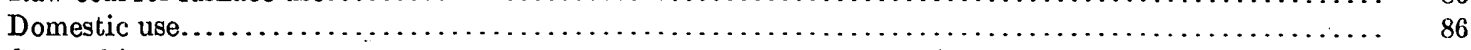

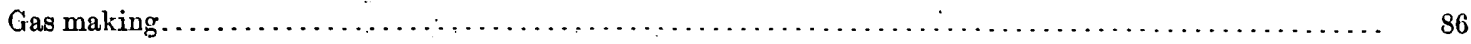

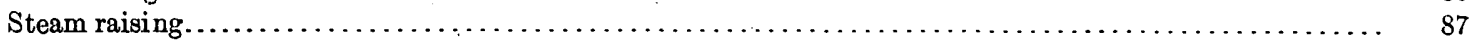

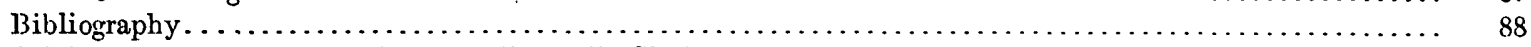

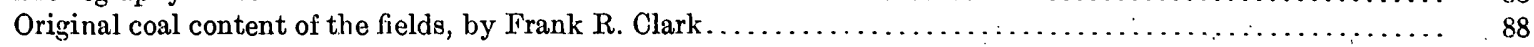

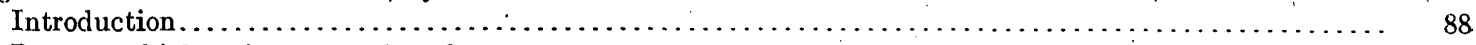

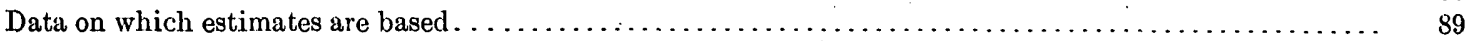

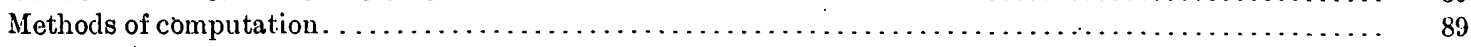

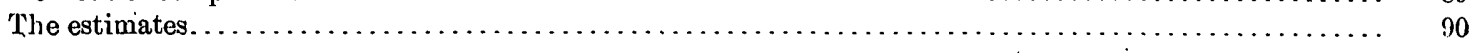

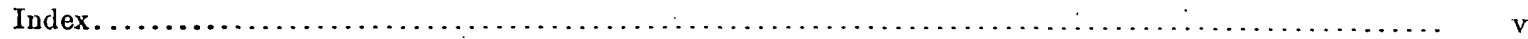




\section{ILLUSTRATIONS.}

Plate II. Map of Ohio showing outcrop of Upper Freeport (No. 7) and Pittsburgh (No. 8) coal beds or horizons.

III. Map of the Hocking Valley coal field (Middle Kittanning or No. 6 coal bed), southeastern Ohio...

IV. $A$, Upper Freeport coal bed in creek bank, Salineville, Columbiana County, Ohio; B, Shaft mine

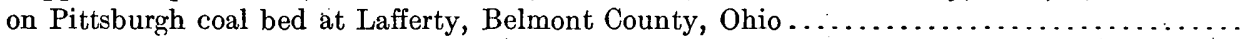

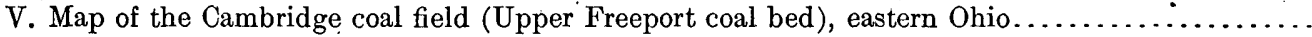

VI. A, Quarry in Mahoning sandstone member near Corning, Perry County, Ohio; $B$, Brush Creek limestone member of the Conemaugh formation near Dexter, Meigs County, Ohio.............

VII. Map of the Belmont coal field (Pittsburgh or No. 8 coal bed); eastern Óhio..................

VIII. $A$, Stripping Pittsburgh coal in Jefferson County, Ohio, with a steam shovei; $B$, Same strip pit as shown in $A$ after overburden has been removed.

IX. Map of the Pomeroy coal field (Pomeroy or No. 8a coal bed), southeastern Ohio.................

Frgure 4. Sections of Sharon (No. 1) coal bed, in Lawrence township, Stark County, north west of Massillon, Ohio

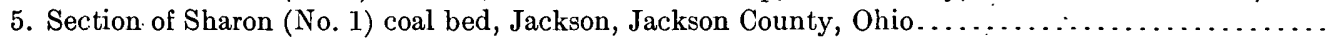

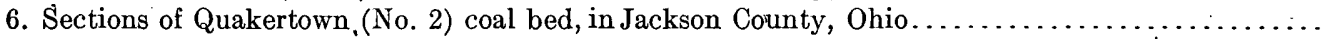

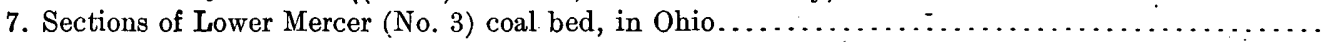

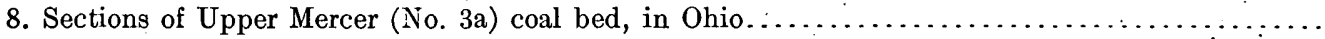

9. Sections of Brookville (No. 4) coal bed, in Stark County, Ohio . . . . . . . . . . . . . . . . . .

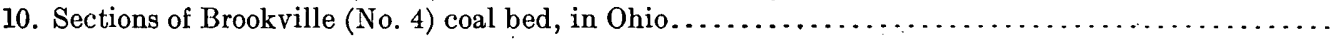

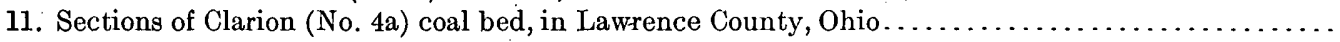

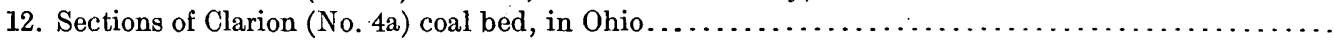

13. Sections of Lower Kittanning (No. 5) coal bed, in Ohio.

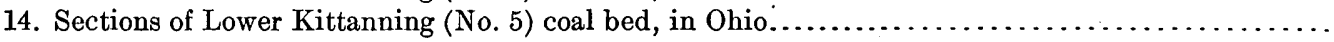

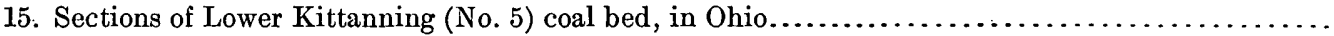

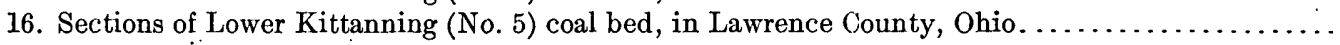

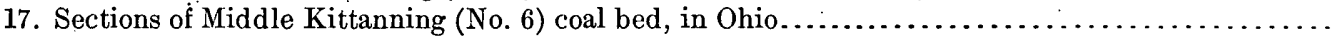

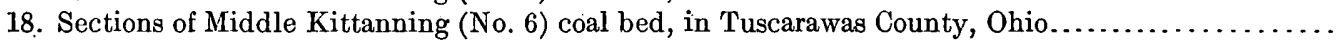

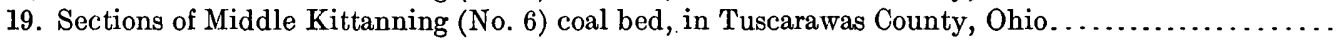

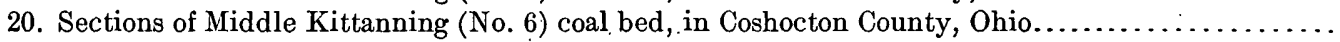

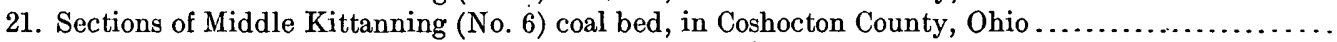

22. Sections of Middle Kittanning (No. 6) coal bed, in Muskingum County, Ohio.

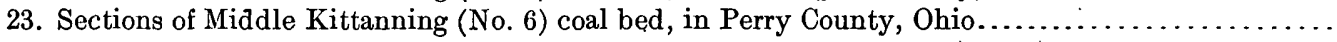

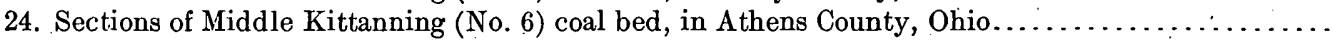

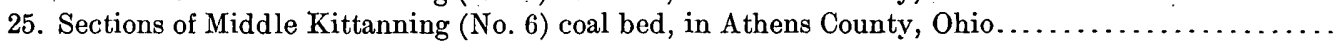

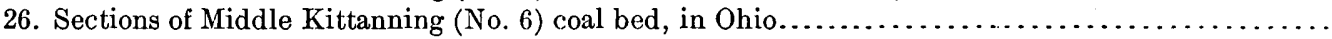

27. Sections of Middle Kittanning (No. 6) coal bed, in Gallia and Lawrence counties, Ohio............

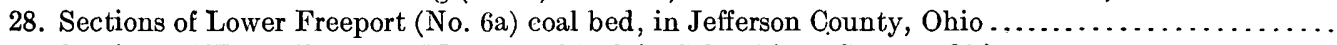

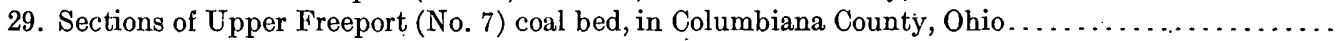

30. Sections of Upper Freeport (No. 7) coal bed, in Guernsey County, Ohio . . . . . . . . . . . . . .

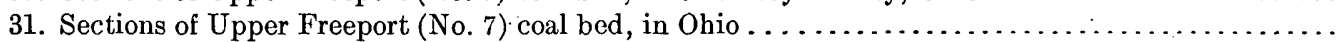

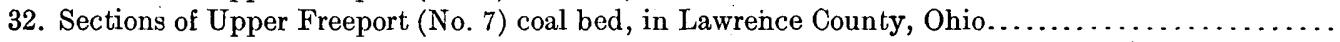

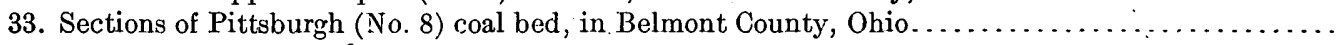

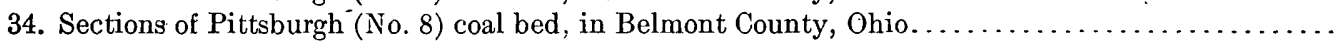

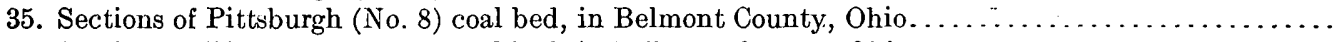

36. Sections of Pittsburgh (No. 8) coal bed, in Jefferson County, Ohio . . . . . . . . . . . . . . .

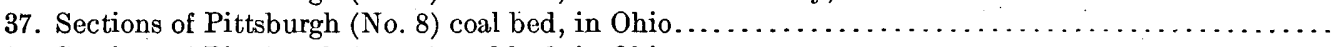

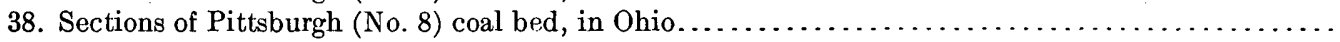

39. Sections of Pittsburgh (No. 8) coal bed, in Gallia County, Ohio . . . . . . . . . . . . . . . .

40. Sections of Pittsburgh (No. 8) coal bed, in Gallia County, Ohio . . . . . . . . . . . . . . . .

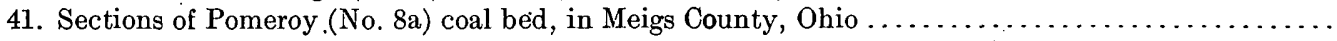

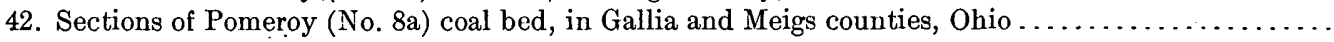

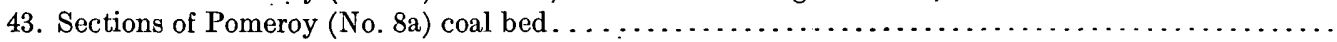

44. Sections of Meigs Creek (No. 9) coal bed, in Belmont County, Ohio . . . . . . . . . . . . . . . .

45. Sections of Meigs Creek (No. 9) coal bed, in Belmont County, Ohio . . . . . . . . . . . . . . .

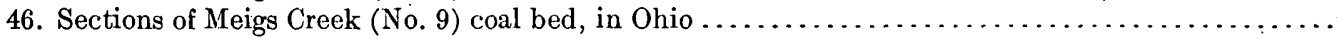

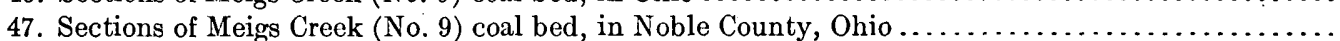

48. Sections of Meigs Creek (No. 9), coal bed, in Morgan County, Ohio . . . . . . . . . . . . . . . .

49. Sections of Meigs Creek (No. 9) coal bed, in Ohio .

Page.

\section{et. ${ }^{2}$} 52 


\title{
THE COAL FIELDS OF OHIO.
}

\author{
By J. A. BowNOCKER.
}

\section{INTRODUCTION.}

\section{ACKNOWLEDGMENTS.}

In preparing this paper the writer made free use of previous publications on the coal and the coal fields of Ohio. Many acknowledgments are made in the text, but the contributions of Dr. Edward Orton and the chemical work of Profs. N. W. Lord and E. E. Somermeier deserve special mention. Prof. F. A. Ray has prepared the map of the Hocking Valley field, which shows for the first time in print the "great fault." $\mathrm{He}$ has also prepared a map of the Cambridge field showing its possible extensions to the northeast and a map showing the eastward extension of the Pomeroy ficld. Dr. C. R. Stauffer has placed at the writer's disposal a section of the Dunkard group, with notes, and Mr. Wilbur Stout has supplied data bearing on the lower coal beds of southern Ohio. Many analyses of coals have been taken from bulletins of the United States Geological Survey and the Bureau of Mines and still others from Bulletin 9 of the Ohio Geological Survey:

\section{LOCATION, EXTENT, AND PRODUCTION.}

The coal fields of Ohio lie in the eastern part of the State, extending from near the shore of Lake Erie in Geauga and Lake counties southwestward to Scioto and Lawrence counties, on Ohio River. An area of about 12,600 square miles, nearly one-third of the State, is underlain by coal-bearing rocks. These fields form the western rim of the great Appalachian trough, which extends for 850 miles southwestward from northern Pennsylvania to central Alabama and has a width of about 180 miles in its widest part.

The Ohio fields contain 11 coal beds that are regularly mined for railroad shipment. Those beds, named and numbered from the bottom up, are the Sharon (No. 1), Quaker- town (No. 2), Upper Mercer (No. 3a), Clarion (No. 4a), Lower Kittanning (No. 5), Middle Kittanning (No. 6), Upper Freeport (No. 7), Mahoning (No. 7a), Pittsburgh (No. 8), Pomeroy (No. 8a), and Meigs Creek (No. 9). Two other beds, the Brookville (No. 4) and Lower Freeport (No. 6a), are regularly mined at some places to supply local demand, and eight others are occasionally mined at favorable places.

The Ohio fields are favored by good shipping facilities, both by rail and river, and lie within easy hauling distance of Lake Erie and of large manufacturing cities. Further, the area is not far from the center of population of the United States. These facts have made Ohio one of the large coal-producing States. In 1915 it ranked fourth in coal mined, and its output was over 6 per cent of the total for the United States. The following figures show the growth and magnitude of the coal-mining industry in Ohio:

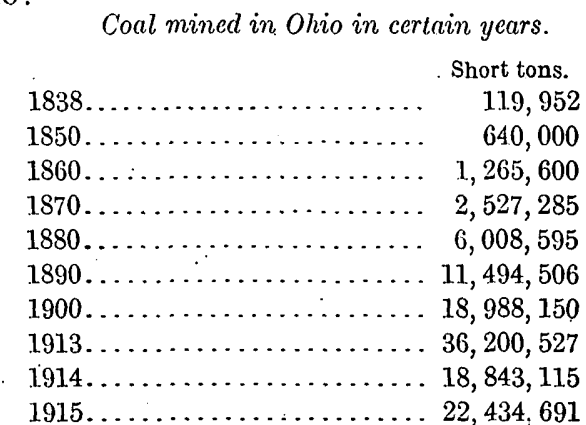

The total coal produced in the State up to the end of 1915 is $723,956,352$ short tons, or 6.64 per cent of the total quantity of coal mined to that date in the United States.

\section{TOPOGRAPHY AND ACCESSIBILITY.}

The coal-bearing area of Ohio is generally hilly and is most so in the counties that border Ohio River, where hills in places rise 500 feet. During the glacial epoch a great sheet of ice invaded the northern end of the coal 
fields, planing down the hills and filling the $/$ part of this trough is in West Virginia along a valleys and completely modifying the surface. line running almost direct from Pittsburgh, Pa., The ice extended as far south as middle Co- to Huntington, W. Va. Toward this deepest lumbiana, southern Stark, and northern Holmes part the rocks dip on both sides, those in Ohio counties. Consequently the counties of Portage, Mahoning, Columbiana, Stark, Summit, and Medina, lying north of this border, are in places rolling and in places nearly flat.

Numerous streams trench the coal-bearing rocks and along their western border have cut through them and are now at work on the underlying Mississippian formations. The Cuyahoga, Mohican, Walhonding, and Hocking are examples of such streams. Other streams that deeply trench but do not cut through the coal-bearing rocks are Ohio, Tuscarawas, Muskingum, Little Muskingum, and lower Hocking rivers.

The coal outcrops not only at its proper place along the western margin of the coal fields but also in many places in valleys miles east of the margin. The eastward dip of the strata is slight and carries the coal below drainage gradually, so that deep shafting is at present necessary in only a few places. It follows, therefore, that the coal is accessible to an unusual degree in comparison with that of many States.

The coal fields of Ohio are well supplied with railroads, being crossed by several of the large east-west systems and by other roads, which lead directly to the Great Lakes. These main lines, together with their many branches, make accessible almost all parts of this large region. Ohio River, which has trenched its way through the coal fields from Pittsburgh to a point below Ironton, should be one of the great highways for the movement of heavy freight, such as coal, but the shallowness of its water during the summer has prevented the development of such a trade. The Government is, however, engaged in building locks and dams to produce slack water deep enough for navigation, and when all these are completed it is supposed that much of the freight originating in this inland region will reach the coast by Ohio and Mississippi rivers.

GEOLOGIC STRUCTURE.

dipping generally southeastward from the outermost limit of the coal fields.

Although the coal-bearing rocks dip generally southeastward at a gentle rate they show many local exceptions, the most prominent of which are due to low folds or anticlines. Orton says:

There are some points, and especially in eastern Ohio, where the dip rises to $1^{\circ}$, which gives an inclination of 1. foot in 57 feet, or, in other words, about 93 feet to the mile, but the usual limits are between 20 and 40 feet to the mile. Throughout a considerable part of the Hocking Valley, for example, the dip is quite steady at an average of 27 feet to the mile, its direction here being about $65^{\circ}$ east of south.

Some of the most marked variations from the monotonous southeastern dip are found in Washington County, especially along Cow and Newell runs. On the bank of Ohio River, a short distance above the mouth of Newell Run, the Cambridge limestone is above drainage level and its vertical displacement, due to the arching of the rocks, is about 600 feet. On Cow Run the rocks form a dome, from whose center the coal dips away in all directions. This arch has raised both the Pittsburgh and Meigs Creek coal beds above drainage over a small area. The Cambridge anticline is one of the most prominent in eastern Ohio and causes the coal beds west of Cambridge to rise instead of dip eastward, as they normally would. Another departure from the normal is found in the southeastern corner of Belmont County, where for several miles a fold lifts the Pittsburgh coal above the beds of Captina Creek. Between Wellsville and East Liverpool is another low arch, but the coal in this locality is thin and the effect of the arch, so far as coal is concerned, is unimportant. The most notable upturning of rocks in the coal measures is near Mineral City, in Tuscarawas County, where the strata at one place are nearly vertical and the effects on the mining of the coal great. Small arches occur in the eastern part of Harrison

The coal-bearing rocks of Ohio are part of Gounty (where the Pittsburgh coal occurs), the great structural trough of the Appala- in central Belmont County, and in a few places chians. (See Pl. II, in pocket.) The deepest in counties to the southwest. 


\section{THE COAL BEDS. GENERAL FEATURES.}

The coal-bearing rocks of Ohio are all of Carboniferous age and are limited to the upper part of this system. The Carboniferous system, as recognized by the United States Geological Survey, consists of three series, named from above downward, the Permian, Pennsylvanian, and Mississippian. The coalbearing rocks belong to the Pennsylvanian series and to such part of the Permian series as is present.

The Permian and Pennsylvanian coal-bearing strata of Ohio, like those farther east, are divided into several formations, ${ }^{1}$ the Dunkard group ("Upper Barren Coal Measures"), including Greene and Washington formations; the Monongahela formation ("Upper Productive Coal Measures"); the Conemaugh formation ("Lower Barren Coal Measures"); the Allegheny formation ("Lower Productive Coal Measures"); and the Pottsville formation ("Conglomerate group").

Most of these formations, to which Orton assigned an aggregate maximum thickness of 1,700 feet, possess individuality; but the Pottsville and Allegheny grade into each other and the line of their separation is drawn somewhat arbitrarily. The Conemaugh contains a few thin coal beds, only one of which is now worked for railroad shipment and that at a single place. Shale predominates in this formation, but sandstone is common, and several thin beds of fossiliferous limestone occur, notably the Brush Creek, Cambridge, and Ames members, of marine origin. The formation is limited below by the top of the Upper Freeport (No. 7) coal and above by the base of the Pittsburgh (No. 8) coal bed. No formation in the Pennsylvanian is more definitely bounded.

The Monongahela formation has for its basal member the noted Pittsburgh coal bed, which in many places is very prominent on account of its thickness, and in other places is thin and inconspicuous. The upper limit of the formation is marked by the horizon of the Waynesburg coal, the coal itself being generally thin or wanting. The Dunkard group, which includes the highest formations in the geologic column in Ohio, forms the summit of the hills

1 Prosser, C. S., Ohio Gool. Survey, 4th ser., Bull. 7, p. 4, 1905. in the southeastern part of the State and is without workable coal beds-workable in this report being applied to beds which are either being mined at the present time or are of a thickness about equal to such beds. In general, the limit of workability at the present time in Ohio is about 2 feet.

COAL BEDS IN THE POTTSVILLE FORMATION. GENERAL FEATURES.

The Pottsville formation, formerly known as the "Conglomerate group," which according to Orton is 250 feet thick, extends irregularly from Trumbull County southwestward to Scioto County. It is broadest in northern Ohio, where it has a maximum width of approximately 40 miles, and it narrows southwestward to perhaps less than 16 miles. Its basal member is the "Pottsville" or Sharon conglomerate, and its summit is formed by the Homewood sandstone member. Overlying the Homewood is the Brookville coal, which constitutes the basal member of the Allegheny formation. It must be confessed, however, that the upper limit of the Pottsville formation is not sharply marked and that, so far as Ohio is concerned, no very good reason exists for separating it from the overlying Allegheny formation. However, the Ohio geologists have always accepted the classification of Pennsylvania workers, who divided the lower coäl measures into two formations, and it seems best to continue that division. The following table shows the sequence of coals and interbedded rocks as given by Orton:

General section of the Pottsville formation in Ohio.

Homewood sandstone.

Tionesta (No. 3b) coal.

Upper Mercer group:

Ore.

Limestone.

Upper Mercer (No. 3a) coal

Lower Mercer group:

Ore.

Limestone.

Lower Mercer (No. 3) coal.

Upper Massillon sandstone.

Quakertown (No. 2) coal.

Lower Massillon sandstone.

Sharon (No. 1) coal.

SHARON (NO. 1) COAL BED.

The Sharon is the lowest of Ohio coal beds and is workable in only the extreme parts of the coal fields of the State-Massillon and vicinity 
in Stark County and Jackson and vicinity in Jackson County.

Massitlon field.-The Massillon field is by far the larger producer; in fact, were it not for that field the coal would scarcely be noticed in these pages. The area of the Massillon field is, however, small, though it includes parts of four counties. At present the coal is mined for railroad shipment in parts of Lawrence and Tuscarawás townships, Stark County; part of Sugar Creek Township, Wayne County; a small area near Nimisila, a hamlet in Franklin Township, Summit County; and near Deerfield station in the extreme southeast corner of Portage County. However, Lawrence and Tuscarawas townships of Stark County have always been considered the "heart of the bed," and the best of the coal is still found within their borders. East of Tuscarawas River the Sharon coal is nowhere present in the vicinity of Massillon but is found to the north in Summit County. The coal is lnown in the market as the Massillon coal. In 'July, 1915, 14 mines had railroad connection. The annual production of the field 15 years ago was about 1,000,000 tons; in 1915 it was about 500,000 tons, and it will continue to decrease year by year until the bed is exhausted. A little prospecting with the drill is occasionally done, but the life of the field will probably not extend much beyond 10 years.

-The Geological Survey of Ohio has never mapped this coal for the reason that it does not form or even resemble a continuous bed but consists of a series of basins or pockets whose limits can be determined only by drilling or mining. The largest basin or pocket is said to have had an area of about 300 acres; and at present mines for railroad shipment are opened in basins having no greater area than 10 acres. Many of the basins contain masses of rock, known as horsebacks, whose area may vary from 1 to 5 acres. Commonly the coal bed thins and its quality deteriorates toward the margins of the basins, but in places it ends abruptly. Slope mining is possible in places where the streams have cut through the coal bed, and such mines are easy to drain, but at present nearly all the mining is done through shafts, most of which are less than 200 feet deep.

The coal bed differs from other coal beds of Ohio in being without persistent partings.
Some pyrite is present, especially along the borders of the basins or where horsebacks occur. Nevertheless the coal is unusually free from impurities, greatly enhancing the esteem in which it has always been held. The bed, in greatest thickness, measures $4 \frac{1}{2}$ to 5 feet, but it changes sharply and may pinch out in a short distance. Two feet is generally the minimum thickness now mined. A variation in thickness from 5 inches to 2 feet 6 inches is shown in figure 4 , which represents two sections in Lawrence Township, Stark County. The changes are due to unevenness in both roof and floor, but perhaps more commonly to those in the roof. In places the floor is notably uneven, and the coal may lie on a low swell instead of a flat surface. Shale commonly forms the roof and clay the floor, but in places sandstone forms one or both. The coal is open burning (that is, it does not fuse during combustion), lustrous, produces a good proportion of lump, and stands transportation .well.

Films of calcium carbonateknown as "white-cap" are common on the surface of the coal and give it a spotted appearance. The coal

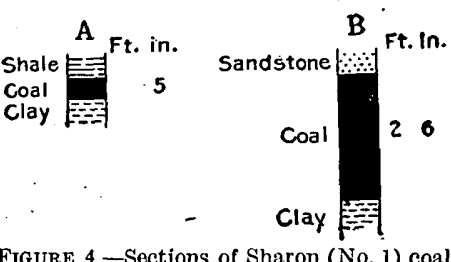

IGURE 4.-Sections of Sharon (No. 1) coal bed in Lawrence Township, Stark County, northwest of Massillon, Ohio. along the western margin of the field, although good, is not quite up to the highest standard of the bed. The great use of the coal has always been for domestic purposes. It is clean, ignites easily, makes a hot fire, and produces little ash. It contains an average of about $53 \frac{1}{2}$ per cent of fixed carbon, 37 per cent of volatile matter, $5 \frac{1}{2}$ per cent of moisture, and 4 per cent of ash. Fifteen samples gave an average of 4.2 per cent of ash, two of these showing less than 2 per cent and the highest 6.6 per cent. Cleveland has always been the principal market for the coal.

Formerly there was, in the Mahoning Valley, a small area of the Sharon coal which bore a fine reputation. It was known as the Mahoning block coal and was used raw in blast furnaces and for domestic purposes. This coal is at present shipped from the Mahoning Valley from only one mine near Lowellville, but it is worked in a small way for local use at other places. 
Jackson County. - The other field of Sharon conl lies in Jackson County, in the southern part of the State, but it is smaller and of much less importance than the Massillon field. It is locally known as the Jackson Shaft coal. The conl is at its best in both thickness and quality under the town of Jackson, where it measures 3 to 4 feet. (See fig: 5.) It was discovered in 1863 and is nearly worked out. It is found in scattered hills and ridges west of Jackson, espocially in Liberty Township, and is mined for railroad shipment and for use among farmers. Two furnace companies mine the coal for their own use. Wilber Stout estimates that the arca of Sharon coal of workable thickness in Jackson County is about 25 square miles but "duo to wants, thin places, shaly conditions,

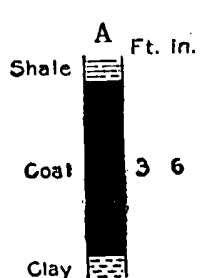

clay $=-1$

Ficure 5.-Section of Sharon (No. 1) coal bod, Jackson, Jacks on County, Ohio. and weathered outcrop, not to exceed 50 per cent of this is workable area."

A sample of Sharon coal from Decatur mine No. 1, 5 miles west of Jackson, shows on analysis moisture 13.6, volatile matter 31.8 , fixed carbon 50.4 , ash 4.2 , and sulphur 0.86 per cent. Its heat value is 11,680 B. t. u. ${ }^{1}$ Other samples from the same general locality show a greater heating capacity, the highest being 14,220 B. t. u.

The coal bed commonly has an uneven floor and hence varies greatly in thickness. It is hard, dry burning, ${ }^{2}$ low in ash, very low in sulphur, and is still used raw in the blast furnaces for making pig iron. . It is excellent for domestic purposes.

\section{QUAKERTOWN (NO. 2) COAL BED.}

The Quakertown (No. 2) coal, known also as the Wellston or Jackson Hill bed, is the second coal in importance in the Pottsville formation. The position of this bed with reference to the Sharon is well shown by the following section, measured byWilber Stout:

Section in sec. 18, Lick Township, Jackson County, Ohio.

Shale................................. $10 \quad 0$

Coal, Quakertown, reported thickness......... 2 6 Covered............................... $24 \quad 0$

$1 \mathrm{~A}$ British thermal unit (B. t. u.) is the quantity of heat required to raiso the temperature of 1 pound of water $1^{\circ} \mathrm{F}$. at or near $39.1^{\circ} \mathrm{F}$, the temperature of maximum density. British thermal units may be reduced to pound calories by multiplying by 0.5556 and to French calorics by multipying by 0.252 .

2 'The term dry burning is applied to a coal that does not fuse during combustion and that burns slowly.
Ft. in.

.

Covered............................... 50

Shale, part covered........................ 220

Coal, Sharon, reported thickness............ 28

Covered ................................ $2 \quad 0$

Conglomerate, Sharon................... $40 \quad 0$

1412

The one known important area of Quakertown coal is in Jackson County (Coal, Washington, and Milton townships), where, according to Orton, it was originally 9 miles long and had a maximum width of 4 miles. The coal was discovered by H. S. Bundy in 1872 in sinking a shaft for the Sharon or Jackson Shaft coal for furnace use. The coal soon proved its value for steam and domestic purposes, and its output grew rapidly, making Jackson County for a time first in coal production in the State. Although coal is obtained from other beds in the county, that derived from the Quakertown is by far the largest, and the variations in output are due largely to the conditions of mining in that bed.

Production in short tons of coal in Jackson County, Ohio.

\begin{tabular}{|c|c|}
\hline 1885 & 791,608 \\
\hline 1890 & 836,449 \\
\hline 1902 & $2,412,509$ \\
\hline 1910 & 878,656 \\
\hline 1913 & 587,044 \\
\hline 191 & 532,8 \\
\hline 1915 & 565,3 \\
\hline
\end{tabular}

The maximum output was in 1902 and since that year production has declined notably and will doubtless continue to do so unless other beds in the county are much more extensively worked than they are at present.

Stout says that "The best of the entire field was in the vicinity of Wellston, where the bed had a regular thickness close to 4 feet [see fig. 6] and the coal whs of excellent quality." The coal in this area is now exhausted, except for small blocks left in the old mines where the cover is thin or the dip such as to cause trouble from water. Eastward from Wellston the coal bed gradually thins, but no drill records defining this border of the field have been obtained. The largest body of minable Wellston coal at present lies in this area.

The coal is found in workable quantity along the southern border of Washington Township, but farther north, except in secs. 10 and 15 , it is of such poor quality as to be worthless or is cut out entirely by sandstone. 
Coal Township contained the largest area of the Quakertown coal, nearly its entire surface being underlain by it. Moreover, the thickness reached 4 feet and the quality rivaled the best in the field. However, the coal is practically exhausted.

The coal bed should lie above drainage in southern Lick, eastern Scioto, western Franklin, and eastern Hamilton townships, but it is
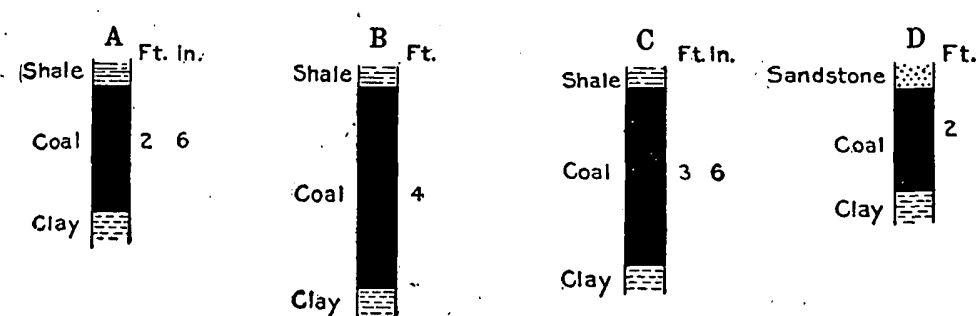

Figure 6.-Sections of Quakertown (No. 2) coal bed in Jackson County, Ohio. A, Jackson; B, Wellston; C, Glen Roy; D, Washington Township. County. respects first class for domestic purposes. Another small pocket of this coal has been reported in the western part of Hocking

General features.--The Lower Mercer (No. 3) and Upper Mercer (No. 3a) coal beds may be easily followed across the State because of the limestones of the same names under which they lie. However, they are not of great value. The Lower Mercer, although mined in a few places for local use, is nowhere worked on a basis for railroad shipment. The Upper Mercer is mined in a larger way in Coshocton County.

either wanting or is represented by only a few inches of coal or bony shale. For 25 years efforts have been made with the drill to discover minable coal on the east border of the county and farther east in Vinton County and thus extend the producing territory, but only small areas of good coal, most of the beds thin, have been discovered. The coal usually has an even floor, but in places it forms knolls, over which the bed is thin. The roof is of shale and of good strength.

The Wellston coal is fairly tender and does not stand mining and transportation well. It is bright and free from shale or clay except near the roof and floor. Sulphur and ash are low. The coal is open burning. As a domestic coal it is excellent, and it is to be regretted that its use could not have been restricted to that purpose. According to an analysis made by E. E. Somermeier of a sample taken in the Wainwright mine, in sec. 4, Milton Township, the coal shows moisture 9.3, volatile matter 33.0, fixed carbon 54.2, ash 3.5, sulphur 1.25, and nitrogen 1.39 per cent. Its heat value is 12,530 B.t. u.

Within the past few years a pocket of Quakertown coal has been located and mined in Elk Township, Vinton County, a few miles north of McArthur. The coal, where mined, usually ranges from 2 feet 6 inches to 4 feet in thickness. It has a shale roof, clay floor, and is free from impurities., The coal in places has a few inches of cannel and seems to be in all
Holmes, Mahoning, Tuscarawas, and Stark counties. - The relations of the Mercer to both the overlying and the underlying coals are shown in the following general section for Holmes County by A. A. Wright:

General section of the Mercer coals and the adjacent strata, Holmes County, Ohio.

Coal, Brookville (No. 4). Feet.

Sandstone and shale........................ 20 Coal, Tionesta (No. $3 \mathrm{~b}$ ).

Sandstone, shaly ................ Coal, Upper Mercer (No. 3a).

Shale............................. 30

Limestone, Lower Mercer, thin. Coal, Lower Mercer.

Shale .............................. 22 Coal (No. 2a).

Sandstone, Upper Massillon ................. 38 Coal, Quakertown (No. 2).

Sandstone, Lower Massillon................ 40 Coal, Sharon (No. 1).

The Mercer coals and associated limestones are found in Mahoning County; and both coal beds are in places mined by farmers. The lower bed was once worked in a small way for railroad shipment in this county, and the upper bed has long been a local source of fuel near the village of Canfield. Both coal beds have been mined by farmers in Holmes and Tuscarawas counties, but both are much broken by partings in Holmes County and of little or no importance in Stark County. (See fig. 7.) 
Coshocton County.-Western Coshoct on mined in this county. In Richland Township County contains the best-known field of Mer- it is 28 inches thick and is worked by farmers. cer coal in Ohio. The Upper Mercer (No. The Upper Mercer coal has long been mined 3a) coal, here known as the Bedford can- for local use in the vicinity of McArthur, where nel coal, is workable, according to Orton, over it is known as the Newland coal. At its best about 1,500 acres. It lies in the northern part of Bedford Township and the adjacent part of Jofferson. The coal has a maximum thickness of 9 fect, not all of which, however, is cannel.

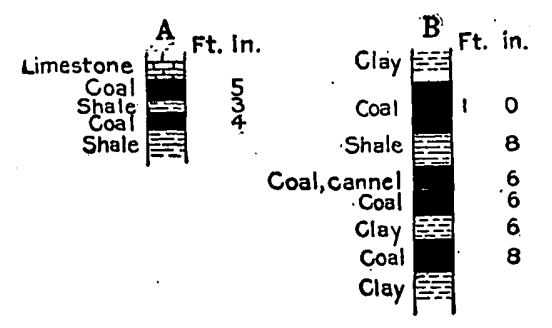

Figure 7.-Sections of Lower Mercer (No. 3) coal bed in Ohio. A, Hardy Township, Holmes County; B, Washington Township, Hocking County.

Sections show a bed of bituminous coal above the cannel, but its quality is usually not good. (See fig. 8.)

Section of Upper Mercer coal bed in old Mowrie mine, Jefferson Township, Coshocton County, Ohio.

Limestone and flint, Upper Mercer.

Coal, bituminous, upper part pyritiferous,

lower part soft. . . . . . . . . . . . . . . . . Clay.

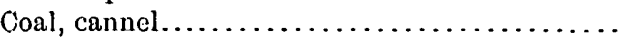

The canncl is strong and tough and does not disintegrate when exposed to the weather or to transportation.

M.uskingum and Licking counties.-Muskingum County has both Mercer coal beds, but here the lower is the more important. It has been mined in a very small way in Hopewell Township in the western part of the county, and just over the line in Licking County it constitutes the well-known Flint Ridge cannel. The coal here is 3 to 4 feet thick and was formerly used for distilling illuminating oil. It contains some layers of shale, which makes it high in ash. Its area is small, and it is worked only for local needs.

Perry, Hocking, and Vinton counties.-Perry and Hocking counties have both coal beds, but it is rare that either attains a thickness of 2 feet. Vinton County makes a little better showing. Near Zaleski the Lower Mercer coal has a good thickness, but it is dirty and can not compete in the market with other coal the bed measures 5 feet, part of which is cannel coal.

Juckson County.-The Lower Mercer coal has been mined by farmers in Hamilton and northern : Washington townships, Jackson County, where it measures 24 to 30 inches and is of good quality. The Upper Mercer coal is also found in Jackson County with a thickness of 18 to 30 inches. Jefferson, Lick, and Bloomfield townships have the best beds, but even they are too thin to be of much value.

Scioto County.-In Scioto County the Lower Mercer coal is found in the eastern row of townships, but it does not exceed 24 inches in thickness. The Upper Mercer coal has long been mined for local use in the vicinity of South Webster, Bloom Township, where it is known as the Webster block coal. The bed usually is in two benches separated by a thin layer of clay or shale. The upper bench averages 16

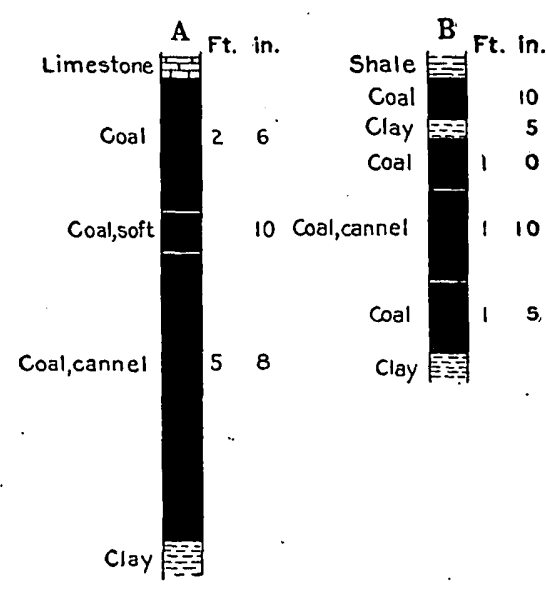

Figure 8.-Sections of Upper Mercer (No. 3a) coal bed in Ohio. $\dot{A}$ Bedford Township, Licking County; $B$, Elk Township, Vinton County.

inches in thickness and the lower bench, where present, 6 to 8 inches.

Section of Upper Mercer coal bed on land of John Grant, in sec. 22, Bloom Township, Scioto County, Ohio.

Sandstone, shaly.

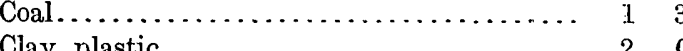

Coal.............................. ${ }^{2}{ }_{8}$

Clay, plastic...................... $4^{\circ} 0$ 
In mining, the undercutting is made in the clay below the coal, so that none of the fuel is lost. The coal burns with a long flame, owing to its large content of volatile matter; is nonclinkering, and is low in sulphur. It has an excellent reputation for domestic purposes. Near Bloom Junction the coal is a cannel, about 2 feet thick. This is the best-known and bestdeveloped field of the Upper Mercer coal in southern Ohio.

Lawrence. County.-Both coal beds are in Lawrence County, but neither is of much value. The Lower Mercer bed attains a thickness of 2 feet in Elizabeth Township. and is occasionally mined by farmers. The Upper Mercer coal is mined in Hamilton, Upper, and Elizabeth townships. The section of the coal bed in these townships is similar to that at South Webster (p. 41); the upper bench has a maximum thickness of 2 feet and is of very good quality. The lower bench is about half as thick.

TIONESTA (NO. 3b) COAL BED.

The Tionesta (No. 3b) is the highest coal bed in the Pottsville formation and has the least value. It lies 20 to 30 feet above the Upper Mercer limestone and is rarely of workable thickness even for local use.

Perhaps the best-known field of this coal is in Lawrence Township, Tuscarawas County, where the bed has been mined, off and on, for many years. It is known in that territory as the Bolivar coal. A section, measured by Orton, is as follows:

Section of Tionesta coal bed at Bolinar, Ohio. Shale, dark.

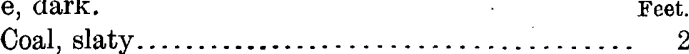

Clay and coal streaks..................... 1 Clay.

Coal ............................... 2

Near Jackson School, sec. 34, Richland Township, Vinton County, the Tionesta coal bed has a maximum thickness of 5 feet, but the coal is bony and high in ash. Shale overlying this coal in Vinton, Jackson, and Scioto counties is usually highly fossiliferous. At Monroe Furnace, Jackson County, the coal is mined for railroad shipment. The bed is about 4 feet thick and consists of two benches separated by an inch of shale. The area underlain by it, however, is small. The coal is mined for local . use on Clinton Ridge in Vernon Township,
Scioto County, and it has been worked in Decatur and Washington townships, Lawrence County, where its maximum thickness is 3 feet.

COAL BEDS IN THE ALLEGHENY FORMATION. GENERAL FEATURES.

The Allegheny formation, formerly known as the "Lower Productive Coal Measures," contains the most extensive and valuable coal beds of Ohio. It extends in outcrop from Mahoning to Lawrence County and, as reported by Orton, has a thickness of 250 feet. The Brookville (No. 4) coal is the lowest member of the formation and the Upper Freeport (No. 7) coal is the highest. The formation contains five coal beds that are now mined in a large way, and one of these is of workable thickness above drainage in every county where it is due.

Section of the Allegheny formation at'Magnolia in southern Stark County, Ohio.

[By Edward Orton.]

Clay, shale, sandstone, and concealed.......... 450

Sandstone, Lower Freeport, ${ }^{1}$ and conglomerate. . $30 \quad 0$

Concealed............................. $55 \quad 0$

Coal, Middle Kittanning (No. 6)............ $3 \quad 0$.

Clay.................................. 30

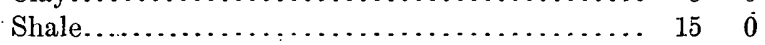

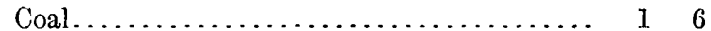

Shale.............................. 110

Coal, Lower Kittanning (No. 5)............ 3,6

Clay .................................. 3

Shale and sandstone....................... $5 \quad 2$

Limestone, Putnam Hill....................... 1.

Coal, Brookville (No. 4).................. $5 \quad 5 \quad 0$

The Lower Freeport (No. 6a) coal does not appear in the section. It probably lies in. the "concealed" mass above the Freeport sandstone member.

Generalized section of the Allegheny formation in Lawrence County, Ohio.

[By Wilbar Stout.]

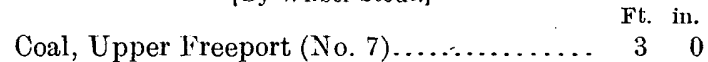

Shale and sandstone...................... $42 \quad 0$

Coal, Lower Freeport (No. 6a)........... 1.0

Shale and sandstone...................... $37 \quad 0$

Coal, Middle Kittanning (No. 6).............. 14

Shale and sandstone..................... $27 \quad 0$

Iron ore, Red Kidney.................... 4

Shale and sandstone...................... 38

Clay, Oak Hill.............................. 30

${ }^{1}$ This is the Freeport sandstone member of United States Geological Survey reports. 


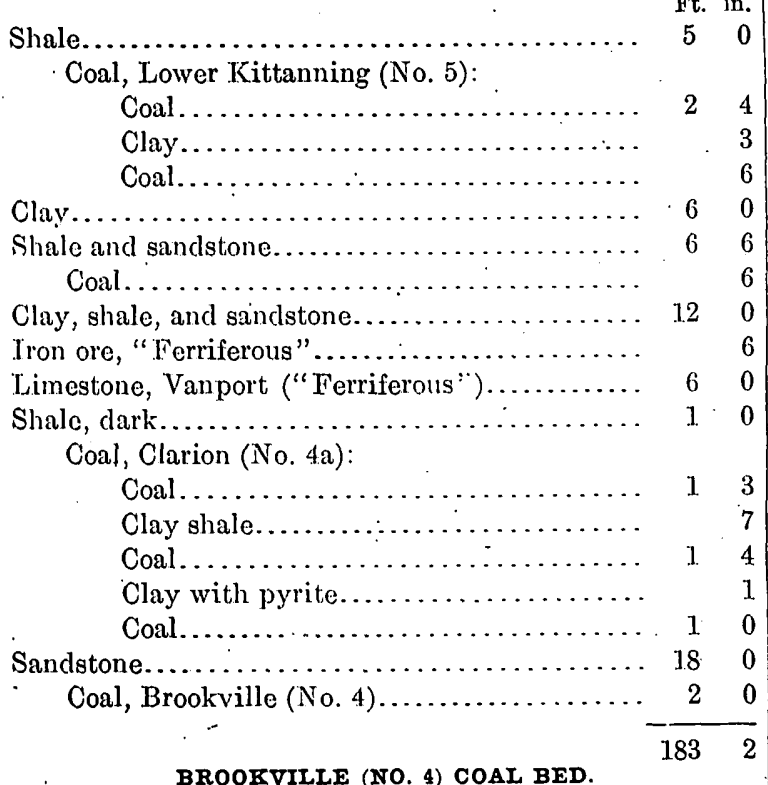

The Brookville (No. 4) coal bed is the basal member of the Allegheny formation. It lies immediately below the Putnam Hill limestone member and for that reason is easily identified. It can readily be traced across the State, but at present it is not an important source of fuel.

Stark County.-The best-known area of the Brookville coal is in Stark County. It is not mined for railroad shipment, though it is used in large quantity for burning lime, for fuel at Canton, and for domestic use in several villages' and among the farmers. It is mined a mile southwest of the hamlet of Greentown, in Lake Township, and near New Berlin, where it is used in burning lime. The coal is reported to be 18 inches thick at Middlebranch. It extends practically across the county from north to south, but its width of outcrop is less definitely established. Orton mentions 4 miles, but near the southern border of the county there are workable areas 12 miles apart in an east-west direction. . The largest mines are only a mile or two north of Canton, and that city furnishes an excellent market.

Section of Brookville coal bed in mine of Edgefield Coal Co., 2 miles north of Canton, Ohio.

Shale. [See fig. 9, A.] $\cdot{ }^{-}$Ft. in.

Jimestone, Putnam Hill.

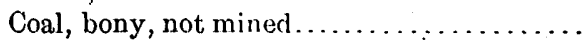

Coal, "top".........................

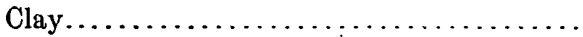

Coal, "bottom":

Coal, bony, not mined

ed.....................

Total section

Total coal.
A few hundred feet from this section the "top" and "bottom" coal conjointly measure 4 feet 8 inches, but the company counts on only 3 feet 6 inches of good coal. Thin shale or clay partings are not common; but there is considerable pyrite. The coal is reached by a slope, but it lies so near the surface in the surrounding country that much of it has been removed by streams.

South of Canton the Brookville coal is mined in the vicinity of North Industry and Howenstein, and it has been worked in the vicinity of East Sparta. It is used for burning lime, and little or none of it is shipped by rail.

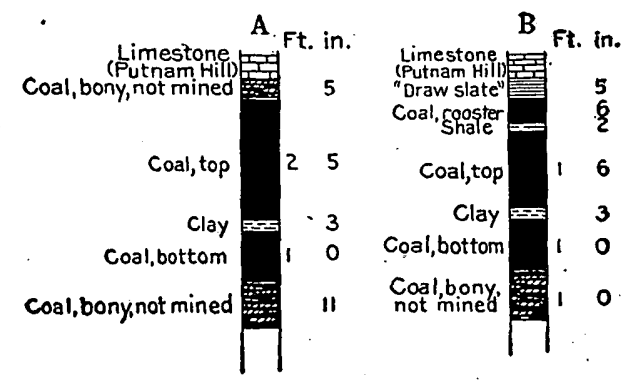

FIGURE 9.-Sections of Brookville (No. 4) coal bed in Stark County, Ohio. A, 2 miles north of Canton; B, 1 mile south of North Industry.

Section of Brookville coal bed in Agricultural \& Commercial Lime Co.'s mine, 1 mile south of North Industry, Ohio.

[See fig. 9, B.]

Limestone, Putnam Hill............... $\quad \begin{array}{r}4 \\ \quad\end{array}$

"Draw slate".......................... 5

Coal, Brookville:

Coal, "Rooster," mined............. . 6

Shale.........................

Coal, "top"...................... 1.6

Clay.......................... 3

Coal, "bottom".................. I. 0

Coal, bony, not mined ............... 1.0

$8 \cdot 10$

The quantity of the coal in this part of Stark County appears to be large, and though its quality is not first class it does very well for ordinary uses.

Section one-half mile east of Justus, southwest corner of Stark County.

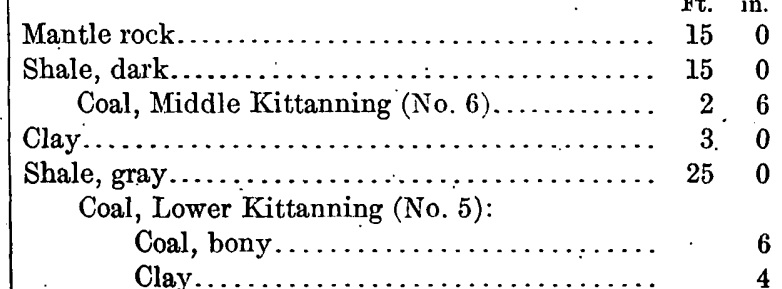




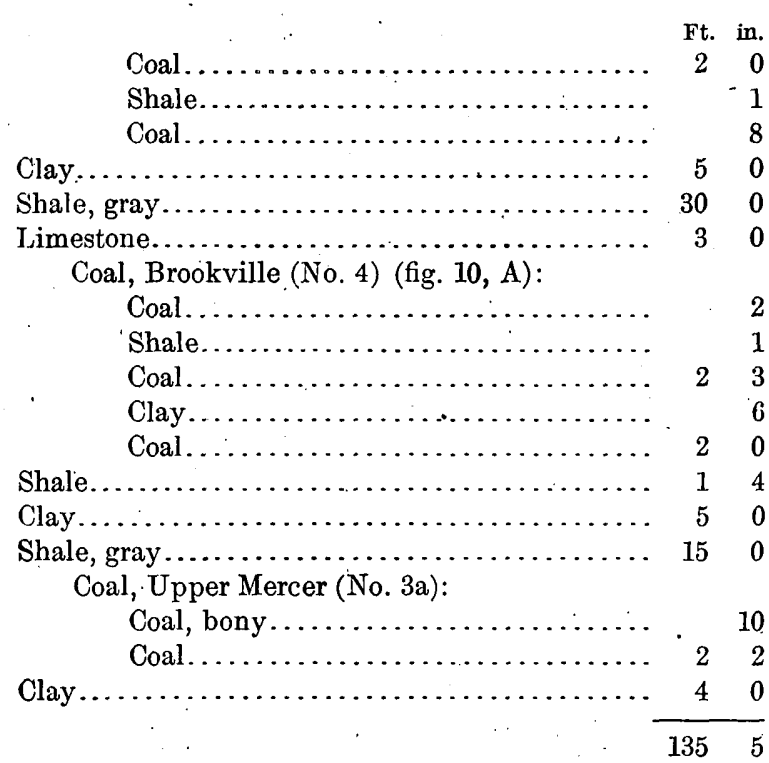

The Lower Kittanning and Brookville coals are mined at this place, and plans are being made to work the Upper Mercer at an early date.

Tuscarawas, and Coshocton counties.-The Brookville coal is commonly thin and unimportant in Tuscarawas County. In western Coshocton County it thickens and is an important source of fuel among the farmers in Jefferson, Bedford, and Newcastle townships, where it reaches a maximum thickness of 4 feet. The following section is reported by Orton:

Section of Brookville coal bed in Moore's mine, Jefferson Township, Coshocton County, Ohio.

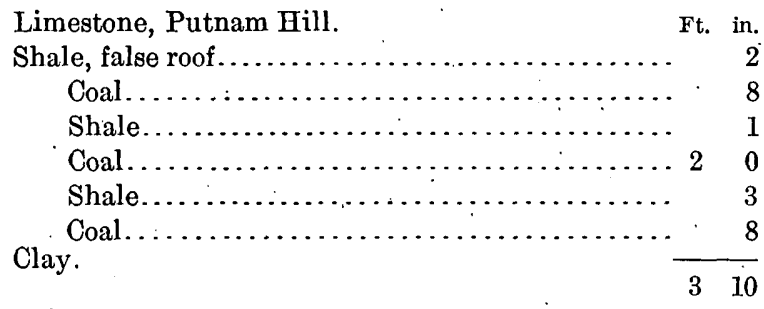

The coal is at least of fair quality and by some is preferred to the cannel coal of the vicinity.

Muskingum, Perry, and Hocking counties.The Brookville coal is found in the western portion of Muskingum County, but here it is less than 3 feet thick and hence is of little importance. Years ago a small mine was opened in this bed at Zanesville. The coal is found in Perry and Hocking counties, but it is thin and not mined.
Vinton County.-The Brookville coal attains workable thickness in Vinton County, where it has long been mined in Elk, Swan, Madison, and Clinton townships under the name Winter's coal or "Flint vein," the latter name being given because of the presence in places of a bed of flint between the two benches of coal. This coal varies considerably in thickness in this vicinity, as is shown by the following section and also by figure $10, \mathrm{~B}$.

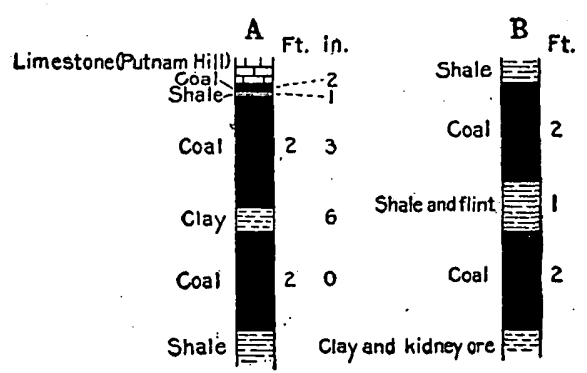

Figure 10.-Sections of Brookville (No.4) coal bed in Ohio. A, Justus, Stark County; B, McArthur, Vinton County.

Section of Brookville coal bed at McArthur, Ohio. Shale.

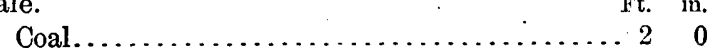

Shale................................. 3

Coal........................... 2

Clay and kidney ore. $\quad \frac{23}{43}$

The coal was formerly worked at Zaleski for railroad shipment, but the mine was abandoned years ago. The coal varies considerably from place to place but is of fair quality for steam and domestic purposes.

Jackson County. - The Brookville coal is mined in a small way for railroad shipment in Milton Township, Jackson County.

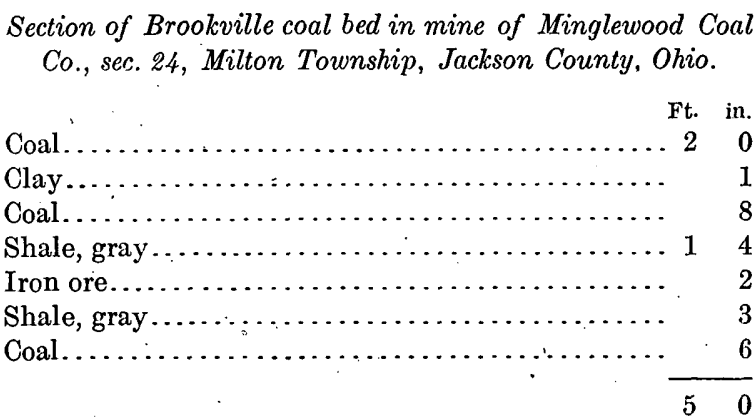

An analysis of the top layer of this coal shows 6.1 per cent of ash, 2 per cent of sulphur, and a heating value of $12,560 \mathrm{~B}$. t. u.

Farther south in Jackson County the coal bed thins and has little or no value. 
Lawrence County.-The coal is found in Lawrence County, but it is thin and has never been worked except in the smallest way.

\section{CLARION (NO. 4a) COAL BED.}

General features:-The Clarion (No. 4a) coal bed is easily recognized by its position under the Vanport or "Ferriferous" limestone, and for that reason it is often known as the "limestone coal." The coal is open burning, moderately hard, and in northern Ohio it is in places a cannel. It contains shale or clay impurities, and hence is high in ash; sulphur content also is large. However, the coal is suitable for steam and domestic purposes, and the day is not far distant when it will be eagerly sought. The coal bed in southern Ohio is nearly always divided into three benches by shale or clay partings whose thickness ranges from less than 1 inch to a foot. In northern Ohio it is a solid bed without definite partings.

Although the coal can be easily traced across the State, it is not of value except in the two opposite parts, northeastern Ohio and the extreme southern part of the State.

Columbiana County.-In Columbiana County the coal is mined in places. In the valley of North Fork of Little Beaver Creek, about a mile below Lisbon, the coal ranges from 2 feet 8 inches to 3 feet 4 inches in thickness, and contains some layers of shale or pyrite. It is used for domestic and steaming purposes. A dark brittle limestone, which lies 5 to 7 feet above the coal has been designated the "Ferriferous." The following is Orton's section, slightly changed, of the strata in the vicinity of Lisbon:

Section of the strata in the vicinity of Lisbon, Ohio.

Coal, Upper Freeport (No. 7) ............. Ft. in. 34

Clay.................................... 20

Limestone, Upper Freeport.................. 2 0

Unseen.................................. $23 \quad 0$

Sandstone........................... $20 \quad 0$

Coal, Lower Freeport (No. 6a)............... 10

Shale............................... 70

Limestone, Lower Freeport.................. 550

Sandstone, Freeport, and shale................. $50 \quad 0$

Coal, Middle Kittanning (No. 6) ..............

Sandstone.................................. $12 \quad 0$

Coal, Lower Kittanning (No. 5)............. 14

Shale................................ 370

Limestone, Vanport ("Ferriferous") .............. 3 \%

Coal, Clarion............................. 3 . 30

Clay................................. 4 . 6

Coal............................. $1 \quad 6$

$176 \quad 4$
The Clarion coal is mined in the northern part of Columbiana County and is shipped from the Delmore mine, $1 \frac{1}{2}$ miles west of Leetonia. The following section was measured in this mine:

Section of Clarion coal bed in Delmore mine, $1 \frac{1}{2}$ miles west of Leetonia, Ohio.

le. $\quad$ Ft. in.

Coal........................... 31

Shale, hard $\ldots \ldots \ldots \ldots \ldots \ldots \ldots \ldots \ldots \ldots \ldots$

Coal............................. 9

Clay $\ldots \ldots \ldots \ldots \ldots \ldots \ldots \ldots \ldots \ldots \ldots \ldots \ldots \ldots \ldots, 12 \quad 0$

$\begin{array}{ll}17 & 1\end{array}$

The coal has no regular partings, but shale and pyrite bands are not uncommon. The product of the mine is used largely for locomotives. The bench below the hard shale is not mined. It is reported to range from 6 to 12 inches in thickness but in places to be wanting. The Lower Kittanning or No. 5 coal was formerly mined in this vicinity.

The Clarion coal has long been mined in the vicinity of Canfield, Mahoning County, where it is a cannel and was formerly distilled for illuminating oil. Newberry says:

It is a very variable seam so far as regards thickness and character but is almost always present in one or another of its phases at the horizon where it belongs. In some localities it is 6 feet in thickness, all cannel coal of good quality; in others it is a remarkably pure bituminous coal $2 \frac{1}{2}$ to 3 feet thick, while more generally it is found to have a thickness of about 3 feet, of which 6 to 10 inches of the upper part is cannel.

This coal bed has never been mapped in Columbiana and Mahoning counties, but it appears to occupy a large area and may be looked on as a reserve that will be eagerly sought when the thicker coal beds are a thing of the past.

The Clarion coal can be followed in outcrop from Columbiana County southwest to Vinton, where it again attains workable thickness. Between these distant counties the coal rarely if ever measures 2 feet in thickness. and generally is represented by only a streak.

Lawrence County.-The one important field of the Clarion coal lies in Lawrence, Scioto, Jackson, and Vinton counties, where it is worked for railroad shipment as well as for local purposes. For many years the Wellston or Quakertown bed was mined because of its superior quality, and the Clarion bed was neglected, but the increasing demand for fuel and the scarcity of Wellston coal led to mining in the Clarion, which has now grown to considerable.importance. With the exhaustion of the 
better coal the Clarion will be more and more in demand.

The coal is above drainage in the western half of Lawrence County and is exposed in numerous places, especially in the northern part. The Vanport ("Ferriferous") limestone is well developed there, and by its aid the identification of the coal is easy.

Section of Clarion coal bed from mine of J. R. Edwards, sec. 23, Washington Township, Lawrence County, Ohio. [See fig. 11, B.]

Limestone, Vanport ("Ferriferous").

Coal, upper bench

Shale.....

Coal, middle bench

Shale. Clay.

Coal, lower bench

The section shows only 3 feet of coal, but others in the county (see fig. $11, A$ ) show as much as 4 feet 4 inches.

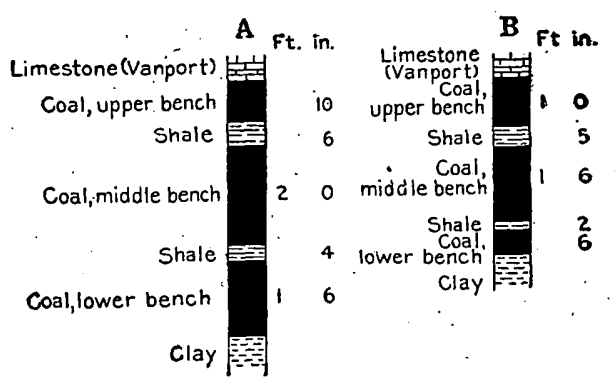

FIGURE 11.-Sections of Clarion (No. 4a) coal bed in Lawrence County, Ohio. A, Decatur Township; B, Washington Township.

The proximate analysis of a sample from this mine gives moisture 6.0, volatile matter 39.1, fixed carbon 43.0 , and ash 11.9 per cent. The ultimate analysis gives carbon 63.32 , hydrogen 5.26 , oxygen 13.24 , nitrogen 1.22 , sulphur 5.10, and ash 11.86 per cent. The heating value is 11,730 B. t. u.

Scioto County.--In Scioto County the Clarion coal is limited to Bloom Township and is worked for railroad shipment in a single mine. The coal is similar in all respects to that in Lawrence County:

Jackson County.-Dackson County contains a large area of Clarion coal in its eastern tier of townships, Madison, Bloomfield, and Milton, and in each of these the coal is mined for railroad shipment as well as for use by farmers.

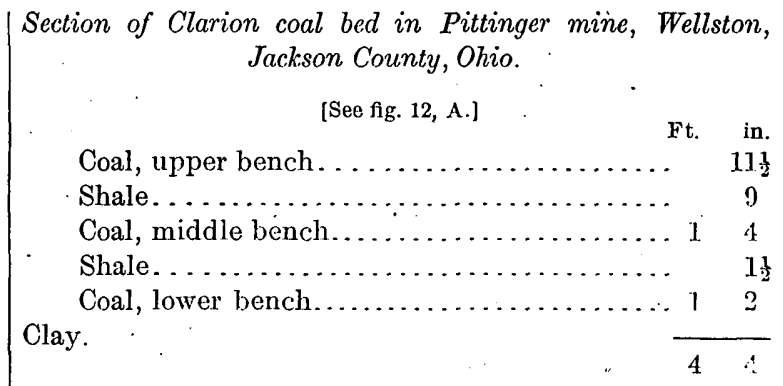

The proximate analysis of a sample from this mine shows moisture 5.3, volatile matter 41.0, fixed carbon 45.3 , and ash 8.4 per cent: An

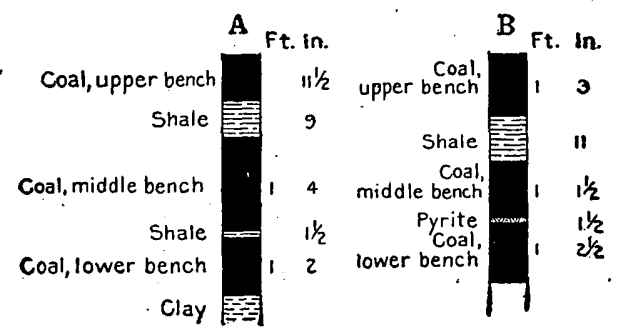

FIGURE 12.-Sections of Clarion (No. 4a) coal bed in Ohio. A, Wellston, Jackson County; B, Wilkesville, Vinton County.

ultimate analysis of the same sample gave carbon 66.52 , hydrogen 5.50 , oxygen 14.58 , nitrogen-1.28, sulphur 3.72 , and ash 8.40 per cent. The heating value is 12,290 .B. t. $u$.

Vinton County.--Vinton County is the third source of Clarion coal, but the known workable areas are restricted to Wilkesville and Vinton townships, where it is mined and shipped on the Hocking Valley Railway. The limestone and coal are well exposed along Raccoon Creek, but east of this stream the coal in a short distance dips below drainage level.

Section of Clarion coal bed in Lawler mine, Minerton, Vinton County, Ohio.

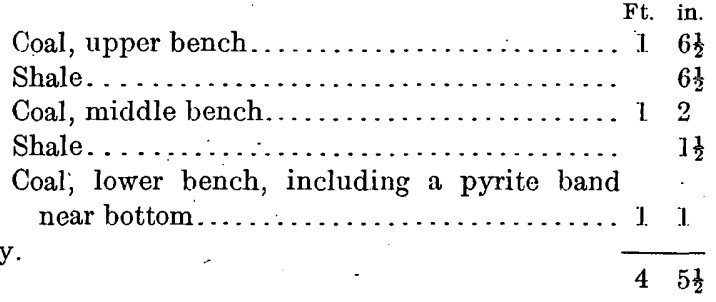

The proximate analysis of a sample from this mine shows moisture 4.5, volatile matter 40.1, fixed carbon 46.5 , and ash 8.9 per cent; the ultimate analysis shows carbon 67.17 , hydrogen 5.44 , oxygen 13.03 , nitrogen 1.28 , sulphur 4.23 , 
and ash 8.85 per cent. The heating value is 12,430 B. t. u. The character of the coal bed at Wilkesville is shown by figure $12, \mathrm{~B}$.

LOWER KITTANNING (NO. 5) COAL BED.

General features.-The Lower Kittanning (No. 5) coal bed may readily be traced across the State from Columbiana County to Lawrence County. However, it is not everywhere of minable thickness according to present standards, and in fact is not now one of the largest sources of coal in Ohio. The general group of beds of which it is a part is one of great value, for a short distance below it lies the Vanport or "Ferriferous" limestone and ore, the former used in making : Portland cement and the latter a source of iron for blast furnaces years ago. More important by far, however, than these is the great bed of clay that directly underlies the coal and that is so extensively used in the clay industries of eastern Ohio. $\Lambda$ bout 25 feet above the Lower Kittanning coal lies the Middle Kittanning bed, and this is one of the two most important coals in Ohio, its only rival being the Pittsburgh bed. Between the two Kittanning coal beds there is found in places a bed of clay or shale that is suitable for the manufacture of clay wares. The sequence of these beds is as follows:

General sequence of the Middle and Lower Kittanning coal beds and underlying strata in Olio.

Middle Kittanning (No. 6) coal.

Middle Kittanning clay.

Shale or sandstione.

Lower Kittanning (No. 5) coal.

Lower Kittanning clay.

"Ferriferous" iron ore.

Vanport ("Ferriferous") limestone.

Columbiana County.-The Lower Kittanning coal was formerly mined in a large way at Leetonia, Columbiana County; and was used for making coke for local blast furnaces. The following is Orton's section and comment on the coal at this place:

Section of Lower Kittanning coal bed at Leetonia, Ohio.

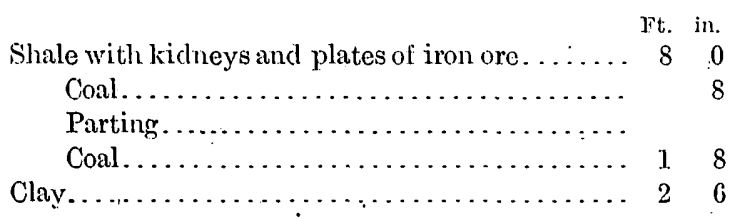

12 The proximate analysis of a sample from
The coal is found in two benches, the lower of which is much the purer. The upper bench often becomes slaty and cannel-like, and must then be rejected. The bottom coal, which is also called the Smith coal, is a cementing coal of pronounced character, but the upper bench never has this quality. *** The bottom coal is also an exceptionally good fuel for rolling mill use. It burns with a bright blaze and gives out its heat quickly.

The area of the Leetonia field is small and the coal has not been mined for years except locally for domestic purposes. When the field was visited in $1915^{\circ}$ not a mine was in operation, though one was being opened for local use near Washingtonville, where the section given in figure $13, \mathrm{~A}$, was measured.
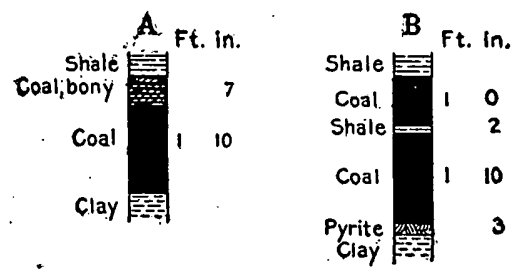

Figure 13.-Sections of Lower Kittanning (No. 5) coal bed in Ohio. A, Washingtonville, Columbiana County; B, Pike Townshtp, Stark County.

Carroll, Stark, and Tuscarawas counties.From Columbiana County the Lower Kittanning coal can be followed southwest through. Stark and Carroll counties into the adjacent corner of Tuscarawas County. In Pike Township, Stark County, it has the thickness and character shown in figure $13, \mathrm{~B}$. It is worked along Big Sandy Creek in the northwest corner of Carroll County, and it constitutes the well-known Mineral City bed in Tuscarawas County.

Section of Lower Kittanning coal bed from Huff Run mine No. 1, Mineral City, Ohio.

[Sce fig. 14, A.]

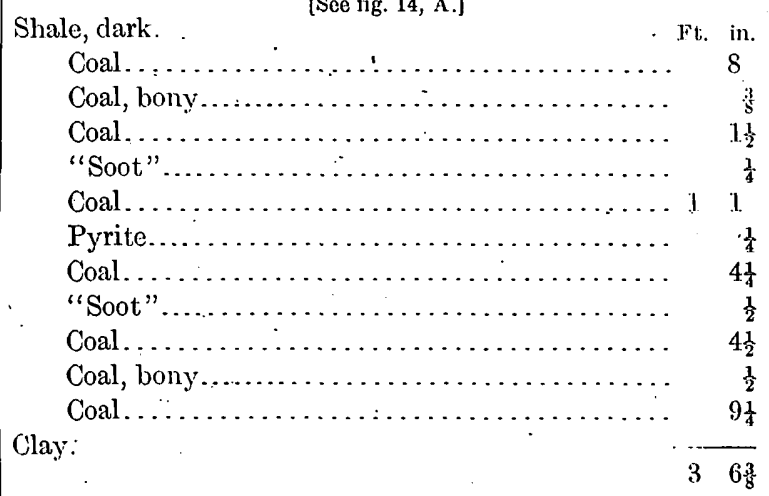

The proximate analysis of a sample from this mine gave moisture 5.3 , volatile matter 
38.7, fixed carbon 48.3 , and ash 7.7 per cent; the ultimate analysis gave carbon 69.75, hydrogen 5.46 , oxygen 12.65 , nitrogen 1.18 , sulphur 3.25 , and ash 7.71 per cent. The heating value is $12,900 \mathrm{~B}$. t. u.

The rocks in the vicinity of Mineral City have been disturbed by crustal movements and form a prominent syncline, which of course has its effect on mining. Orton says: "There is no known portion of the coal field of Ohio where there has been a tithe of the disturbance that occurs in the vicinity of Mineral Point [Mineral City]."

The coal is mined by stripping for railroad shipment on the Hagg farm in Sandy Township, $2 \frac{1}{2}$ miles east of Sandyville, where the thickness ranges from 4 to 5 feet and the structure of the bed is similar to that recorded in the preceding. section. The coal in this part of Tuscarawas County manifestly contains some impurity, but its heating value is good, and it ranks well as a steam producer. It is extensively used in burning clay wares. From Sandy Township the Lower Kittanning coal can be followed southwest across the county. It has been mined in both large and small ways between Mineral City and Canal Dover, but southwest from Canal Dover it is thin and has little value. The coal is of little or no importance in Holmes and Coshocton counties.

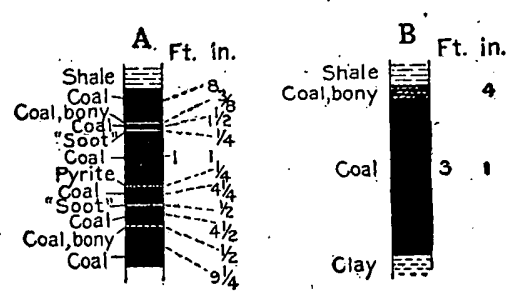

Figure 14.-Sections of Lower Kittanning (No. 5) coal bed in Ohio. , A, Mineral City, 'Tuscarawas County; B, Toronto, Jefferson County.

The lower Kittanning coal is also mined in a small way in the bluft's of Ohio River in Jefferson County. A section of the bed at Toronto is represented in figure $14, \mathrm{~B}$.

Guernsey County.-In Guernsey County the Lower Kittanning coal is found in the valley of Wills Creek for several miles south of Kimbolton and is reported to have a thickness as great as 4 feet 9 inches.

Muskingum County.-The Lower Kittanning coal is not of great importance in Muskingum County and as far as now known is of workable thickness in only two areas, the vicinity of
Zànesville and Newton Township. The Zanesville area is small and the coal is known as the "4-foot bed." It has long been used at Zanesville for domestic and other purposes and is rated as a good fuel.

Section of Lower Kittanning coal bed in old Harper mine near Zanesville, Ohio.

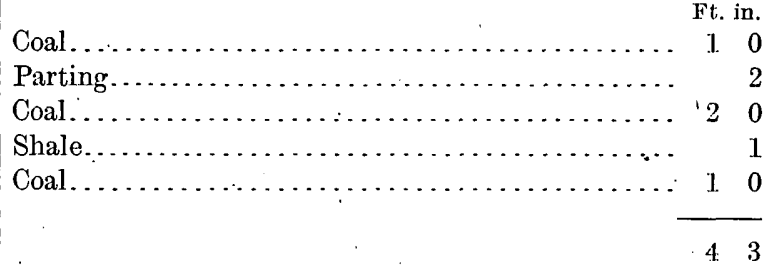

Newton Township forms the southwestern corner of Muskingum County, and the Lower Kittanning coal is there of importance.

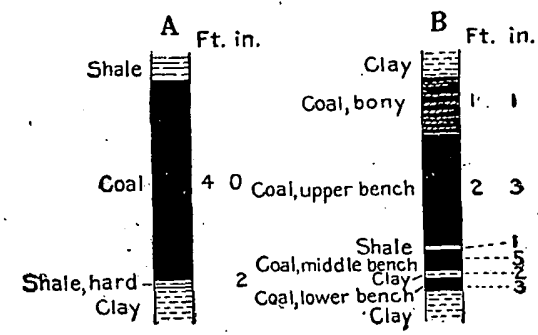

Figure 15.-Sections of Lower Kittanning (No. 5) coal bed in Ohio. A, Redfield, Perry County; B, Milton Township, Jackson County.

Perry County.-The coal extends from Muskingum into northeastern Perry County, where it is mined at Redfield (fig. 15, A) and a mile or two east of New Lexington for railroad shipment and for local use, and is locally known as the Lower New Lexington or 4-foot bed. The coal in places is without partings and may be free from dirt, but the floor rises and falls, causing the thickness of the bed to vary.

Section of Lower Kittanning coal bed in Copelin mine, sec. 2, Pike Township, Perry County, Ohio.

Shale.

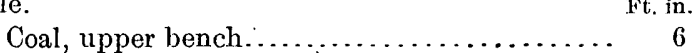

Coal, horn ${ }^{1} \ldots \ldots \ldots \ldots \ldots \ldots \ldots \ldots \ldots \ldots . \quad 1$

Coal, middle bench..................... 10

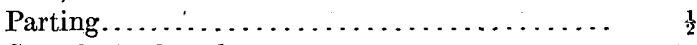

Coal, lower bench.................... 19 Clay.

$\overline{34 \frac{1}{2}}$

The proximate analysis of a sample from this mine gave moisture 6.8 , volatile matter 35.2 , fixed carbon 47.8 , and ash 10.2 per cent; an ultimate analysis gave carbon 64.78 ,

1 The term "horn coal" here means an impure cannel but is used by some to designate any lean, impure coal or bone. 
hydrogen 5.26 , oxygen 13.86 , nitrogen 1.22 , sulphur 4.72 , and ash 10.16 per cent. The heating value is $11,860 \mathrm{~B}$. t. $\mathrm{u}$.

The coal underlies the southern townships of the county and has been mined for local use a.t several places. Perry County contains a large acreage of the Lower Kittanning coal of suitable thickness and quality for mining in a large way, but its development has been retarded by the presence of the Middle Kittanning bed, which is thicker and generally more desirable.

Hocking, Vinton, and Jackson counties.The Lower Kittanning coal is thinner and of smaller value in Hocking County and still less so in Vinton County, but it thickens in eastern Jackson County, where it is mined in a small

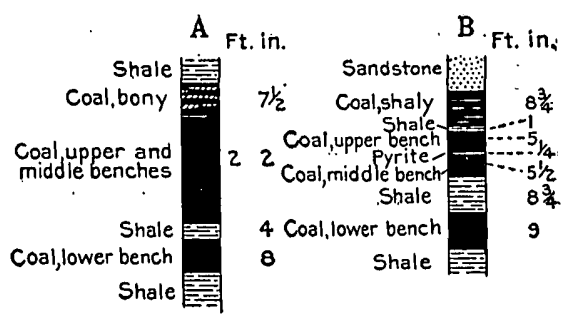

Fraure 16.-Sections of Lower Kittanning. (No. 5) coal bed in Lawrence County, Ohio. A, Etna, Elizabeth Township; B, Coalgrove, Perry 'T'ownship.

way for railroad shipment. The bed is irregular but ranges from 3 to 4 feet in thickness over hundreds, perhaps thousands of acres. A section of the coal bed in Milton Township is represented in figure $15, \mathrm{~B}$.

Lawrence County.-The coal is still more valuable in Lawrence County, across which it can be readily traced to Ohio River, in whose bluff it is mined at Coalgrove. A section of the coal bed at this place is shown in figure $16, \mathrm{~B}$. It is worked in Washington, Decatur, Elizabeth, Upper, and Perry townships. It is rated at its best in Elizabeth Township.

Section of Lower Kittanning coal in Hocking Coal Co.'s mine No. 2, Etna station, Elizabeth Township, Lawrence County, Ohio.

Shale.

[See fig. 16, A.]

Coal, bony.

Coal, upper and middle benches

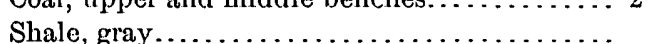
Shale.

Coal, lower bench..................... 8

$\cdot \overline{39 \frac{1}{2}}$
The proximate analysis of a sample from this mine shows moisture 8.1, volatile matter 34.5 , fixed carbon 47.7 , and ash 9.7 per cent; an ultimate analysis gives carbon 65.54 , hỳdrogen 5.44 , oxygen 15.95 , nitrogen 1.23 , sulphur 2.13, and ash 9.71 per cent. The heat value is $11,930 \mathrm{~B}$. t. $\mathrm{u}$.

The coal is open burning, rather soft, moderate in ash and sulphur. It makes a fair coke . but is not used for that purpose. It is well adapted for steam and domestic uses and is the main reliance of the city of Ironton. The field is the most valuable one of this bed in Ohio, and the coal is extensively mined for railroad shipment.

\section{MIDDLE RITTANNING (NO. 6) COAL BED.}

The Middle Kittanning (No. 6) coal, on account of its quantity and quality, is the most valuable in Ohio. It is found along the State line in Columbiana County and can not only be followed with ease across the State to Lawrence County on Ohio River but it is workable in every county where it should appear above drainage and in most of them on a lairge scale. The bed lies 20 to 35 feet above the Lower Kittanning coal and is generally easily identified.

Columbiana County.-The Middle Kittanning cóal underlies much of the eastern and southern parts of Columbiana County, and its relations to lower beds are well shown in the following section measured by Orton:

Section at Robbinsville, Ohio. rt. in.

Sandstone, Freeport ("Lower Freeport") .......... 200 Coal, Middle Kittanning (No. 6)............. 8

Sandstone and shale...................... $15 \quad 0$ Coal, Lower Kittanning (No. 5) .............. 14

Shale and ore nodules.................... $40 \quad 0$

"Draw slate"............................ 10 Coal, Clarion (No. 4a) ................. 30

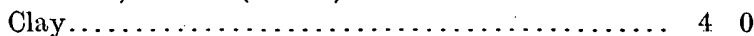
Coal...................... 8

86.8

The coal bed in Columbiana County is less than 3 feet thick and has not been worked in a large way, but it has been mined for local use in Dry Run near East Liverpool. The coal is clean, of good quality, mines with much lump, and has an excellent reputation. 
Section of Middle Kittanning coal bed at mouth of Dry Run, Columbiana County, Ohio.

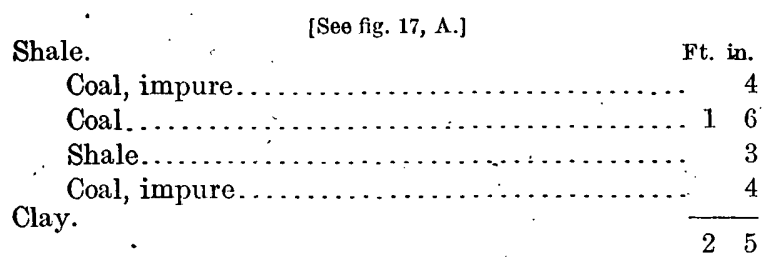

A sample taken at this place showed 4.6 per cent ash, 1.76 per cent sulphur, and has a heating value of 14,020 B. t. u., which compares favorably with that of the best coals mined in Ohio.

Along Yellow Creek in the southern part of the county the Middle Kittanning coal has also been mined and is there known as the Hammondsville strip vein. It is thin and can not compete with large beds.

Stark County.-The Middle Kittanning coal extends from Columbiana County west into

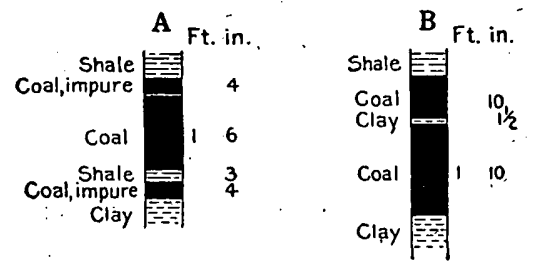

Fravre 17.-Sections of Middle Kittanning (No. 6) coal bed in Ohio. A, Eașt Liverpool, Columbiana County; B, Nimishillen Township, Stark County.

Stark, where it has workable thickness in the eastern and southern townships. At Waynesburg, in the southeast corner of Sandy Township, the bed has the following structure:

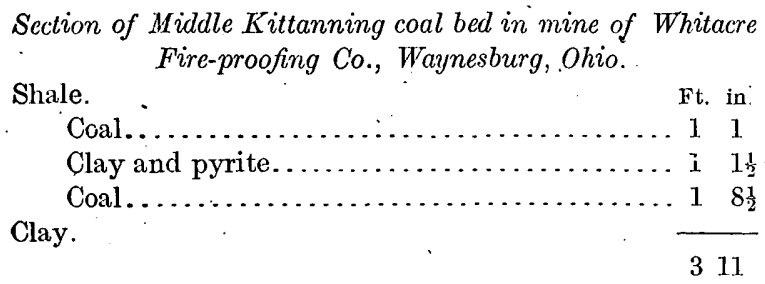

A sample taken at this place showed 8.2 per cent ash, 2.66 per cent sulphur, and a heating value of 12,560 B. t. $u$. The coal is mined for railroad shipment in Osnaburg Township and was formerly worked on this scale in the Nimishillen Valley, south of Canton, where the bed ranges from 2 to 3 feet in thickness and is divided into two benches by a clay or shale parting about 2 inches thick, as shown in figure $17, \mathrm{~B}$, which is a section of this bed measured in Nimishillen Township. The area of Middle
Kittanning coal in Stark County is large, and in the not distant future the coal will be extensively mined.

Carroll County.-In Carroll County, which lies south of Columbiana and Stark counties, the Middle Kittanning coal is above drainage in Rose and Brown townships, where it has long been mined in a small way but does not appear to be of great value.

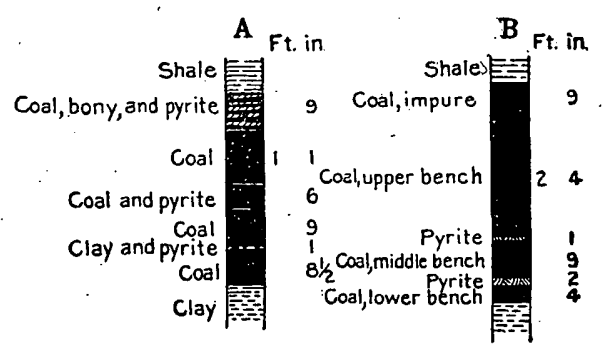

Figure 18.-Sections of Middle Kittanning (No. 6) coal bed in Tusca rawas County, Ohio. A, Somerdale, Fairfield Township; B, Gnadenhutten, Clay Township.

Tuscarawas County.-Tuscarawas County, one of the large coal-producing counties of Ohio, derives probably 90 per cent of its fuel from the Middle Kittanning bed. The mines, which are not evenly distributed, are grouped in four districts-Valley Junction, east of New Philadelphia, south of New Philadelphia, and Uhrichsville. However, the Middle Kittanning coal bed is not restricted to these districts, but is found in every township in the county and has

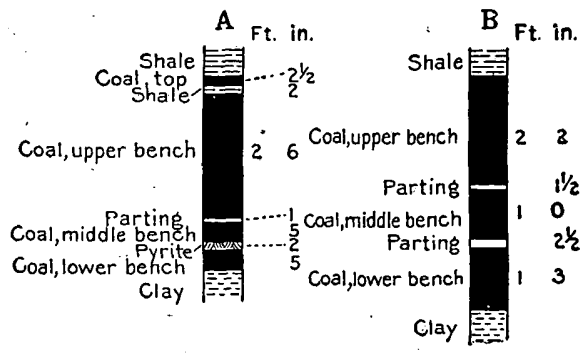

FIgURE 19.-Sections of Middle Kittanning (No. 6) coal bed in Tuscarawas County, Ohio. A, Auburn Township; B, Goshen Township.

been mined in all except Perry. In the northwestern part of the county, however, it lies so near the hilltops that its area is small. Moreover, it is thin in that region, generally not exceeding 3 feet; whereas in those parts where it is most extensively mined it is 3 feet 6 inches to 5 feet thick, and, according to Orton, is of superior quality. The coal, which in Stark County consists of two benches, consists of three in most places in Tuscarawas County. The character of the Middle Kittanning coal bed in this county is represented by figures 18 and 19 . 
Section of Middle Kittanning coal from Medville \& Goshen Coal Co.'s mine, Warwick Township, Tuscarawas County, Ohio.

Shale.

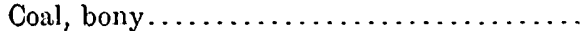

Coal, upper bench.......................

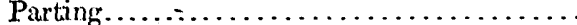

Coal, middle bench...................

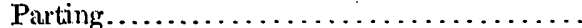
Clay.

Coal. lower bench....................

Ft. in.

9

19

$\frac{1}{2}$

7

A sample obtained in this mine, upon analysis, shows moisture 4.1, volatile matter 41.6, fixed carbon 49.1, and ash 5.2 per cent. Its ultimate analysis shows carbon 72.45 , hydrogen 5.57 , oxygen 12.10 , nitrogen 1.42 , sulphur 3.25 , and ash 5.21 per cent. The heat value is 13,200 B. t. u. An average of 16 samples from various parts of the county shows thickness 3 feet 7 inches, ash 7.3, moisture 4.3, sulphur 3.85 per cent, and heat value 12,800 B. t. u.

The Middle Kittanning coal in Tuscarawas County has moderate strength and is suitable for domestic use, but its great market is for steam production. The quantity of the coal is large, and the county will be an important source of fuel for many years.

Coshocton County.-Coshocton County, which lies southwest of Tuscarawas, contains a large

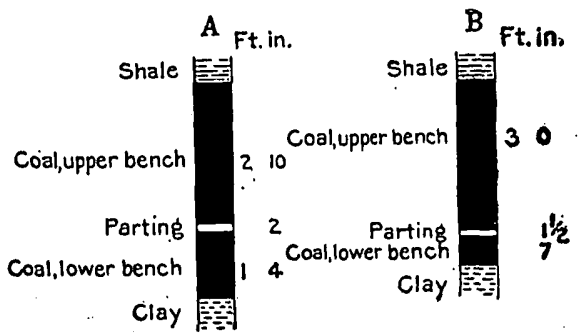

Fiaure 20.-Dections of Middle Kittanning (No. 6) coal bed in Coshocton County, Ohio. A, Franklin Township; B, Virginia Township.

area of the Middle Kittanning coal in the southeastern part. The coal is extensively worked for railroad shipment near Muskingum River below Coshocton and southeast of that town in Lafayette Township. The coal in the southern part of the county consists generally of two benches with a parting near the bottom ranging from 1 inch to 2 inches in thickness, as shown in figure $20, \mathrm{~A}$ and $\mathrm{B}$, and figure 21, A. In the northern part of the county it is in places free from partings, as shown in figure $21, \mathrm{~B}$.
An average of 11 samples from various parts of the county shows thickness 3 feet 2 inches, ash 6.8 , moisture 5.5, sulphur 3.82 , and heat value 12,560 B. t. $u$. These figures show that the coal is similar to that of the same bed in Tuscarawas County. Incidentally, the coal is used for the same purposes.

Guernsey County.-The coal is mined for railroad shipment in the northwest corner of

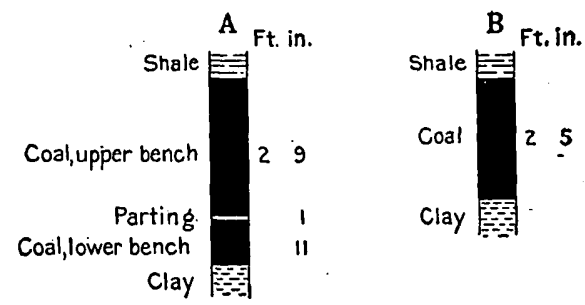

Figure 21.-Sections of Middle Kittanning (No, 6) coal bed in Coshocton County, Ohio. A, Jackson Township; B, Clark Township.

Guernsey County and also a short distance north of the county seat, Cambridge.

Muskingum County.-The Middle Kittanning coal underlies. nearly the whole of Muskingum County east of Muskingum River and parts of Harrison, Brush Creek, Newton, and Perry townships west of the river. Its area is therefore large. However, it passes below drainage in Rich Hill, Union, and southern Highland townships, and very little is known of it in that territory. It is mined for local use in every township where it should appear above drainage and for railroad shipment on the west side of Muskingum River.

Orton says:

The seam falls short of 3 feet in parts of the field, and it nowhere yields fully 4 feet of coal, but it holds, with surprising steadiness, a measure ranging from 30 to 42 inches of coal. Its structure, too, is maintained with great regularity over large areas.

The coal bed, as shown by the following section, consists of two benches separated by a thin layer of shale or clay:

Section of Middle Kittanning coal bed in Birkhimer mine, Madison Township, northern Muskingum County, Ohio.

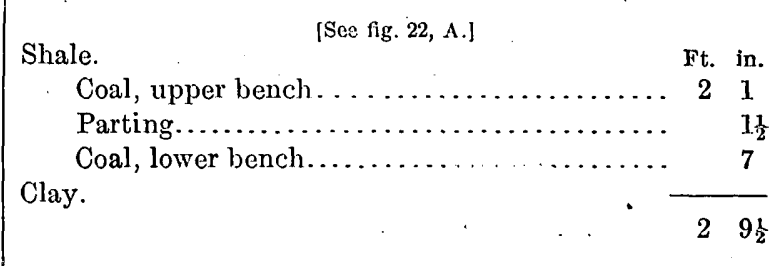


Section, of Middle Kittanning coal bed in Walnut Hill Coal Co.'s mine; sec. 13, Brush Creek Township, Muskingum Cónity, Ohio:

$\because \because:$

Shale. Ft. in.

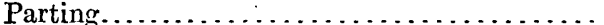
Clay.

Coal, lower bench..................... 20

$237 \frac{1}{2}$

A sample obtained in this mine gave, in proximate analysis, moisture 5.1, volatile matter 39.7 , fixed carbon 45.4 , and ash 9.8 per cent;

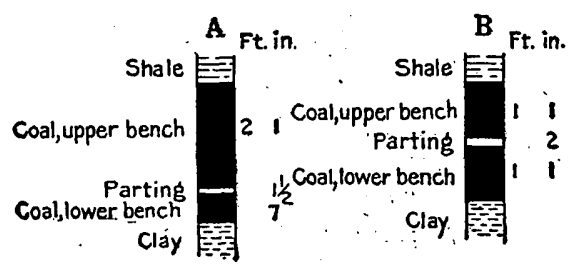

Fiaure 22.-Sections of Middle Kittanning (No.6) coal bed in Muskingum County, Ohio. A, Madison Township; B, Harrison Township.

and in ultimate analysis carbon 65.74 , hydrogen 5.32, oxygen 12.49 , nitrogen 1.14 , sulphur 5.54 , and ash 9.77 per cent. The heat value is 12,240 B. t. u. Figure 22, B, shows the character of the bed in Harrison Township.

Perry County.-The Middle Kittanning coal is found wherever due in the eastern half of Perry County, and in normal structure and thickness except in the southern tier of townships, where it thickens and forms part of the Hocking Valley coal field. The structure and thickness of the bed in the northern part of the rounty are shown in figure $23, \mathrm{~A}$, and in the central part in figure 23, B. North of these southern townships its area is large and its thickness, structure, and quality are similar to those prevailing in Muskingum County. Throughout this area the coal is extensively mined for railroad shipment as well as for local use.

The thickness and quality of the coal between Muskingum River and the Hocking Valley field are well shown in the following average of 10 measurements and samples: Thickness 3 feet 4 inches, ash 8.4 , moisture 5.9 , sulphur 3.72 per cent, and heat value 12,310 B. t. u.

Hocking Valley field.-The Hocking Valley coal field, as outlined by Orton, consisted of those parts of Perry, Hocking, and Athens counties where the Middle Kittanning bed is 5 feet or more in thickness. This includes parts of Coal, Salt Lick, and Monroe townships,
Perry County; parts of Ward, Green, and Starr townships, Hocking County; and parts of Trimble, Dover, York, Waterloo, Athens, and Canaan townships, Athens County. Orton computed the area of the field at about 94,000 acres. Recent drilling by F. A. Ray has brought to light much additional information regarding this coal bed and has materially changed Orton's southern limit, which is now placed approximately 2 miles south of Athens and 1 mile south of New Marshfield and Mineral, and his western limit, which is now placed near the outcrop of the coal. It must not be understood, however, that within these boundaries the coal everywhere equals or approaches 5 feet in thickness, for in many places it is less and in large areas it is cut out entirely. The greatest change is along the eastern border, which is marked by the "faulted" or barren area that in the main lies just east of the valley of Sunday Creek. The map (Pl. III) by F. A. Ray shows for the first time the Jumbo "fault," which is not a fault at all in the technical sense but an area where the coal is cut out by sandstone or other rock. The cutting appears to have been the work of streams whose current

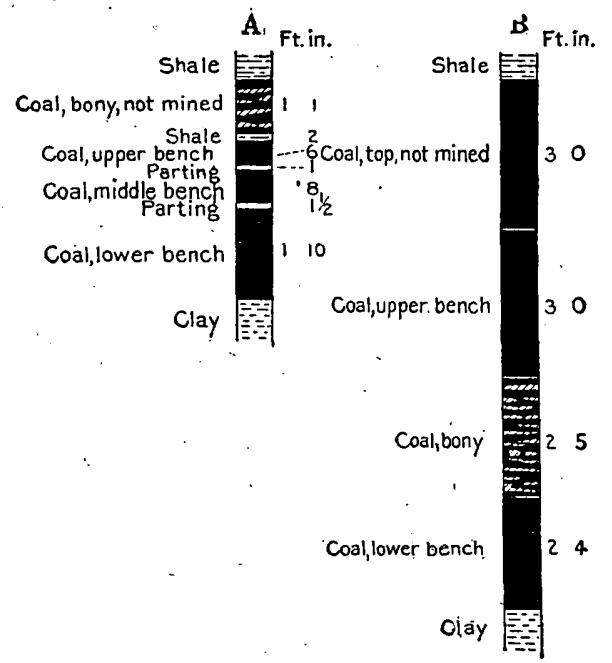

Figure 23.-Sections of Middle Kittanning (No. 6) coal bed in Perry County, Ohio. A, Harrison Township; B, Pike Township.

swept away the accumulated vegetal material and deposited in its place sand or mud. Lack of definite knowledge as to the location and extent of this "fault" has caused heavy financial losses to mining companies.

The coal comes in again just east of the fault in Homer, Union, and Marion townships, but it is thin in this area, which is not generally regarded as a part of the Hocking Valley field. 


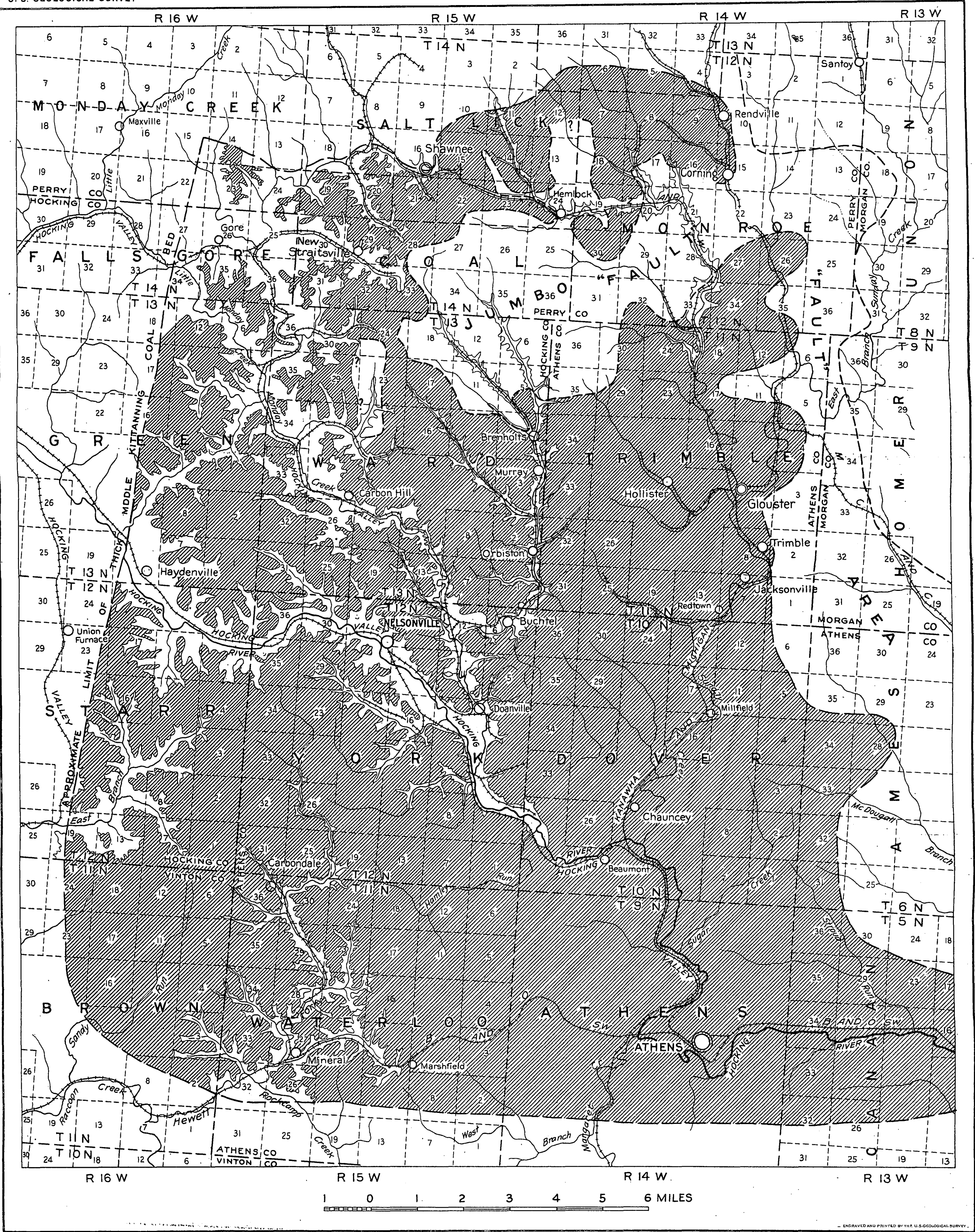

MAP OF THE HOCKING VALLEY COAL FIELD (MIDDLE KITTANNING OR NO. 6 COAL BED), SOUTHEASTERN OHIO 
Section showing relations of Middle Kittanning coal to strata above and below, in Focking Valley coal field, Ohio.

Timestone Cambridge $\ldots \ldots \ldots \ldots \ldots$ Feet

Shale................................... 29

Brush Creek shale member:

Limestone.

Limestone............................ 1

Sandstone, shaly......................... 30 Coal, Mahoning, thin.

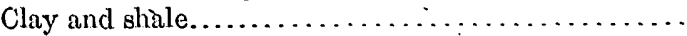

Sandstone, Mahoning.

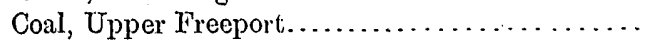

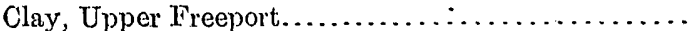

Limestone (Upper Freeport), ore; sandstone, and shale. Coal, Lower Treeport:

Clay, limestone (Lower Freeport), and sandstone (Free-

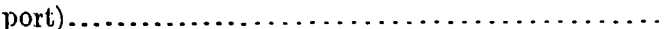

Coal, Middle Kittanning. . . . . . . . . . . . . . . .

Clay, shale, and ore......................... 30

Coal, Lower Kittanning................... 2

Clay and shale........................... 15

Limestone, Vanport ("Ferriferous").

Concerning the structure of the coal bed in this field Orton says:

In structure, the Hocking Valley coal always has the three benches of the normal Middle Kittanning seam, with

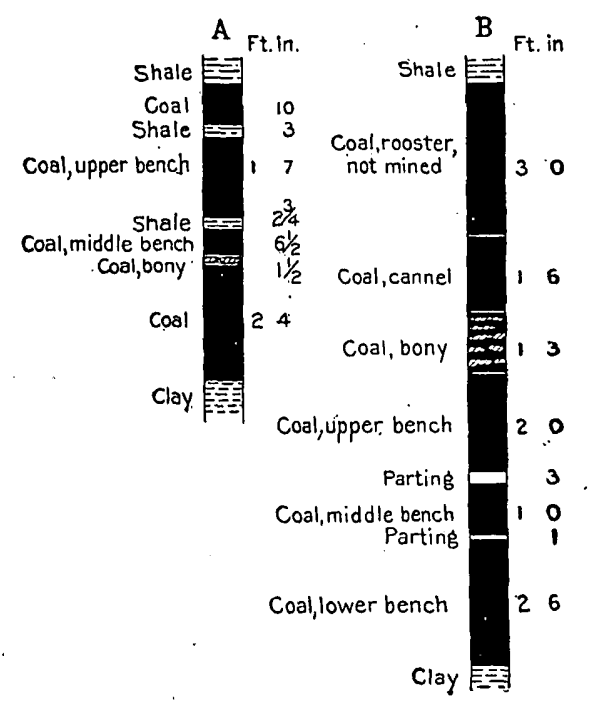

Figure 24.-Sections of Middle Kittanning (No. 6) coal bed in Athen County, Ohio. A, Canaanville; B, Trimble Township.

some addition of its own. In other words, the Great vein consists of the normal, three-bench seam of Middle Kittanning age, covered and reinforced by a Hocking Valley supplementary seam, the latter consisting of one or two or more benches. The supplementary seam is separated from the original seam by a thin shale parting, which is often disregarded in mining, but which is for the most part distinctly recognizable when looked for.
This "supplementary seam" is known among engineers and miners as the roof or "Rooster" coal. Early efforts in the northern part of the field to market it were failures but later trials were more successful. 'The coal is very high in ash, but is said to have good heating value and to be easily ignited. Moreover it stands transportation unusually well, and this and its

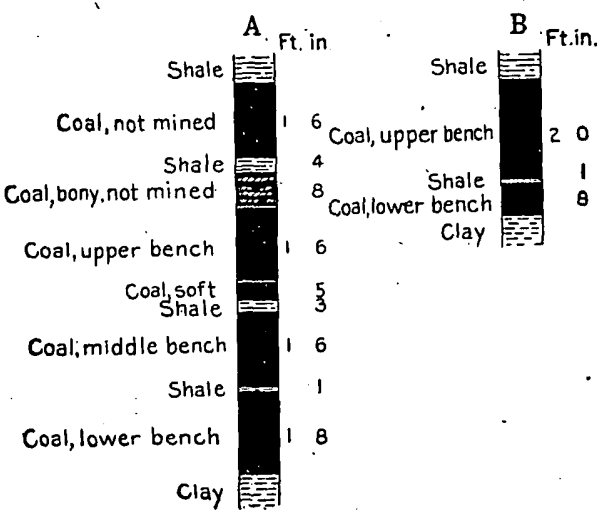

Frgure 25.-Sections of Middlo Kittanning (No. 6) coal bed in $\Lambda$ thens County, Ohio. A, Dover Township; B, Waterloo Township.

ease of ignition has secured for it a market for domestic purposes in the Northwest. However, this part of the bed has never been successfully mined except in the vicinity of Corning, Rendville, Congo, Shawnee, and New Straitsville, all in the northern part of the Hocking Valley field. Farther south the "supplementary seam" has more shale and can not be marketed. The coal bed as a whole is thickest in southern Perry County, where, it measures locally as much as 15 feet.

The character and thickness of the Middle Kittanning coal bed in Athens County is shown in figures 24 and 25 and by the following sections. The first is from the Sunday Creek Valley and the second from the western side of the field.

Section of Middle Kittanning coal bed in mine of Continental Coal Co., sec. 8, Trimble Township, Athens. County, Ohio.

Shale.

Ft. in.

Coal, bony........................ $\quad \begin{array}{ll}4 & 6 \\ & 3\end{array}$

Coal, upper bench..................... $2 \quad 0$

Shale parting..........................

Coal, middle bench.................. I 0

Shale parting.................

Coal, lower bench..................... $\quad 2 \quad 6$ Clay.

117 
The proximate analysis of a sample from this mine shows moisture 7.3, volatile matter 32.4 , fixed carbon 53.6, and ash 6.7 per cent; the ultimate analysis shows carbon 69.46 , hydrogen 5.45 , oxygen 16.16 , nitrogen 1.34 , sulphur 0.86 , and ash 6.73 per cent. The heat value is 12,410 B.t. u.

Section of Middle Kittanning coal bed in mine of Continental Coal Co., sec. \& or 5, Ward Township, Hocking County, Ohio.

Shale:

Parting.

Coal, top bench....................... 3

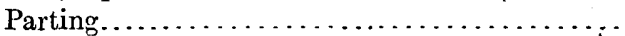

Coal, middle bench.................... 15

Parting................................ 1

Clay. .

Coal, lower bench...................... 1

A proximate analysis of a sample from this mine shows moisture 7.6, volatile matter 34.0, fixed carbon 52.6; and ash 5.8 per cent; and an ultimate analysis shows carbon 70.05 , hydrogen 5.52 , oxygen 16.39 , nitrogen 1.42 , sulphur 0.77 , and ash 5.85 per cent. The heat value is $12,510 \mathrm{~B}$. t. u. The character of the coal bed in Hocking County is shown in figure 26, A.

The composition of the coal is shown by the following average of 8 analyses of samples from various parts of the Hocking Valley field to be ash 6.2, moisture 7.3, and sulphur 1.22 per cent. The heating value is $12,500 \mathrm{~B}$. t. u.

These figures show but little difference in composition from that of the coal in Coshocton, Tuscarawas, Muskingum, and northern Perry counties, and in fact regularity in composition is one of the characteristics of the bed. The coal of the Hocking Valley field is open burning, low in sulphur, and moderate in ash. It was formerly used in the raw state in making pig iron; but that practice was long ago discontinued. The fuel has had a large sale for domestic purposes, but the great demand has always been for steam production. The coal is fairly hard and tough and so stands transportation relatively well. This quality has won for it a good market in the Northwest.

In early days coal was shipped north from this field by canal, but the quantity was relatively small. In 1869 the Hocking Valley Railway was completed to Columbus and in 1880 the Toledo \& Ohio Central Railway.
These lines gave a good outlet to Columbus, where connections were made with other roads. When, a few years later, these lines were extended to Toledo the market was greatly expanded and the Hocking Valley field became one of the largest producers in this country. The figures below show the production of Perry, Hocking, and Athens counties, and that of the Hocking Valley field would not be notably smaller.

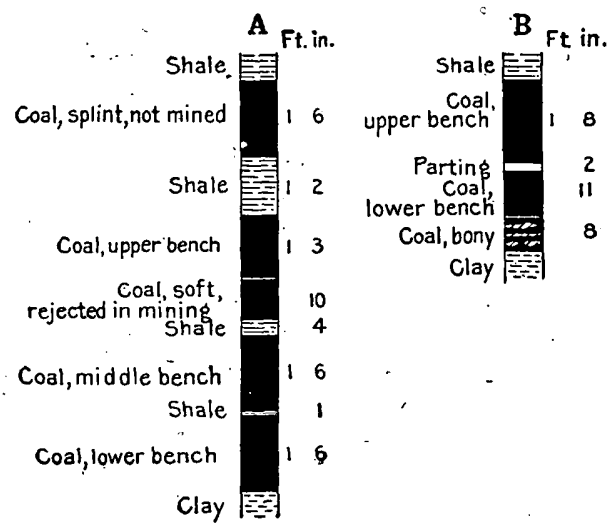

Fugure 26.-Sections of Middle Kittanning (No. 6) coal bed in Ohio. A, Ward Township, Hocking County; B, Swan Township, Vinton County.

Coal production for certain years of Perry, Hocking, and Athens counties, in short tons.

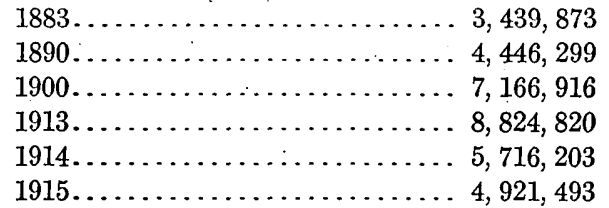

The zenith of the field's prosperity has been passed, though it will be a large producer for perhaps another half century. Within the last 15 years extensive efforts with the drill have been made to find new areas of coal under cover to the east and south, but the results have not been wholly successful. The best area discovered by this work is at Canaanville, 6 miles east of Athens, where the coal, found at a depth of 412 feet, is about 5 feet thick and has the normal structure and composition of the bed in the Hocking Valley field. It appears to be a lens-shaped block of coal and not a continuous bed, and other areas that have been discovered thus far also seem to lack continuity.

The Middle Kittanning coal extends southwest from the Hocking Valley field and is mined for railroad shipment in the triangle formed by Hocking River on the north, the 
Baltimore \& Ohio Railroad on the south, and the western boundary of Athens County. In places in the northern part of this area the coal bed has the same thickness and structure that it has in the Hocking Valley field, but elsewhere it is thinner and has only two or three benches. In other words, the "supplementary" bench is not present.

Vinton County.-The Middle Kittanning coal underlies a large part of the eastern half of Vinton County and has been mined for railrond shipment at widely different points, Moonville near the Athens County line, Zaleski, and north of McArthur. The thickness and structure of the bed in this county are well shown in the following sections:

Section of Middle Kittanning coal bed at Moonville, Ohio.

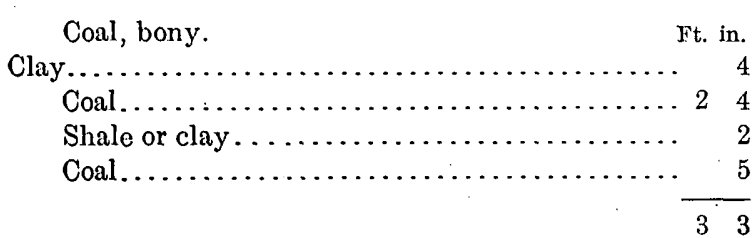

Section of Middle Kittanning coal bed in Cherry mine, sec. 3 , Swan Township, Vinton County, Ohio.

Shale.

[See fig. 26, B.]

Coal, upper bench................ $8 \ldots \ldots \ldots \ldots$

Parting............................... 2

Coal, lower bench......................... 11

Coal, bony $\ldots \ldots \ldots \ldots \ldots \ldots, \ldots \ldots \ldots \ldots, \quad 8$

A proximate analysis of a sample of cos from this mine shows moisture 4.9 , volatile matter 39.2 , fixed carbon 45.8 , and ash 10.1 per cent; an ultimate analysis shows carbon 66.26 , hydrogen 5.40 , oxygen 12.71 , nitrogen 1.23 , sulphur 4.25 , and ash 10.15 per cent. The heat value is 12,320 B. t. u. Although the heat value of this coal is fairly good, its percentages of ash and sulphur are high.

Section of Middle Kittanning coal bed on the Baltimore \& Ohio Railroad at Zaleski, Ohio

" Ft. in.

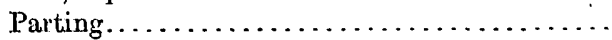

Coal, middle bench.................... 1.

Parting................................... .

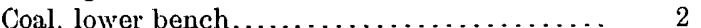

38

The coal is thin in the southern part of Vinton County and is not mined for shipment, but near Hamden it is worked for burning brick.
Jackson, Gallia, and Lawrence counties.-The Middle Kittanning coal is found well up in the. hills in the eastern tier of townships in Jackson County, where it usually ranges from 18 to 24 inches in thickness. It crosses Greenfield Township of Gallia County, where it has the character shown in figure $27, \mathrm{~A}$. It can be readily traced across Lawrence County, though it is too thin to be of much value. It outcrops along Symmes Creek and its western tributaries, but it exceeds 2 feet 6 inches in thickness in few places. It has long been mined for local use at Sheridan on Ohio River, where it measures 2 feet 10 inches to 4 feet and is without partings. A section of the coal bed in this locality is shown in figure 27, B. Above this bed, forming the roof, are a.few inches of shale

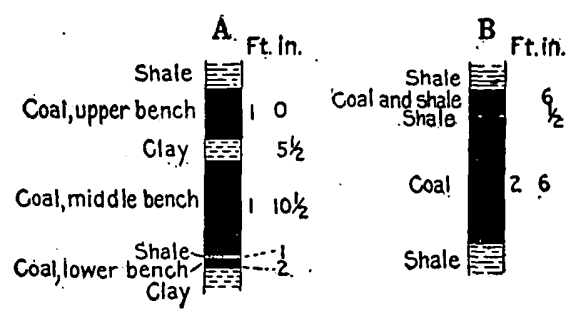

Figure 27.-Sections of Middle Kittanning (No. 6) coal bed in Gallia and Lawrence counties, Ohio. A, Greenfield Township; B, Perry Township.

and coal. An analysis of a sample from this place shows 10.9 per cent ash, 3.32 per cent sulphur, and a heating value of 11,930 B. t: u.

LOWER FREEPORT (NO. 6a) COAL BED.

The Lower Freeport (No. 6a) coal is of little value in Ohio and is worked in a fairly large way only at Steubenville. The coal as a rule lies 30 to 60 feet above the Middle Kittanning bed, whose prominence makes identification easy.

The Lower Freeport bed was once mined near Lisbon and was known locaily as the Whan coal. Its thickness was as much as 5 feet, but its area was small. Southeast, toward East Liverpool, the coal is thinner, being 2 feet or less, and in places is represented by shalé only. It has been mined in a small way along Yellow Creek, where it is known as the Roger coal, and has in places a thickness in excess of 3 feet. South of the mouth of Yellow Creek the Lower Freeport coal has been opened at many places in the hills facing the Ohio Valley, where its thickness is 30 inches or more. 
The Lower Freeport coal is mined in the vicinity of Steubenville under the name Steubenville Shaft coal. The first shaft was sunk in 1855 , and the coal was reached at a depth of about 187 feet. Since that time mining has been in progress, but coal is no longer shipped.

Section of Lower Freeport coal bed under Steubenville, Ohio.

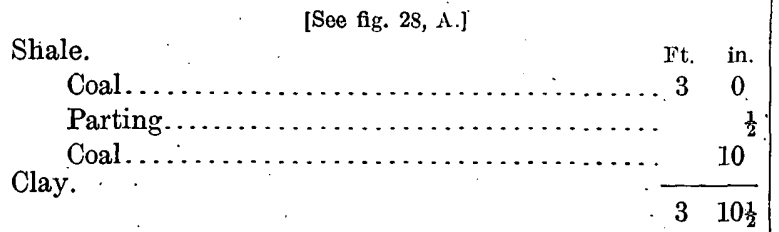

Although the bed in places attains a thickness of 5 feet, its usual measurement is about 4 feet. The coal is clean, has a bright luster, mines in small pieces, and cokes. It was formerly used rather extensively for coking, but it could not compete with the famous product from Connellsville, $\mathrm{Pa}$., and most of the ovens fell into decay; only a few are now in use. The coal has had a large use in rolling mills, and the La Belle Iron Works operates a mine for its own supply. It is a good steam fuel and has long had a market in Steubenville for domestic purposes.

The limits of the Steubenville field are not known, but the coal has been reached by shafts as far south as Rush Run, 10 miles below the courthouse. At Brilliant 5 feet of coal were found and at Rush Run 7 feet, but the upper and lower foot is of poor quality and for that reason was left in the mine. The coal bed is irregular in thickness, being in places absent and in other places too thin to work. No mining has been done from this shaft for many years. West of Steubenville the coal is under thick cover and no data at hand as to its thickness or quality. It probably extends north and northwest to Yellow Creek and in that event underlies a large area. The field is worthy of exploration and may prove valuable when better and more available supplies have been exhausted.

The Lower Freeport coal is the basis of an important mining industry in the vicinity of Amsterdam, Jefferson County; and north to Bergholz, being worked by four or five railroad shipping mines. In those at Amsterdam shafts are necessary, but about $3 \frac{1}{2}$ miles farther northeast the coal rises to the surface along the valley of Yellow Creek. It is undoubtedly the same as the Roger coal of the Ohio Valley.
Core-drill and well-record data show a large area of workable coal in the vicinity of Amsterdam and also eastward and southwestward for miles. There are, however, barren areas, and careful testing will be necessary to prove the extent of the coal.

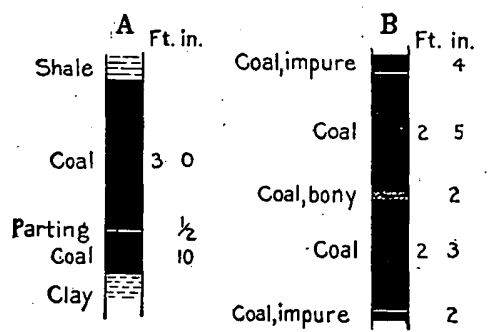

Figure 28.-Sections of Lower Freeport (No. 6a) coal bed in Jefferson County, Ohio. A, Steubenville; B; Amsterdàm.

The character of the bed in this vicinity is illustrated in figure $28, \mathrm{~B}$, and also by the following sections:

Section of Lower Freeport coal bed in Amsterdam mine, a mile south of Amsterdam, Ohio.

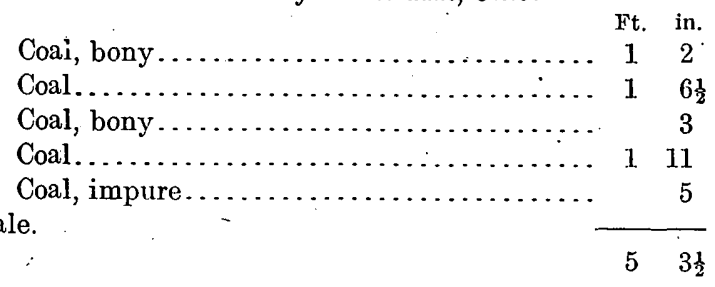

Section of Lower Freeport coal bed in Elizabeth mine, 2 miles east of Amsterdam, Ohio.

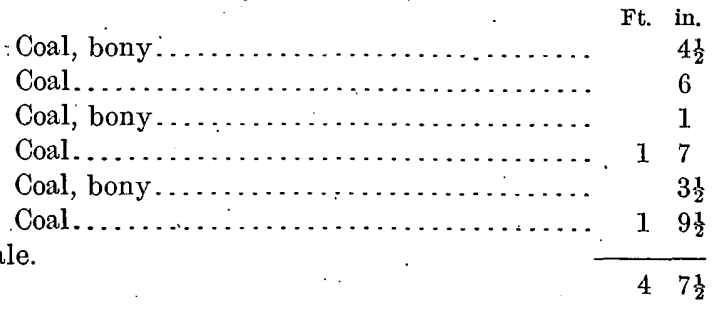

The average of the two samples from this mine gave, in proximate analysis, moisture, 3.4 , volatile matter, 38.0, fixed carbon 51.6, and ash 7.0 per cent, and in ultimate analysis carbon 73.31 , hydrogen 5.40 , oxygen 10.15 , nitrogen 1.46 , sulphur 2.71 , and ash 6.97 per cent. The heat value is $13,390 \mathrm{~B}$. t. $\mathrm{u}$.

The Lower Freeport coal can be followed southwest from Columbiana and Jefferson counties to the Hocking Valley, but it attains a thickness of 3 feet in few places and hence is of no value at present. In sec. 9, Clayton Township, Perry County, the bed is 3 feet 3 inches thick and has been mined locally by farmers: Much the same conditions prevail 


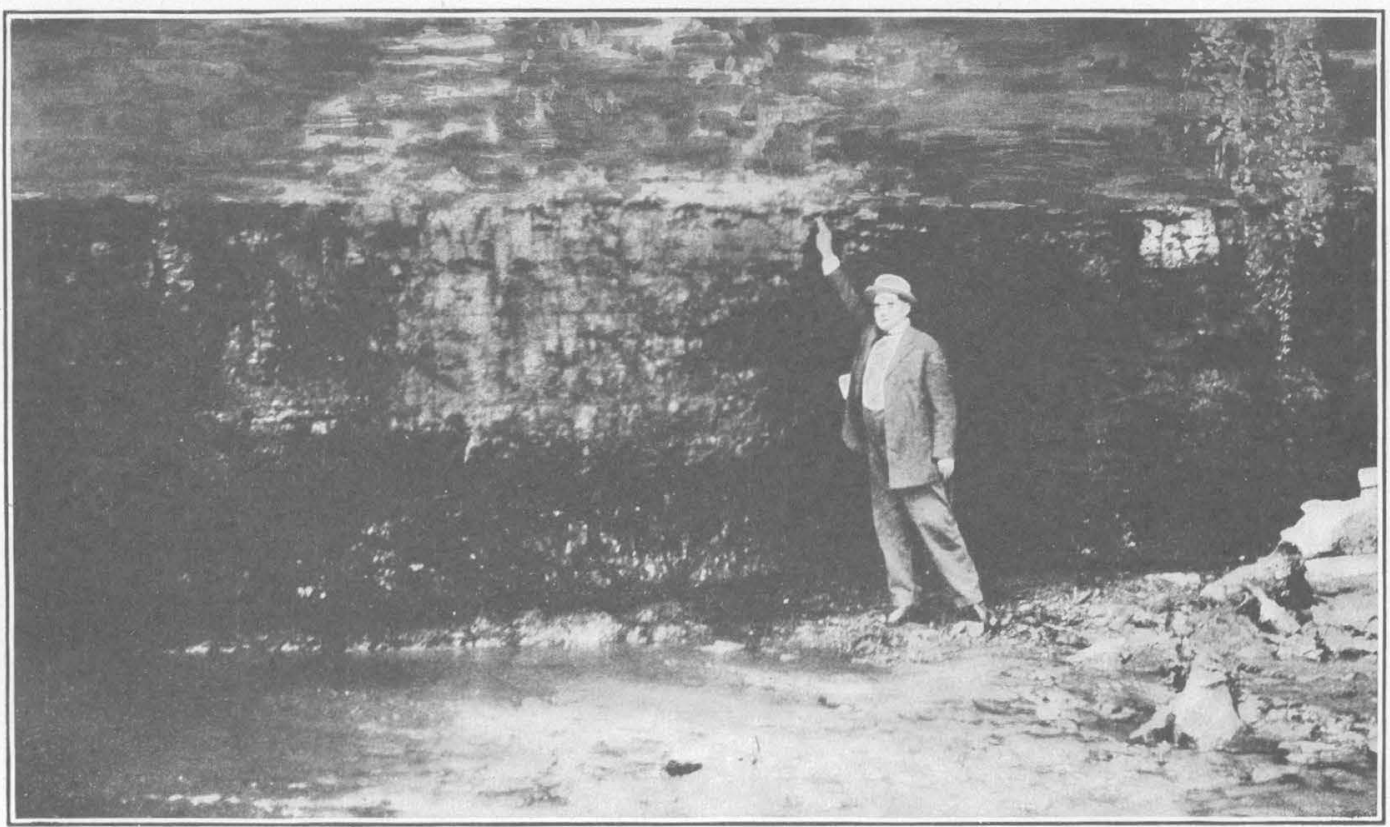

A. UPPER FREEPORT COAL BED IN CREEK BANK, SALINEVILLE, COLUMBIANA COUNTY, OHIO.

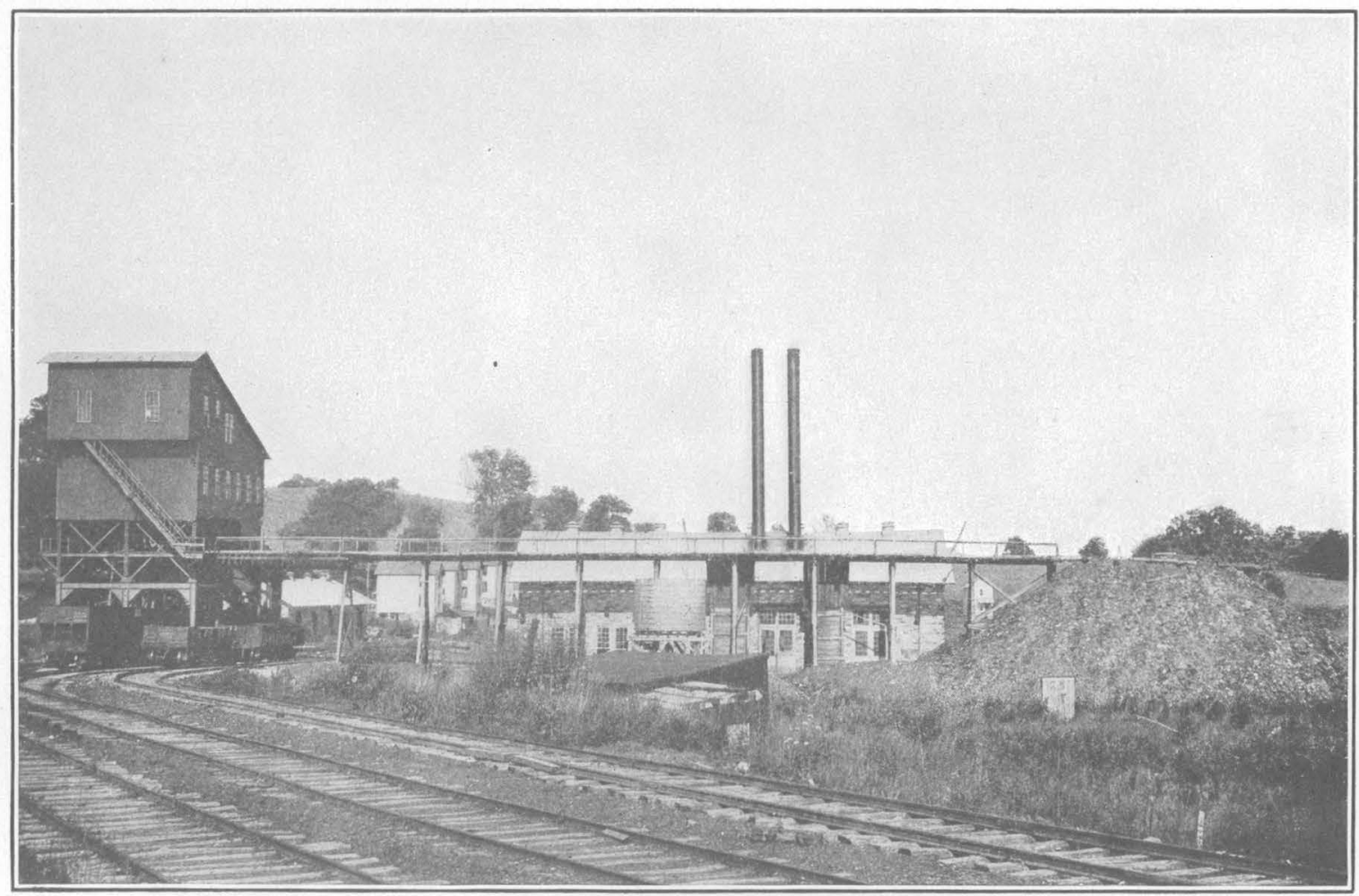

B. SHAFT MINE ON PITTSBURGH COAL BED AT LAFERTY, BELMONT COUNTY, OHIO. 
in Pike Township, but it is thicker in the vicin- ity of Moxahala, Pleasant Township, where it measures as much as 5 feet. However, the bed is irregular in thickness and the coal is high in sulphur. It has been mined at this place and was once used for making pig iron.

The coal attains workable thickness in Vinton County and has been mined in the vicinity of Hamden Furnace, where it measures 3 feet 8 inches. At present, however, it is not mined in either Vinton or Jackson counties except by stripping along streams. The thickness of the bed in these two counties rarely exceeds 20 inches. The coal is found in Lawrence County, where it is known as the Hatcher bed, but it rarely attains 2 feet 6 inches in thickness. At present it is mined in a very small way along Little Ice Creek in the southern part of the county.

UPPER FREEPORT (NO.7) COAL BED.

General features.-The Upper Freeport (No 7 ) is the third most important coal bed in Ohio, the more valuable ones being the Middle Kittanning (No. 6) and the Pittsburgh (No. 8). The relation of this bed to underlying ones is shown in the sections on page 42 . The Upper Freeport coal, like the Middle Kittanning, extends across the State from Columbiana County to Lawrence, but it lacks the persistence and regularity of the Middle Kittanning. In places it is well developed and worked on a large scale, but throughout more extensive areas it is thin and of little value. In places the Mahoning sandstone forms the roof, and in some of these it dips down and cuts out the coal in whole or in part. The coal is usually tender and herice does not bear transportation well. Moreover, it weathers rapidly. Nevertheless it is well adapted for steam purposes and has a large market.

Columbriana County.-In Columbiana County the Upper Freeport coal has long been mined at East Palestine, near the Pennsylvania line, where Orton measured the following section:

Section of Upper Freeport coal bed at East Palestine, Ohio [See fig. 29, A.]

Sandstone, Mahoning.

Shale, black

Coal ............................. 20

Parting.................................

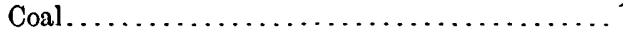

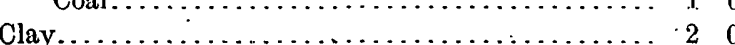

\begin{tabular}{ll}
2 & 0 \\
\hline
\end{tabular}
The coal bed measures 5 feet in thickness and is mined on a large scale at West Point, about halfway between East Palestine and Salineville. It has the same general structure as that at East Palestine and Salineville, but in places the bench below the parting is high in sulphur and therefore is not worked. At Salineville, another important center of development, the Upper Freeport coal, here known as the "Big vein," has been mined for railroad shipment for more than 50 years. (See Pl. IV, A.)

Section of coal in bank of Ỵellow Creek at Salineville, Ohio. Shale.

Coal............................. 8

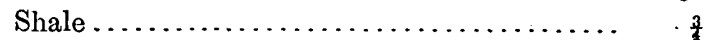

Coal................................. 30

Shale.............................. 1 Clay.

Coal............................. 110

$5 . \quad 5 \quad 73$

The upper parting in this section appears to be uncommon, for Orton says that the coal in

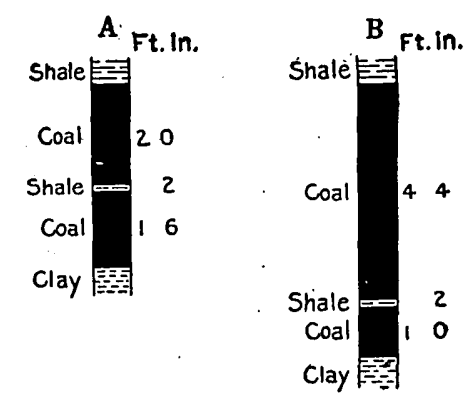

Fiaure 29.-Sections of Upper Freeport (No.7) coal bed in Columbiana County, Ohio. A, East Palestinc; B, Salinevilie.

the vicinity of Salineville has only one parting and that near the bottom. Orton's section is shown in figure 29, B. From this locality the outcrop of the Upper Freeport coal runs northeast and perhaps connects with that at West Point. About a mile west of Salineville the coal becomes so shaly that it can not be marketed, and it thins rapidly to the east and south.

Many years ago, when slack coal was simply waste, an unsuccessful effort was made to use the slack at this place for the manufacture of coke. Two grades were produced - a soft coke, which yielded 12.1 per cent of ash and 2.73 per cent of sulphur, for domestic purposes, and a harder variety, which gave 17.5 per cent of ash and 3.66 per cent of sulphur.

Carroll County.-Toward the southwest lies the Dellroy or Sherrodsville field in the southwest corner of Carroll County. This field 
extends into Monroe Township on the north, nearly to Bowerston on the south, nearly as far as Carrollton on the east, and into Tuscarawas County on the west. A number of mines for railroad shipment have been worked, but all have been abandoned, and the best of the bed is reported to have been worked out. Sherrodsville is said to have had, when mining was at its height, a population of 1,450 , but now it has only 350. The coal at its best was 6 feet thick, but it was inconstant, and miners could not count on any definite thickness. The following section by Orton is as representative as a single section can be of an irregular coal bed.

Section of Upper Freeport coal bed at Sherrodsville, Ohio.

Shale, black.

Coal......

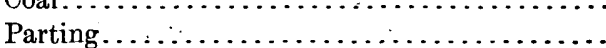

Clay:

Coal......................

The coal is still mined at a number of places for the use of farmers, and the supply is adequate for that purpose for generations.

Tuscarawas County. - The Upper Freeport coal is of some importance in Tuscarawas County. It is now mined for railroad shipment near Midvale and Stillwater, but its area near the latter place is reported to be small.

Guernsey County.-Guernsey County, which lies south of Tuscarawas, forms part of one of the largest coal fields of Ohio. Plate $V$ shows four areas in this county in which the Upper Freeport coal bed is of minable thickness. In the northern part of the county the Upper Freeport coal does not appear to have great value, but it is mined in places by farmers. The principal area of workable coal lies south of Cambridge, as shown on Plate V. In this field the coal bed thickens greatly in a short distance south of Cambridge, and it extends southward to the vicinity of Caldwell, Noble County. Cambridge has always been considered headquarters for this field, and the fuel is known in the market as the Cambridge coal. The western boundary of the field, considering it to be limited to territory in which the coal is 4 -feet or more thick, is in the longitude of Cambridge and its eastern boundary in that of Lore City. 'See Pl. V.) However, to the east the coal is below drainage, and its limits can be determined only by the drill. The field is drained by Wills and Leatherwood creeks and most of the mines are on those streams. The coal dips below Leatherwood Creek near the eastern boundary of Cambridge Township and below Wills Creek about one-half mile north of Byesville:

The structure of the bed, as shown by figure 30 , is similar to that already reported from Columbiana and Carroll counties. It consists of two benches, with a parting near the bottom. The maximum thickness is 7 feet, but the Mahoning sandstone in places cuts out the

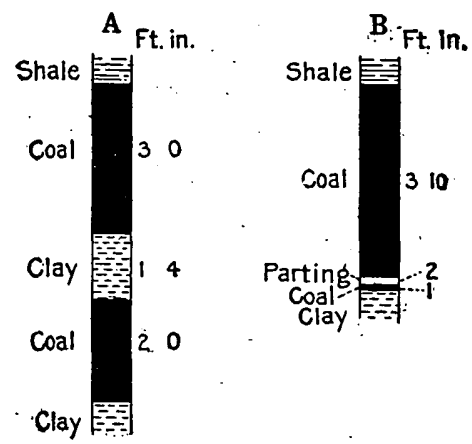

Figure 30.-Sections of Upper Freeport (No. 7) coal bed in Guernsey County, Ohio. A, Cambridge Township; B, Center Township.

coal in whole or in part, greatly handicapping the field.

Section of Upper Freeport or Cambridge coal bed in old Nicholson r.ine near Cambridge,Ohio.

"Draw slate"

Coal with numerous shale partings, none per-

sistent.......................... $4 \quad 6$

Clay..................................... 2

Coal.............................. 4

Clay.

An analysis of this coal from the Forsythe mine, Danford, Guernsey County, ${ }^{1}$ gives volatile matter 38.2, fixed carbon 54.0, ash 7.8, and sulphur 3.79 per cent. The heat value is 13,550 B. t. u.

Although the bed has only one regular parting, it has many thin discontinuous ones in places, and these increase the percentage of ash and sulphur. The coal is tender and does not bear transportation well. Its largest use is in steam production, but it has also a fair market for household use. Under normal industrial conditions about 25 mines 1 As this analysis is of theoretically dry coal, it should not be com. pared with other analyses given in this paper. 


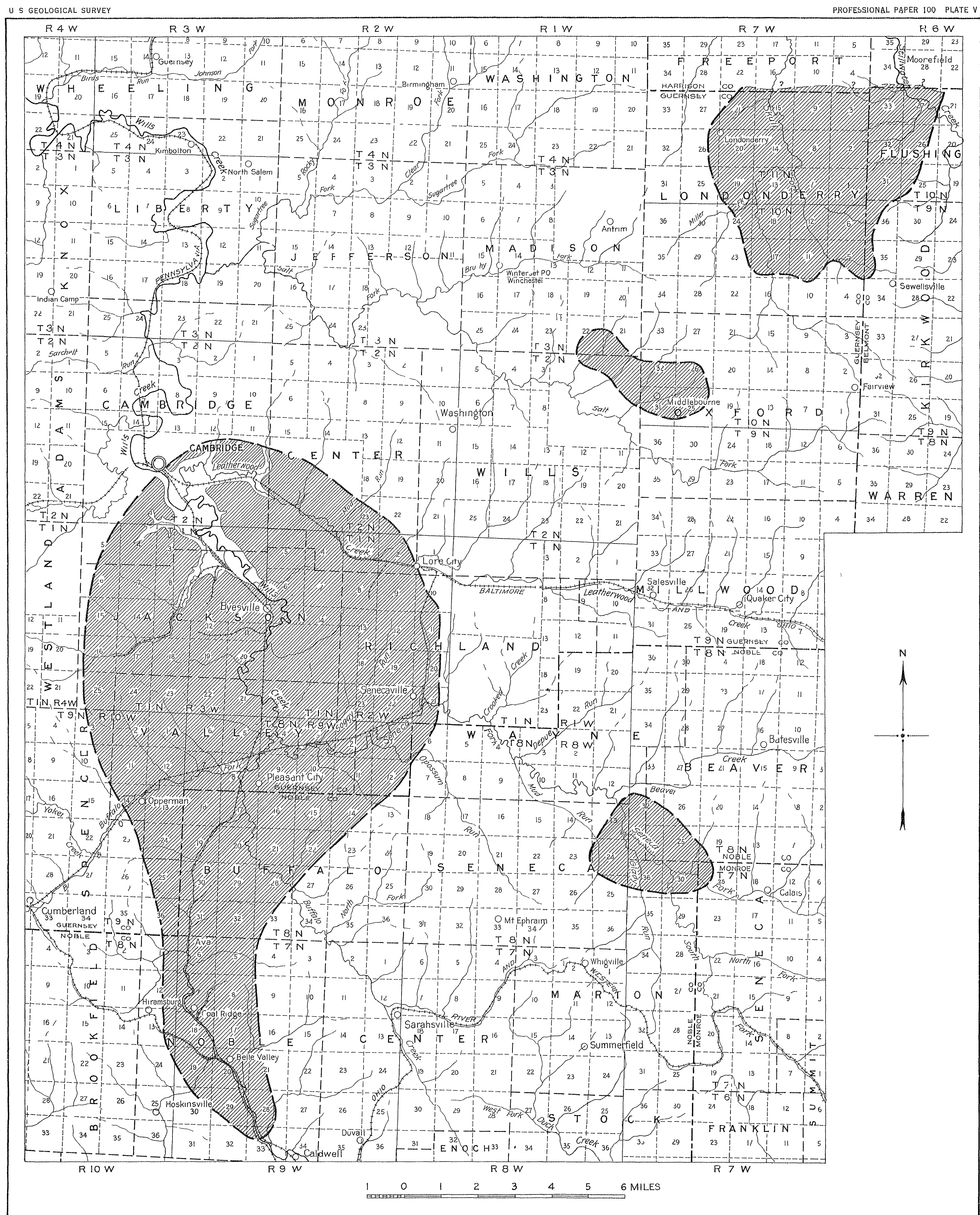

MAP OF THE CAMBRIDGE COAL FIELD (UPPER FREEPOR $\Gamma$ OR NO 7 COAL BED), EASTERN OHIO

Heavy broken lines limit areas of minable coal 
are in operation. The field has been worked in a large way for 40 years and has apparently reached, if not passed, its zenith. Extensions during the past few years have been largely to the south, in which direction much prospecting with the drill has been done.

The following figures indicate the production of the Cambridge field in short tons, nearly all of which came from-the Upper Freeport bed.

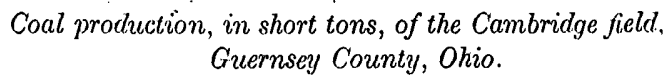
Guernsey County, Ohio.

Muskingum County.-The Upper Freeport conl is found in every township east of the river in Muskingum County, but under much of this large area the bed is thin and of little value. It has been worked by farmers at several places, notably in the vicinity of Sonora and Zanesville, where it attains a maximum thickness of 5 feet 6 inches. A section of the bed in Wayne Township, a few miles south of Zanesville, in represented in figure $31, \mathrm{~A}$. It is now mined for railroad shipment on the narrow-gage railroad 5 miles east of Zanesville. Near Blue Rock, on the river in the southern part of the county, the coal was long mined for local trade. The bed is normally 4 feet thirk in this field, and the conl is very bright and high in volatile matter.

However, the most valuable area of the Upper Freeport coal in Muskingum County lies in the southwestern part and includes. a large part of Brush Creek Township, about one-third of Clay Township, and nearly three sections in Newton Township. It has long been mined by farmers. It has a generally constant thickness of about 4 feet, containing few shale or clay partings.

Section of Upper Freeport coal bed in Maynard Bros. mine, Brush Creek Township, Muskingum County, Ohio.

shale.

Coal, upper bench

Pyrite and shale.............................

Coal, lower bench.................... 27 Clay.

27

A proximate analysis of a sample from this mine gives moisture 4.7 , volatile matter 43.5 , fixed carbon 44.2 , and ash 7.6 per cent; and an ultimate analysis gives carbon 68.27 , hydrogen 5.55, oxygen 12.30 , nitrogen 1.32 , sulphur 5 , and ash 7.56 per cent. The heat value is $12,680 \mathrm{~B}$. t. u.

Perry County.-From Muskingum County the Upper Freeport coal can be followed southwest into Perry County; where it has long been worked by farmers and is now mined for railroad shipment at Burr Oak, in the southern part of Monroe Township. The coal is at its best, so far as thickness is concerned, in this township, where it has a maximum of 6 feet, with the usual character of the bed and quality of the coal. It is locally known in parts of Perry County as the Norris coal.

Athens County.-South of Monroe Township it is thick in Trimble and Dover townships, Athens County, and has long been mined

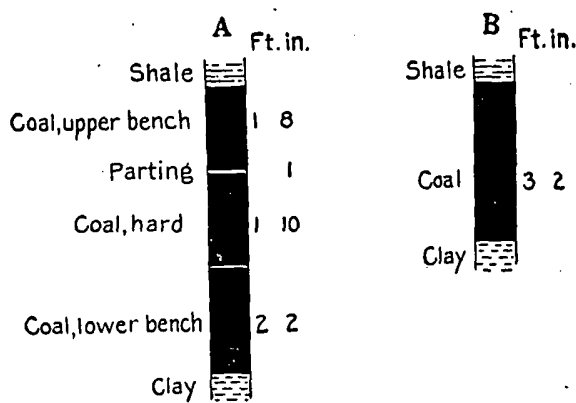

Figure 31.-Se.tions of Upper Freeport (No. 7) coal bed in Ohio $\Lambda$, Wayne Township, Muskingum County; B, Symmes Township, Lawrence County.

for railroad shipment along the Sunday Creek valley. It is now worked in the large way at Palos, Jacksonville, between Jacksonville and Millfield, and near Millfield.

Section of Upper Freeport coal bed at Jacksonville, in southern Trimble Township, Athens County, Ohio. Shale.

Coal, upper bench................... 2 2

Shale.............................. 2

Coal, lower bench...................... $2 \quad 2$ Clay.

$4 \quad 6$

The coal was formerly coked on a small scale néar the western border of Dover Township. Only the slack seems to have been used, and it was dirty and high in sulphur. The coke could not be used in high-grade foundry work.

York Township, which lies west of Dover, contains an important area of the Upper Freeport coal, which is mined for railroad shipment 
at Buchtel, Doanville, and near Nelsonville. At its best the bed is 6 feet thick but is somewhat dirty; owing to thin shale or clay partings. An analysis shows 8.3 per cent ash. The coal has been mined in a small way in Waterloo and Athens townships in the same county; its area is large, but the coal in Athens Township is reported to be irregular in thickness.

Vinton County.-The Upper Freeport coal is of very little value in Vinton County, the only known workable areas being in Wilkesville Township, where in a very small area in sec. 22 it has a maximum thickness of 6 feet.

Jackson and Lawrence counties.-The Upper Freeport coal is found in the hills along the eastern border of Jackson County, but it is thin and nowhere mined. The bed has long been worked for local use near Rockcamp in the southern part

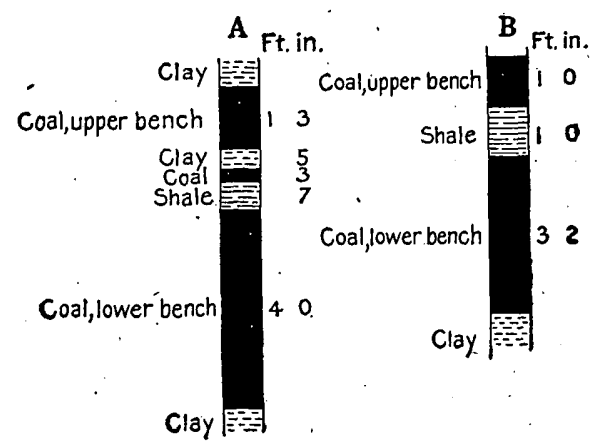

Figure 32.-Sections of Upper Freeport (No. 7) coal bed in Lawrence County, Ohio. A, Symmes Township; B, Aid Township.

of Lawrence County, where it has a maximum thickness of 3 feet. It attains importance in Symmes Valley in the eastern part of the county, where it is known as the Waterloo bed. Its thickness there is very irregular and may reach 6 feet, but in places the coal is wanting. The two benches found elsewhere are generally present in this field, but the parting is in many placos expanded and may measure a foot or even more. The character of the coal bed in this valley is shown in figure $31, \mathrm{~B}$, and in figure $32, \mathrm{~A}$ and $\mathrm{B}$.

COAL BEDS IN THE CONEMAUGH FORMATION.

The Conemaugh formation, formerly known as the "Lower Barren Coal Measures," lies between the Upper Freeport (No. 7) and the Pittsburgh (No. 8) coal beds. The formation outcrops in a broad band 5 to 28 miles in width stretching from Columbiana County southwestward to Lawrence County at the extreme southern point of the State. It ranges in thickness from 355 feet in soutbern Ohio to 500 feet in the eastern part of the State.

Generalized section of the Conemaugh formation in Noble and adjoining counties.

[By D. D. Condit.]

Coal, Pittsburgh, basal member of the Monongahela formation. - Feet.

Limestone and clay....................... 5

Sandstone or sandy shale .................... 21.

Limestone in several layers, generally with a lumpy brecciated or pebbly surface; buff color common...

Shale, with alternating beds of sandstone and cläy, commonly reddish brown................... 120

Shale, sandy, or locally sandstone (Morgantown mem-

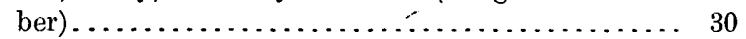

Limestone, Ames or "Crinoidal" member......... 2

Shale................................. 11

Coal, Harlem, usually thin, workable at Harlem Springs, Carroll County.

Shale or red clay, locally replaced by sandstone (Saltsburg member)...................... 20

Limestone, nodular or in continuous layers........ 3

Shale, sandy, with local lentils of massive sandstone

(First Cow Run sand of oil drillers) ........... 60

Coal, Anderson (Bakerstown of Pennsylvania and West.Virginia); 18 inches to 2 feet thick near Lore City and PJeasant City, Guernsey. County, and locally of similar thicknesses to the south and southwest in Noble and Morgan counties. The roof shale is black and contains marine fossils.

Clay, with nodular limestone. . . . . . . . . . . .

Limestone, Cambridge member, dark gray, fossiliferous; varying from nodular to a single continuous layer; well suited for use as road material.......... Shale, locally replaced by a bed of massive sandstone (Buffalo member), especially prominent along Stillwater Creek, in Tuscarawas County............. 38 Shale, dark, with marine fossils and one or more thin coal beds (Brush Creek member). . . . . . . . . . . 20

Sandstone, shaly to massive................. 20

Clay and shale, with one or more limèstone layers. ... 10

Sandstone, shaly........................ 45

Shale and clay, with locally a thin coal (Mahoning member $\ldots \ldots \ldots \ldots \ldots \ldots \ldots \ldots \ldots \ldots \ldots \ldots . .10$

Sandstone, shaly to massive (Mahoning member)... 35 Upper Freeport or Cambridge coal, top member of Allegheny formation.

In southern Ohio, according to Condit, the general section is similar to that just given, though the formation is thinner and presents minor variations. 


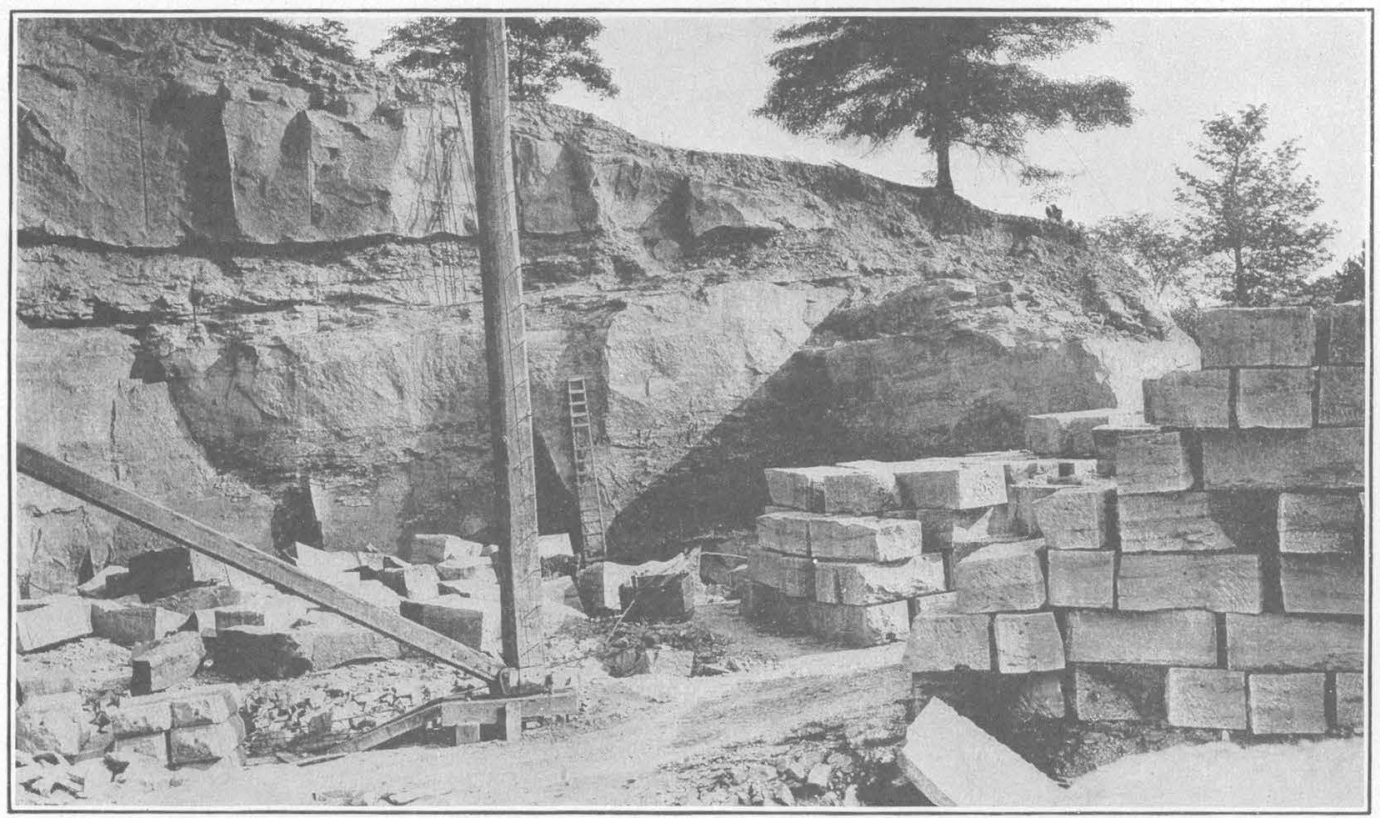

A. QUARRY IN MAHONING SANDSTONE MEMBER NEAR CORNING, PERRY COUNTY, OHIO.

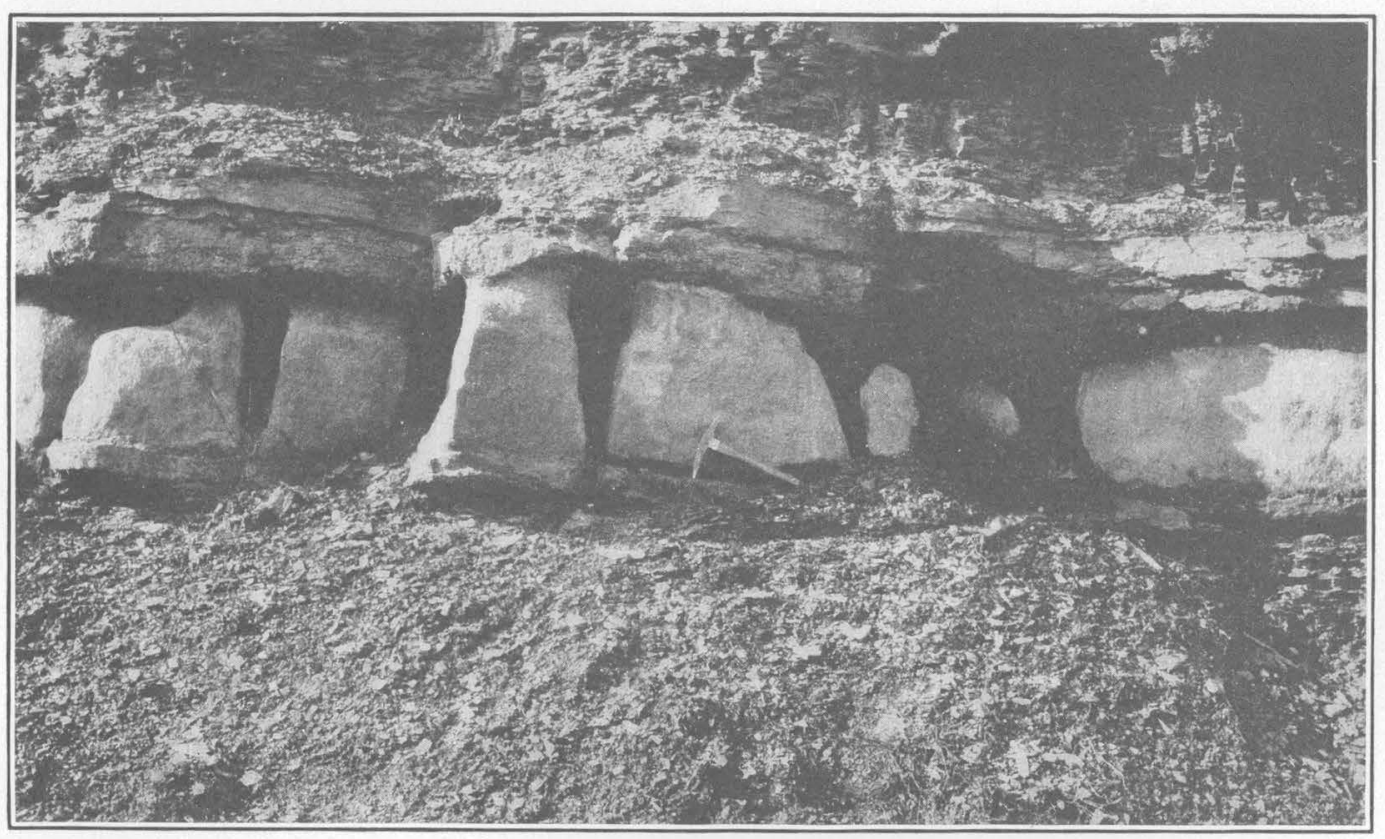

B. BRUSH CREEK LIMESTONE MEMBER OF THE CONEMAUGH FORMATION NEAR DEXTER, MEIGS COUNTY, OHIO. 
General, section of the Conemaugh formation in Meigs County, Ohio.

Limestone, nodular or in layers, interlain with $\mathrm{Ft}$. in.

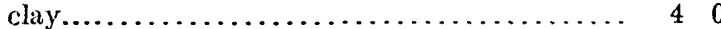

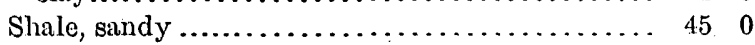

Sandstone (Connellsville member), massive to

shaly.............................. $30 \quad 0$

Coal, "blossom."

Limestone, nodular........................

Shale, sandy, with red beds.....................

Clay, red, with concretions of hematite............

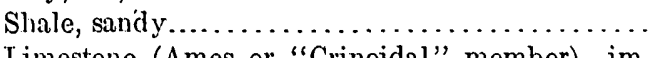

Limestone ( $A$ mes or "Crinoidal" member), im-

pure and sandy in many localities.............

Shale, sandy $\ldots \ldots \ldots \ldots \ldots \ldots \ldots \ldots \ldots \ldots \ldots \ldots \ldots \ldots$
Clay shale, red, with nodular limestone ("Round

Knob horizon"; "Pittsburgh reds")........... Coal, Anderson (Bakerstown), thin.

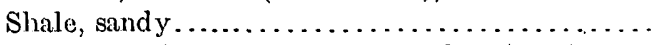

limestone (Cambridge member), dense, dark gray, fossiliferous; missing in many localities........

Shale; sandy............................

Limestone (Brush Creek member), shale, and sandstone, all fossiliferous.................. $30 \quad 0$

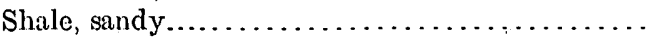
Coal, Mason.

Sand stone, shaly to massive................... Coal, Mahoning, thin.

Clay, with ferruginous limestone at top............

Sandstone (Mahoning member), massive..........

Coal, Upper Treeport (No. 7); top member of the Allegheny formation.

35.12

The rocks of the Conemaugh formation have been described by Condit to consist

mostly of sandstone, sandy shale, and clay, much of which has a reddish-brown color. Coal beds and limestones are few and thin. All of the beds are characterized by lack of persistence, and vary greatly from place to place as to thickness and appearance. Local erosion planes and unconformities of small magnitude are abundant and occur at all horizons. These hiatuses are shown by conglomeratesand truncated strata. Frequently the material of the conglomerates can be traced to some near-by fossiliferous limestone or coal bed. [See Pl. VI, $A$.]

The lower half of the Conemaugh formation is largely of marine origin and includes a number of fossiliferous beds, the highest of which, lying a little above the middle, marks the final invasion of the sea into the Appalachian Basin. All overlying strata lack forms of undoubted marine origin, their fossils being mostly plant remains and certain minute fossils, such as Spirorbis, ostracods, and gastropods, generally regarded as fresh-water, with some fish, amphibian, and reptilian bones. Some insect remains are well preserved in the shale. The marine limestones of the lower half of the for- mation are the most persistent and lithologically uniform (see Pl. VI, $B$ ); but even these have suffered contemporaneous erosion and are locally missing, owing to unfavorable conditions of deposition, such as the presence of shoals in the sea and continuous sedimentation from rivers. ${ }^{1}$

The coal beds of the Conemaugh formation are thin and unimportant, though they are worked at places by farmers and at one place for railroad shipment. The Mahoning bed is the lowest of these coals and is rated by Condit as the most important. It is known by several local names, such as Groff in the upper Ohio: Valley, Strip at Salineville, and Finley along Island Creek in northern Jefferson County. Its most valuable areas are in $\mathrm{Co}-$ lumbiana, Jefferson, and Carroll counties, throughout large parts of which the bed ranges from 2 to 3 feet in thickness. Condit states that this. coal is at its best in the vicinity of Salineville, where it measures as much as 38 inches, has a shale parting about 10 inches above the base, and lies only 32 feet above the Upper Freeport or "Big vein." About 2 miles west of Salineville, in the eastern part of Carroll County, this coal is worked for railroad shipment by two companies, and it is the only place in Ohio where a coal in the Conemaugh formation is mined for such shipment. Along Island Creek in northern. Jefferson County the Mahoning coal bed is from 3 feet to 4 feet 6 inches in thickness and has long been mined for local use. From what has been said it is apparent that the Mahoning coal is at least of marked local value.

The Mason coal, although persistent; is of little value except in eastern Ohio, where it lies about 75 feet above the Upper Freeport coal. Condit states that it is mined at several places along the Youngstown \& Ohio River Railroad in Madison Township, Columbiana County, and is from 3 feet to 3 feet 6 inches thick, but these dimensions do not appear to persist throughout wide areas.

The Wilgus coal bed is 18 to 36 inches thick in parts of Gallia and Lawrence counties in the southern part of the State and is worked for a local supply on many farms, especially in the valley of Symmes Creek. The Cambridge limestone forms its roof.

1 Condit, J. D., Ohio Genl. Survey, 4th ser., Bull. 17, p. 15, 1912. 
The Anderson coal, according to Condit, is workable orer much of Muskingum and Morgan counties and in places in Guernsey, Noble, and Harrison counties. In Muskingum County it is reported at its best in Union, Salt Creek, and Blue Rock' townships, where its thickness is 2 to 3 feet. and its quality is very good. In southwest Harrison County it is 1 foot 6 inches to 3 feet thick, though the 3 -foot thickness is not common. It is mined on a few farms. On the property of the Noble Brick Co. at Glenwood station, Noble County, the Anderson coal is 23 inches thick, and it has been opened on many farms along Buffalo Creek in the northern part of this county.

The Barton coal bed, lying about halfway between the Ames and Cambridge limestones, is thin and of small value even locally. In southern Carroll County it is 20 to 24 inches thick and is worked in a few mines. The shale roof is strong and requires little or no timbering. The coal is of good quality.

The Harlem coal, the highest bed of workable thickness in the Conemaugh formation, is at its best in Jefferson, Carroll, and Harrison counties. Harlem Springs, in the southeast part of Carroll County, is its best-known locality and supplies coal to the farmers for miles in all directions. Although the coal does not attain a thickness of 3 feet, it reaches 2 feet 6 inches throughout a broad area.

\section{COAL BEDS IN THE MONONGAHELA FORMATION.} GENERAL FEATURES.

The Monongahela formation, formerly known as the "Upper Productive Coal Measures," outcrops as a broad belt from Jefferson County soutbwest to Lawrence County and includes parts of Jefferson, Harrison, Belmont, Guernsey, Monroe, Noble, Morgan, Muskingum, Washington, Athens, Meigs, Gallia, and Lawrence counties. The formation has for its basal nember the Pittsburgh (No. 8) coal and for its summit the Waynesburg bed. Orton credited the formation with a thickness of 200 feet; and Condit's section differs but little from this. The formation contains three important coal beds, the Pittsburgh, Pomeroy, and Meigs Creek, and two beds of lesser value, the Uniontown arid Waynesburg. The relative positions of these are shown in the following section.
Generalized section of the Monongahela formation in Belmont and adjoining counties, Ohio.

[By D. D. Condit.]

Coal, Waynesburg, mined at Somerton, Newcastle, and Hunter, Belmont County; high in ash; usually. a solid bed with no persistent clay or bone bands.

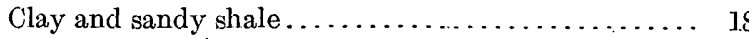

Coal, thin.

Clay and buff limestone . .................. .4

Sandstone, varying from shaly and cross-bedded to massive; quarried west of Miltonsburg, Monroe

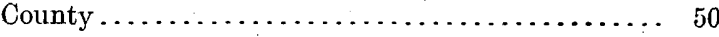

Coal, Uniontown; mined near Funter, Belmont County, and along Sunfish Creek, east of Woodsfield, Monroe County; high in ash and usually has several clay bands.

Clay, with thin layers of nodular limestone ....... 10

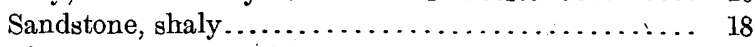

Limestone (Benwood member), numerous beds 1 to 2 feet thick, interlayered withc alcareous clay. In the lower portion is a conspicuous bed of olive-green clay.

Coal, Meigs Creek; workable in Belmont County and also over much of Noble, Washington, and other counties to the southwest; rather high in ash but seldom has persistent bands of clay or bony coal.

Sandstone, varying from shaly to massive and coarse

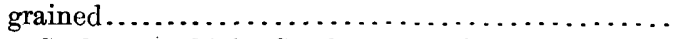

Coal, Lower Meigs Creek; workable in a few localities near Temperanceville, Belmont County, and southward in Monroe County; contains many bands of impurities and much "sulphur."

Limestone.............................. 4

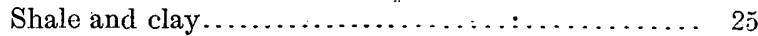

Limestone, yellowish $\ldots \ldots \ldots \ldots \ldots \ldots \ldots \ldots \ldots \ldots, 3$

Sandstone, shaly........................... 30

Coal, Pomeroy; thin or wanting................

Limestone, laminated, black, underlain by yellowish

limestone layers............................. 4

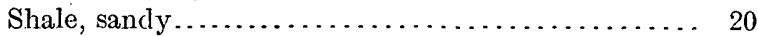

Coal, Pittsburgh; present in workable thickness throughout nearly the whole of Belmont County and parts of the surrounding counties.

PITTSBURGH (NO. 8) COAL BED

genERAL FEATURES.

The Pittsburgh or No. 8 coal is one of the two most important coal beds in Ohio, its only rival. being the Middle Kittanning (No.6) bed, which is more persistent, has a larger acreage, and is of a little better quality. The Pittsburgh coal in Ohio occupies three widely separated fieldsthe Belmont County field; the Federal Creek field of Morgan and Athens counties, and the Swan Creek field of Gallia County. Outside of these fields the coal is thin and usually worthless. 
BELMONT FIELD.

General features. - The Belmont field is by far the largest of the three fields mentioned. It includes nearly the whole of Belmont County, the southern two-fifths of Jefferson County with numerous outliers farther north, the southeastern third of Harrison County, several ridges in the southeastern corner of Guernsey County, the northeastern corner of Noble County, and a somewhat undetermined area in the northern part of Monroe County. (See Pl. VII.)

Ohio River cuts through the coal as far as the southeast corner of Belmont County, where it is said to flow on top of the bed. Several western tributaries, the largest of which are Short Creek, Wheeling Creek, and McMahon Creek, also cut through the coal bed, making it accessible and providing easy routes for railroads. However, throughout a large area in central Belmont County the coal is below drainage and can be reached only by shafting. In Monroe County the coal is everywhere under cover except in the northwest corner, where it has been trenched by the headwaters of Wills Creek.

Throughout this large area the principal structural features of the bed are uniform except along the western border. In the townships fronting on Ohio River the structure is similar to that in the type locality, southwestern Pennsylvania, and is as follows:

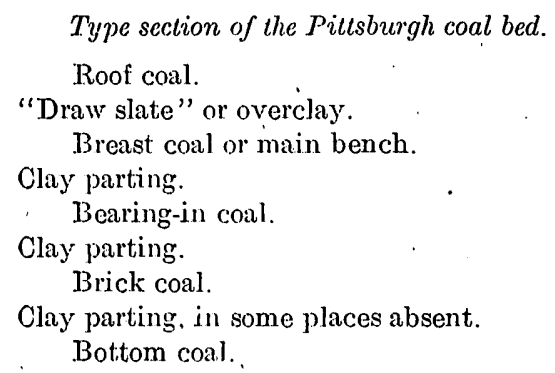

Along the western border of the field the breast coal thins and in places the bearing-in coal is lacking. In a mine at Temperanceville, Belmont County, the coal bed consists of two benches separated by a shale parting and has a structure similar to that in the Federal Creek and Swan Creek fields. The "draw slate" or " overclay commonly ranges in thickness from a few to 18 inches. Above it is the roof coal, which rarely attains a thickness of 2 feet and $73210-17-3$ is not mined. In many places it is associated with shale and forms the mine roof.

Belmont County.-No other county in Ohio is so favored with coal as Belmont. The hilltops in the southern half of the county rise to or above the horizon of the Waynesburg coal, which is a local source of fuel on some of the farms. The next lower coal bed is the Uniontown, which is worked at a score or more places in the county and may become a source of fuel of real value when the much more important beds lying below it have been worked out. The Meigs Creek coal, 3 to 4 feet thick, is 100 to 140 feet below the Uniontown and underlies the entire county except along the west border, in the northeast corner, and in narrow strips along a few streams. More important than all these beds combined, however, is the great Pittsburgh coal bed, 3 to 5 feet thick, which underlies the entire county except the northwest corner, where the headwaters of Stillwater Creek have swept the coal away; the valleys of Wheeling and McMahon creeks; a narrow strip along Ohio River; and a few hundred acres in the southwest corner of the county. Throughout this large area the thickness of the bed and quality of the coal, though subject to some variation, are remarkably uniform. The coal is at its best along the Ohio Valley, where it is thicker, a little lower in ash and moisture, and greater in heat value than elsewhere. Along the river front in the northern part. of the county the coal is high in the hills, but its dip carries it to the level of the flood plain in the vicinity of Bellaire and to the bed of the river in the southern part of the county.

As it outcrops so prominently the coal must have been known from the time of settlement and was probably mined for household purposes as early as 1825. Shipment by river was started about 1835 and had become an important industry by 1845 , the coal going as far as New Orleans. The Baltimore \& Ohio Railroad began hauling coal about 1858 from a mine a mile west of Bellaire and from that time to 1900 the output of the field grew steadily; since 1900 the increase has been very rapid. Belmont County is now by far the largest producer in the State; in 1913, before the disastrous strike, it produced more coal than 
any other two counties in Ohio. The following figures indicate the growth of the industry:

Production of coal in Belmont County, Ohio, in short tons.

\begin{tabular}{|c|c|}
\hline & 774,110 \\
\hline 1895 & 846,643 \\
\hline 1900 & $1,345,284$ \\
\hline 1905 & $3,957,980$ \\
\hline 1910. & $8,265,019$ \\
\hline 1913 & $10,436,2$ \\
\hline 1914 & $2,849,1$ \\
\hline 1915. & $4,304,56$ \\
\hline
\end{tabular}

The shipping mines, of which there are about 50 , are distributed along the river front or the
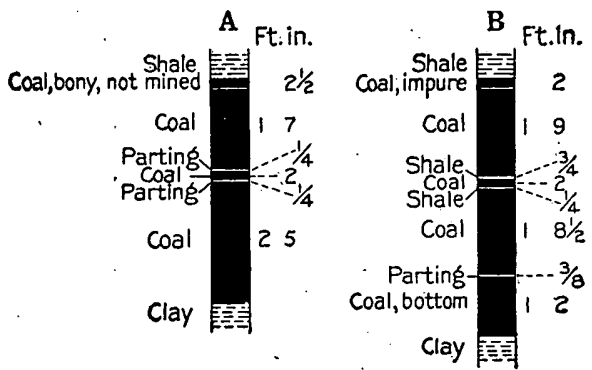

Figure 33.-Sections of Pittsburgh (No. 8) coal bed in Belmont County, Ohio. A, Flushing Township; B, Union Township.

Baltimore \& Ohio and its branches. As yet the southern two-fifths of this county has hardly been touched and constitutes a fuel body of great value. The coal bed is nearly uniform, but a few sections of it will be given. Figure 33, $\mathrm{A}$ and $\mathrm{B}$, shows the coal bed in the northwest corner of the county and figure 34 , $\mathrm{A}$ and $\mathrm{B}$, in the northeast corner.

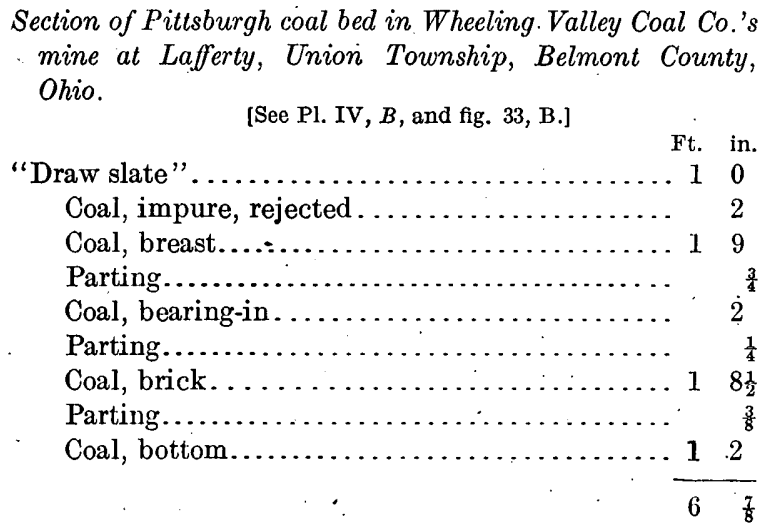

A proximate analysis of a sample from this mine shows moisture 4.5, volatile matter 36 , fixed carbon 48.8, and ash 10.7 per cent; an ultimate analysis shows carbon 68.24 , hydrogen 4.85 , oxygen 10.60 , nitrogen 1.10 , sulphur 4.45 , and ash 10.76 per cent. The heat value is 12,430 B. t. u. The surface plant at this mine is shown in Plate IV, $B$ (p. 56).
The character of the bed in the vicinity of Bellaire is shown by the following section:

Section of Pittsburgh coal bed in Empire Coal Mining Co.'s mine, 1 mile south of Belleire, Ohio.

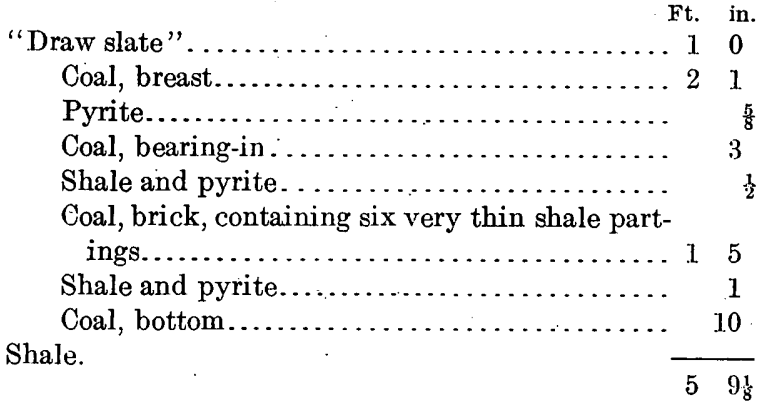

The proximate analysis of a sample from this mine shows moisture 3.5 , volatile matter 38.6 , fixed carbon 51 , and ash $6 . \dot{9}$ per cent; an ultimate analysis shows carbon 72.06, hydrogen 5.45 , oxygen 10.70 , nitrogen 1.17 , sulphur 3.76 , and ash 6.86 per cent. The heat value is 13,190 B. t. u.

This section and analyses may be considered typical of the coal in the dozen or more mines in the vicinity of Bellaire. The coal is well shown along McMahon Creek to a point near Glencoe, where it passes below drainage.
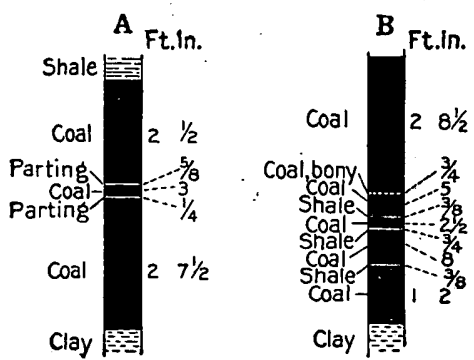

Figure 34.-Sections of Pittsburgh (No. 8) coal bed in Belmont County, Ohio. A, Pease Township; B, Colerain Township.

The character of the Pittsburgh coal bed in Mead Township is shown in figure 35, A, and by the following section, which includes the roof coal:

Seotion of Pittsburgh coal bed in Johnson Bros.' mine near mouth of Pipe Creek, Belmont County, Ohio.

Ft. in.

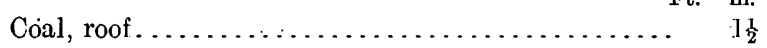

"Draw slate".......................... 14

Coal, breast.............................. 2

Shale....................................

Coal, bearing-in................... $4 \frac{1}{2}$

Shale............................

Coal, brick and bottom................. $\frac{3}{3} 2$ 


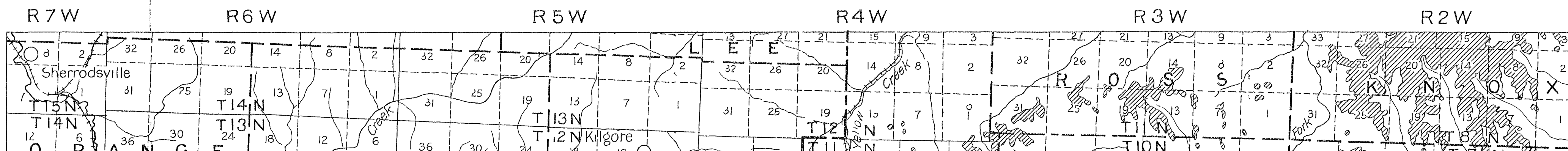

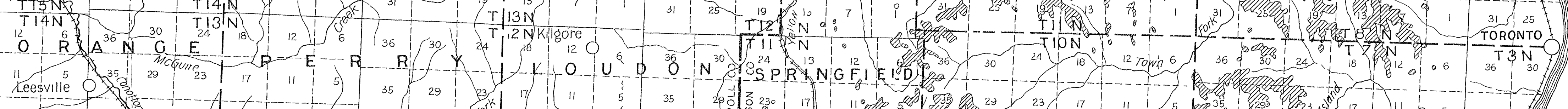

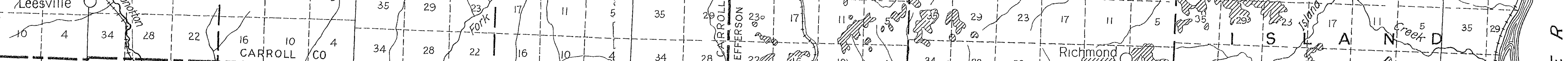

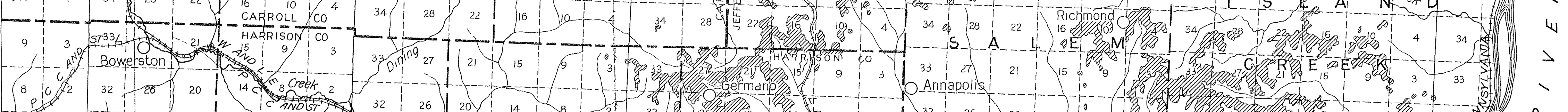

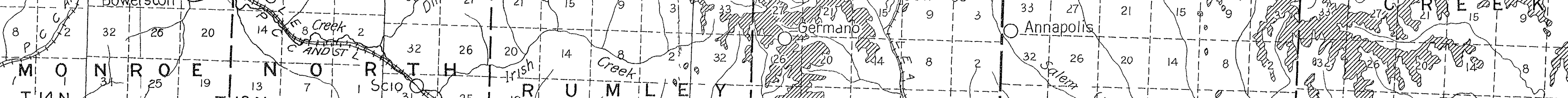

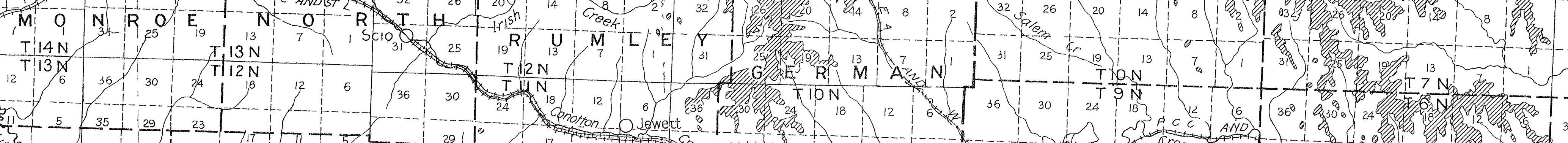

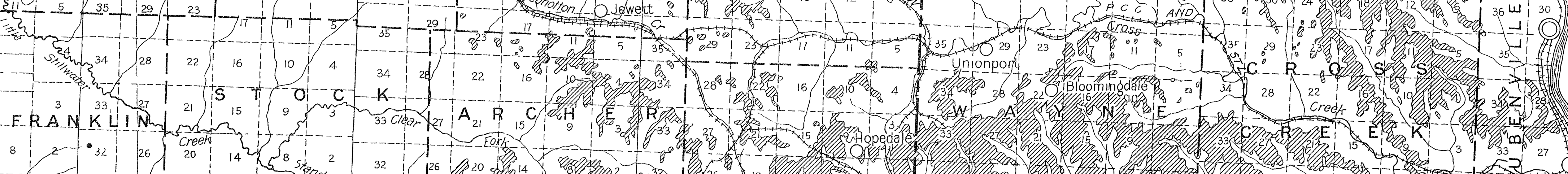

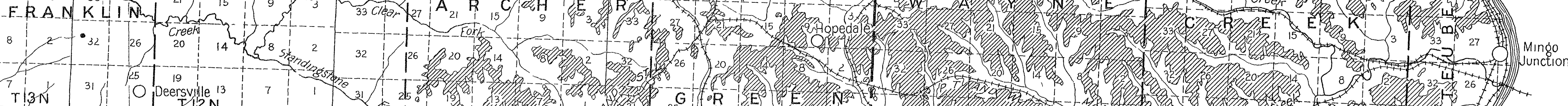

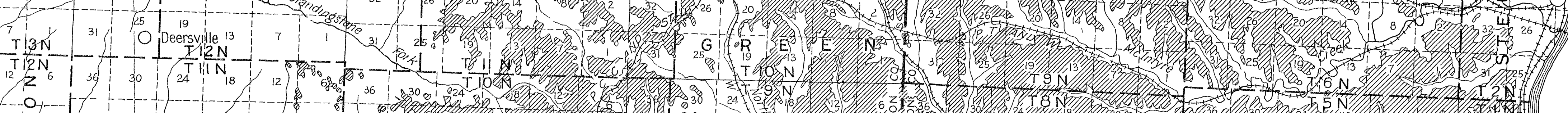
-

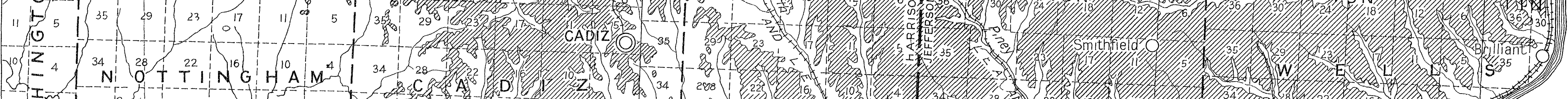
-

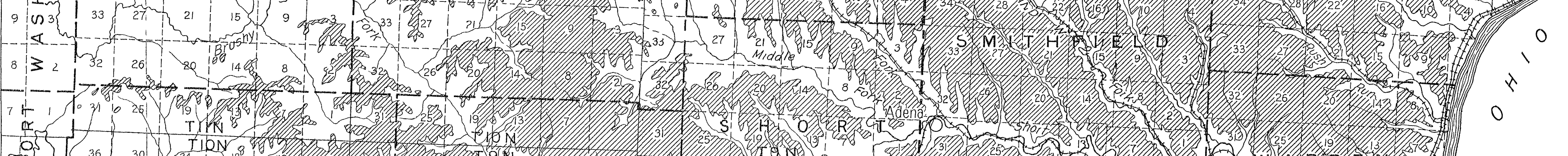

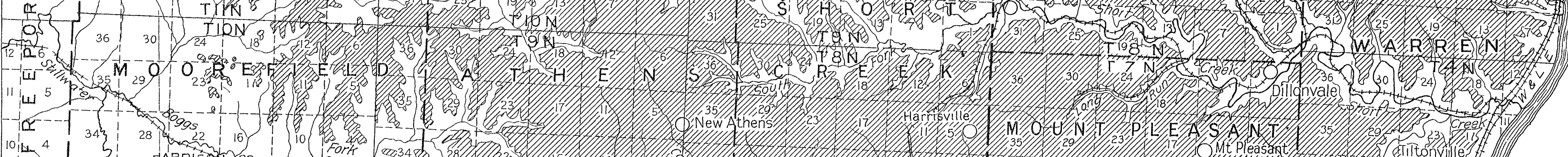

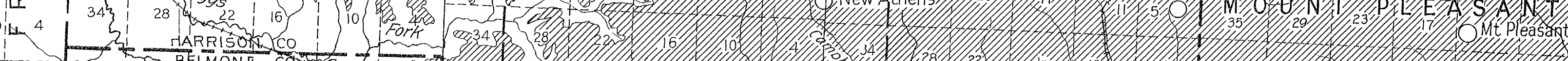

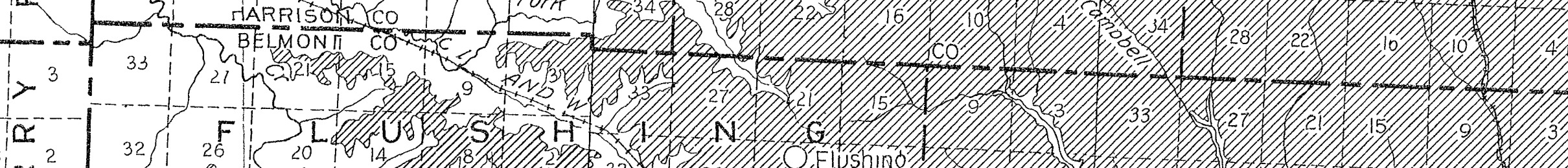

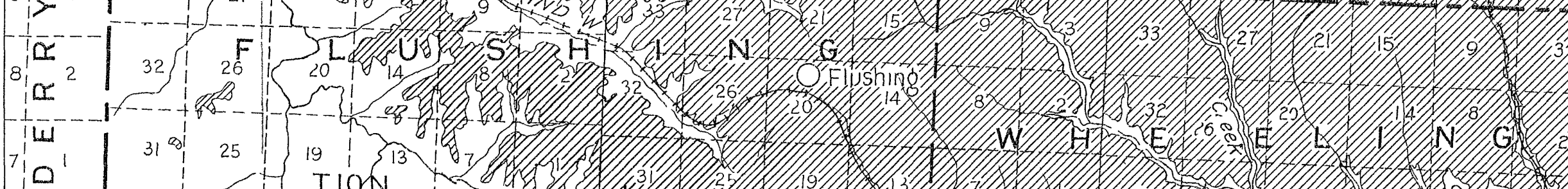

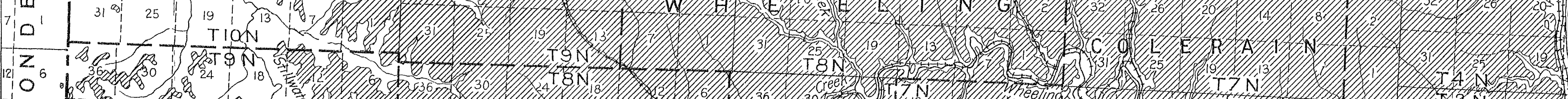

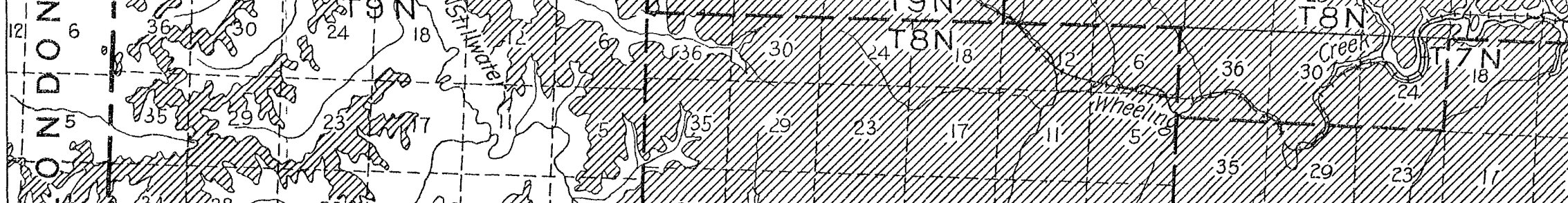

-

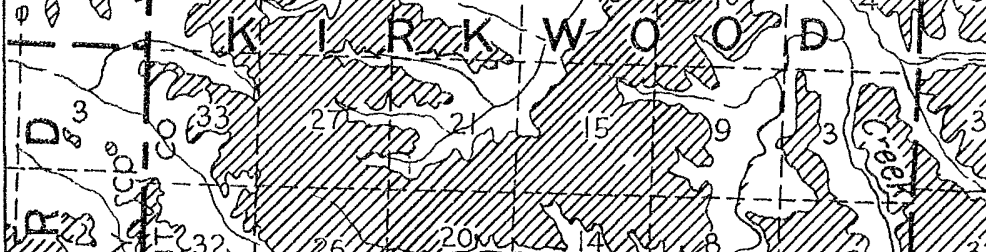

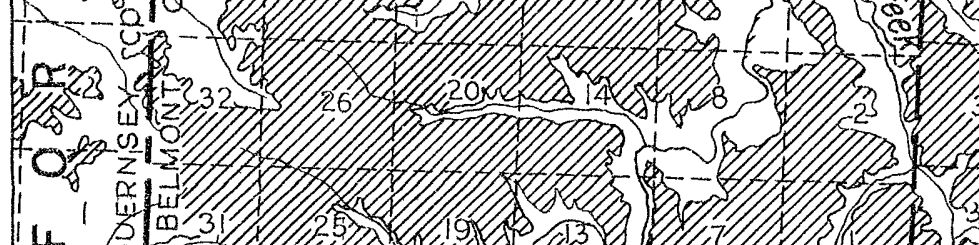

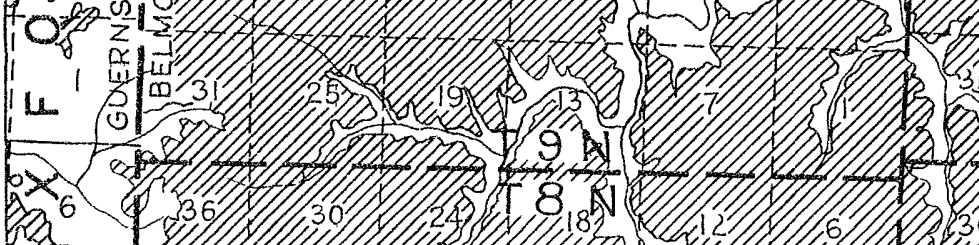

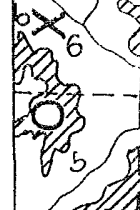

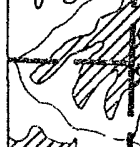

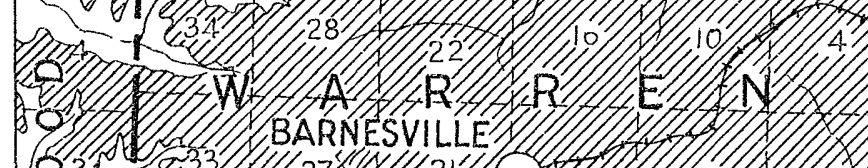

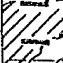
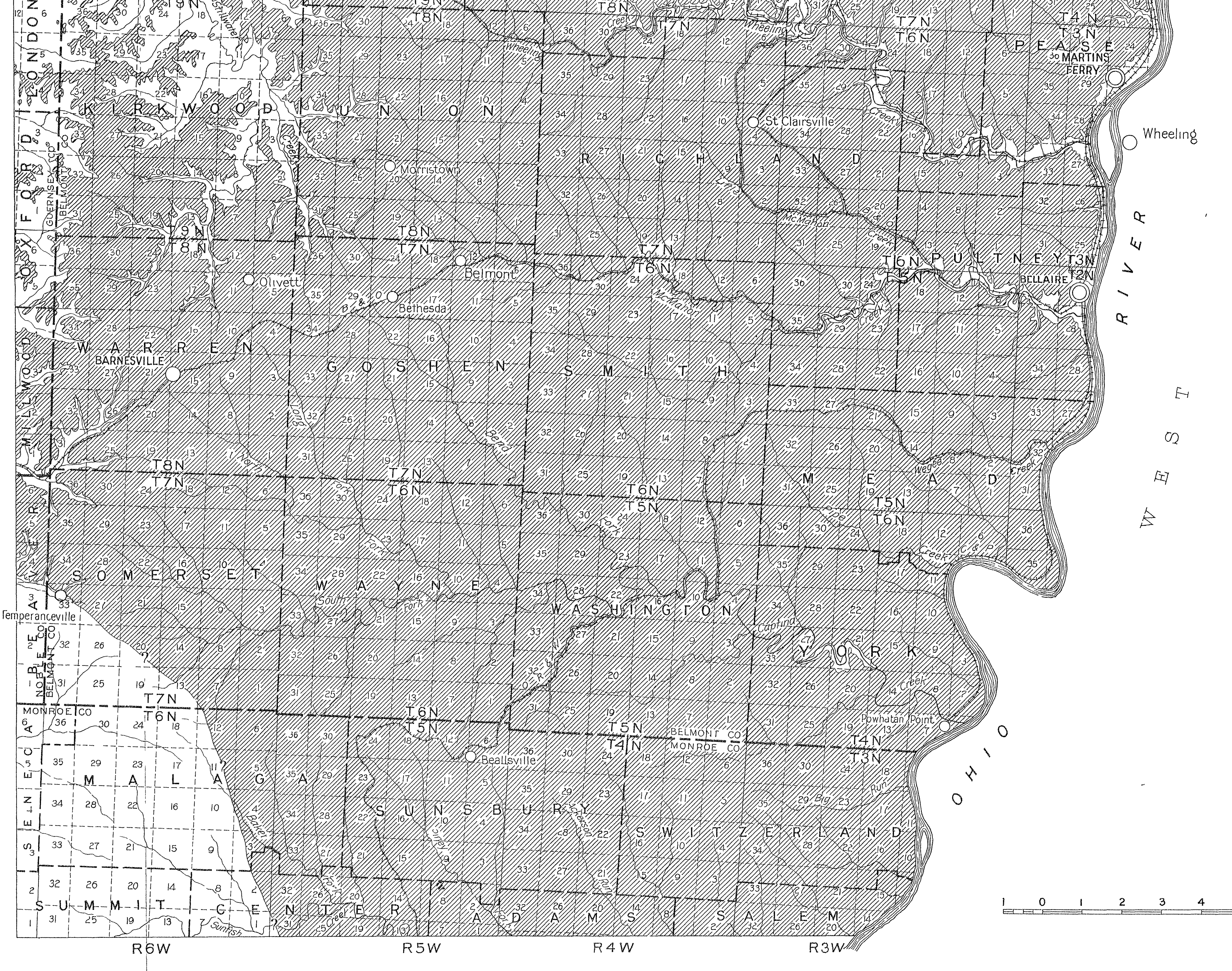

列
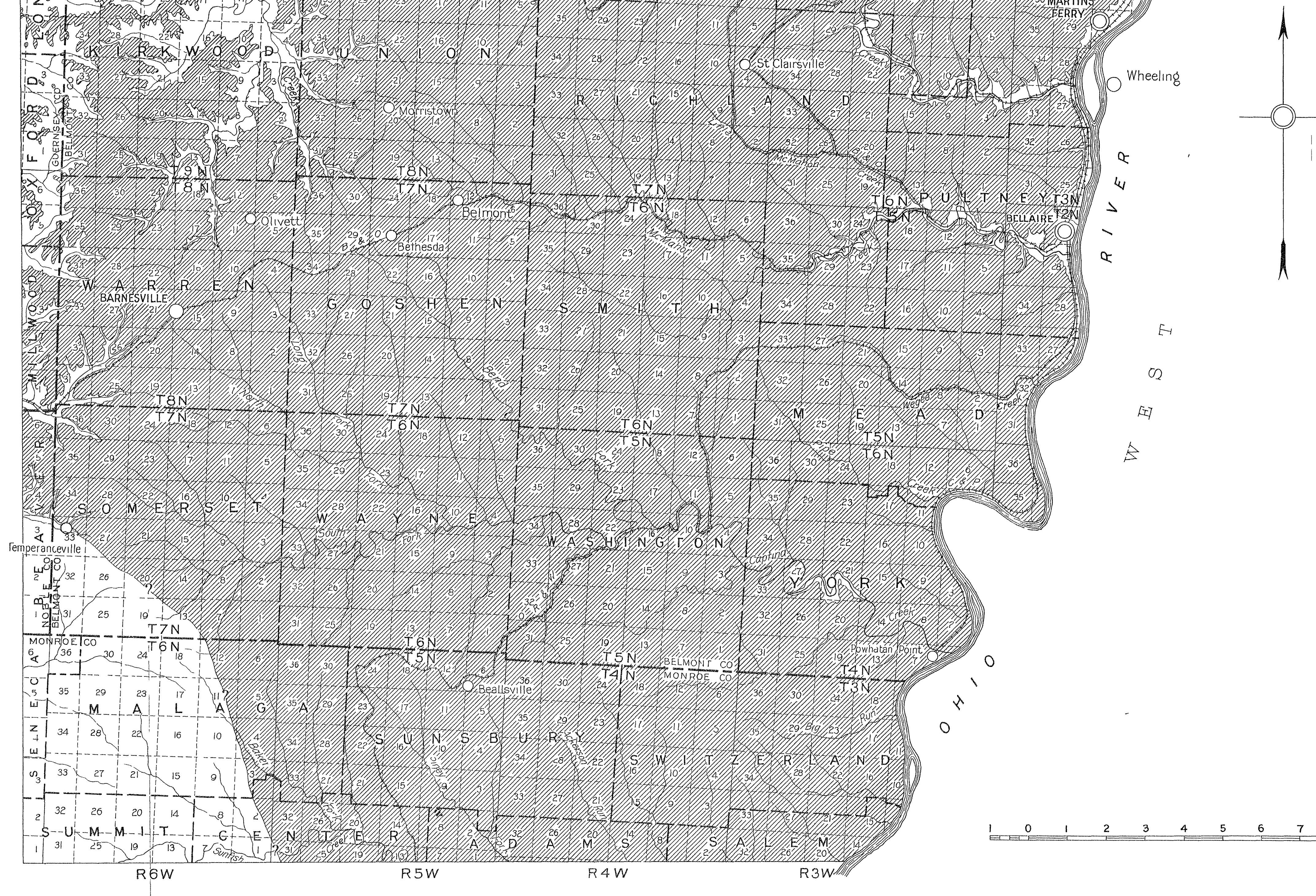
A proximate analysis of a sample from this mine shows moisture 2.9 , volatile matter 37.9 , fixed carbon 51.2 , and ash 8.0 per cent; an ultimate analysis. shows carbon 72.95 , hydrogen 5.11 , oxygen 8.59 , nitrogen 1.04, sulphur 4.31, and ash 8 per cent. The heat value is 13,210 B. t. u.

The "draw slate" is reported to contract in places to an inch and the breast coal to contain in places thin lenses of pyrite. Partings of "smut" not more than one-fourth inch thick werc noted in the lower part of the coal bed. The coal at this place is reported to be on a level with the bed of Ohio River. Three diamonddrill tests, made in secs. 2, 8, and 14, Mead Township, disclosed thicknesses of 5 feet 1 inch,

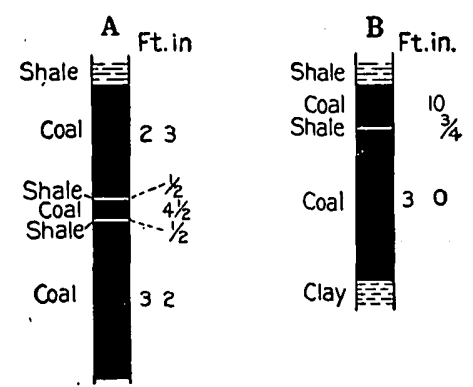

FIGURE 35.-Sections of Pittsburgh (No. 8) coal bed in Belmont County, Ohio. A, Mend Township; B, Somerset Township.

5 feet 5 inches, and 5 feet, respectively, of the Pittsburgh coal bed.

Section of Pittsburgh coal bed in Captina Coal Co.'s mine, Armstrongs Mills, Washington Township, Belmont County, Ohio.

Coal, roof Ft. in.

Coal, bony, rejected .................. 3

Coal, breast, with three thin partings. . ......... 28

Shale. . . . . . ................... 1

Coal, bcaring-in..................... 81

Coal, brick, with several "smut" layers.......... 1. $8 \frac{1}{2}$

Shale................................... $1^{\frac{1}{2}}$

Coal, bottom, with a few pyrite lenses......... $\frac{1}{76 \frac{1}{2}}$

A proximate analysis of a sample from this mine shows moisture 2.8, volatile matter 37.9 , fixed carbon 49.9 , and ash 9.4 per cent; an ultimate analysis shows carbon 69.76 , hydrogen 5.25, oxygen 9.39 , nitrogen 1.09 , sulphur 5.09 , and ash 9.42 per cent. The heat value is 12,990 B. t. u.

This mine is located in the valley of Captina Creek. As its only outlet is a narrow-gage railroad the output is not large. The coal is below drainage everywhere on Captina Creek except near the middle of York Township, where a low anticline brings it above the valley floor.

Section of Pittsburgh coal bed in Jefferies mine Temperanceville, Ohio.

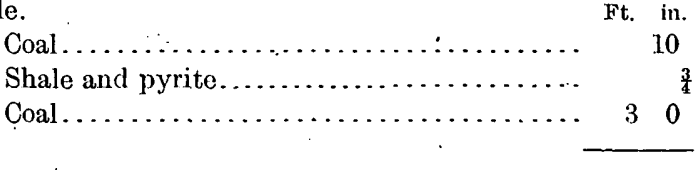

$310 \frac{3}{4}$

A proximate analysis of a sample from this mine shows moisture 4.1, volatile matter 37.1, fixed carbon 48.2, and ash 10.6 per cent; an ultimate analysis shows carbon 68.77 , hydrogen 4.89 , oxygen 9.68 , nitrogen 1.10 , sulphur 4.95 , and ash 10.61 per cent. The heat value is $12,480 \mathrm{~B}$. t. u.

Variations in composition of the Pittsburgh coal from east to west across Belmont County are well shown below:

Variations in Pittsburgh coal in Belmont County, Ohio.

\begin{tabular}{|l|r|r|r|r}
\hline & B.t. u. & Ash. & $\begin{array}{c}\text { Sul- } \\
\text { phur. }\end{array}$ & $\begin{array}{l}\text { Mois- } \\
\text { ture. }\end{array}$ \\
\hline $\begin{array}{c}\text { Eastern border of field, aver- } \\
\text { age of } 10 \text { samples........ }\end{array}$ & 13,000 & 8.1 & 3.74 & 3.6 \\
$\begin{array}{c}\text { Middle field, average of } 6 \\
\text { samples............... }\end{array}$ & 12,650 & 9.0 & 3.35 & 4.8 \\
$\begin{array}{c}\text { Western border of field, } \\
\text { average of 5 samples...... }\end{array}$ & 12500 & 9.9 & 4.02 & 4.8 \\
\hline
\end{tabular}

In air-dried samples the moisture is about 3 per cent.

The coal cokes, but the coke, because of its sulphur content, can not compete with that from Connellsville or. West Virginia. It was formerly coked in the eastern part of Belmont County, but the practice ceased more than 20 years ago. The great use of the coal is for steam and domestic purposes.

Jefferson County.-Jefferson County, which lies north of Belmont, is the second largest producer of coal in Ohio. In 1912 it had an output of 4,858,529 short tons, nearly all of which came from the Pittsburgh bed. As this coal bed rises northward it has been more extensively eroded in Jefferson than in Belmont County, and it is largely restricted to the higher areas. Short Creek, which crosses the field from west to east, and its northwest tributaries have eroded far below the coal bed, and their 
valleys are now utilized by railroads. The coal is abundant as far north as the Pennsylvania - Railroad; but farther north it is restricted to a few hills and ridges, in only one of which it is of sufficient area to be valuable. The structure and composition of the bed is similar to that in Belmont County.

Section of Pittsburgh coal bed in Wheeling \& Lake Erie Coal Mining Co.'s mine No. 2, Dillonvale, Ohio.

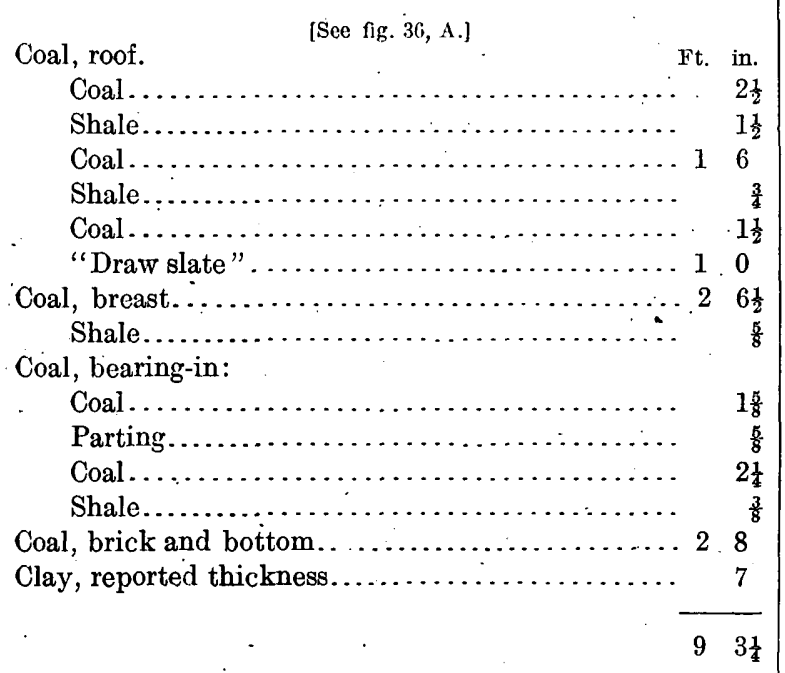

The proximate analysis of a sample from this mine shows moisture $3 . \dot{1}$, volatile matter 37.9 , fixed carbon 49.5 , and ash 9.5 per cent; an ultimate analysis shows carbon 69.56 , hydrogen 5.22, oxygen 10.77 , nitrogen 1.10 , sulphur 3.83 , and ash 9.52 per cent. The heat value is $12,880 \mathrm{~B}$. $t$. $u$.

The mine from which this sample was taken is located in the valley of Short Creek, the most important mining district in the county, and the section given is representative of the coal in that territory. The Ames limestone, of stratigraphic value, lies in the bottom of the valley at Adena, where it is 175 feet below the Pittsburgh coal.

Section of Pittsburgh coal bed in United States Coal Co.'s mine, in extreme northwest corner of Smithfield Tounship, - Jefferson County, Ohio.-

[See fig. 36, B.1.

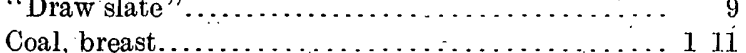

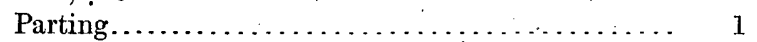

Coal, bearing-in........................... 1

Parting................

Coal, brick and bottom.
A proximate analysis of a sample from this mine shows moisture 4.3, volatile matter 35.3 , fixed carbon 52.5, and ash 7.9 per cent; an ultimate analysis shows carbon 71.34 , hydrogen 5.18 , oxygen 11.39 , nitrogen 1.20 , sulphur 3.01 , and ash 7.88 per cent. The heat value is 12,860 B. t. u.

This mine is near the northern limit of the Pittsburgh coal bed in Jefferson County and

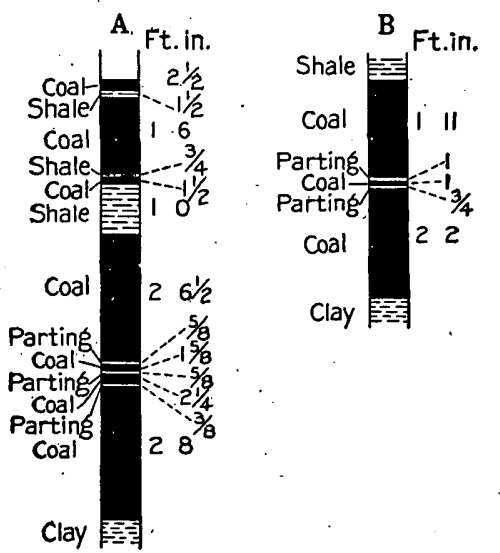

Figure 36.-Sections of Pittsburgh (No. 8) coal bed in Jefierson County, Ohio. A, Mount Pleasant Township; B, Smithfield Township.

shows fair thickness and good quality. Although no lenses of pyrite are indicated in the section, they are common in the mine.

Section of Pittsburgh coal bed in Dewland Cox \& Sons' mine, Brilliant, Ohio.

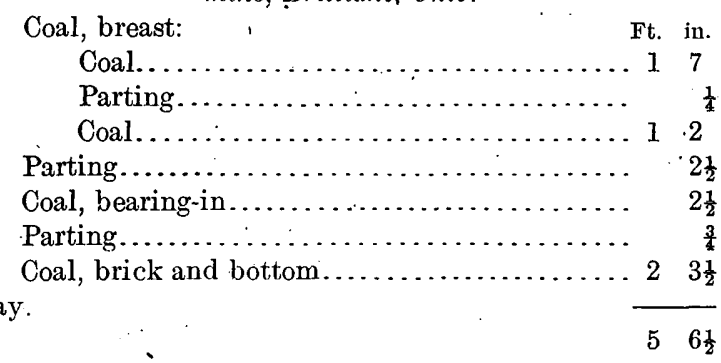

A proximate analysis of a sample from this mine shows moisture $4.9,{ }^{1}$ volatile matter 33.1 , fixed carbon 51.5, and ash 10.5 per cent; an ultimate analysis shows carbon 68.01 , hydrogen 5.03 , oxygen 11.29 , nitrogen 1.12 , sulphur 4.09 , and ash 10.46 per cent. The heat value is 12,520 B. t. u.

The coal bed, as determined by C. N. Brown with a $Y$ level, is 343 feet above the Wheeling \& Lake Erie Railway tracks at Brilliant and

1 Sample was slightly wet. Moisture may possibly be 1 per cent high on this account. 


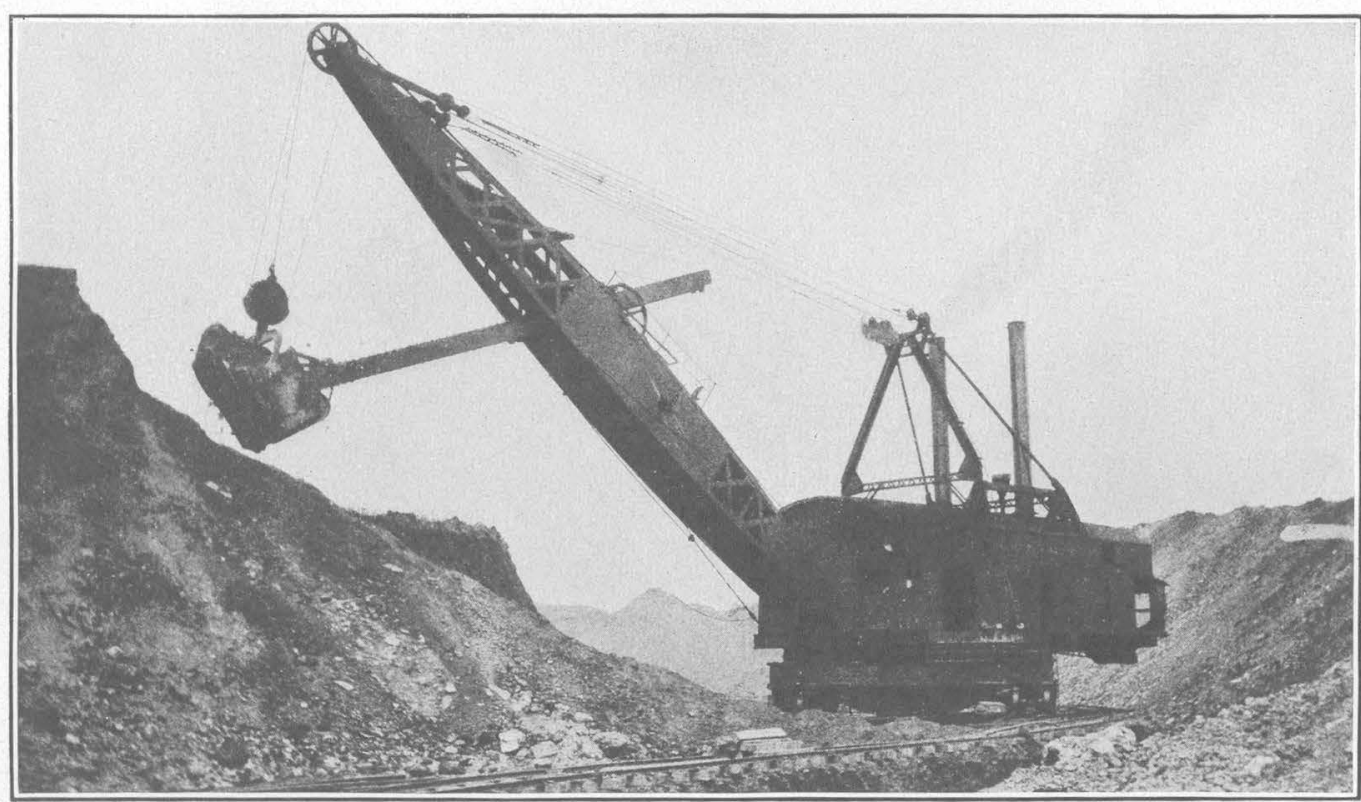

A. STRIPPING PITTSBURGH COAL IN JEFFERSON COUNTY, OHIO, WITH A STEAM SHOVEL.

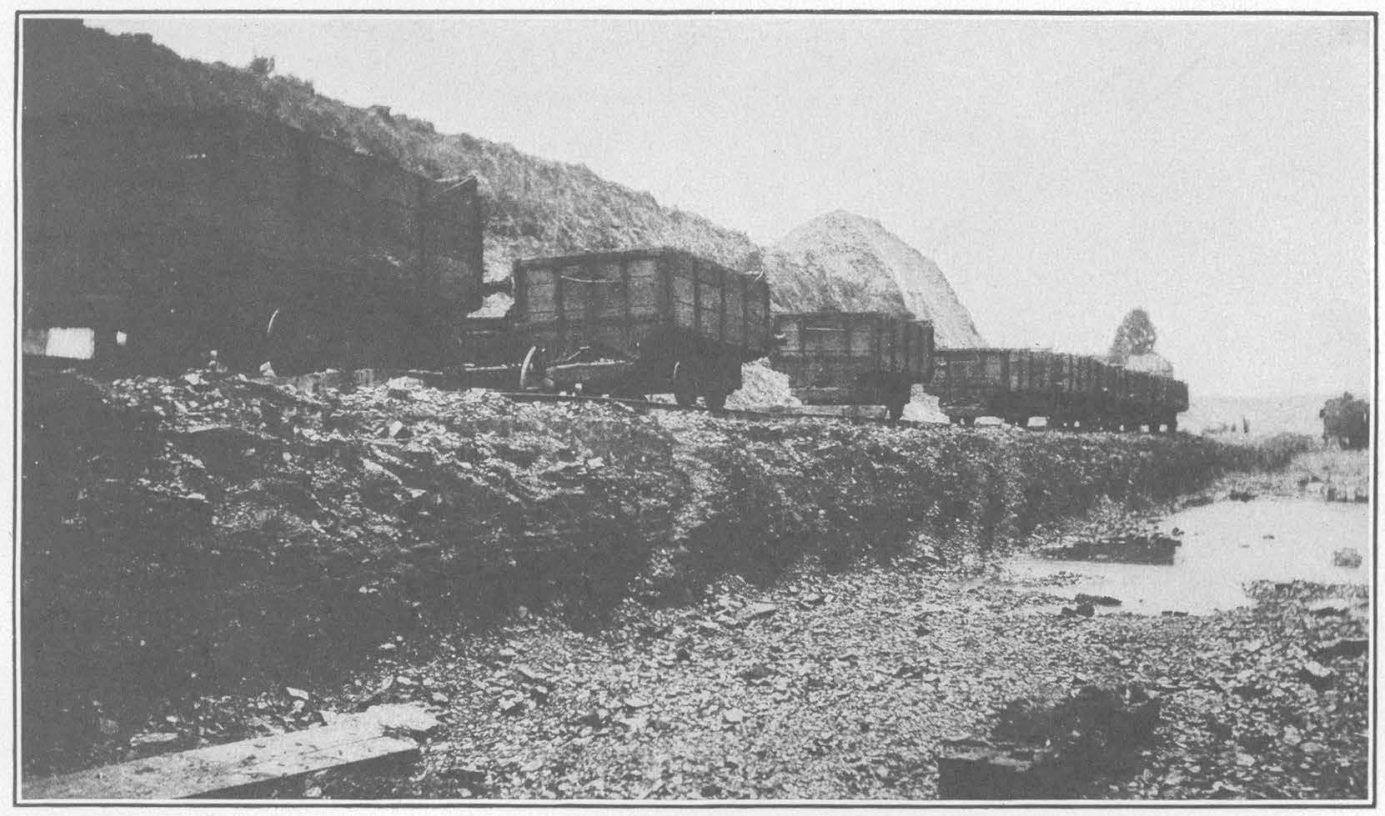

B. SAME STRIP PIT AS SHOWN IN A AFTER OVERBURDEN HAS BEEN REMOVED. 
238 feet above the Ames limestone. At Brilliant this limestone is 5 feet thick and was formerly burned for lime. It is well shown at many places along the Ohio Valley in the southern part of this county and at Portland lies $197 \frac{1}{2}$ feet below the Pittsburgh coal and 75 feet above the railroad tracks.

The Pittsburgh coal is mined by stripping with a steam shovel on the ridge about 2 miles west of Rush Run. (See Pl. VIII, $A, B$.) On the average about 25 feet of shale overburden is removed. The coal, 5 feet thick, is then shot and loaded on cars with a smaller steam shovel. This bed is stripped at Witch Hazel also, and preparations are under way for work of this kind at two other places in the county.

Harrison County. - The Pittsburgh coal bed underlies the hills and ridges in the eastern half of Harrison County, but its larger areas are restricted to the southeastern townships-Short Creek, Green, Cadiz, and Athens. Everywhere it is high in the hills; even in the southeast corner of the county, where it is lowest, it is approximately 175 feet above the valley. Shipping mines are few and are restricted to two townships. Everywhere the coal bed has the structure characteristic of the Pittsburgh bed in the type locality, and it is everywhere of workable thickness.

Section of Pittsburgh coal bed in mine on S. P. Dunlap farm, northwest corner of Short Creek Township, Harrison County, Ohio.

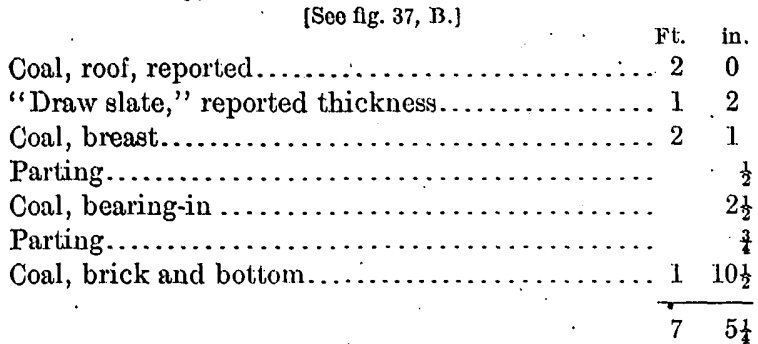

A proximate analysis of a sample from this mine shows moisture 6.5 , volatile matter 35.5 , fixed carbon 51.3 , and ash 6.7 per cent; an ultimate analysis gives carbon 70.49 , hydrogen 5.70 , oxygen 13.66 , nitrogen 1.22 , sulphur 2.19 , and ash 6.74 per cent. The heat value is $12,710 \mathrm{~B}$. t. u.

A mine in the northeast part of Short Creek Township shows 4 feet 6 inches of coal with a heat value of 12,890 B. t. u. Athens Township, which lies west of Short Creek Township, forms the divide between east-flowing and west-flowing streams, and hence has a large area of coal.

Section of Pittsburgh coal bed in mine on John Edwards farm, NE. + sec. 1, Athens Township, Harrison County, Ohio.

\begin{tabular}{|c|c|}
\hline & Ft. \\
\hline Coal, roof .. & 10 \\
\hline Clay, "Draw slate". & 10 \\
\hline 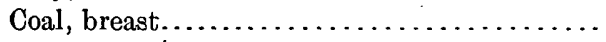 & .2 \\
\hline Coal, bearing-in (coal and shale) $\ldots \ldots \ldots \ldots \ldots$ & 2 \\
\hline Coal, brick. ${ }, \ldots \ldots \ldots \ldots \ldots \ldots \ldots$ & . $1 \cdot 3$ \\
\hline 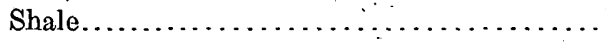 & $\frac{1}{1}$ \\
\hline 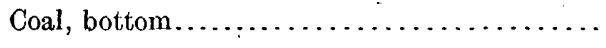 & 1 \\
\hline & 6 \\
\hline
\end{tabular}

A proximate analysis of a sample from this mine shows moisture 6 , volatile matter 34.3 ,

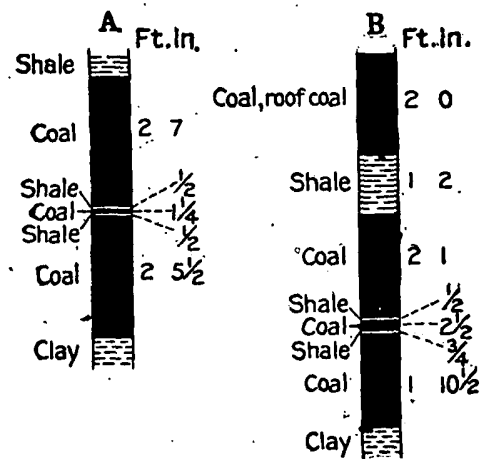

FIaURe 37.-Sections of Pittsburgh (No. 8) coal bed in Ohio. A, Warren Township, Jefferson County; B, Short Creek Township, Harrison County.

fixed carbon 53.7, and ash 6 per cent; an ultimate analysis gives carbon 72.22 , hydrogen 5.44, oxygen 13.71, nitrogen 1.31, sulphur 1.35 , and ash 5.97 per cent. The heat value is 12,960 B. t. u.

Although this section shows only 4 feet $3 \frac{1}{2}$ inches of coal, excluding the roof, the quality. is good and the township will become in the near future a large producer. The Meigs Creek coal bed, in good thickness and quality, is also present where due.

Cadiz Township lies north of Athens and has the Pittsburgh coal bed only in the hills and ridges. The coal is worked on several farms, but nowhere for railroad shipment. 


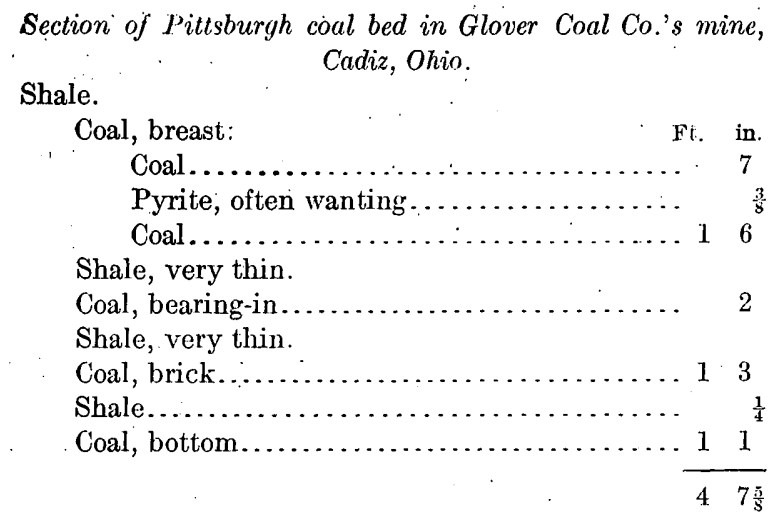

A proximate analysis of a sample from this mine shows moisture 3.8 , volatile matter 36.7 , fixed carbon 48.6 , and ash 10.9 per cent; an ultimate analysis gives carbon 67.70 , hydrogen 5.09 , oxygen 10.68 , nitrogen 1.27 , sulphur 4.38 , and ash 10.88 per cent. The heat value is 12,360 B. t. u.

The coal bed in Green and German townships has the charactei istic Pittsburgh structure and is about 4 feet thick. 'The outlying hills and ridges contain a supply of coal that is valuable for farmers, as railroads are in places miles distant.

Guernsey and Noble counties.-The' area of Pittsburgh coal in Guernsey and Noble counties is small and is practically restricted to the two ridges north and south of Leatherwood Creek. In the ridge just north of Quaker City C. N. Brown found the coal bed 190 feet above the Ames limestone and 'measured the following section:

Section of Pittshurgh coal bed north of Quaker City, Ohio.

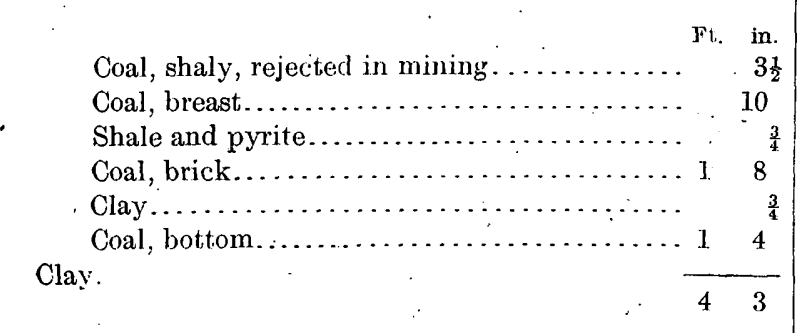

It will be noted that the bed has the characteristic section of the Pittsburgh bed, except that the "bearing-in" coal is represented by a thin layer of shale and pyrite. The "breast" coal, however, is abnormally thin as compared with the type section but has about the thickness that prevails along the extreme western border of the field.
In Noble County the area of Pittsburgh coal of workable thickness is very small and is limited to the northeast quarter of Beaver Township, where in a few places it is mined by farmers.

Muskingum County.-The Pittsburgh coal is found in the high hills in the southeast part of Muskingum County, where in places it attains a thickness of 30 inches and is divided into two parts by a few inches of clay or shale. It. can never be a source of fuel except for local purposes.

Monroe County.-The Pittsburgh coal outcrops in the northwest part of Monroe County but appears to be too thin to mine west of sec. 24, Małaga Township.

The coal is known to be present in the southern part of Belmont County and in West Virginia, as far south at least as Proctor, where the bed is nearly 6 feet thick. This indicates that the coal is probably present in the northeastern part of Monroe County, and in fact it has been reported by many oil drillers, and what is more important, by diamond-drill tests.

Thicknesses of coal penetrated by diamond drill in northeastern Monroe County, Ohio.

Sunsbury Township, sec. $35 \ldots$ Ft. in.

Switzerland Township, sec. $28 \ldots \ldots \ldots \ldots \ldots \ldots \ldots 5$

Salem Township, séc. $32 \ldots \ldots \ldots \ldots \ldots \ldots \ldots 58$

The Pittsburgh coal is probably present in workable thickness north of a line drawn from sec. 24, Malaga Township, through Woodsfield to Proctor on Ohio River, but coal lands in this area should never be purchased without careful exploration with the drill.

AREA BETWEEN BELMON'T AND FEDERAL CREEK FIELDS,

The Pittsburgh coal bed between the Belmont and Federal Creek fields is generally less than a foot thick and in places is represented by a black streak only. As already stated, the Belmont field extends into the northeast corner of Noble County, but elsewhere in this county the coal bed is thin and probably worthless. In Meigsville Township, Morgan County, it attains a maximum thickness of 2 feet 6 inches and 18 inches in Bristol and Bloom townships; southwest of Muskingum. River it is thinner and is usually represented by nothing more than a black streak, until the 
Federal Creek field is reached. In northern Washington County the Pittsburgh coal ranges usually from 2 to $2 \frac{1}{2}$ feet in thickness in an area lying mainly in Salem Township (where it is at its best) and in Liberty and Ludlow townships. It is known locally as the Salem or Limestone coal. It has been mined to a very small extent by farmers, but can never be an important source of fuel.

$$
\text { FEDERAL CREEK FIELD. }
$$

The Federal Creek field lies in Homer and Marion townships, in the southwest corner of Morgan County, and in Ames, Berne, and Rome townships; in the northeast part of Athens County. Under cover the coal bed extends for an undetermined distance over the line into Washington County. The length. of the field above drainage is approximately 15 miles in a northwest-southeast direction, and its average width less than 3 miles. The field is drained by Federal Creek, and the topography is rough. Eastward and westward the caal bed thins abruptly and becomes worthless.

The section of the bed is markedly different from that in the Belmont field. It consists usually of two prominent benches soparated by a thick layer of. clay. Each bench usually contains one or more shale partings, and the top bench commonly has from a fow inches to a foot or even more of bony coal. These-characters are well shown in the sections below.

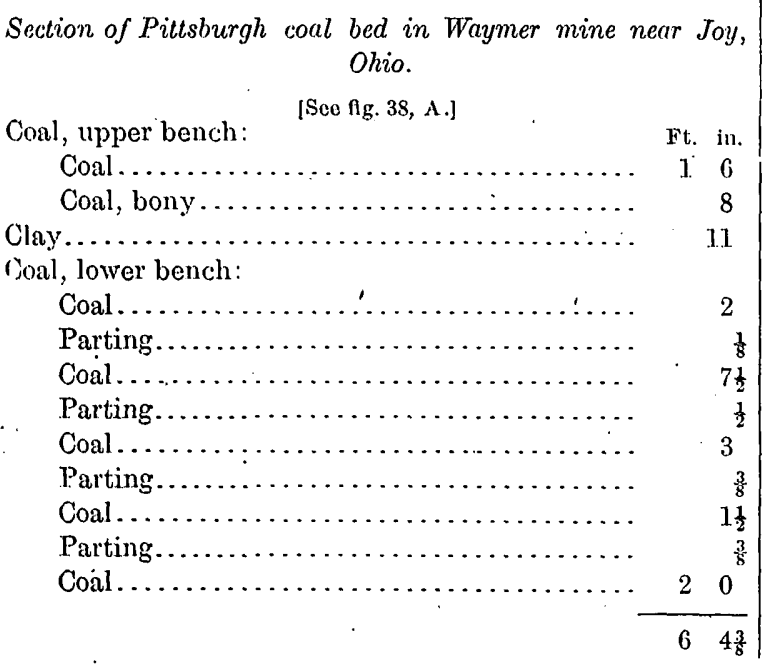

A proximate analysis of a sample from this mine shows moisture 6.9 , volatile mátter 40.5 , fixed carbon 44.4, and ash 8.2 per cent; an ultimate analysis shows carbon 67.39 , hydrogen

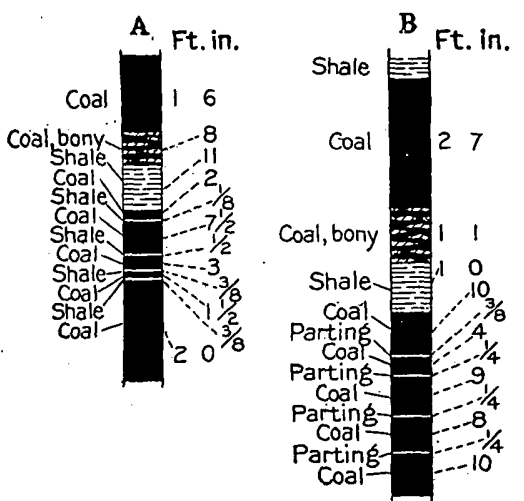

FiguRe 38.-Sections of Pittsburgh (No. 8) coal bed in Ohio. A, Homer Township, Morgan County; B, Berne Township, $A$ thens County.

5.32, oxygen 13.98 , nitrogen 0.90 , sulphur 4.22 , and ash 8.19 per cent. The heat value is 12,100 B. t. u.

Section of Pittsburgh coal bed in Black Diamond Coal \& Coke Co.'s mine, Lathrop, Ohio.

[Sce fig. 38, B.]

Shale.

Coal, upper bench:

Coal........................... 7

Coal, bony ...................... 11

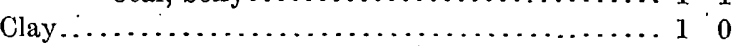

Coal, lower bench:

Coal................................. 10

Parting................................

Coal................................. 4

Parting............................

Coal.............................. 9

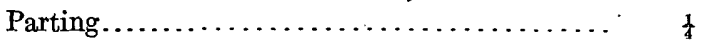

Coal.:............................. 8

Pärting.....................

Clay.

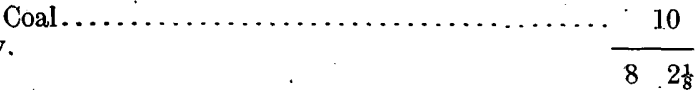

A proximate analysis of a sample from this mine shows moisture 5.8, volatile matter 37.4 , fixed carbon 48.8 , and ash 8 per cent; an ultimate analysis gives carbon 67.55 , hydrogen 5.14 , oxygen 14.17 , nitrogen 0.95 , sulphur 4.19 , and ash 8 per cent. The heat value is 12,300 B. t. u. 
Section of Pittsburgh coal bed in Federal Coal Co.'s mine, Broadwell, Ohio.

Coal, upper bench: ........................... 3

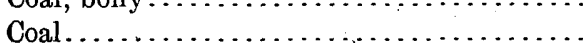

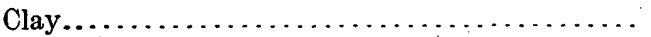

Coal, lower bench:

Coal..............................

Parting..............................

Coal...............................

Parting

Clay.

(n)

$511 \frac{5}{8}$

A proximate analysis of a sample from this mine shows moisture 6.6 , volatile matter 35.1 , fixed carbon 48.1, and ash 10.2 per cent; an ultimate analysis gives carbon 66.61 , hydrogen 5.13 , oxygen 13.72 , nitrogen 0.93 , sulphur 3.41 , and ash 10.20 per cent. The heat value is 11,890 B. t. u.

For comparison with the Pittsburgh coal in other fields, the following percentages, which are the averages of three analyses of samples from different parts of the field, are given: Ash 8.8, sulphur 3.94 , moisture 6.4 per cent, and heat value 12,100 B. t. u.; moisture in air-dried samples about 3 per cent.

The Pittsburgh coal in this field is less regular in thickness than it is in the Belmont field, and in places the lower bench alone is present. Both benches, especially the upper, contain boulders of sandstone or sandstone with pyrite which range from pebbles to masses weighing a ton or even more. Their shape is roughly spherical, oval, or flat. The coal has been coked at two places. At Utley 125 ovens were built, but all of these were not in operation at. one time and are now in ruins. At Lathrop there were 50 ovens, but these have not been active for many years. The coke is said to have had a ready market, but the industry failed for lack of transportation facilities. During the past few years five shipping mines have been in operation.

The Pittsburgh coal attains workable thickness in Alexander and Lodi townships in the southern part of Athens County and in the adjacent townships, Scipio and Bedford, in Meigs County. In some places the lower bench alone is found, but elsewhere both benches are present. In places the coal reaches 4 feet in thickness, but much more commonly its maximum is 3 feet, and it thickens and thins sharply.
Sandstone boulders in the coal are common. The most that can be said for this field is that it may meet a local demand from farmers. From this area south to Ohio River the Pittsburgh coal bed is generally absent.

SWAN CREEK FIELD.

The Swan Creek field of the Pittsburgh coal lies south of Gallipolis in the eastern part of Gallia County and includes parts of Clay, Ohio, Guyan, Harrison, and Green townships. The north part of the field is drained by Raccoon Creek and its tributaries and the south part by Swan Creek, from which the field is named. The surface is very rough, and the area has no shipping facilities except Ohio River, which has been utilized to a small extent. The section of the bed varies. In Ohio, Clay, and Guyan townships the coal bed usually consists of two benches separated by a bed of
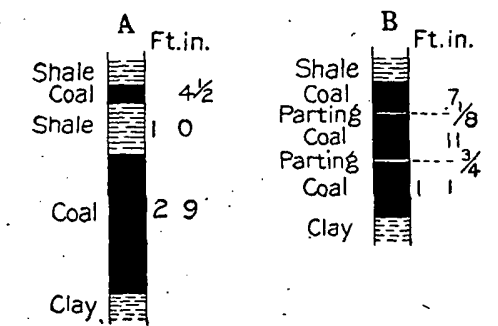

Figure 39.-Sections of Pittsburgh (No. 8) coal bed in Gallia County, Ohio. A, Ohio Township; B, Green Township.

shale, which ranges from 8 to 24 inches in thickness. The upper bench is thinner and less constant than it is farther north. This section is strikingly similar to that in the Federal Creek field. In Harrison and Green townships the bed is more complex and the shale parting thinner.

Section of the Pittsburgh coal bed in the Swan Creek Coal Co.'s mine near Bladen, Ohio.

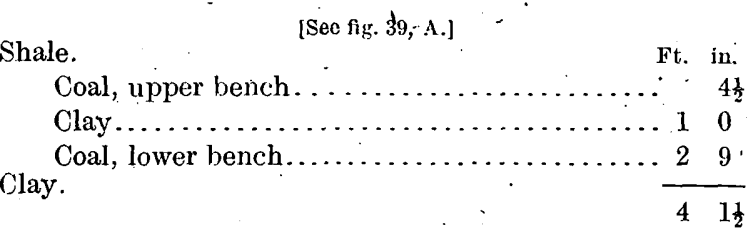

A proximate analysis of a sample from this mine shows moisture 5.8, volatile matter 36.7 , fixed carbon 47.4, and ash 10.1 per cent; an ultimate analysis gives carbon 64.94 , hydrogen 5.16 , oxygen 14.40 , nitrogen 1.10 , sulphur 4.34, and ash 10.06 per cent. The heat value is $11,790 \mathrm{~B}$. t. $u$. 
Scction of the Pittsburgh coal bed in the Kerns mine in sec. 27, Harrison Township, Gallia County, Ohio.

Coal, upper bench: Coal............................ 2 Coal, impure.....................

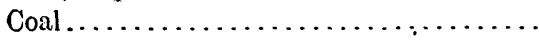

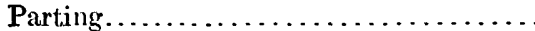

Parting:

Coal..............................

$$
\text { Pyrite }
$$
Pyrite.

Coal, lower bench

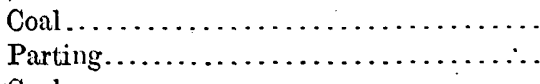

Clay.

$$
\begin{array}{ll}
\cdots & 10^{\frac{1}{4}} \\
\hline 5 \cdot 10 \frac{3}{5}
\end{array}
$$

A proximate analysis of a sample from this mine shows moisture 7 , volatile matter 36.1 , fixed carbon 47.9 , and ash 9 per cent; an ulti-

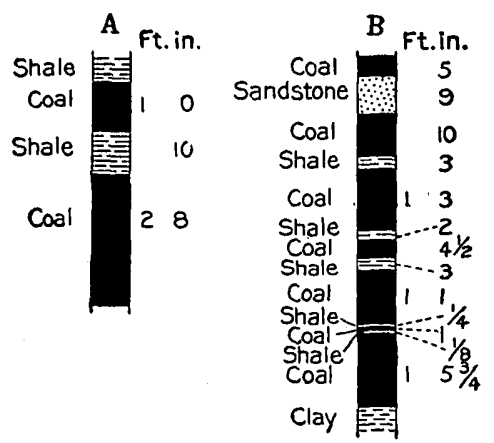

Fiaure 40.-Sections of Pittsburgh (No. 8) coal bed in Gallia County, Ohin. $\Lambda$, Guyan Township; B, Harrison Township.

mate analysis gives carbon 64.91, hydrogen 5.24, oxygen 14.60 , nitrogen 1.01 , sulphur 5.21, and ash 9.03 per cent. The heat value is 11,860 B. t. $u$. Another section measured in Harrison Township is shown in figure 40, B; a section in Green Township in figure 39, B; and one in Guyan Township in figure 40, A.

An average of four analyses of samples from this field gives the following composition: Ash 10.5 , sulphur 4.45 , moisture 6.8 per cent, and heat value 11,720 B. t. u. ; moisture in air-dried sample is about 3 per cent.

The best-known and largest producing mine in this field is that of the Swan Creek Coal Co. near Bladen on the bank of Ohio River. It ships the coal on barges and is the only mine in the field to do so. The field is without railroad connections, and this makes large development impossible. For many years coal has been hauled in wagons from the upper end of the field to Gallipolis, which obtains much of its coal supply in this way. The principal mines, in addition to the one on the bank of Ohio River, are in the valley of Swan Creek and on Raccoon Creek and its principal tributaries, Teens Run and Big Bullskin Creek.
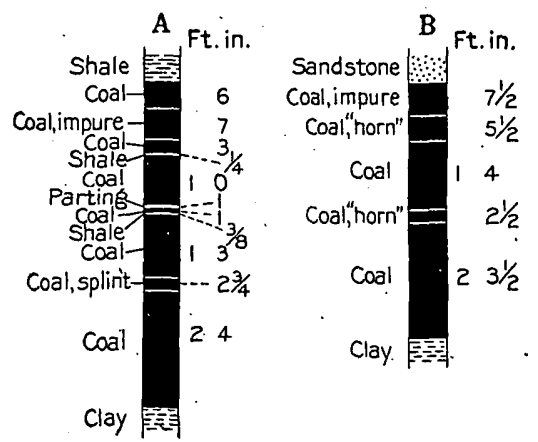

Figure 41.-Sections of Pomeroy (No. 8a) coal bed in Meigs County, Ohio. A, Rutland Township; B, Sutton Township.

POMEROY (NO. 8a) COAL BED.

The Pomeroy (No. 8a) coal was long regarded as the Pittsburgh bed. Its true position was not demonstrated until 1908, when work, primarily by Condit, showed it to lie at the horizon of the Redstone bed of Pennsylvania and West Virginia.

The coal bed commonly lies 20 to 55 feet above the Pittsburgh, from which it is separated by a bed of limestone that is more persistent than the Pittsburgh coal itself.
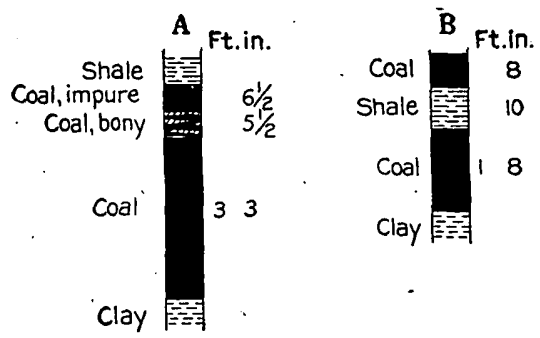

Figure 42.-Sections of Pomeroy (No. 8a) coal hed in Gallia and Meigs counties, Ohio. A, Salisbury Township, Gallia County; B, Bedford Township, Meigs County.

The Pomeroy bed is found in the hills opposite Wheeling, W. Va., and can be followed southwest to Lawrence County, but it has little or no value outside of Meigs County. ' (See Pl. IX.) Its best development is in Salisbury Township (see fig. 42, A) and three or four other townships which border on Ohio River and form the Pomeroy field. The field is thus small but may be extended markedly on the east, where the coal is below drainage. In the northern part of Salisbury Township and in 
Bedford Township the bed is less than 2 feet thick, as shown in figure $42, \mathrm{~B}$, but it expands in a short distance to the south and has long been mined on a large scale at Pomeroy. It was early used in the salt furnaces and was later shipped by river and still later by rail.

Although the Pomeroy coal is of workable thickness in Meigs, Gallia, and Lawrence counties, it is thickest in Meigs, in which all the railroad mines, with one exception, are situated. The thickness of the bed and the quality of the coal are shown in figure 41, B, and also in the following section:

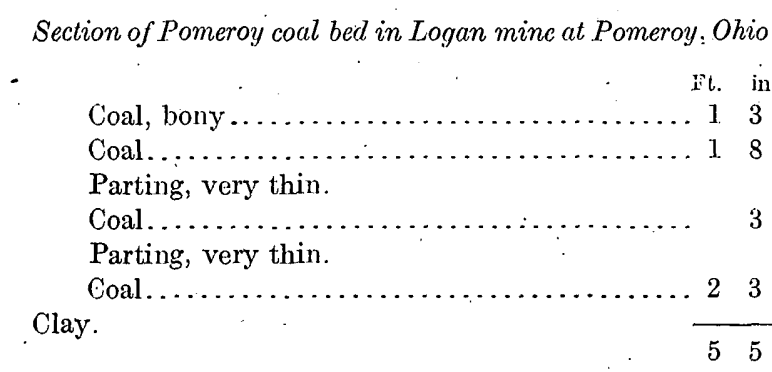

A proximate analysis of a sample from this mine shows moisture 7.2 , volatile matter 32.8 , fixed carbon 50.7, and ash 9.3 per cent; an ultimate analysis gives carbon 66.47 , hydrogen 5.39 , oxygen 16.43 , nitrogen 1.10 , sulphur 1.32 , and ash 9.29 per cent. The heat value is 12,000 B. t. u.

Section of Pomeroy coal bed in Maynard Bros.' mine, near Rutland, Ohio.

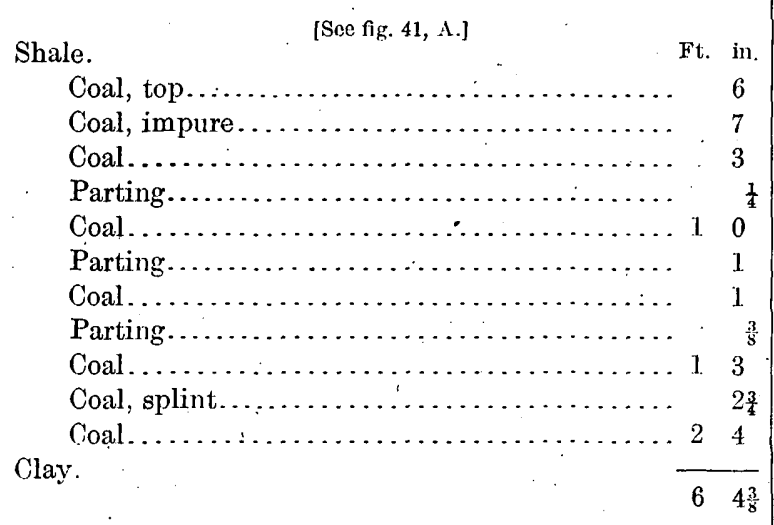

A proximate analysis of a sample from this mine shows moisture 7.6, volatile matter 33.4, fixed carbon 48.1 , and ash 10.9 per cent, and an ultimate analysis gives carbon 65.29 , hydrogen 5.20 , oxygen 15.72 , nitrogen 1.03 , sulphur 1.83 , and ash 10.93 per cent. Its heat value is 11,720 B. t. u. The average of five analyses gives ash 10.4, sulphur 2.46, moisture 6.5 per cent; heat value 11,950 B. t. u. ; the moisture in the air-dried sample is about 4 per cent.

The coal dips below drainage on Ohio River a short distance above Pomeroy. At Syracuse it is 80 feet below the flood plain, and eastward its presence in workable thickness has been demonstrated only by the drill.

Southwest from the Pomeroy field, the coal bed thins and rises in the hills and has been extensively eroded as far as Raccoon Creek in Gallia County. Throughout this area the coal is commonly 2 to 4 feet thick, as shown in figure $43, A$, and has been mined in a small way on many farms. South of Raccoon Creek the Pomeroy coal has been less eroded and under-

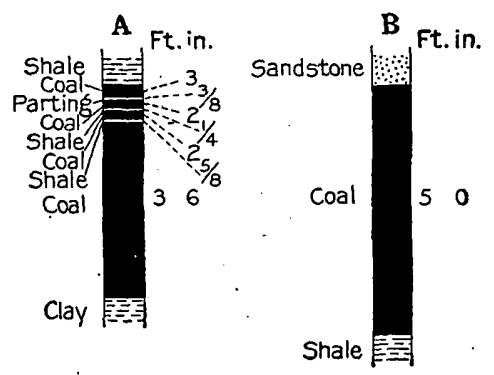

FIgure 43.-Sections of Porreroy (No. 8a) coal bed in Ohio. A, Cheshire Township, Gallia County; B, Mason Township, Lawrence County.

lies a large part of the extreme southern area of Gallia County and the adjacent part of Lawrence County. Its western limit is on Greasy Ridge in the eastern part of Lawrence County, where it attains a thickness of 5 feet, as shown in figure $43, \mathrm{~B}$, and is an important source of fuel among the farmers. East of Greasy Ridge the coal attains in places a thickness of 2 feet to 3 feet 6 inches, but throughout most of the territory it is thinner and at present is of no value. Manifestly the Pomeroy coal in its southwest extension can never be more than a source of fuel for the residents of that region.

MEIGS CREEK (NO. 9) COAL BED.

General features.-The Meigs Creek (No. 9) coal, the highest of the important beds in, the geologic column of Ohio, was named by C. N. Brown from a stream in Morgan County that drains an area in which this coal bed is well developed. It lies 80 to 100 feet above the Pittsburgh coal and is therefore easily identified. The Sewickley bed of Pennsylvania and West Virginia is its equivalent.

Although the Meigs coal bed is due all the way from Jefferson County southwest to Gallia 


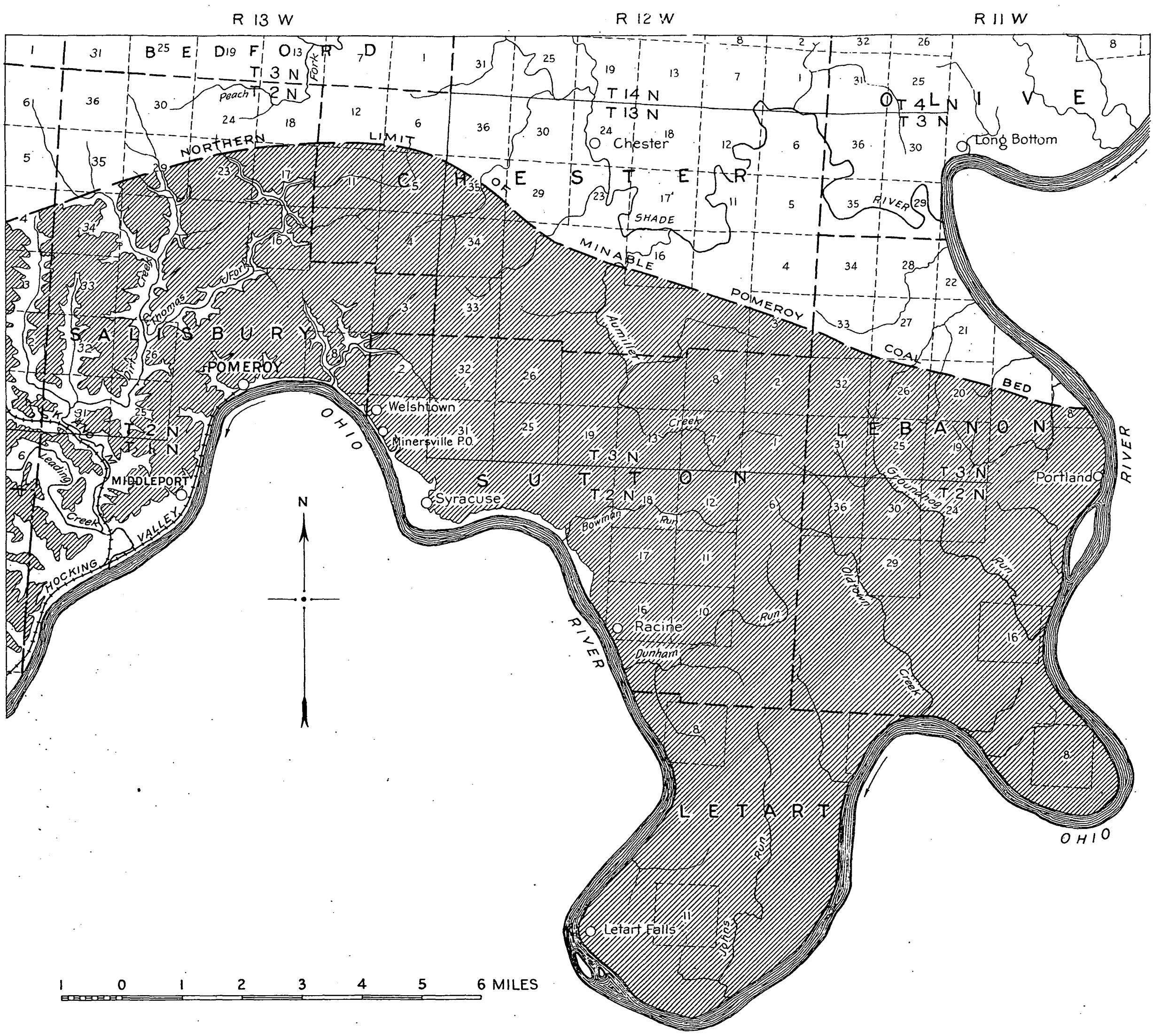

MAP OF THE POMEROY COAL FIELD (POMEROY OR NO. 8a COAL BED), SOUTHEASTERN OHIO By F. A. Ray and D. Dale Condit 
County it is of workable thickness in Belmont, or two stations along the narrow-gage road in Harrison; Monroe, Washington, Noble, and Mor- Noble County, from which the coal is shipped gan counties only, and even in these counties in this way.

it is in places wanting. It has no characteristic structure such as that possessed by the Pittsburgh and Middle Kittanning beds. In places it consists of a solid block of coal, but more commonly it contains one or more clay, shale, or pyrite partings. Both floor and roof are irregular, rising or falling, and thus modifying its thickness. Especially is this true of the roof, which. in places cuts out the coal entirely.

Belmont County.-Belmont County, which contains a larger area of this coal bed than any other county in Ohio, is underlain with the bed, except in the northwest corner, where the hills are not high enough; in the southwest part, where the coal has been swept away in the valleys; in the northeast corner, where the coal, though due, is absent; and along Wheeling, McMahon, and Captina creeks, which have cut their valleys below the horizon of this bed. The following section, measured by J. E. Hyde, near Bellaire, shows the Meigs Creek coal bed and its position with reference to other beds below:

Section of Meigs Creek coul bed and underlying rocks, near

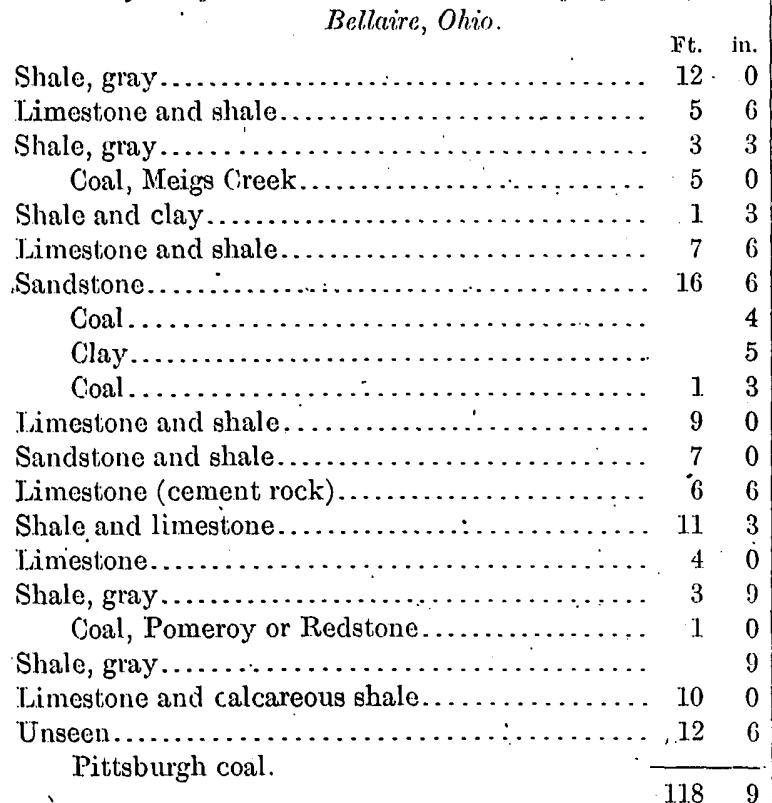

The coal has been mined for railroad shipment for nearly 35 years at Flushing, in northern Belmont County, the only place, except one
Section of Meigs Creek coal bed in Flushing Coal Co.'s mine, Flushing, Ohio.

[See fig. 44, A.]

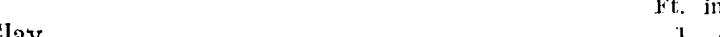

Clay.

3.10

52

A proximate analysis of a sample from this mine shows moisture 5, volatile matter 33.3, fixed carbon 48.9 , and ash 12.8 per cent; an ultimate analysis shows carbon 66.31 , hydrogen 4.95 , oxygen 12.32 , nitrogen 1.19 , sulphur 2.41 , and ash 12.82 per cent. Its heat value is 11,970 B. t. u.

The bed is known locally as the "Four-foot" coal, but it does not average that much. Nodules of pyrite are common and have to be

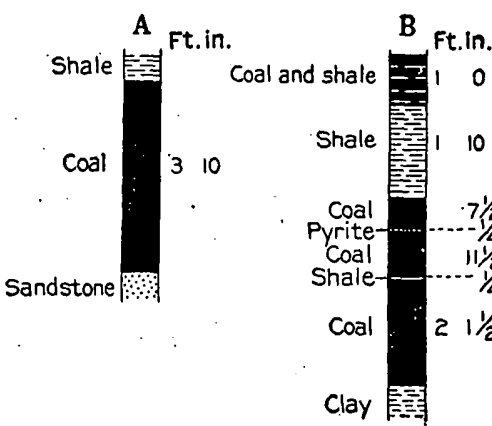

Figure 44.-Sections of Meigs Creek (No 9) coal bed in Belmont County, Ohio. A, Flushing; B, Warren Township.

thrown out by the miners. Many farmers in the township have opened mines on their land for a local supply. In Wheeling Township, which lies east of Flushing, the coal bed is similar in thickness and is found where due, but in Colerain Township the bed thins and is of little or no value. Pease Township, forming the northeast corner of the county, is without the Meigs Creek coal bed, though this bed should be present everywhere in the hills. An interesting point is that as the Meigs Creek coal thins the higher beds thicken and become of value as a source of fuel for the farmers.

In an east-west belt, which includes the townships across the middle of the county, the coal bed is usually of workable thickness where it outcrops, but throughout large areas it lies below drainage. 
Section of Meigs Creek coal bed in Malden mine, Barnesville, Ohio:

[See fig. 44, B.]

Shale and coal, "roof coal" $\ldots \ldots \ldots \ldots \ldots \ldots \ldots 1$. Ft. in.

Shale and clay............................... 110

Coal................................. $\quad 7 \frac{1}{2}$

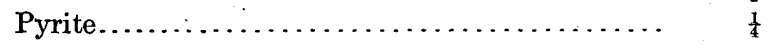

Coal................................ $\quad 11 \frac{1}{2}$

Shale.....................

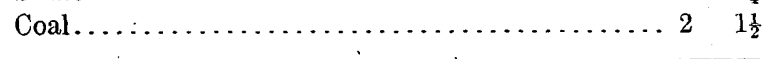

$6 \quad 7$

A proximate analysis of a sample from this mine shows moisture 4.5, volatile matter 35.3 ,

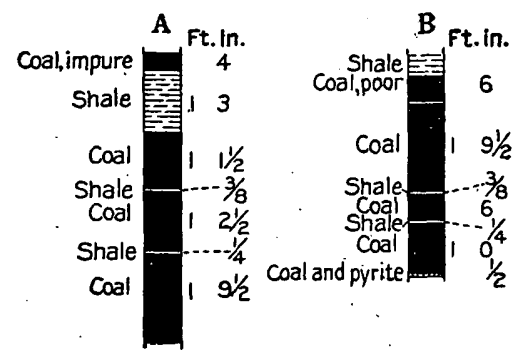

Figure 45.-Sections of Meigs Creek (No. 9) coal bed in Belmont County, Ohio. A, Flushing; B, Barnesville.

fixed carbon 47.1, and ash 13.1 per cent; an ultimate analysis shows carbon 65.83 , hydrogen 4.99, oxygen 11.71 , nitrogen 1.13 , sulphur 3.27 , and ash 13.07 per cent. Its heat value is 12,010 B. t. u.

The bed in this mine ranges from 3 feet 8 inches to 4 feet 3 inches in thickness and contains thin discontinuous partings of shale or pyrite. The coal has long been mined by farmers as the Upper Barnesville bed. Goshen Township, east of Warren Township, appears to be underlain by the Meigs Creek bed except in two small areas where streams have removed it. A measurement in the Statler mine, in the NE. $\frac{1}{4}$ sec. 36 , shows 4 feet of coal whose heat value is $11,840 \mathrm{~B}$. t. u. Union Township, north of Goshen, is almost wholly underlain by the Meigs Creek coal bed. In the Calbert mine, in the SE. $\frac{1}{4}$ sec. 25 , the bed is 4 feet 4 inches thick and has a heat value of $12,600 \mathrm{~B}$. t. u. In another mine in this township the section shown in figure 45, A, was measured. The coal is hard and bright but here and there contains streaks of shale or bony coal. The mine supplies the neighborhood farmers and also several mills at Belmont and Bethesda. Richland Township, east of Union, appears to be underlain by the Meigs Creek coal, except where the bed is cut out along McMahon and Wheeling creeks and their tributaries. The coal has been mined in a small way by several farmers. It shows well in the railroad cut at Glencoe, where it is about 85 feet above the Pittsburgh coal and measures approximately 4 feet in thickness. Another section is shown in figure 46, A. Smith Township, which lies south of Richland, is underlain by Meigs Creek coal except in a very small area in the extreme northeastern corner.

Section of Meigs Creek coal bed in Armstrong's mine, near Glencoe, Ohio.

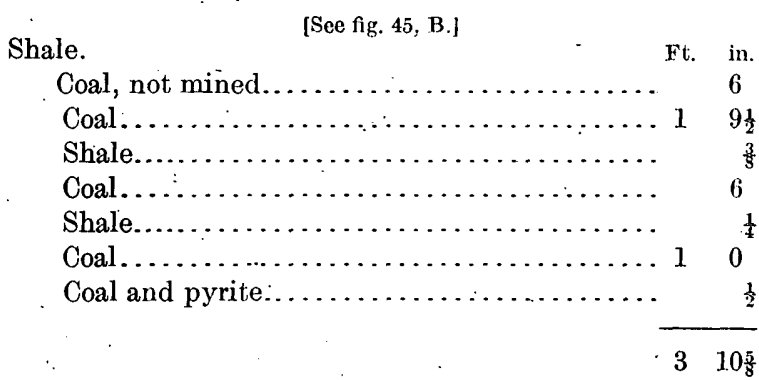

A proximate analysis of a sample from this mine shows moisture 3.5 , volatile matter 34.8 , fixed carbon 49.9 , and ash 11.8 per cent; an ultimate analysis shows carbon 67.36 , hydrogen 5.02 , oxygen 11.06 , nitrogen 1.05 , sulphur 3.67 ,

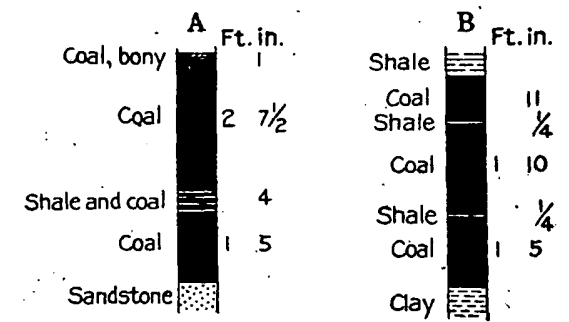

Figure 46.-Sections of Meigs Creek (No. 9) coal bed in Ohio. A, Richland Township, Belmont County; B, Athens Township, Harrison County.

and ash 11.84 per cent. The heat value is 12,390 B. t. u.

- The floor in this mine is uneven, and hence the thickness of the bed varies considerably. Thin, discontinuous partings of shale and pyrite are common. Pultney Township, which lies east of Richland, fronts on Ohio River and has been deeply trenched by MoMahon Creek and its leading tributaries. The local bed has been opened on several farms and in sec. 5 is reported to be 4 feet thick. Mead Township, south of Pultney, is underlain by the Meigs Creek coal bed except along Pipe and 
Wegee creeks, where the coal has been removed by erosion.

Section of Meigs Creek coal bed in Mc Millen mine, NW. $\frac{1}{4}$ sec. 32, Mead Township, Belmont County, Ohio.

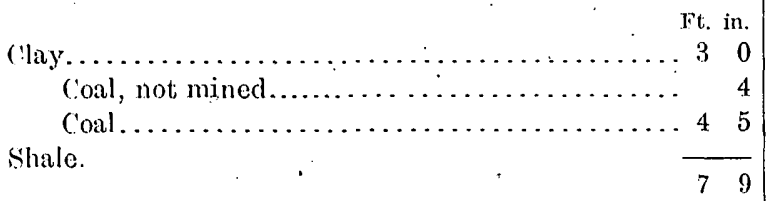

The southern tier of townships appears to contrin the Meigs Creek coal wherever due, but the bed is generally below drainage. In Somerset. Township the bed ranges from 2 feet 6 inches to 4 feet in thickmess and has been mined to a small extent by farmers. Along Captina Creek in Wayne, Washington, and York townships the coal is above drainage, except from the east part of Wayne to a point near the middle of Washington Township. The coal is said to have been mined in a disconnected way in the vicinity of Armstrongs Mills for more than 60 years and to range in thickness from 2 to $4 \frac{1}{2}$ feet. About $1 \frac{1}{2}$ miles south of the Belmont County line the coal is said to lie in the bed of Ohio River and to have been mined by stripping during low water.

From the preceding paragraphs it is apparent that the Meigs Creek bed contains a large tonnage of coal in Belmont County. Thus far it has been worked only in a small way, because those who were prepared to operate on a commercial scale have much preferred the thicker and better Pittsburgh bed, which lies only a short distance below.

The Meigs Creek bed, however, may be regarded as a fuel reserve which will be eagerly developed when the Pittsburgh bed is a thing of the past. The coal is of fair quality. Its sulphur content rarely equals 4 per cent and in one analysis made by the Ohio Geological Survey it is less than 2 per cent. The ash is high, reaching in some samples as much as 15 per cent and in few is as low as 10 per cent. The heat value usually ranges between 11,700 and 12,600 B. t. $u$. The average of seven analyses of samples taken in different parts of the county shows ash 12.2 , sulphur 2.99 , and moisture 4.6 per cent; the heat value is 12,140 B. t. u. and the moisture in air-dried samples is about 3 per cent.

Harrison County.-The Meigs Creek coal bed is present in only three townships in the south- east part of Harrison County-Short Creek, Athens, and Cadiz. In Cadiz Township it occurs in so small an area that it may be neglected. In Athens Township the acreage is large and the coal has been made accessible by numerous streams which cut through it.

Section of Meigs Creek coal bed in Joshua Kirk mine, 1 mile west of New Athens, Ohio.

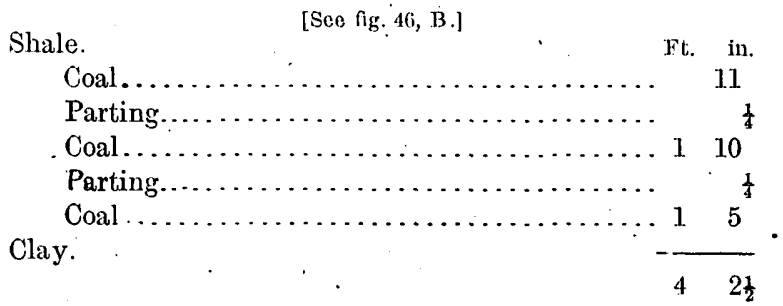

A proximate analysis of a sample from this mine shows moisture 5.3, volatile matter 33.1, fixed carbon 51.3, and ash 10.3 per cent; an ultimate analysis gives carbon 68.67 , hydrogen 5.21 , oxygen 12.38 , nitrogen 1.25 , sulphur 2.20 , and ash 10.29 per cent. The heat value is 12,340 B. t. u.

Section of Meigs Creek coal bed in Culberson mine, south of New Athens, Ohio.

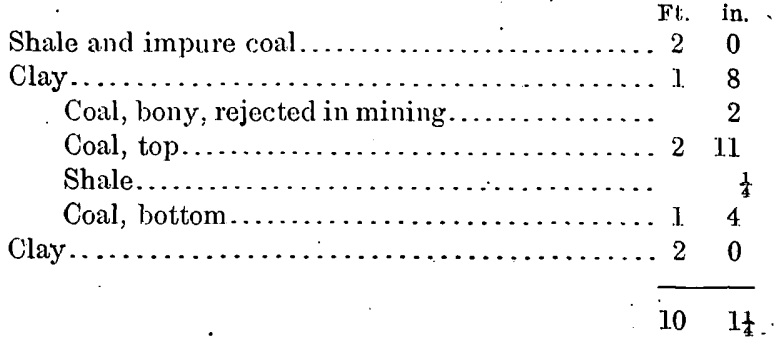

An average thickness of 4 feet 6 inches is claimed for the coal bed in this mine. Nodules of pyrite are common and are sorted out by the miners. This coal has been mined on many farms for local use.

The Meigs Creek coal bed underlies practically all of the southern half of Short Creek Township and, as the Pittsburgh coal is below drainage, is an important source of fuel for the farmers.

Section of Meigs Creek coal bed on Lodge farm, in sec. 16, Short Creek Township, Harrison County, Ohio.

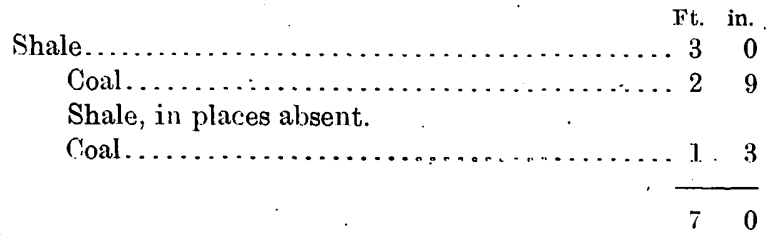


Noble County.-The Meigs Creek coal is found in Noble County in every township except Buffalo. East of Duck Creek, which crosses the coal field from north to south, the bed has been largely removed by tributaries to that stream and the coal underlies only the ridges. West of Duck Creek the coal underlies broader areas. It was formerly. worked for shipment on the narrow-gage road, a few miles west of Summerfield, and it has been opened at many places by farmers in every township where the coal is present. As the county is not well supplied with shipping facilities, the local supply of coal is at present - not valuable. In due time it will doubtless be extensively mined for shipment.

As stated, the Meigs Creek coal east of Duck Creek is limited to the divides between streams. In Marion Township the hills rise well above the coal, but the bed is uncertain and in places is not of workable thickness.

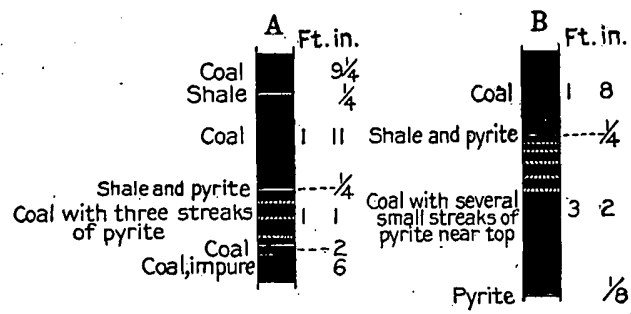

Figure 47.-Sections of Meigs Creek (No. 9) coal bed in Noble County, Ohio. A, Marion Township; B, Elk Township.

Section of Meigs Creek coal bed in mine on Hague farm, SW. $\frac{1}{4}$ sec. 12, Marion Township, Noble County, Ohio.

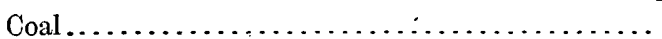
[See fig. $4 \bar{i}$, A.]
$\ldots \ldots \ldots \ldots \ldots \ldots \ldots \ldots \ldots$

Shale.....................................

Coal................................ 111

Shale and pyrite........................

Coal, with three pyrite streaks................ 1

Coal ................................. 2

Coal, impure, not mined................... 6

A proximate analysis of a sample from this mine shows moisture 3.1 , volatile matter 37.4 , fixed carbon 46.7 , and ash 12.8 per cent; an ultimate analysis gives carbon 65.61 , hydrogen 5.09 , oxygen 9.93 , nitrogen 0.92 , sulphur 5.60 , and ash 12.85 per cent. The heat value is 12,130 B. t. u.

Stock Township, south of Marion, has considerable coal, though extensively trenched by a branch of . Duck Creek. The thickness of the bed may average 4 feet with a maximum of 5 feet, but it usually includes several discontinuous shale or pyrite layers. One test of the coal gave 12,510 B. t. u. Elk Township, south of Stock, is an important mining center for an area without a railroad. The mines are in the northeast corner of the township, near the village of Stafford, and the coal is hauled long distances by the farmers.

Section of Meigs Creek coal bed in mine on G. W. Love farm on Shaler Run in Elk Township, Noble County, Ohio.

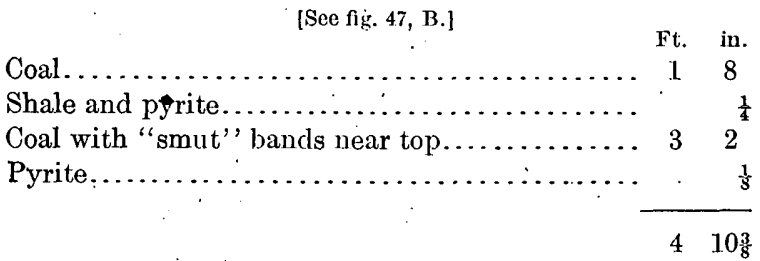

A proximate analysis of a sample from this mine shows moisture 3.1 , volatile matter 38.4 , fixed carbon 46.2 , and ash 12.3 per cent; an ultimate analysis shows carbon 66.18 , hydrogen 5.11, oxygen 9.52 , nitrogen 0.86 , sulphur 6.00 , and ash 12.33 per cent. The heat value is $12,360 \mathrm{~B}$. t. $\mathrm{u}$.

The roof of the coal in this township varies much, and in places numerous "rolls" or "horses" of clay with nodules of pyrite partly or entirely cut out the coal. Most of these breaks are 10 to 12 inches wide and have steep or vertical walls, as if the material had been deposited in canyon-like trenches cut in the coal. .

Jefferson Township, which lies west of Elk consists of high, narrow ridges separated by deep valleys. The area of the coal is not large, though adequate for local needs. Enoch Township, north of Jefferson, has a small area of coal near the tops of the ridges. A sample from the southwest corner of the township has a heat value of $12,690 \mathrm{~B}$. t. u. The remaining townships east of Duck Creek contain at the most small areas of this coal bed.

West of Duck Creek the Meigs Creek coal bed has suffered less stream erosion and therefore is not.confined to ridges and hills. Brookfield Township, which forms the northwest corner of the county, contains a large area of the coal, which has long been mined for local use among the farmers in the village of Cumberland. 
Section of Meigs Creek coal bed in mine on Hunter farm, NW. $\$$ sec. \&, Brook:feld Township, Noble County, Ohio.

Ft. In.

Coal, bony $\ldots \ldots \ldots \ldots \ldots \ldots \ldots \ldots \ldots \ldots \ldots$

Shale.

Coal ..............................

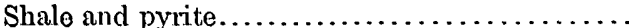

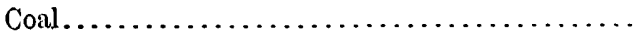

Shale and coal

Coạl with two "smut" bands................

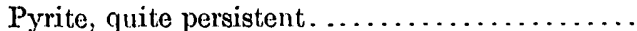

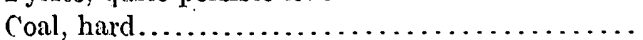

Coal in floor, not mined.

A proximate analysis of a sample from this mine shows moisture 4.8 , volatile matter 37.3 , fixed carbon 48.1, and ash 9.8 per cent; an ultimate analysis gives carbon 66.01 , hydrogen 5.26 , oxygen 12.35 , nitrogen 0.97 , sulphur 5.59 , and ash 9.82 per cent. The heat value is 12,300 B. t. u.

The coal bed in this mine ranges from 4 feet 4 inches to 5 feet in thickness, but its upper $5 \frac{1}{2}$ inches consists of bony coal and is generally rejected. Also from 4 to 8 inches of good coal is left in the floor of the mine, owing to the quantity of water that the bed contains. In Sharon Township, which lies south of Brookfield, the coal bed generally is 3 to $3 \frac{1}{2}$ feet in thickness in the northern part of the township and 4 to $4 \frac{1}{2}$, feet in the southern part. In places the roof is weak and requires careful timbering. Thin shale partings, balls, and lenses of pyrite are common. Jackson Township forms the. southwestern corner of the county and probably has as large an area of this coal bed as any other two townships in the county combined. The coal has been mined by farmers at many places, especially in the northwest part of the township; and from these mines the fuel is hauled for miles in all directions. In many places the bed is divided in to two benches by a bed of clay, which may have a thickness of 18 inches. In places in sec. 10 the coal bed is 6 feet thick, but in sec. 19 a bed of sandstone reduces it to 4 feet.

The average of six analyses from samples taken in various parts of the county shows ash 11.6, sulphur 5.58, and moisture 3.3 per cent. The heat value is $12,320 \mathrm{~B}$. t. u.

These results show an increase in sulphur to nearly twice that in Belmont County, a decrease in moisture, and a slight increase in heat value.
Morgan County.-The Meigs Creek coal bed extends west from Noble County into Morgan, where it is of workable thickness nearly everywhere east of Muskingum River but is worthless and in places absent west of that stream. Just east of the river the ooal is limited to ridges and hilltops, but nearer the Noble County line it lies lower and hence has been less removed by stream action. The field is drained by Meigs Creek, from which stream the coal received its name.

Manchester Township, forming the northeast corner of the county, contains a large area of the coal, which has long been mined near

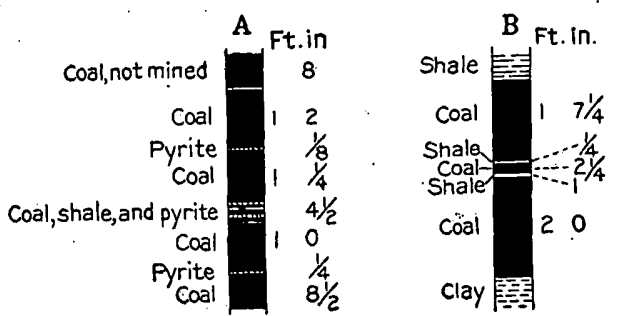

Figure 48.-Sections of Meigs Creek (No. 9) coal bed in Morgan County, Ohio. A, Manchester Township; B, Bristol Township.

Reinersville and is hauled thence by farmers many miles.

Section of Meigs Creek coal bed in L. H. Grandstaff mine, in the SW. $\frac{1}{4}$ sec. 29, Manchester Township, Morgan County, Ohio.

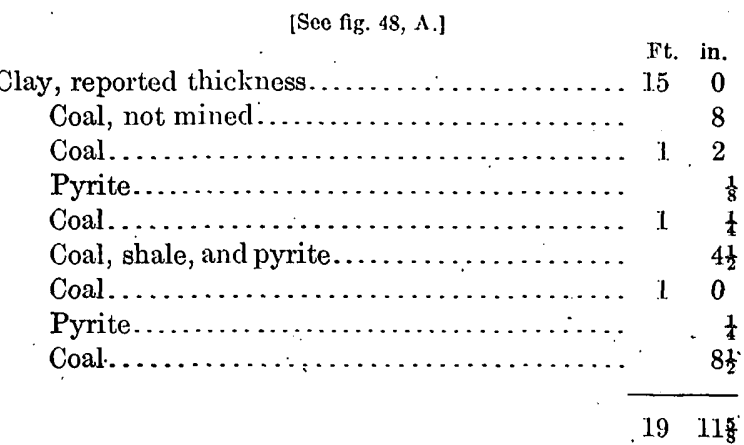

A proximate analysis of a sample from this mine shows moisture 4.1 , volatile matter 37.6 , fixed carbon 47.6 , and ash 10.7 per cent; an ultimate analysis shows carbon $66: 19$, hydrogen 5.10 , oxygen 12.11 , nitrogen 0.87 , sulphur 5.07, and ash 10.66 per cent. The heat value is $12,200 \mathrm{~B}$. t. u.

In addition to such impurities as are shown in the section given above numerous paper-like layers of shale traverse the bed. The coal is bright and when iridescent is called peacock 
coal. Bristol Township, which lies west of Manchester Township, has thousands' of acres of Meigs Creek coal beneath its hills and ridges. One test shows 4.3 per cent sulphur and 12,110 B. t. $u$. The thickness of the ooal bed, where tested (see fig. 48, B), is 3 feet $9 \frac{1}{2}$ inches, exclusive of partings. A measurement made on the A. E. Smith farm in sec. 25 shows 5 feet 4 inches of coal in three benches, of which the thiickest (10 inches) was not mined. Meigsville -Township lies south of Bristol and contains a large area of the Meigs Creek coal.

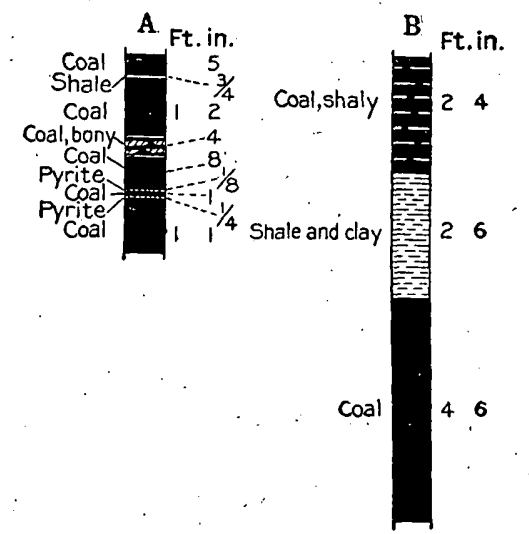

F'IGURE 49.-Sections of Meigs Creek (No. 9)-coal bed in Ohio. A Meigsville Township, Morgan County; B, Aurelius Township, Washington County.

Section of Meigs Creek coal bed in F. S. Murray mine, sec. 20, Meigsville. Township, Morgan County, Ohio.

Clay.

[See fig. 49, A.] .

Coal, usually about 5 inches thick..........

Shale................................

Coal,."smut"'streak near middle...........

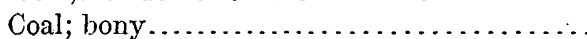

Coal...............................

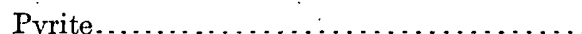

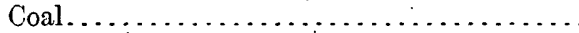

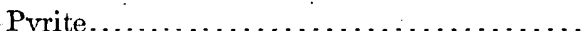

Coal. .

12

A proximate analysis of a sample from this mine shows moisture 5.1, volatile matter 36.1; fixed carbon 47.1, and ash 11.7 per cent; an ultimate analysis gives carbon 64.77 , hydrogen 5.06 , oxygen 12.67 , nitrogen 0.87 , sulphur 4.89, and ash 11.74 per cent. The heat value is 11,930 B. t. u.

Center Township forms the southeast corner of the county and contains a larger area of
Meigs Creek coal than any other township in the county. The bed usually ranges from 2 feet 6 inches to 4 feet 4 inches in thiokness and is divided into two benches, separated by 1 to 6 inches of shale or impure coal. Both floor and roof are irregular, and the thickness of the bed changes abruptly. Windsor Township, north of Muskingutm River, appears to be underlain by a solid block of coal 3 feet to 3 feet 6 inches thick. An average of three analyses from samples taken in different townships shows ash 10.9 , sulphur 4.75 , and moisture 4.8 per oent. The heat value is $12,080 \mathrm{~B}$. t. $\mathrm{u}$.

Washington County.-In Washington County the Meigs Creek coal bed is present, under a large area between .Muskingum and Little Muskingum rivers and north of Cow Run. It is believed to be of workable thickness throughout nearly this area and at three places outside of it-in the valley of Cow Run; a short distance west of Newport, where the Burning Springs anticline brings it far above drainage; and in the extreme southeast corner of the county. The areas of coal in these three places, however, are small and can never be of more than local value.

The Meigs Creek coal bed has been given several names in Washington County, and some people are still confused as to its position. Both the coal bed and the Ames limestone are well shown along the valley of Duck Creek, a short distance north of the Washington County line, and the coal can be followed down this valley to the point where it passes below drainage at the mouth of Cow Run. The position of the coal with reference to the Ames limestone proves it to be the Meigs Creek bed beyond a reasonable doubt. The coal bed is thickest and most persistent in the townships along the northern border of the county and is there a valuable bed which will, some day, be the basis of important mining operations, though at present it is worked for local market only.

Aurelius, the northernmost township in the county, contains a large acreage of Meigs Creek coal, though much has been swept away by Duck Creek. Formerly the fuel was mined for shipment by rail at Macksburg, but the practice was discontinued many years ago. 
Section of Meigs Creek coal bed on Charles Schimmel's land, sec. 28, Aurelius Township, Washington County, Ohio.

Coal, lower part only of upper bench Ft. in.

Shale and clay $\ldots \ldots \ldots \ldots \ldots \ldots$

Coal.................................... 8

Shale..................................

Coal............................. $3 \frac{2}{4}$

A proximate analysis of a sample from this mine shows moisture 3.4, volatile matter 37.9 , fixed carbon 49.1, and ash 9.6 per cent; an ultimate analysis gives carbon 68.33, hydrogen 5.31, oxygen 10.85 , nitrogen 0.90 , sulphur 5.03, and ash 9.58 per cent. The heat value is $12,750 \mathrm{~B}$. t. u.

Section of Meigs Creek coal bed on A. F. Wooster's land, in valley of Duck Creek, Aurelius Township, Washington County, Ohio

Ft. in.

Coal................................ 2

Shale.................................... 1 3

Coal............................. 10

$\overline{67}$

Another section of the Meigs Creek coal bed in Aurelius Township is shown in figure 49, B.

Salem Township, which lies south of Aurelius, is crossed by the deep valley of Duck Creek. The coal appears to be present in this township wherever it is due and to be of good thickness. It has been worked on many farms and is the local source of fuel among the residents. Along Bear Creek, in the southwest part of the township, the coal bed measures 4 to 5 feet and is almost free from partings. East of Duck Creek, in this township, the bed is thick and is divided into two benches by a thick bench of shale or clay.

Section on T'wiggs farm on Pawpaw Creek, Salem Township,

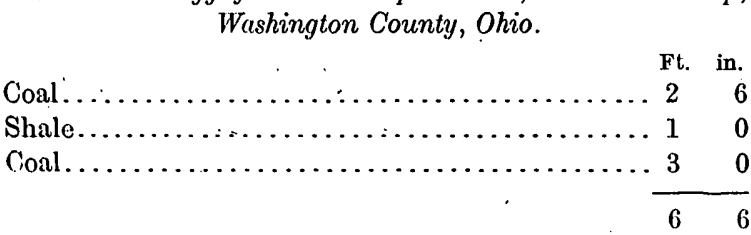

The coal is thinner in the southern part of the township, where it measures about 4 feet; over the line in Fearing Township it is still thinner and is probably worthless.

The Meigs Creek coal is well developed in the parts of Waterford and Adams townships east of Muskingum River, where it usually ranges from 2 to 4 feet in thickness and is divided into two parts by a thick bed of shale or clay. The best known mine is at Coal Run, on Muskingum River. It has been worked discontinuously for 25 years and supplies many farmers and occasionally ships a barge load to Marietta.

Section of Meigs Creek coal bed in the Felix mine at Coal Run, Washington County, Ohio.

Clay.

Coal. .................

"Smut" streak........................

Coal................................. 4

Coal, pyrite and shale................. 3.3

Coal, with two pyrite streaks.............. 11 .

Coal, forming floors in entries.............. 4

$35 \frac{7}{8}$

A proximate analysis of a sample from this mine shows moisture 2.9 , volatile matter 37.5 , fixed carbon $46.7,-$ and ash 12.9 per cent; an ultimate analysis gives carbon 65.88 , hydrogen 5.05 , oxygen 9.71 , nitrogen 0.92 , sulphur 5.55 , and ash 12.89 per cent. The heat value is $12,250 \mathrm{~B}$. t. $\mathrm{u}$.

In Liberty Township and the northwest part of Ludlow the coal bed has a good thickness and is well exposed along Campbells Run and Pawpaw Creek. The following measurement was made in a cut at Germantown:

Section of Meigs Creek coal bed at Germantown, Ohio.

Ft. in. Coal....................................

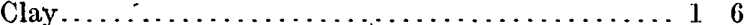

Coal.......................... 3

The lower bench appears to be the better in quality, though both are mined.

Section on McCurdy farm, in the NW. 1 sec. 34, Ludlow Township, Washington County, Ohio.

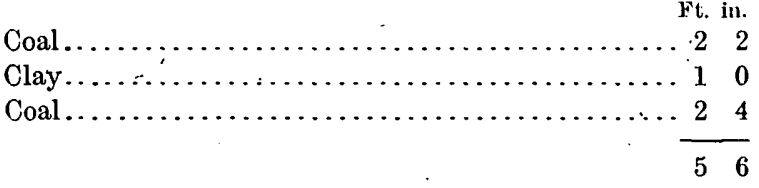

The coal bed thins abruptly to the north in Ludlow Township, and on the Payne farm in sec. 16 it measures only 8 inches: The quantity of coal in Liberty, and Ludlow townships is large and as yet has scarcely been touched by the miner. Like the rest of the Meigs Creek coal in Ohio it forms a large fuel reserve for future generations. 
Monroe County.-The area of the Meigs Creek coal bed above drainage in Monroe County is small and is confined to a narrow strip that borders Noble County and that may be considered as an extension of the Noble County field and to a small area near the hamlet of Mechanicsburg, in the southeast corner of Perry Township. Probably not more than two sections in Seneca Township have the coal in workable thickness, but Franklin and Bethel townships have larger areas and in them coal is mined on several farms. The coal bed is thickest along the Noble County line, where it measures about 4 feet. Eastward it thins abruptly and beyond the middle of the townships is of minable thickness in few if any places. The coal bed consists of two benches, separated by shale, 6 to 18 inches thick.

Probably the Meigs Creek coal of Belmont County extends south into northern Monroe County but is below drainage, and specific data as to its thickness and quality are lacking.

Muskingum and Guernsey counties.-The Meigs Creek coal underlies the high hills and ridges in the southeast corner of Muskingum County and to a much smaller extent in the adjacent part of Guernsey County. Meigs and Rich Hill contain more of this coal bed than do any other townships in Muskingum County; the bed generally measures 3 to 4 feet in thickness and contains two or more shale partings.

\section{UNIONTOWN AND WAYNESBURG COAL BEDS.}

Near the village of Harrisville, in the extreme southeast corner of Harrison County, the Uniontown coal is found in the highest hills, about 100 feet above the Meigs Creek bed, and was formerly mined on a very small scale. In northern Belmont County it is also found 100 to 110 feet above the Meigs Creek coal. The bed is about 2 feet thick at Flushing but thickens a little to the east, and in Colerain Township measures 3 to 4 feet. The position of this coal bed with reference to those below is shown in the section below:

\section{Section at Barton, Ohio. [By J. E. Hyde.]}

Shale with a few thin layers of sandstone....... Coal, Uniontown........................ 3

Unseen............................... 45

Sandstone, thin bedded.................. 13

Limestone.............................. 10

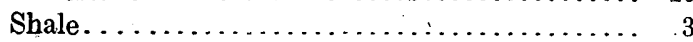

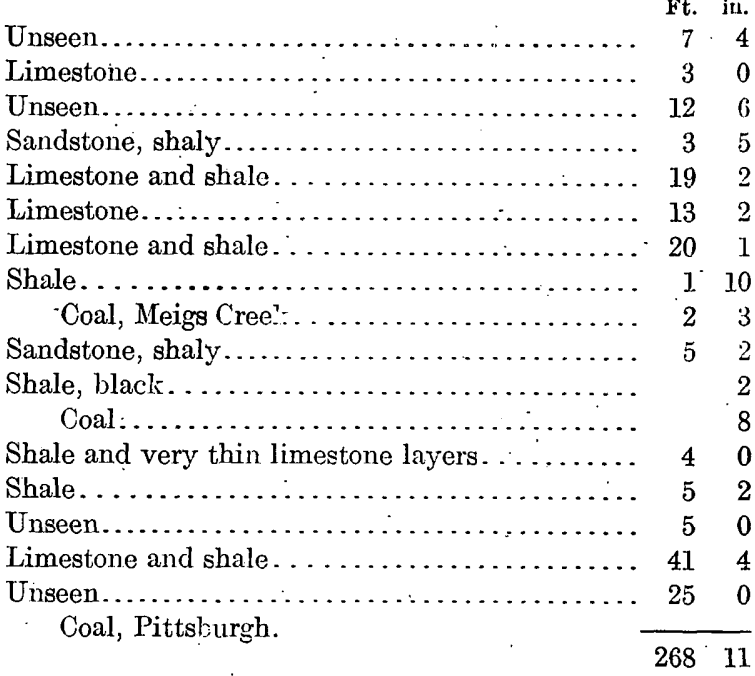

The Uniontown coal, according to Hyde, ranges from 110 to 145 feet above the Meigs Creek coal in this part of Belmont County. It is known locally as the "Three-foot seam" and has been mined in a very small way at several places in Colerain Township. About 100 feet above the Uniontown coal in this part of Belmont County is another coal bed in the hilltops which is known among the farmers as the "Upper Six-foot bed" and also as the "Cut seam," from its exposure in the cut on the Colerain pike at the top of the hill back of Martins Ferry. This coal, which has been worked at Colerain; is of poor quality and belongs in the Dunkard group. In Pease Township, which lies east of Colerain, the Uniontown or "Three-foot" coal has been worked at a number of places, especially in secs. 35 and 36 . In that locality a coal bed 2 feet 6 inches in thickness was noted lying from 25 to 40 feet below the Uniontown coal.

The Uniontown coal has been mined by farmers at many other places in Belmont County. Near St. Clairsville the coal has been mined on a number of farms, but the bed is thin and the output very small. In the vicinity of Belmont, Goshen Township, in the southeast corner of Union Township, and along the southward-flowing tributaries of Captina Creek this coal has been worked in numerous places. To sum up, the Uniontown coal occupies large areas in the hills of Belmont County, but the bed is thin and the coal of rather poor quality. Although it has been mined on many farms the quantity removed is insignificant, and it may be regarded as a fuel reserve which will 
be eagerly sought when the underlying Pittsburgh and Meigs Creek coals have been exhausted. Two or three western States are now mining coals for railroad shipment that are not thicker and apparently are not superior in quality to the Uniontown. This coal is mined by farmers along Sunfish Creek and probably at several other places in Monroe County.

The Waynesburg coal, which forms the summit of the Monongahela formation, is of very little value as a source of fuel. Its thickness varies and it is only in small areas that it is workable. The coal is at its best in the southern part of Belmont County, where it ranges in thickness from 2 to 4 feet. Condit reports that it is mined in the vicinity of Alledonia station, at Somerton, and along Bend Fork east of Hunter. It was formerly mined on the Yocum farm near Somerton, Somerset Township, for use in a mill, but the mine was abandoned because of trouble with water. The coal is reported to be less than 3 feet thick and of poor quality. It thins to the south and in the adjacent part of Monroe County is reported worthless.

\section{COAL BEDS OF THE DUNKARD GROUP.}

The Dunkard group, formerly known as the "Upper Barren Coal Measures," is the youngest formation in Ohio and is found only in the high hills and ridges in the eastern and southern parts of the State. The group includes two formations, the Greene above and the Washington below. Orton assigned to it a thickness of 500 feet, but recent work by Stauffer increases this to 636 feet. The formation rests on the Waynesburg coal, the top member of the Monongahela formation, and extends from that bed to the tops of the highest hills and ridges.

The following section, measured by C. R. Stauffer, shows the composition of the group as exposed near Jacobsburg, Belmont County:

Section of Dunkard group and upper part of the Monongahela formation in Belmont County, Ohio.

Dunkard group:

Shale, gray, to top of hill back of barn on Ft. in. A. R. Kelsey's farm................ 128

Sandstone, rather massive, micaceous, gray,

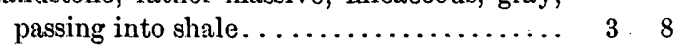

Shale, gray..................... $17 \quad 2$

Shale, black to bluish, resembling a coal blossom; contains plant fragments. .........

Limestone, clayey, gray; weathers rapidly...

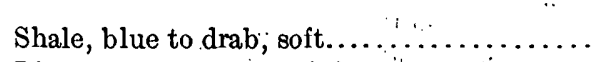

Limestone, gray, containing ostracodes....

Shale, gray, with some limestone nodules....

Limestone, nodular, gray................

Shale, soft, gray, with numerous calcareous

nodules. . . . . ...................

Sandstone, thin bedded, gray. . . . . . . . .

Shale, soft, fissile, gray.................

Limestone, drab, in thin layers, with calcareous shale between; fossiliferous; Upper Washington limestone member............

Shale, soft, clayey, red and gray...........

Concealed (aneroid reading) . . . . . . . . . . .

Sandstone, gray . ......................

Concealed (aneroid reading) . . . . . . . . . .

Sandstone, thin, cross-bedded..............

Shale, soft; gray.....................

Limestone, compact drab and clayey gray shale; lower layer nodular; fossiliferous; Middle Washington limestone member.....

Shale, gray and red, with several thin coal blossoms and nodules of sandstone........ $25 \quad 4$ Coal, Washington................. 4 .. 6

Shale, greenish gray to buff, with a few concretionary nodules................... $17 \quad 6$

Sandstone, micaceous, gray............. $\quad .5 \quad 10$

Shale, micaceous, sandy, gray ............ $\quad 5 \quad 10$

Sandstone, gray to yellowish, micaceous, laminated.................... 13

Shale, gray to buff, containing some small

iron nodules...................... $19 \quad 0$

Sandstone, micaceous, gray ............ 15

Shale, sandy, gray to buff, micaceous.............. $12 \quad 2$

Sandstone, gray, laminated, micaceous...... 20.9

Shale, fissile, gray..................... $\quad 9 \quad 10$

Sandstone, micaceous, gray.............. $1 \quad 10$

. Shale, gray to buff, sandy. . . . . . . . . . $\quad 8 \quad 10$

Limestone, blue, shaly, containing ostracodes; Elm Grove limestone member..... $14 \quad 4$

Shale, gray $\ldots \ldots \ldots \ldots \ldots \ldots \ldots \ldots \ldots \ldots, 2,0$ Monongahela formation:

Coal, Waynesburg, upper bench........ $1 . \quad 0$

Shale, gray to drab, sandy, micaceous. ..... $2 \quad 2 \quad 9$

Sandstone, gray, cross-bedded and in places shaly, micaceous; contact with coal below irregular. ...................... Coal, Waynesburg, lower bench......... Level of Ohio River \& Western Railway at School No. 12.

Concerning the rocks of the Dunkard, Stauffer writes:

A large part of the Dunkard in Ohio is to be classed as: red beds, although the Monongahela formation and even the Conemaugh are not without their red shales, which in. the Monongahela are often so like those of the Dunkard as to make them easily confused if it were not for other rather easily identified strata associated therewith. There are 210 but few really red sandstones and those usually only $3 \quad 1$ coated red on the outside or weathered surface in the Junk- 
ard formation of Ohio. The red is thus almost confined to the shale. In the northern part of the Dunkard area the red beds are to be found chiefly in the upper part of the formation, but to the southward most of the shale in the whole formation is red. In the main these shales, sandstones, limestones, and beds of coal represent land, swamp, and fresh-water deposits, but the presence of gypsum in certain of the shales and sandstones and again marine or brackish-water fossils in other beds indicates that these conditions at times gave place to others of a very different character.

From the economic standpoint the shales and sandstones occupy the place of most importance both now and for the future. The shales are being utilized, at Marietta, in the manufacture of brick, while in the same general locality three or four of the sandstones are extensively used in the manufacture of grindstones.

The coals of the Dunkard have little or no value in Ohio. The principal beds are the Waynesburg "A," Washington, Washington "A,". Jollytown, Dunkard, and Nineveh, but these are in many places represented by streaks only, and not one of them is regularly mined in Ohio. Near Alledonia, Belmont County, the Waynesburg " $A$ " coal is 18 inches thick and has been worked in a few places by farmers. The Washington is the best developed and most persistent coal bed in the Dunkard. It measured over 7 feet in the deep cut on the Colerain pike above Martins Ferry but is impure and can not be marketed under existing conditions. This coal is found elsewhere in Belmont County and in places in Monroe and Washington counties. Farmers have tested it at many places but have always been disappointed.

\section{COMPOSITION OF OHIO COALS.}

The following tables showing the composition of Ohio coals were compiled from Bulletin 9 of the Ohio Geological Survey and from recent publications of the United States Geological Survey and Bureau of Mines.

The samples were cut under the same general conditions, which are those prescribed by the United States Geological Survey. It is believed, therefore, that comparisons can safely be made and that the figures are a fair representation of the composition of Ohio coals.

In the "Reference" column "Ohio" refers to the Geological Survey of Ohio, "Mines" to the United States Bureau of Mines, and "U.S.G. S." to the United States Geological Survey.

Aralyses of Ohio coals.

[Made by Ohio Gcological Survey, U.S. Bureau of Mrines, and the United States Geological Survey.]

Sharon coal (No. 1).

\begin{tabular}{|c|c|c|c|c|c|c|c|c|c|c|c|c|c|c|}
\hline \multirow[b]{2}{*}{ County. } & \multirow{2}{*}{ Township. } & \multirow{2}{*}{$\begin{array}{c}\text { Mine or } \\
\text { labora- } \\
\text { tory } \\
\text { number. }\end{array}$} & \multicolumn{3}{|c|}{ Proximate. } & \multicolumn{6}{|c|}{ Ultimate. } & \multirow{2}{*}{$\mid \begin{array}{c}\text { British } \\
\text { thermal } \\
\text { units.1 }\end{array}$} & \multicolumn{2}{|c|}{ Reference. } \\
\hline & & & $\begin{array}{l}\text { Mois- } \\
\text { tute. }\end{array}$ & $\begin{array}{l}\text { Volatile } \\
\text { matter. }\end{array}$ & $\begin{array}{c}\text { Fixed } \\
\text { car- } \\
\text { bon. }\end{array}$ & Ash. & $\begin{array}{l}\text { Sul- } \\
\text { phur. }\end{array}$ & $\begin{array}{l}\text { Hy: } \\
\text { dro- } \\
\text { gen. }\end{array}$ & $\begin{array}{l}\text { Car- } \\
\text { bon. }\end{array}$ & $\begin{array}{c}\text { Nitro- } \\
\text { gen. }\end{array}$ & $\begin{array}{l}\text { Oxy- } \\
\text { gen. }\end{array}$ & & $\begin{array}{l}\text { Organiza- } \\
\text { tion. }\end{array}$ & $\begin{array}{l}\text { Bull. } \\
\text { No. }\end{array}$ \\
\hline $\begin{array}{r}\text { Jackson....... } \\
\text { Do...... }\end{array}$ & 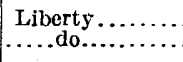 & $\begin{array}{l}15188 \\
15189\end{array}$ & $\begin{array}{l}13.6 \\
12.8\end{array}$ & $\begin{array}{l}31.8 \\
31.5\end{array}$ & $\begin{array}{l}50.4 \\
47.9\end{array}$ & $\begin{array}{l}4.2 \\
7.8\end{array}$ & $\begin{array}{r}0.86 \\
.97\end{array}$ & & & & & $\begin{array}{l}11,680 \\
11,270\end{array}$ & $\begin{array}{c}\text { Mines...... } \\
\ldots \text { do......... }\end{array}$ & $\ldots \ldots$ \\
\hline
\end{tabular}

Quakertown coal (No. 2).

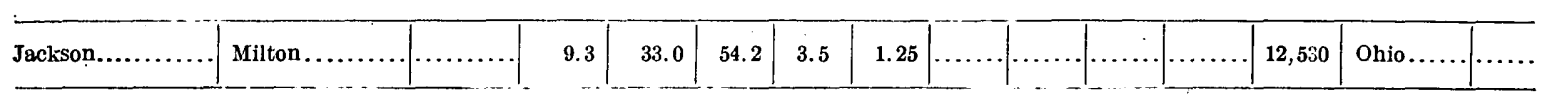

Clarion coal (No. 4a).

\begin{tabular}{|c|c|c|c|c|c|c|c|c|c|c|c|c|c|c|}
\hline Lawrence & Decatur. & 65 & 6.3 & 35.3 & 41.0 & 17.41 & 5.29 & 4.91 & 57.92 & 1.07 & 13.40 & 10,740 & Ohio.. & 9 \\
\hline Do. & ..... do... & 67 & 5.9 & 37.2 & 41.6 & 15.28 & 5.36 & 5. 06 & 60.22 & 1.18 & 12.90 & 11,130 & ..do. & 9 \\
\hline Do. & do. & 68 & 6.1 & 38.5 & 45.5 & 9.94 & $\begin{array}{l}3.61 \\
3.61\end{array}$ & 5.42 & 65.53 & 1.22 & 14.28 & 11,960 & do. & 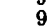 \\
\hline Do. & Washington & 66 & 6.0 & 39.1 & 43.0 & 11. 86 & 5.10 & 5. 26 & 63.32 & 1.22 & 13.24 & 11,730 & do & 9 \\
\hline cioto.: & Bloom.. & 64 & 6.8 & 37.9 & 46.0 & 9.34 & 3.45 & 5.33 & 65.30 & 1. 23 & 15.35 & 11,760 & do & 9 \\
\hline ackson. & Madison. & 63 & 4.9 & 35.7 & 45.7 & 13.70 & 6.14 & 4.89 & 62.57 & 1. 23 & 11.47 & 11,500 & do & 9 \\
\hline Do. & Bloomfiel & 62 & 5.3 & 37.4 & 43.8 & 13.54 & 6.08 & 4.98 & 62.05 & 1.23 & 12.12 & 11,380 & do & 9 \\
\hline Do & Milton. & 55 & 5.6 & 38.9 & 47.4 & 8.09 & 3. 70 & 5.47 & 67.30 & 1.28 & 14.16 & 12,280 & & 0 \\
\hline Do. & .....do... & 56 & 5.0 & 39.7 & 45.5 & 9.80 & 4.08 & 5. 39 & 66.14 & 1. 28 & 13.31 & 12,150 &.$d$ & 9 \\
\hline Do. & ....do.. & 57 & 4.7 & 40.5 & 46.2 & 8.61 & 3.73 & 5.44 & 67.51 & 1. 26 & 13.45 & 12,360 & . d & 9 \\
\hline Do & ..do.. & 60 & 5.3 & 41.0 & 45.3 & 8.40 & 3.72 & 5.50 & 66.52 & 1.28 & 14.58 & 12,210 & $\therefore \mathrm{d}$ & \\
\hline Do. & do. & 1896 & 8.4 & 41.3 & 43.6 & 6.7 & 3.10 & & & & & 12,250 & U. & 290 \\
\hline Do & do & 1897 & 7.5 & 39.3 & 42.7 & 10.5 & 5.44 & & & & & & do & \\
\hline Vinton. & Wilkesville & 59 & 4.7 & 39.9 & 44.2 & 11. 21 & 4.16 & 5.36 & 65.04 & 1. 28 & 12.95 & 12,050 & Ohi & 9 \\
\hline Do. & ....do. & 61 & 4.5 & 40.1 & 46.5 & 8.85 & 4.23 & 5.44 & 67.17 & 1. 28 & 13.03 & 12,340 & . do & \\
\hline DP & ....do... & 2208 & 6.8 & 40.0 & 45.5 & 7.7 & 3.34 & & & & & 12,510 & U.S.G.s. & \\
\hline Do & ....do... & 2209 & 7.4 & 41.6 & 44.8 & 6.2 & 2.77 & & & & & & ..do.... & 90 \\
\hline Do. & vinton.. & 54 & 5.0 & 40.3 & 46.5 & 8.21 & 2.81 & 5. 49 & 68.52 & 1. 28 & 13.69 & 12,470 & Ohi & 9 \\
\hline Do & do. & 58 & 4.6 & 41.4 & 42.9 & 11.10 & 5.28 & 5.36 & 64.91 & 1.30 & 12.05 & 12,050 & $\ldots \mathrm{d}$ & 9 \\
\hline Do & Madison... & 70 & 5.0 & 39.9 & 46.1 & 8.97 & 3.32 & 5.48 & 67.92 & 1.33 & 12.98 & 12,530 & $\cdots d$ & 9 \\
\hline & Elk... & 69 & 4.9 & 39.2 & 46.6 & 9.32 & 3.53 & 5.40 & 67.17 & 1. 30 & 13.28 & 12,450 & $\cdots$ do.. & 9 \\
\hline
\end{tabular}

1 British thermal units may be reduced to pound calories by multiplying by 0.5556 and to French calories by multiplying by 0.252 . 
THE COAL FIELDS OF OHIO.

Analyses of Ohio coals-Continued.

Lower Kittanning coal (No. 5).

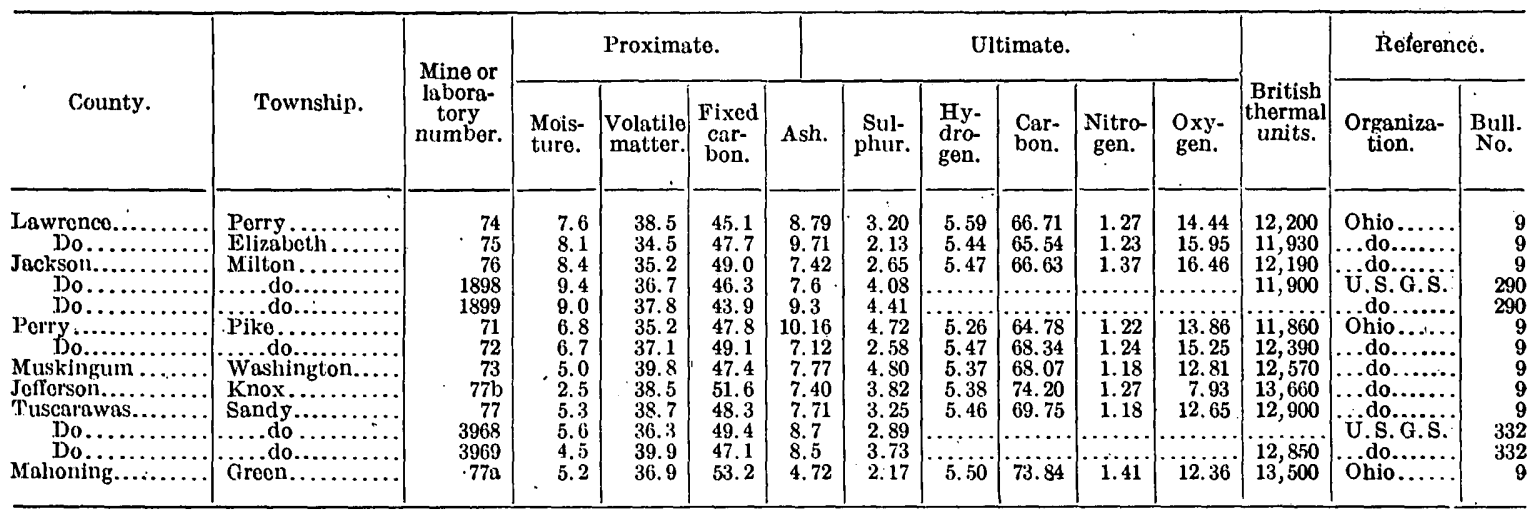

Middle Kittanning coal (No. 6).

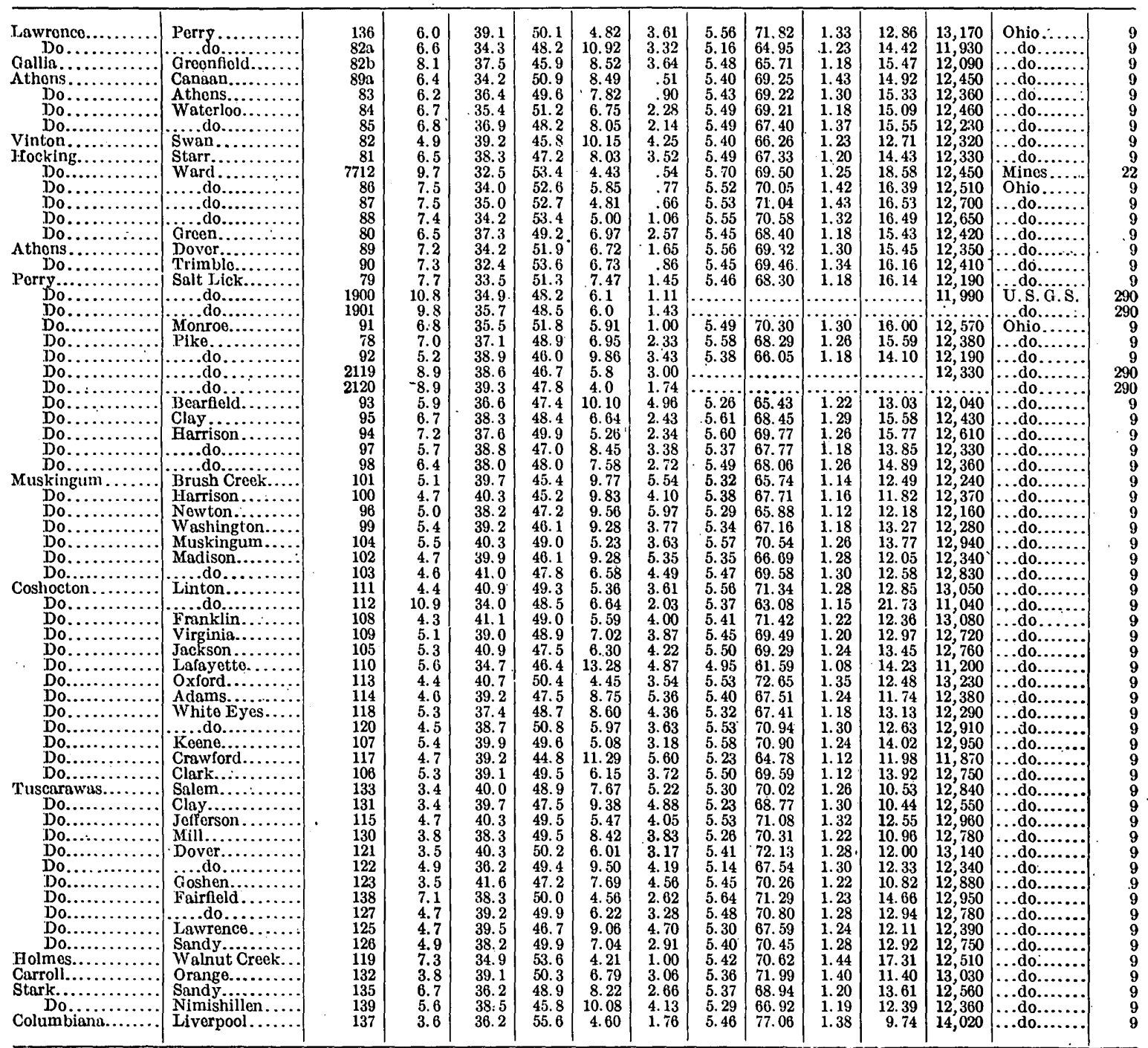


Analyses of Ohio coals-Continued.

Lower Freeport coal (No. 6a).

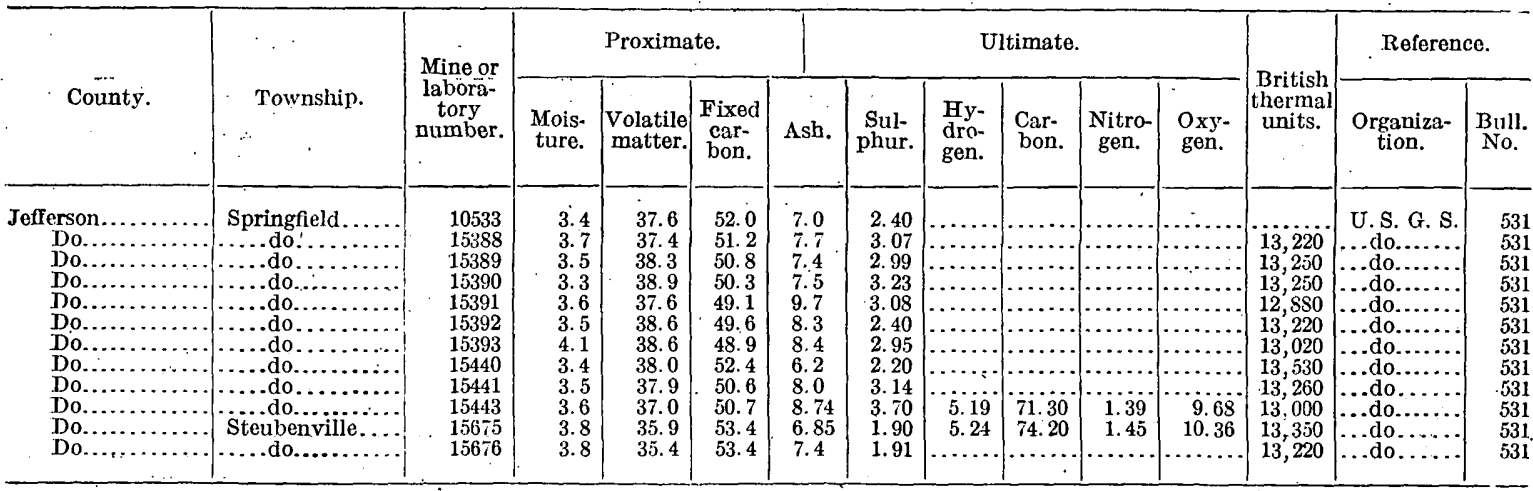

Upper Freeport coal (No. 7).

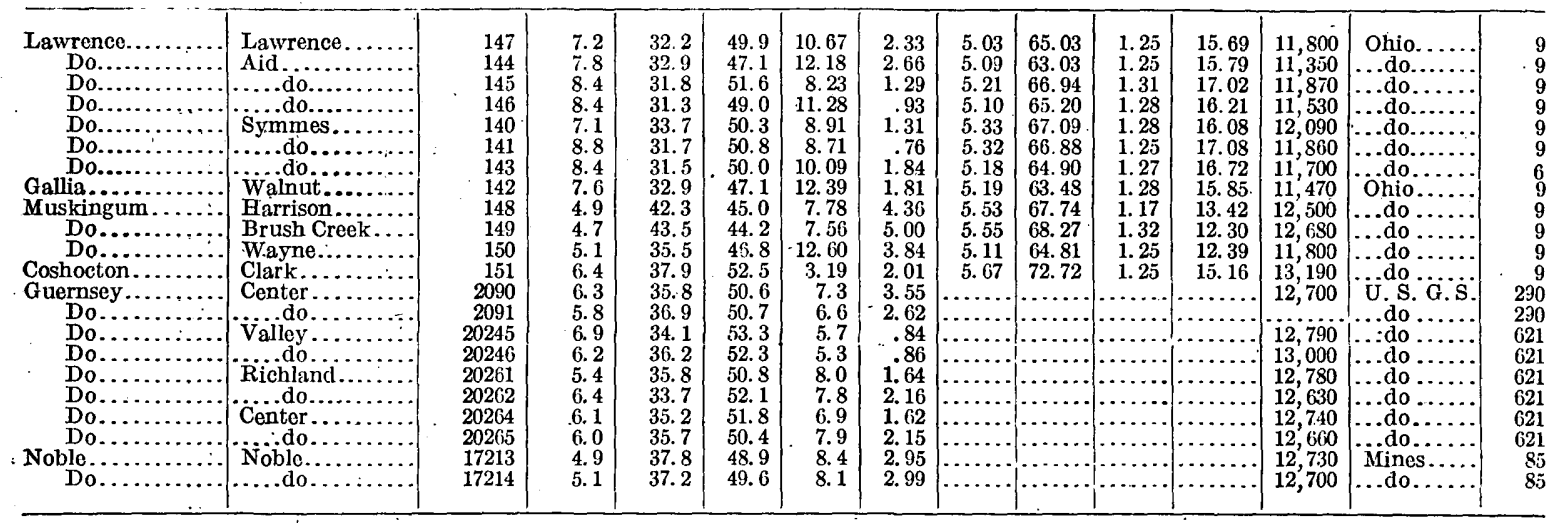

Pittsburgh coal (No. 8).

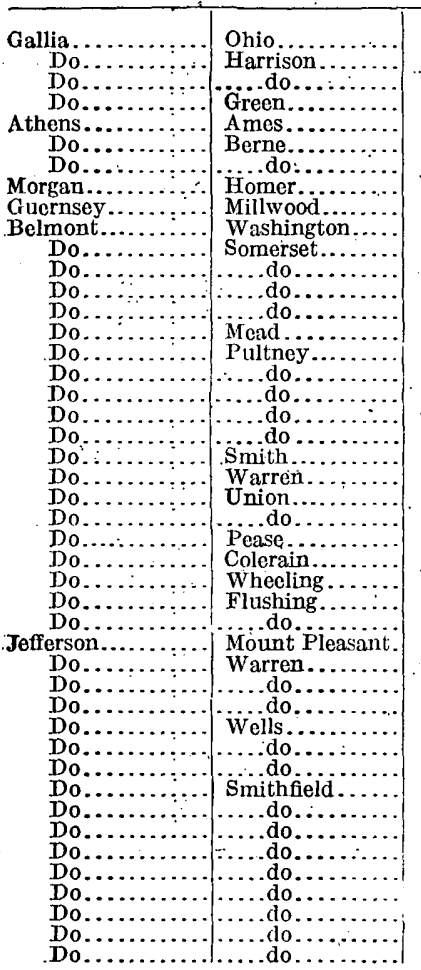

\begin{tabular}{|c|c|c|c|c|c|c|c|c|c|c|c|c|}
\hline 25 & .8 & 36.7 & 47.4 & 10.06 & 4.34 & 5.16 & 64.94 & 1. 10 & 14.40 & 11,790 & Ohio & \\
\hline 27 . & 7 & & 47.9 & 9.03 & 5. 21 & 5. 24 & 64.91 & 1.01 & 14. 60 & 11,850 & & \\
\hline 28 & 7.8 & 4. & 3 & 9. & 3. & 5. & 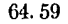 & 1.09 & 15. 49 & 11 , & $\ldots$ & \\
\hline 2 & 0 & & 9 & 13.03 & 4. 37 & 5. 11 & 2. 30 & 1.14 & 14.05 & 11,440 & ...dd & \\
\hline 23 & 5.8 & & 48.8 & 8.00 & 4. 19 & 5.14 & 67.55 & .95 & 14.17 & 12,300 & $\cdots$ & \\
\hline 24 & 6. & & & 10.20 & 3. & 5.13 & & .93 & 13.72 & & & \\
\hline 24 & 4. & 38.2 & 4 & 11. 49 & 4. & 5. & & .99 & 11. & 11 & & \\
\hline & 6 & & 4 & 8.19 & 4. & 5. 32 & p & .90 & 13.98 & 12 & & \\
\hline 178 & & & .45 .8 & 8. & 4.8 & 5. 37 & 69. 30 & 1. 20 & 10.48 & & U.S & \\
\hline & 2 & 9 & 49.9 & 9.42 & 5.09 & 5. 25 & 69.76 & 1.09 & 9.39 & 12 & Ohi & \\
\hline 11 & 4. & 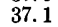 & 48. 2 & 10.61 & 4.9 & 4.8 & 68.77 & 1.10 & 9.68 & 12 & & \\
\hline 0187 & 4. & 4 & 43 & 9.3 & 4. 46 & & & & & & U. & \\
\hline 188 & & & 44.4 & 8.6 & 4. 45 & & & & & & ...d & \\
\hline 230 & & & & 9.5 & 4.57 & & & & & 12,760 & $\cdots$ & \\
\hline & 2 & 37.9 & 51.2 & 8.00 & 4.31 & 5.11 & 72.95 & 1.04 & 8.59 & 13 & $\because 0$ & \\
\hline 2095 & & & & 8.1 & & & & & & & & \\
\hline 3986 & 4 & & 48 & 8.0 & 4.1 & & & & & 13 , & $\ldots \mathrm{do}$ & \\
\hline 3988 & 3 & & 50.1 & (i. 0 & 3.42 & & & & & 13 & $\ldots \mathrm{dc}$ & \\
\hline 3 & & & 5 & 6.86 & 3. & 5.45 & 72.06 & 1. 17 & 10.70 & & & \\
\hline 4 & & & & & 4. & 5.23 & 70.57 & 1. 20 & & & & \\
\hline 7 & & & & & & 5. 14 & 71 & 1. 06 & & & & \\
\hline 10 & & & 47.0 & 11.01 & 4. & 5. 17 & 67.64 & 1. 08 & 10.43 & & & \\
\hline 6 & & & & 10.84 & 4.76 & 5.09 & 67.41 & 1.11 & 10 & & & \\
\hline 5 & 4. & & & 10.70 & & 4.85 & 68 & 1. 10 & & & & \\
\hline 1 & & & & 7. & & 5. 21 & & 1. 24 & & & & \\
\hline 2 & & & & & & 5.14 & & 1. & & & & \\
\hline $6 a$ & A & & & 10.35 & & 5.19 & 68 & 1. 09 & 11. 25 & & & \\
\hline $2 \mathrm{a}$ & 4 & & 50.2 & 9. 21 & 4. & 5.14 & 68.75 & 1.09 & 11. 64 & & & \\
\hline 3986 & & & & & 4. & & & & & & & \\
\hline & & & 49 & 9.52 & & 5.22 & 69 & 1.1 & 10 & & & \\
\hline & & & & S. 22 & 4. & 5.38 & 71.03 & 1. 26 & 10.09 & & & \\
\hline 1944 & 4. & & 53.7 & 6.0 & 1. & & & & & & & \\
\hline $15 \mathrm{a}$ & & & 54.0 & 9.00 & & 5.06 & 71.18 & 1.32 & 11.89 & & & \\
\hline & & & & 10.46 & & 5.03 & 68.01 & 1.12 & 11. 29 & & & \\
\hline 5563 & 3 & & & & & & & & & & & 53 \\
\hline 5564 & 4. & & & & & & & & & & & \\
\hline 13 & 5. & & 5 & 6. & 1. & 5.37 & 72 & 1. & 12 & 13 , & & \\
\hline 19 & 4. & 3 & & 8. & & 5.36 & 71 & 1. & 11. & & & \\
\hline 14 & & & & & & 5.18 & 71.34 & 1. 20 & 11.39 & & & \\
\hline 1910 & 4. & & & 7. & 3.67 & & & & & & & 20 \\
\hline 15486 & & & $=$ & 531 & & 5.35 & 4.13 & 1.46 & 2.77 & & & \\
\hline & & & & 8. & & & & & & & & \\
\hline 488 & 4. & & 5 & 6. & 2. & & & & & 13 & & 53 \\
\hline 489 & 4. & 36 & 51.2 & 7.25 & 2.6 & 5.36 & 71.91 & 1.38 & 11.50 & 12,990 & & 5 \\
\hline & & & & & & & & & & 13,180 & ... & \\
\hline
\end{tabular}


Analyses of Ohio coals-Continued.

Pittsburgh coal (No. 8)-Continued.

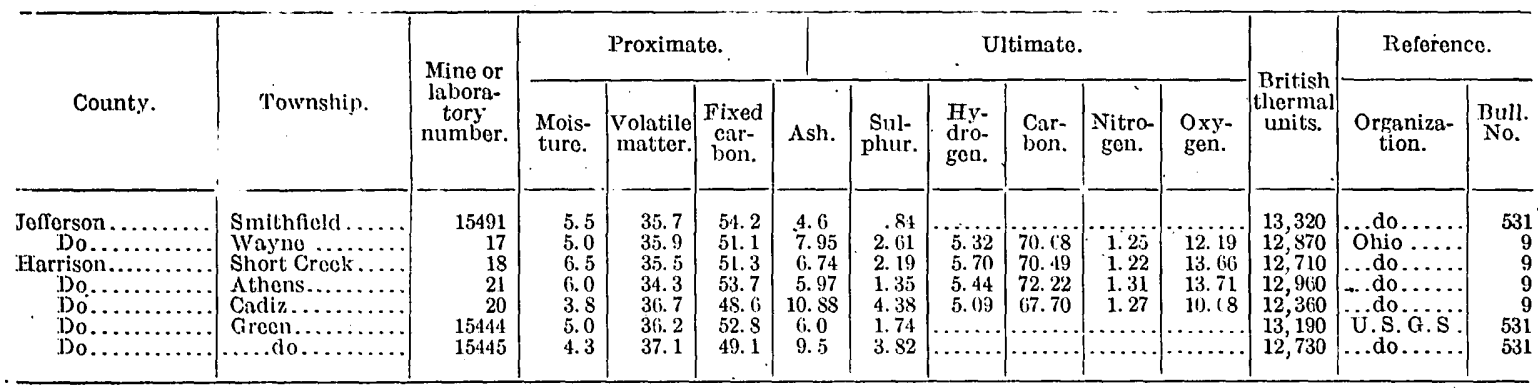

Pomeroy coal (No. 8a)

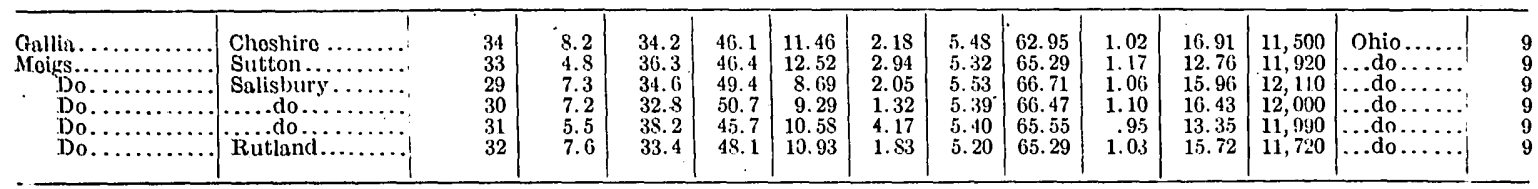

Meigs Creek coal (No. 9).

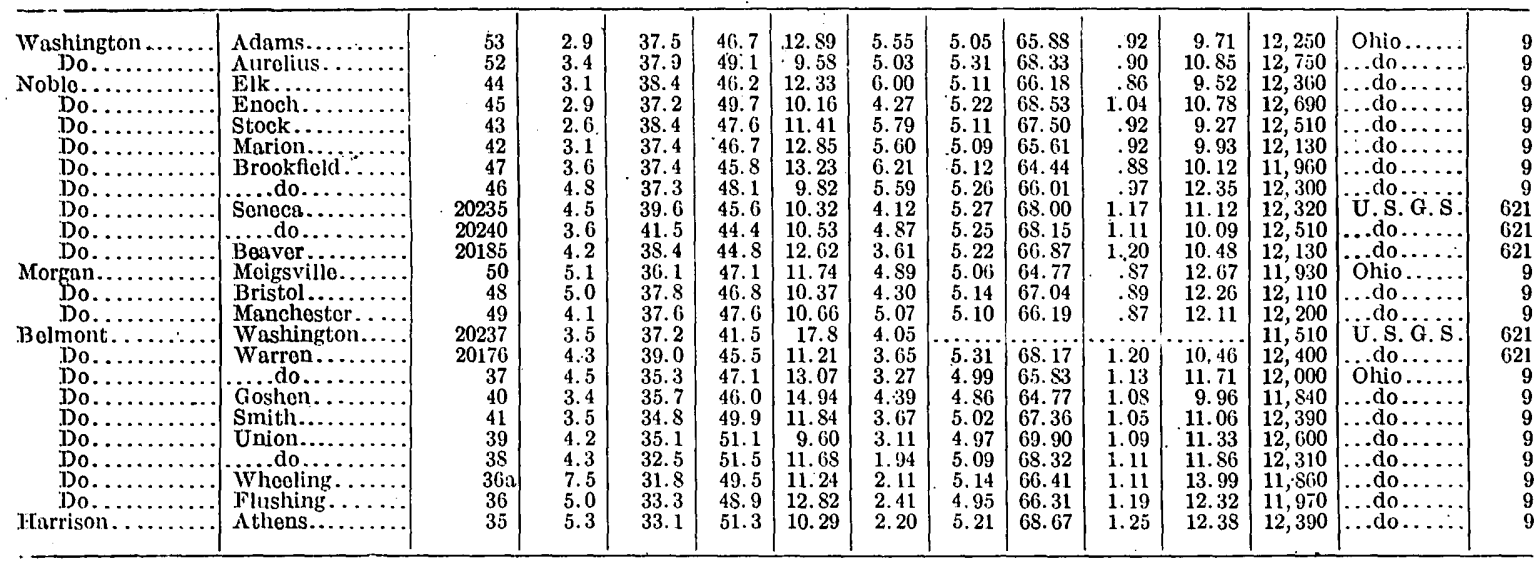

Uniontown coal.

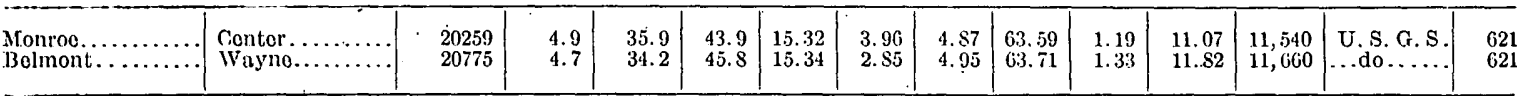

Waynesburg coal.

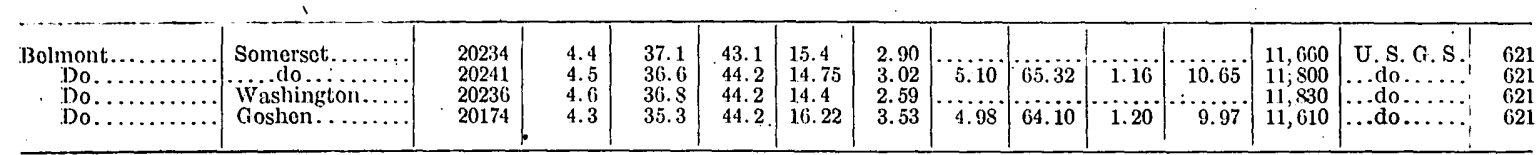

Washington coal.

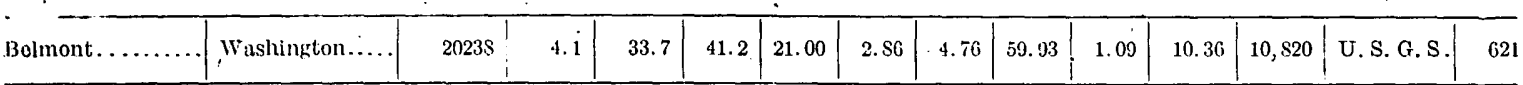

USES OF OHIO COALS.

RANGE OF THE COAIS

The coas of Ohio have nothing like the range in composition possessed by the coals of Pennsylvania and West Virginia. In Pennsylvania the varieties extend from anthracite to gas coals like the Pittsburgh, and in West Virginia all bituminous. from semibituminous coals like the Pocahontas and New River, with their low content of volatile matter and high percentage of fixed carbon, to the Pittsburgh coal, whose qualities are similar to those of the same coal in Pennsylvania. The Ohio coals, on the other hand, are 
COKE.

In former years several Ohio coals have been coked, but not a pound of coke is now made from them in the State, except possibly as a by-product. At Leetonia, Columbiana County, the Lower Kittanning coal was long coked for local use in iron furnaces, but the ovens there have not been fired for years. The coal bed was thin and therefore expensive to work, and the coke, although good, did not equal the standard Connellsville coke. The Middle Kittanning coal was formerly coked in a small way at Hammondsville, Jefferson County, but according to Orton it is too high in ash and sulphur. Moreover, the coal in that locality does not exceed 30 inches in thickness.

The Freeport coals have both been the basis of a small coking industry. The Lower Freeport coal was used for many years for this purpose at Steubenville and yielded a fair coke, but the industry fell into decay, and Pennsylvania coke has taken the place of the product. Slack coal from the Upper Freeport bed was formerly coked at Salineville, but the product was of poor quality. The same bed was once coked at Happy Hollow in western Athens County, but the coal was dirty and high in sulphur, and the coke could not be used where a first-class product was required.

The Pittsburgh coal has been coked on a large scale in Ohio, but the product is not equal to that made in the vicinity of Connellsville, Pa., or along New River, W. Va. The coal is too high in sulphur, but this difficulty might be overcome by washing. A dozen ovens were once in operation in the valley of Wheeling Creek a few miles west of Bridgeport. Slack coal only seems to have been used, but the market for the product was small. Near Utley, in northern Athens County, coke was made from the Pittsburgh coal. About 125 ovens were built, but probably not more than 50 of them were used at any one time, and the last were abandoned nearly 20 years ago. Lathrop, which is a few miles north of Utley, has 50 ovens, but except possibly for a short period in 1907 or 1908 they have not been in use for many years. Slack coal was used at Utley; the lump being thought too expensive. The coke is reported to have found a ready market in several large western cities, but the coal is too .high in sulphur to make first-class coke.
RAW COAL FOR FURNACE USE.

The Sharon coal in the natural state is still used at Jackson for making pig iron. The Wellston coal, according to Orton, was formerly used for the same purpose, but it appears to be too high in sulphur and has not been used in iron making for a long time. The Sharon coal in northern Ohio, and especially that of the Mahoning Valley, was once used on a large scale in the blast furnaces of that locality. It was excellent for the purpose, but the bed was thin and the coal, good as it was, did not compare with Connellsville coke for iron making. The Middle Kittanning coal in the Hocking Valley had about 35 years ago a large market in the natural state for use in local blast furnaces. Iron ore was obtained from the same territory, and for a time the industry flourished, but the ores could not compete with those from Michigan, nor was the coal as fuel equal to coke from Pennsylvania, and the industry was short lived.

\section{DOMESTIC USE.}

Every coal in Ohio is used for domestic purposes and choice is largely a question. of market conditions. The Sharon and Quakertown coals are most prized for this purpose of all the coals of Ohio, and they rank among the best in this country. The Middle Kittanning coal has a large sale for this use. It is among the strongest of the Ohio coals and hence has relatively little slack. It generates a large amount of heat and carries only a moderate percentage of sulphur, but unless the miners are careful shale or clay may be loaded with coal, which thus increases the ash and possibly forms clinker. The Pittsburgh coal also has a large market for domestic use. It is easily ignited, makes a good heat, and is moderate in ash and sulphur, but its tendency to fuse and cut off the draft is objectionable.

\section{GAS MAKRNG.}

Before the advent of natural gas various Ohio coals were used for gas making. Probably the coal from the Middle Kittanning bed had the most extensive market for this purpose, but this may have been due to its having been worked in a larger way than other Ohio coals. The coal is high in volatile matter, but the residue makes a very poor coke, 
which of course operates against the bed. Probably the Pittsburgh coal is the best of the large deposits of Ohio for making gas. It is high - in volatile matter and makes better coke than any other Ohio coal of a similar quantity. When the natural gas supply in Ohio has failed, as it will in the near future, the better grades of Pittsburgh coal will, in all probability, find a large market for gas making.

\section{STEAM RAISING.}

Every conl in Ohio that has workable thickness under existing conditions is used for steam production, and whether one coal or another is used depends largely on the price. However, large purchasers are now taking into consideration the quality of the coal, and especially its heating value, sulphur, and ash. The following figures, taken almost wholly from the records of the Ohio Geological Survey, furnish data on these points:

Quality of Ohio coals.

\begin{tabular}{|c|c|c|c|}
\hline Coal bed. & $\Lambda$ shl. & $\begin{array}{l}\text { Sul- } \\
\text { phur. }\end{array}$ & B.t. u. \\
\hline 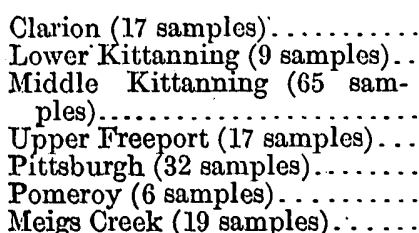 & $\begin{array}{r}10.8 \\
7.9 \\
\\
7.4 \\
9.0 \\
9.1 \\
10.6 \\
11.6\end{array}$ & $\begin{array}{l}\text { 4. } 33 \\
\text { 3. } 26 \\
\\
\text { 3. } 30 \\
2.54 \\
\text { 3. } 81 \\
2.42 \\
\text { 4. } 28\end{array}$ & $\begin{array}{l}11,950 \\
12,580 \\
12,560 \\
12,870 \\
12 ; 560 \\
11,870 \\
12,240\end{array}$ \\
\hline
\end{tabular}

However, the composition of Ohio coals varies considerably from place to place and in places from mine to mine. Thus the Clarion coal, which is important in only four counties in the southern part of the State, ranges in heat value (rejecting one sample taken from a werthered surface) from 11,130 to 12,530 B.t.u., in sulphur from 2.81 to 6.14 , and in ash from 6.2 to 15.3 per cent. This coal is high in both sulphur and ash, and its heat value is not so high as that of most Ohio coals. Nevertheless, it finds a market for steam generation, and this market will doubtless improve as the better coals are worked out. The Lower Kittanning coal is more regular. Its quality is best in the northeastern part of the State, as the table of analyses shows, but unfortunately its quantity is not large.
The great Middle Kittanning bed, noted for its regularity, shows but slight changes from Columbiana County southwestward to Ohio River. Its quality is shown in the following table:

Quality of the Middle Kittanning coal bed from Columbiana County southwestward to Ohio River.

\begin{tabular}{|c|c|c|c|}
\hline County or field. & Ash: & $\begin{array}{l}\text { Sul- } \\
\text { phur. }\end{array}$ & B.t.u. \\
\hline 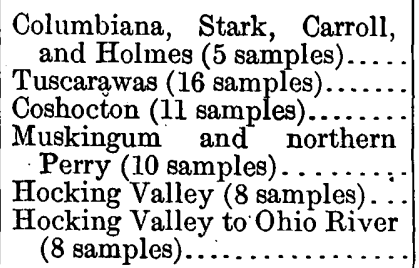 & $\begin{array}{l}6.8 \\
7.3 \\
6.8 \\
\text { 8. } \\
6.2 \\
\text { 8. } 2\end{array}$ & $\begin{array}{l}2.51 \\
3.85 \\
3.82 \\
3.72 \\
1.22 \\
\text { 3. } 21\end{array}$ & $\begin{array}{l}12,900 \\
12,800 \\
12,550 \\
12,310 \\
12,500 \\
12,430\end{array}$ \\
\hline
\end{tabular}

According to the figures given above, this coal has the highest heat value in the northeastern part of the State and decreases to the southwest all the way to Ohio River, except in the Hocking Valley field, where this value is a little higher than in the adjacent areas on the north and south. The figures for the Hocking Valley field also show the lowest percentage of ash and a sulphur percentage less than half that of the next lowest.

The Middle Kittanning coal has long had an extensive market for steam purposes. It is open burning and therefore does not cut off the draft. However, unless the shale partings and pyrite are carefully sorted out, clinkers form, which reduce the draft and may ruin the grate bars. The coal is tough and strong and forms less slack than most Ohio coals. Its heat value is good, and it is moderate in both ash and sulphur.

The Upper Freeport coal shows a greater range in quality than the Middle Kittanning, as indicated below:

Quality of the Upper Freeport coal.

\begin{tabular}{|c|c|c|c|}
\hline Counties. & Ash. & Sulphur. & B.t. u. \\
\hline 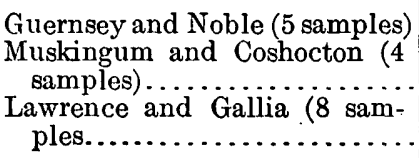 & $\begin{array}{r}7.8 \\
7.8 \\
10.3\end{array}$ & $\begin{array}{l}3.01 \\
3.80 \\
1.62\end{array}$ & $\begin{array}{l}12,720 \\
12,540 \\
11,710\end{array}$ \\
\hline
\end{tabular}


The Upper Freeport coal is more distinctly a steam coal than any other in Ohio. In fact, steam making is its one great use. It does not make a good coke, is too high in sulphur for furnace use, and forms too much slack for domestic purposes. The coal from the Cambridge field is one of the best, viewed from the standpoint of heating value, and the sulphur and ash are not excessive.

As stated on the preceding page the Pittsburgh coal forms three distinct fields, and the average quality of the coal in each field is shown below:

Quality of the Pittsburgh coal.

\begin{tabular}{c|r|r|r}
\hline Field. & \multicolumn{1}{|c|}{ Ash. } & Sulphur. & B. t. u. \\
\hline Belmont (24 samples).......... & 8.8 & 3.71 & 12,780 \\
Federal Creek (4 samples).... & 9.5 & 4.18 & 12,060 \\
Swan Creek (4 samples)...... & 10.5 & 4.45 & 11,720 \\
\hline
\end{tabular}

These analyses show that this coal deteriorates toward the southwest. The Pittsburgh coal has a large market for steam making for both locomotives and stationary boilers. It is excellent for this purpose, though its tendency to fuse in burning may reduce the draft.

The Pomeroy coal is high in ash, averaging over 10 per cent, but it is lower in sulphur than the Pittsburgh coal, and has fair heating power. It also is well adapted to the generation of steam.

The Meigs Creek coal, the highest stràtigraphically of the important beds in Ohio, ranks well in heating value, but it is high in both sulphur and ash and therefore is not the equal of most other Ohio coals for steam production.

\section{BIBLIOGRAPHY.}

Geological Survey of Ohio:

Reports of progress for 1869 (1871) and 1870 (1871).

Volume I (1873), II (1874); III (1878), V (1884), VI (1888), and VII (maps) (1893).

Bulletins 7 (1905), 9 (1908), 17 (1912), and 20 (1916). Geological map of Ohio (1909).

Ohio Mining Journal, 1883 to 1898.

Ohio State University Bulletin, volume 18, No. 32 (1914).

United States Geological Survey:

Twenty-second Annual Report (1901).

Bulletins 65 (1881), 290 (1906) and 349 (1908).

Folios 69 (1900) and 184 (1912).

Mineral Resources of United States (1882-1915).

United States Bureau of Mines: Bulletins 22 (1913), 85 (1914), and 119 (1916).
ORIGINAL COAL CONTENT OF THE FIELDS.

\author{
By Frank R. Clark.
}

INTRODUCTION.

The coal tonnage of any field is hard to ascertain and may be very differently estimated, even by geologists or engineers using the same set of facts. The estimate herein made is based not on original field work by the author but on a careful study of the facts contained in the reports of the Ohio Geological Survey. The writer's estimate, $87,638,000,000$ short tons, is so much higher than any heretofore published that it seems to require an explanation and a careful statement as to its basis and of the manner of its computation.

Three factors have contributed more or less to make the writer's estimate larger than that of others who have essayed to make an inventory of the available coal of Ohio. These factors are (1) the inclusion in the present estimate of the tonnage of coal contained in beds below drainage level, (2) the fixing of a minimum thickness considerably below that which is now considered to be the limit of workability, and (3) the estimation of the original tonnage before. mining began rather than that which is still available in the ground. The estimates made by the United States Geological Survey are based on the principle that they should include all coal beds that ever will be mined, regardless of present mining conditions; consequently beds below drainage level, unless they lie at a depth of 5,000 or 6,000 feet, should be considered just as much as those exposed in outcrop, and thin beds should be included as well as thick beds, for sooner or later all will be required to help satisfy the world's demand for fuel. The fixing of a minimum thickness below that which is to-day considered the limit of workability is of course open to question, but the minimum limit fixed, 14 inches, was adopted for all high-rank coal after consideration of thin coal beds mined at present both in this country and abroad. Possibly beds even thinner than 14 inches may be worked when all the thick beds have been exhausted.

The estimate here given was made in 1912 in connection with a computation of the coal resources of the United States and was first published in the "Coal resources of the world" as a part of the proceedings of the Twelfth Interna- 
tional Geological Congress at Ottawa, Canada, in 1913. The figures given in that report, $93,967,916,000$ short tons, have been somewhat modified on account of new information regarding the absence of coal where it was for merly supposed to be present ${ }^{1}$ and by giving tonnage figures in round numbers to the nearest million.

\section{DATA ON WHICH ESTIMATES ARE BASED.}

The data used in making the estimate were taken from the Geological Survey of Ohio reports for 1869 and 1870 (two volumes), for 1873 to 1893 (vols. 1 to 7 , inclusive), and from Coal Bulletin 9, 1908, Oil and Gas Bulletin 1, 1903, and Bulletin 20 (4th series), 1916. In addition to the data in these reports some information regarding the counties adjoining Ohio on the east was obtained from the reports published by the Geological Survey of Pennsylvania and by that of West Virginia.

Although the Ohio reports are voluminous, much of the material contained in them, especinlly in the earlier ones, is indefinite, because it does not indicate the exact locations of all the measured conl sections and because the maps do not show the outcrops of all the coal beds. At the time these estimates were made (1.912) the only maps available were those (Nos. 1. to 10 , inclusive) accompanying volume 7 (Reports for 1873-1893) and two others in Bulletin 9. These maps show the position of the base of the coal measures and the outcrops of the Middle Kittanning, Upper Freeport, Pittsburgh, Pomeroy, and Meigs Creek coal beds. They represent the probable area of the coal beds above drainage level, but they do not show how far below drainage any of the beds may extend.

All data obtained from the various sources named regarding the thickness of the coal beds (every recorded section being used), the regular or irregular habit of any particular bed, and the probable area underlain by each bed were properly tabulated under beds, townships, and counties.

\section{METHODS OF COMPUTATION.}

The nature of the data makes it necessary to divide the work of computation into two parts(1) estimates of beds whose outcrops have been

"This zone of barren territory or "frult" in the Focking Valley coal flold is shown in Pl. III of this report. mapped and (2) estimates of beds whose outcrops have not been mapped and whose areas had to be estimated from the facts recorded in the text. As the Lower Kittanning lies only a short distance below the Middle Kittanning, and the Lower Freeport only a short distance below the Upper Freeport, the outcrops of each group were assumed to be essentially parallel.

All the detailed sections of a particular coal bed were first averaged by townships. Then all these township averages and the sections in adjoining township of other counties were again averaged to obtain the average thickness for the county. The probable area underlain by the coal bed was carefully measured with a planimeter from the maps showing the coal outcrops. The part of the total area lying above drainage level was taken directly from the coal maps, and the part lying below drainage level was estimated on the assumption (in the absence of definite measurements) that a coal bed which is persistent along its outcrop and reasonably constant in thickness will have approximately the same average thickness below drainage level that it has above that level. In the absence of positive evidence that coal is not present it was also assumed that a bed may extend below drainage level toward the center of the main coal basin at right angles to the strike of the beds for a distance equal to that through which it is known to extend above drainage level. Suoh an assumption, though altogether arbitrary, is at least reasonable and conservative. Concerning it.as well as the other assumptions differences of opinion may exist, because they can not be based on hard and fast rules. Obviously, however, there is no good reason for assuming that coal beds Jying in relatively undisturbed areas are absent below drainage level simply because their presence has not been proved by mining or drilling. The making of an estimate where the bed lies above drainage level is also attended with difficulties, for here one must also assume that the coal is present or absent, and if the former that it continues at about the average thickness in areas concerning which little or no information is available. The determination of the average thiokness of a coal bed as well as its areal extent was greatly facilitated at many points by records of deep borings published in the State reports.

The coal beds which contribute more or less to the total coal of Ohio but which are not 
shown in outcrop on any of the maps published before 1912 are the Sharon, Wellston (Quakertown), Lower Mercer, Upper Mercer, Tionesta, Brookville, Clarion, Wilgus, Brush Creek (coals $7 \mathrm{a}$ and $7 \mathrm{~b}$ ?), Jeffers, coal No. 10 (wanting in Pennsylvania), Waynesburg (coal No. 11), and Brownsville (coal No. 12). The determination of the probable areas underlain by each of these coal beds was very difficult and unsatisfactory. The areas were obtained with the aid of maps showing the outcrop of the base of the coal measures, the outcrops of the more important coal beds, the location of coal sections, the records of deep borings, and references in the text of the State reports.

The average thickness of each of the coal beds mentioned above in any unit of area (such as the county, township, or less) was obtained by averaging all the sections of coal affecting any one unit area in the same manner as that described for the more important beds.

With the area and thickness of the coal bed determined the next step was to determine the weight. Coal varies somewhat in weight, but the average of most bituminous coals with an ash content of not more than 8 per cent has a specific gravity of about 1.3. This means that an acre-foot of coal will weigh about 1,800 short tons and that a square-mile-foot will weigh about 1,152,000 short tons. These figures multiplied by the average thickness of the bed expressed in feet gives the tonnage of the coal bed under an acre or a square mile of ground.

\section{THE ESTRMATES.}

The following table gives the tonnage by beds and counties. The first column gives the name of the coal bed; the second, the calculated average thickness in feet and inches; the third, the area in square miles considered to contain the coal bed with the average thickness shown in column 2; the fourth, the tons per square mile corresponding to each thickness given in column 2 ; the fifth, the product in round numbers to the nearest million of the figures in columns 3 and 4 ; and the sixth, the sum of all figures in column 5 . This table contains the tonnage of 20 coal beds which contribute more or less to the fuel supply of the State, and one or more of the beds is considered to be present in 31 counties in eastern Ohio.

Estimated coal tonnage by beds and counties.

Athens County.

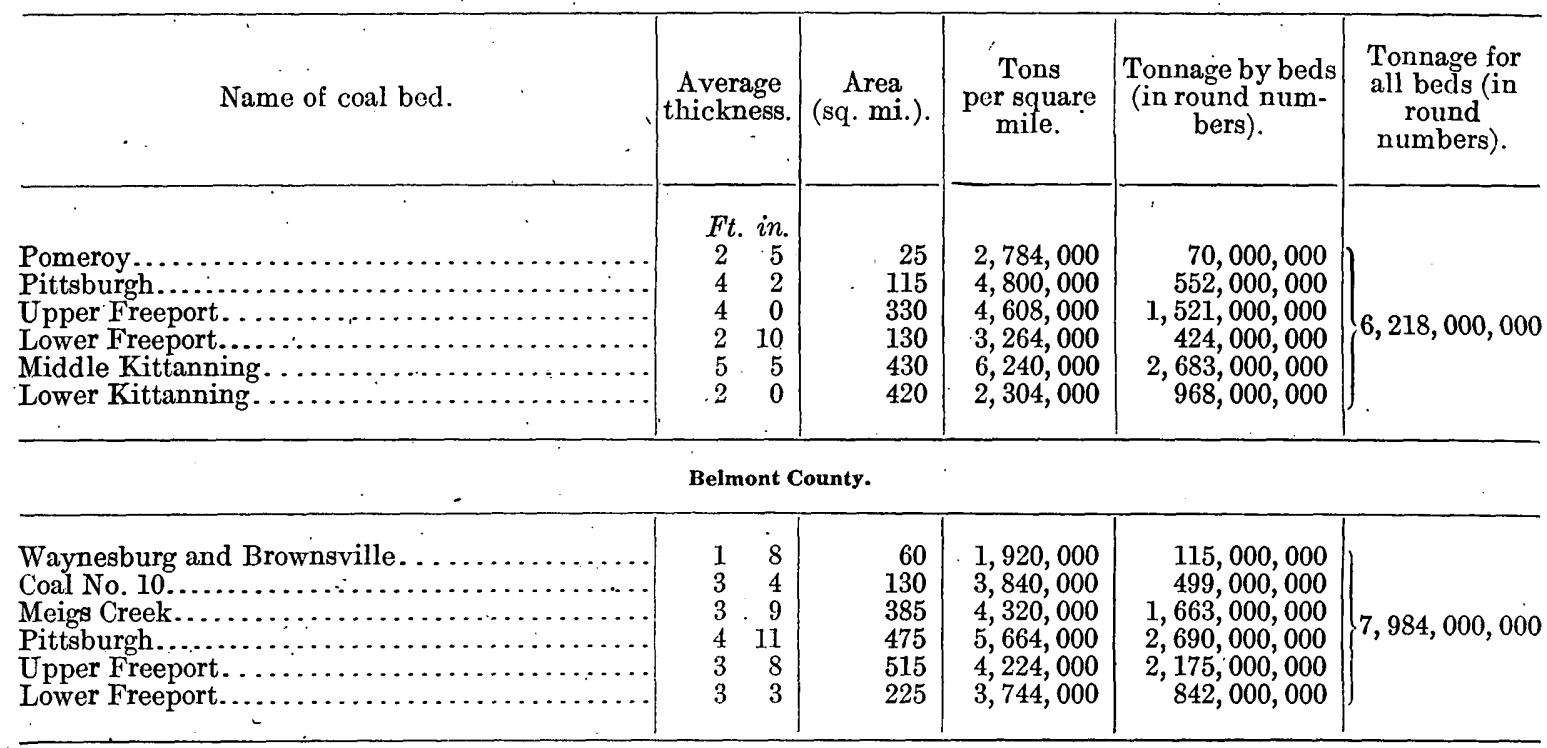


Estimated coal tonnage by beds and counties-Continued.

Carroll County.

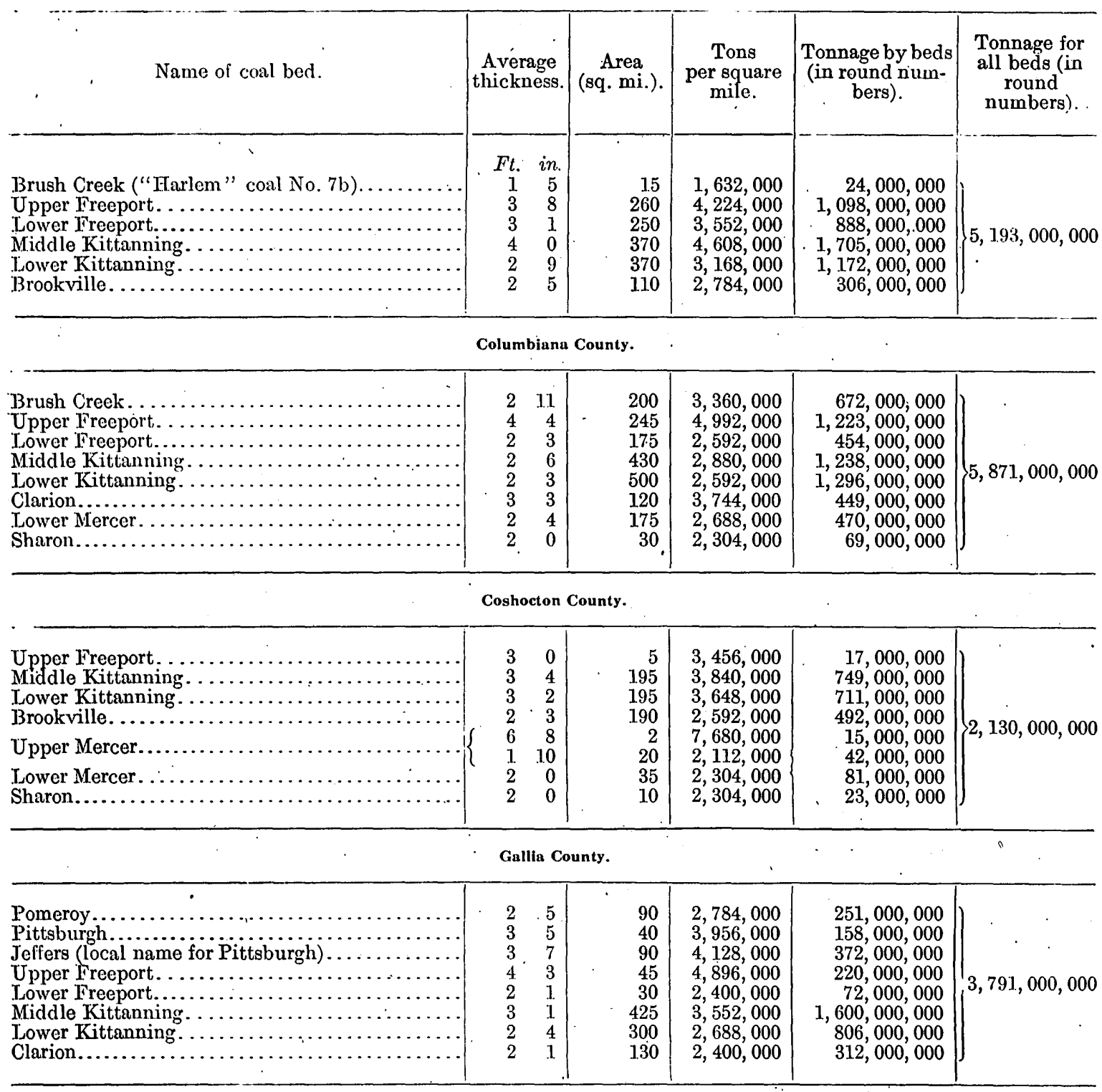

Guernsey County.

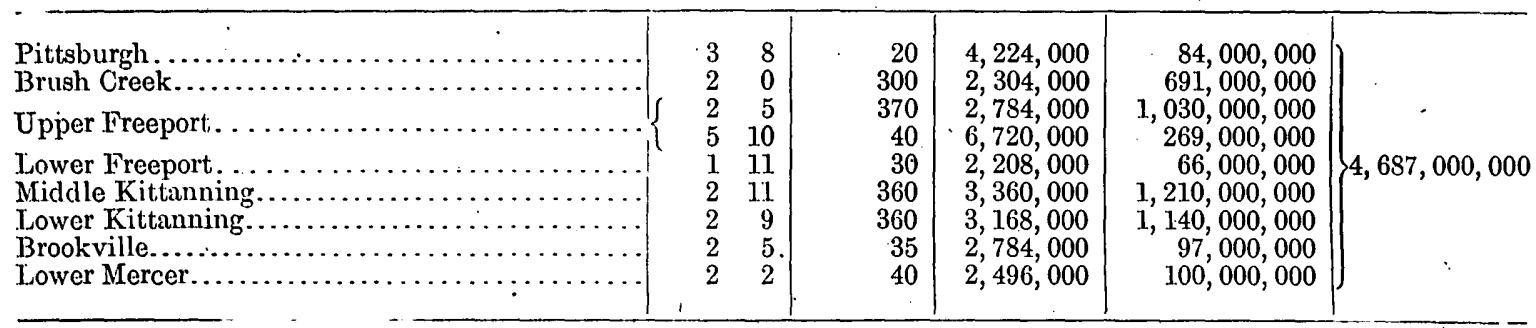


Harrison County.

\begin{tabular}{|c|c|c|c|c|c|}
\hline Name of coál bed. & $\begin{array}{c}\text { Average } \\
\text { thickness. }\end{array}$ & $\begin{array}{c}\text { Area } \\
\text { (sq. mi.). }\end{array}$ & $\begin{array}{l}\text { Tons } \\
\text { per square } \\
\text { mile. }\end{array}$ & $\begin{array}{l}\text { Tonnage by beds } \\
\text { (in round num- } \\
\text { bers). }\end{array}$ & $\begin{array}{l}\text { Tonnage for } \\
\text { all beds (in } \\
\text { round } \\
\text { numbers). }\end{array}$ \\
\hline 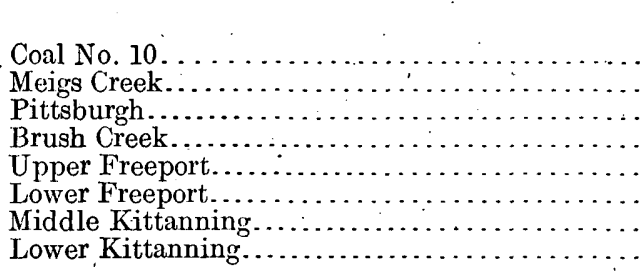 & $\begin{array}{rr}\text { Ft. } & \text { in. } \\
1 & 10 \\
4 & 2 \\
4 & 11 \\
2 & 5 \\
3 & 4 \\
3 & 0 \\
4 & 0 \\
3 & 0\end{array}$ & $\begin{array}{r}30 \\
30 \\
110 \\
70 \\
295 \\
265 \\
315 \\
315\end{array}$ & $\begin{array}{l}2,112,000 \\
4,800,000 \\
5,664,000 \\
2,784,000 \\
3,840,000 \\
3,456,000 \\
4,608,000 \\
3,456,000\end{array}$ & $\begin{array}{r}63,000,000 \\
144,000,000 \\
623,000,000 \\
195,000,000 \\
1,133,000,000 \\
916,000,000 \\
1,452,000,000 \\
1,089,000,000\end{array}$ & $5,615,000,000$ \\
\hline \multicolumn{6}{|c|}{ Hocking County. } \\
\hline 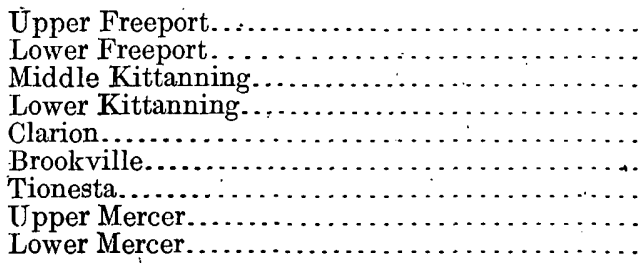 & $\begin{array}{ll}3 & 6 \\
3 & 4 \\
6 & 3 \\
2 & 3 \\
2 & 6 \\
2 & 0 \\
2 & 9 \\
1 & 4 \\
2 & 0\end{array}$ & $\begin{array}{r}10 \\
10 \\
40 \\
45 \\
5 \\
10 \\
50 \\
20 \\
45\end{array}$ & $\begin{array}{l}4,032,000 \\
3,840,000 \\
7,200,000 \\
2,592,000 \\
2,880,000 \\
2,304,000 \\
3,168,000 \\
1,536,000 \\
2,304,000\end{array}$ & $\begin{array}{r}40,000,000 \\
38,000,000 \\
288,000,000 \\
117,000,000 \\
14,000,000 \\
23,000,000 \\
158,000,000 \\
31,000,000 \\
104,000,000\end{array}$ & $813,000,000$ \\
\hline \multicolumn{6}{|c|}{ Holmes County. } \\
\hline 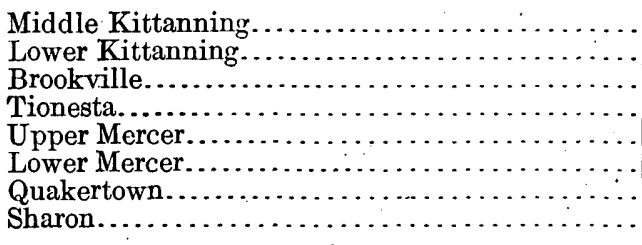 & $\begin{array}{rr}3 & 4 \\
2 & 11 \\
2 & 0 \\
2 & 6 \\
3 & 2 \\
3 & 0 \\
2 & 0 \\
2 & 0\end{array}$ & $\begin{array}{r}30 \\
30 \\
20 \\
5 \\
40 \\
80 \\
55 \\
50\end{array}$ & $\begin{array}{l}3,840,000 \\
3,360,000 \\
2,304,000 \\
2,880,000 \\
3,648 ; 000 \\
3,456,000 \\
2,304,000 \\
2,304,000\end{array}$ & $\begin{array}{r}115,000,000 \\
101,000,000 \\
46,000,000 \\
14,000,000 \\
146,000,000 \\
276,000,000 \\
127,000,000 \\
115,000,000\end{array}$ & $940,000,000$ \\
\hline \multicolumn{6}{|c|}{ Jackson County. } \\
\hline 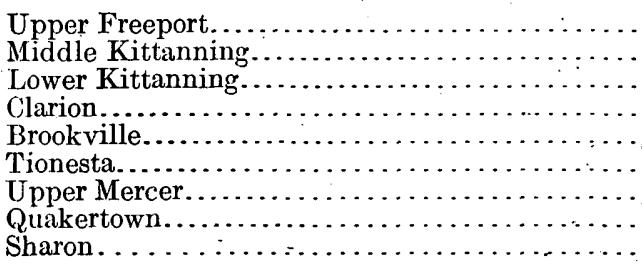 & $\begin{array}{rr}5 & 2 \\
2 & 0 \\
2 & 11 \\
3 & 7 \\
2 & 0 \\
2 & 0 \\
1 & 4 \\
2 & 8 \\
2 & 7\end{array}$ & $\begin{array}{r}1 \\
40 \\
50 \\
80 \\
5 \\
5 \\
10 \\
120 \\
40\end{array}$ & $\begin{array}{l}5,952,000 \\
2,304,000 \\
3,360,000 \\
4,128,000 \\
2,304,000 \\
2,304,000 \\
1,536,000 \\
3,072,002 \\
2,976,000\end{array}$ & $\begin{array}{r}6,000,000 \\
92,000,000 \\
168,000,000 \\
330,000,000 \\
12,000,000 \\
12,000,000 \\
15,000,000 \\
369,000,000 \\
119,000,000\end{array}$ & $1,123,000,000$ \\
\hline \multicolumn{6}{|c|}{ Jefferson County. } \\
\hline 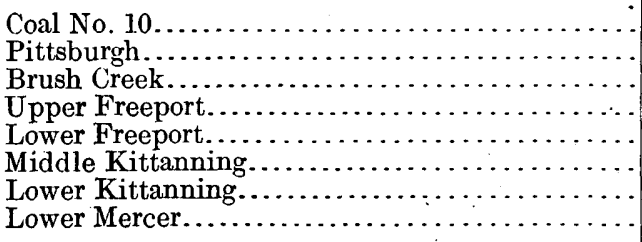 & \begin{tabular}{rr|}
1 & 6 \\
4 & 11 \\
3 & 2 \\
3 & 5 \\
4 & 0 \\
2 & 8 \\
2 & 6 \\
2 & 7
\end{tabular} & $\begin{array}{r}20 \\
110 \\
155 \\
130 \\
380 \\
395 \\
395 \\
50\end{array}$ & $\begin{array}{l}1,728,000 \\
5,664,000 \\
3,648,000 \\
3,936,000 \\
4,608,000 \\
3,072,000 \\
2,880,000 \\
2,976,000\end{array}$ & $\begin{array}{r}35,000,000 \\
623,000,000 \\
565,000,000 \\
512,000,000 \\
1,751,000,000 \\
1,213,000,000 \\
1,138,000,000 \\
149,000,000\end{array}$ & $5,986,000,000$ \\
\hline
\end{tabular}


Estimated coal tonnage by beds and counties-Continued

Lawrence County.

Name of coal bed.
$\ldots$
$\ldots$
$\ldots$

Licking County.

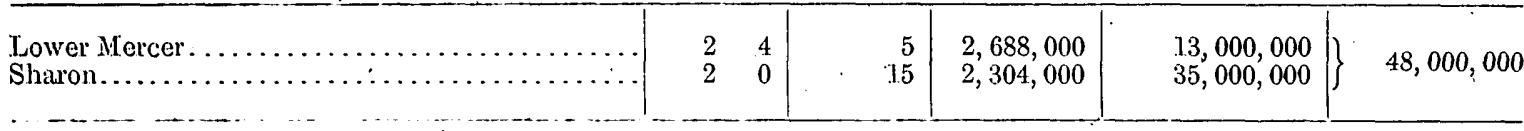

Mahoning County.

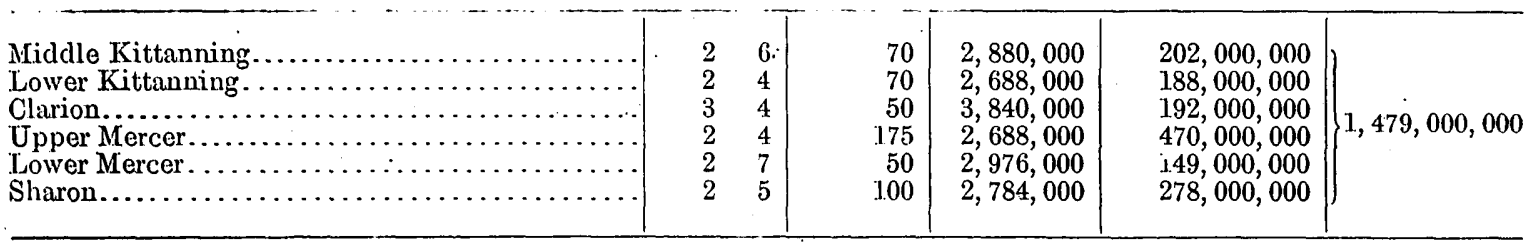

Medina County.

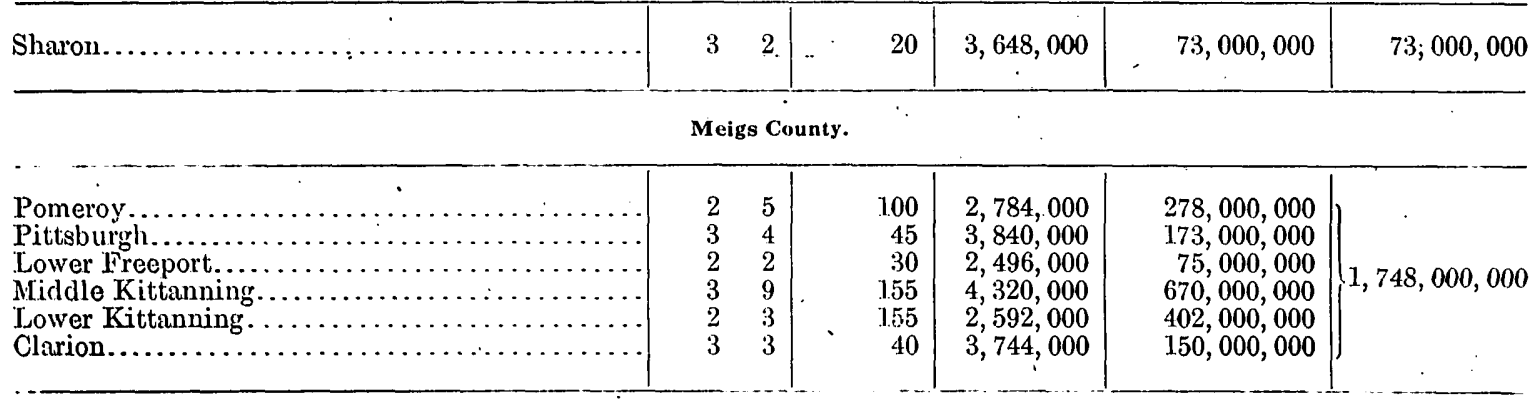

Monroe County.

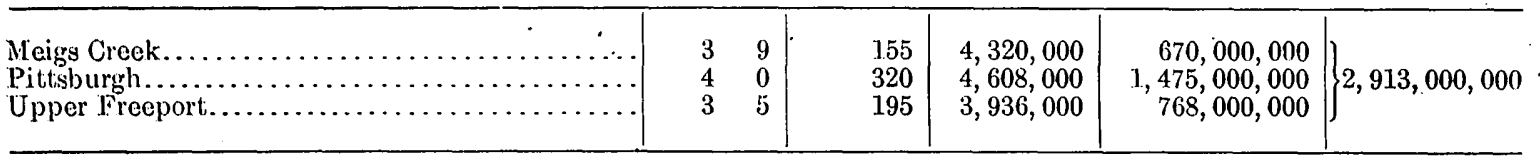

Morgan County.

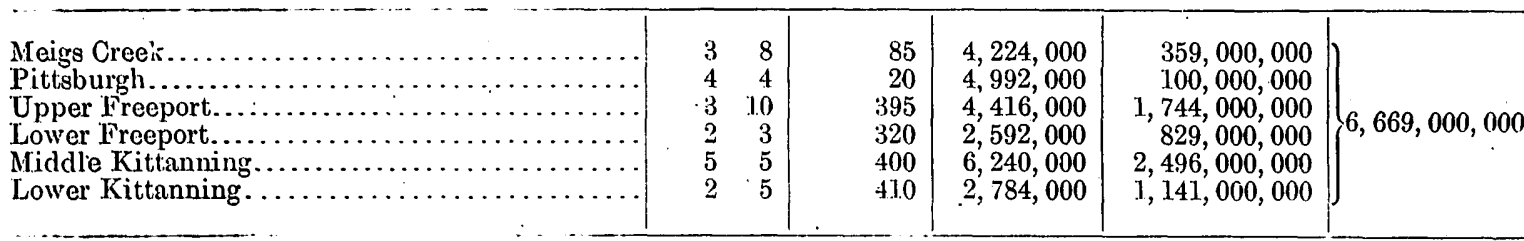


Estimated coal tonnage by beds and counties-Continued.

Muskingum County.

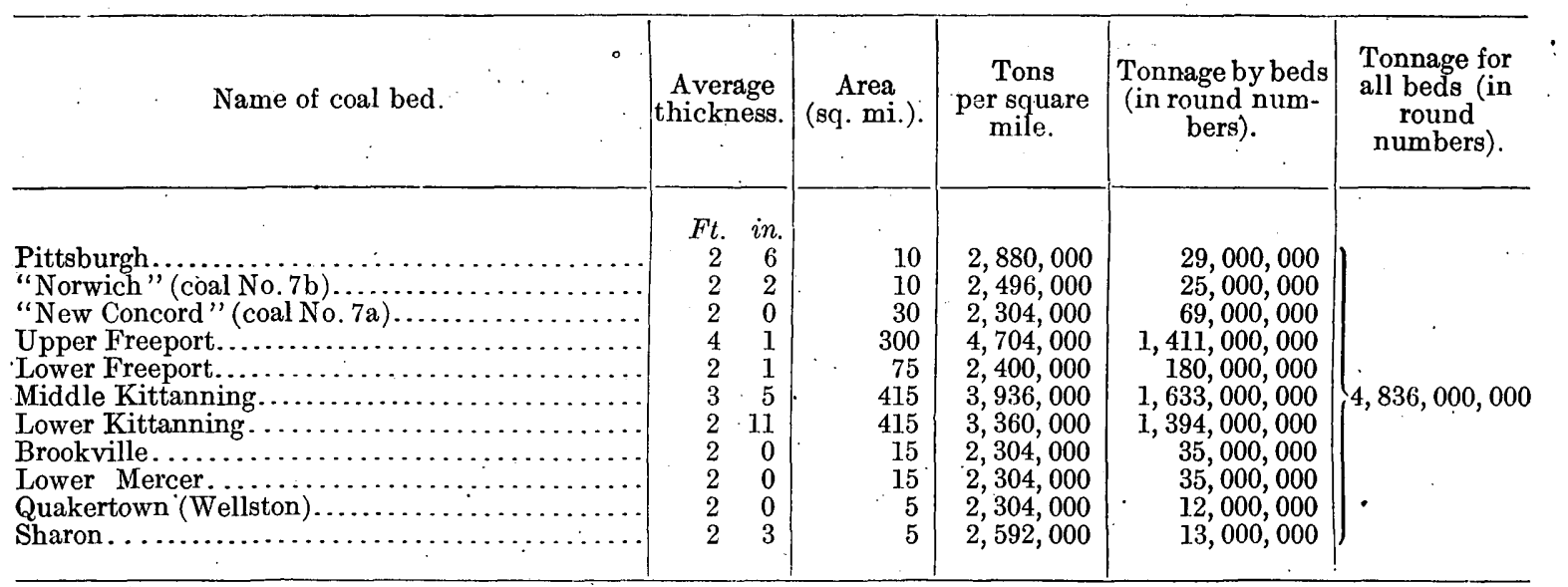

Noble County.

\begin{tabular}{|c|c|c|c|c|c|}
\hline 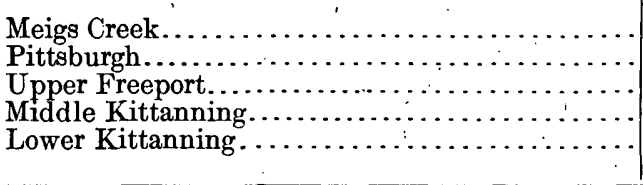 & $\begin{array}{ll}4 & 4 \\
3 & 9 \\
4 & 3 \\
2 & 3 \\
2 & 0\end{array}$ & $\begin{array}{r}155 \\
5 \\
405 \\
30 \\
30\end{array}$ & $\begin{array}{l}4,992,000 \\
4,320,000 \\
4,896,000 \\
2,592,000 \\
2,304,000\end{array}$ & $\begin{array}{r}774,000,000 \\
22,000,000 \\
1,983,000,000 \\
78,000,000 \\
69,000,000\end{array}$ & $2,926,000,000$ \\
\hline$\cdot$ & \multicolumn{3}{|c|}{ Perry County. } & \\
\hline 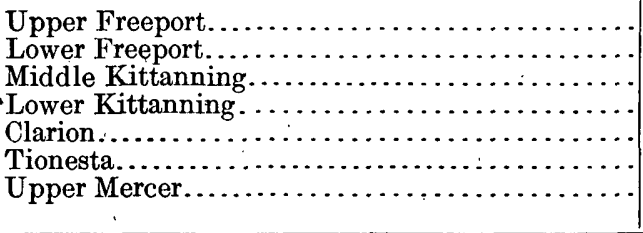 & $\begin{array}{rr}4 & 10 \\
3 & 11 \\
6 & 1 \\
2 & 9 \\
1 & 5 \\
2 & 0 \\
1 & 7\end{array}$ & $\begin{array}{r}60 \\
60 \\
120 \\
145 \\
80 \\
30 \\
20\end{array}$ & $\begin{array}{l}5,568,000 \\
4,512,000 \\
7,008,000 \\
3,168,000 \\
1,632,000 \\
2,304,000 \\
1,824,000\end{array}$ & $\begin{array}{r}334,000,000 \\
271,000,000 \\
841,000,000 \\
459,000,000 \\
131,000,000 \\
69,000,000 \\
36,000,000\end{array}$ & $2,141,000,000$ \\
\hline . & \multicolumn{2}{|c|}{ Portage County. } & \multicolumn{2}{|r|}{ ' } & . \\
\hline 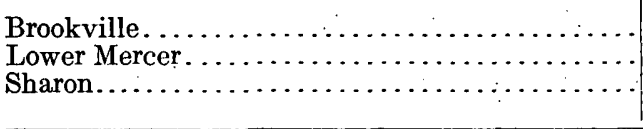 & $\begin{array}{r}4 \\
2 \\
2\end{array}$ & $\begin{array}{l}10 \\
10 \\
30\end{array}$ & $\begin{array}{l}5,184,000 \\
2,304,000 \\
2,496,000\end{array}$ & $\begin{array}{r}52,000,000 \\
23,000,000 \\
75,000,000 \\
\end{array}$ & $150,000,000$ \\
\hline \multicolumn{6}{|c|}{ Scioto County. } \\
\hline 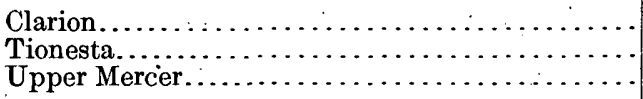 & $\begin{array}{ll}3 & 7 \\
1 & 9 \\
1 & 9\end{array}$ & $\begin{array}{l}10 \\
20 \\
15\end{array}$ & $\begin{array}{l}4,128,000 \\
2,016,000 \\
2,016,000\end{array}$ & $\begin{array}{l}41,000,000 \\
60,000,000 \\
30,000,000\end{array}$ & $131,000,000$ \\
\hline \multicolumn{6}{|c|}{ Stark County. } \\
\hline 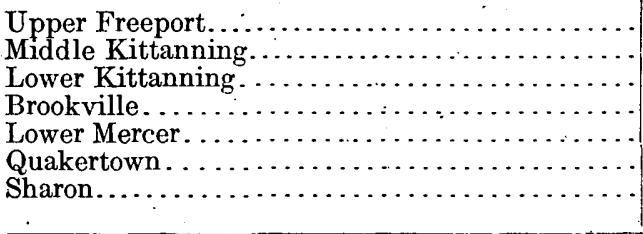 & $\begin{array}{ll}2 & 9 \\
3 & 3 \\
3 & 3 \\
2 & 7 \\
2 & 2 \\
2 & 0 \\
3 & 2\end{array}$ & $\begin{array}{r}5 \\
10.0 \\
100 \\
150 \\
50 \\
20 \\
135\end{array}$ & $\begin{array}{l}3,168,000 \\
3,744,000 \\
3,744,000 \\
2,976,000 \\
2,496,000 \\
2,304,000 \\
3,648,000\end{array}$ & $\begin{array}{r}16,000,000 \\
374,000,000 \\
374,000,000 \\
446,000,000 \\
125,000,000 \\
46,000,000 \\
492,000,000\end{array}$ & $\left\{\begin{array}{c}1,873,000,000 \\
.\end{array}\right.$ \\
\hline \multicolumn{6}{|c|}{ Summit County. } \\
\hline 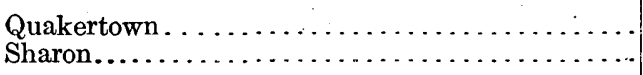 & $\begin{array}{ll}2 & 6 \\
3 & 2\end{array}$ & $\begin{array}{r}30 \\
125\end{array}$ & $\begin{array}{l}2,880,000 \\
3,648,000\end{array}$ & $\begin{array}{r}86,000,000 \\
456,000,000\end{array}$ & $\{542,000,000$ \\
\hline
\end{tabular}




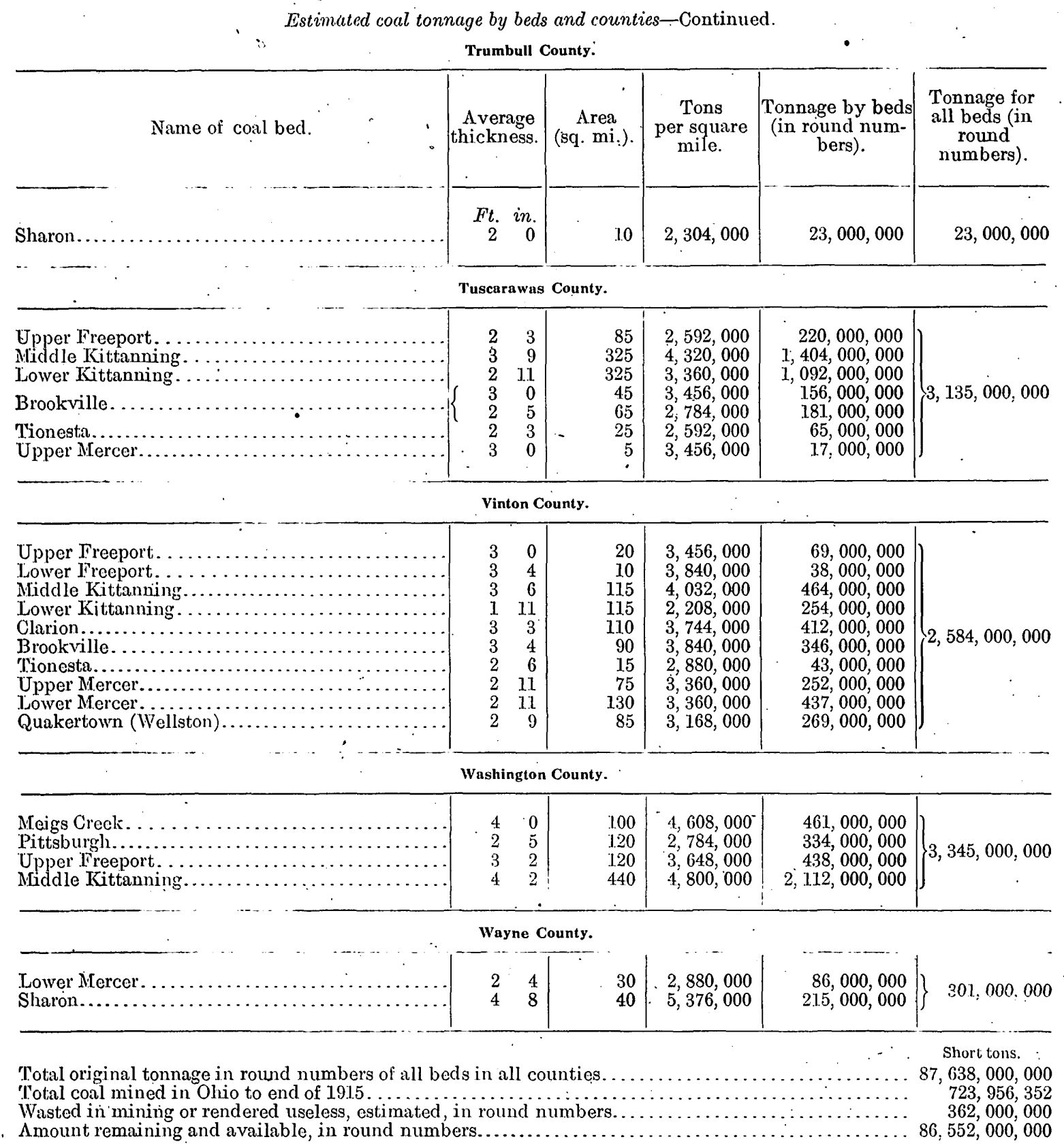

The principal part of the tonnage, according per cent of the total tonnage of the State. to this estimate, is contained in seven coal The first three beds contain 54,332,000,000 tons, beds, the outcrops of which are shown on the or more than 61 per cent of the total coal of coal maps described above. These beds, in the State. the order of their tonnage, are as follows: Middle Kittanning, 22,926,000,000 tons; Upper Frceport, 16,732,000,000 tons; Lower Kittanning, 14,674,000,000 tons; Lower Freeport, $6,971,000,000$ tons; Pittsburgh, 6,863,000,000 tons; Meigs Creek, 4,071,000,000 tons; and Pomeroy, $710,000,000$ tons. The total for these

From this showing it is evident that the total tonnage of those coal beds for which there are no outcrop maps is relatively small (only about 17 per cent of the entire estimate), and even if some errors have been made in estimating their areas and average thicknesses such errors will not greatly affect the total tonnage. beds is $72,947,000,000$ tons, or more than 8:3 Furthermore, the Anthony, Bear Run, "Lost $73210^{\circ}-17-5$ 
Seam," Mahoning, Mason, and Vandusen coal beds, which are thin local beds in the southern counties that are not included in the figures, will tend to offset an overestimate of other beds.

Recent detailed work done in southern Ohio by the State Survey ${ }^{1}$ materially affects the estimate for that area made in 1912. The recent investigations tend to reduce the total tonnage, although for a few beds the area and thickness were increased.

1 Ohio Geol. Survey Bull. 20, 1916.
In the earlier reports certain beds were said to be persistent and of good thickness throughout large areas, whereas recent detailed work in the southern counties shows that these beds vary in thickness and are restricted to small areas. Therefore, if the earlier reports contain the same kind of error regarding the coal in other parts of the State, the present estimate may be too large, but any further reduction is unwarranted until further detailed work is completed. 


\section{INDEX.}

$\Lambda$.

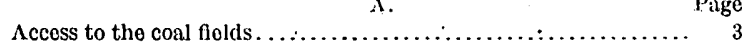

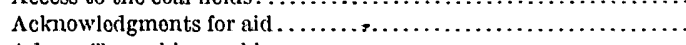

Adams Township, conl in.

Aid 'l'owsship, coal in.

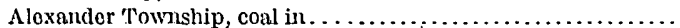

Allodonia, coal mined near.

Alloghouy formation, sequence of beds in .................. 42-43

A mes 'Township, coal in....

Amsterdam, coal minod near. . . ............................ 50

Analyses of Ohio coals............................... $82-85$

Anderson coal bed, description of.

Anthony coal bed, omission of, from tonnage estimate........... 95-96

Arches in the conl-benring rocks.

Athens County, Middle Kittanning coal in ...................... 52-55 tonnage in.

Uppor Freoport coal in...

.........59-60

, coal mined in ...................... (77, 74, 75

Aubum Township, coal mined in ......................... $\quad{ }_{50}$

Aurolius Township, coal in......................... 78,79

13.

Barnosville, coal mined at

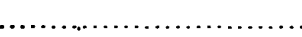

Barton, cool at.

Barton coal bed, description of ............................

Bear lRun coal bed, omission of, from tonnage estimate..........

Beavor Township, conl mined in.

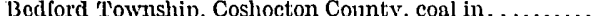

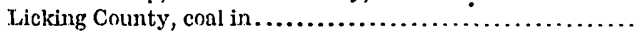

Meigs County, coal in.

Tuscarawas County, coal mined in

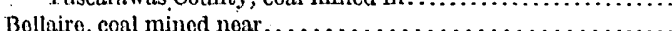

Bolmont and IFodoral Crook fields, Pittsburgh, coal betwe........

...... 68-69

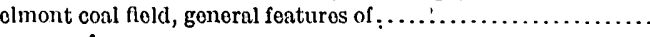
map of.

Bolmont County, Meigs Croek conl in ....................... $73-75$

Pittsburgh coal in . ................................... 63-65

tonnago in . . . . . . . . . .

Uniontown coal in. . . . . . . . . . . . . . . . . .

Washington conl in..

Waynesburg coal in...

Waynosburg " $A$ " coal in.

Borgholz, coal mined at.

Berno Township, conl in.

Bethel Township, coal mined in

Bibliography.

Bladen, coal mined near.

Bloom Township, Morgan County, coal in

mined in.

Bloom Township, Jackson County, coal mined in ........ 41,46

Bluo Rock Township, coal in ......................... 62

Bolivar, Tuscarawas County, coal mined at...

Bolivar coal, occurrence of.

Bowerston, coal near.

Brilliant, conl mined at.

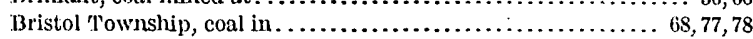

Broadwell, coal mined at

Brookfiold Township, cosl mined in

Brookville coal, tonnage of ............................... 91,92, 94, 95

Brookville (No. 4) coal bed, description of . . . . . . . . . . . . . .

Brown Township, coal mined in.

Brownsville (No. 12) coal, tonnage of.

Brush Croek coal, tonnage of.

Brush Creek limestone member, of the Conemaugh formation near Dexter, plate showing

Brush Creek Township, coal mined in

Butfaln Creek, coal mined on.

36
35
79
60
70
82
43
69
56
-85
62
-96
36
-55
90
-60
60
75
50
79

.

C. Page,

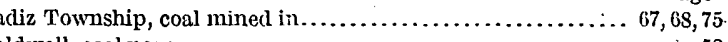

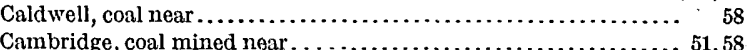
Cambridge coal, occurrence of.

Cambridge coal field; map of . . . . . . . . . . . . .

Canaan Township, coal in . . . . . . . . . . . . . . . . .

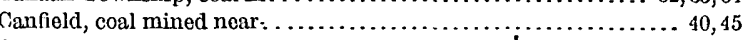

Cannel coal, occurrence of . .......................... $40,41,42,45$

Canton, coal mined at. . . . . . . . . . . .

Carroll County, Barton coal in. .......................... 62

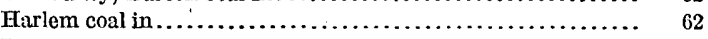

Lower Kittanning coal in.......................... $\mathbf{4 7}$

Mahoning coal in ....................

Middle Kittanning coal in.............................. $\quad .50$

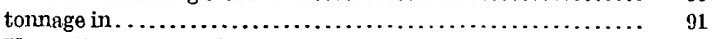

Upper Freeport coal in.............................. $57-58$

Carrollton, coal near........................................ 58

Center Township, Guernsoy County, coal in................. is

Morgan County, coal in .............................. 78

Cheshire 'Township, coal mined in ....................... $\quad 72$

Clarion coal, analyses of $\ldots \ldots \ldots \ldots \ldots \ldots \ldots \ldots \ldots \ldots \ldots \ldots \ldots \ldots, \quad s 2$

larion coal, quality of, for raising steam.................. 87 tonnage of............................... 91, 92, 93, 94, 95 Clarion (No. 4a) coal bed, description of ....................... $45-47$ Clark, Frank R., computation of the original coal content of the fields by.................................... 88-96.

Clark Township, coal in . . . . . . . . . . . . . . .

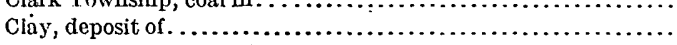

Clay Township, Gallia County, coal in.................. $\quad 70$

Muskingum County, coal in......................... $\quad 59$

Tuscarawas County, coal mined in ........................ 50

Clayton Township, coal mined in . . . . . . . . . . . . . .

Clinton Township, coal mined in . . . . . . . . . . . . . . .

Coal No. 10, tonnage of ............................... 90, 92

Coal Run, coal mined at. . ...............................

Coal Township, Jackson County, coal mined in................ 39, 40: Perry County, coal in..................................

Coke, use of coals for ......................47, 56, 57, 59, 65, 70, 86

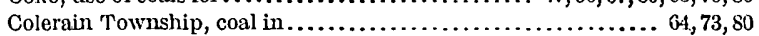

Columbiana County, Clarion coal in......................... 45

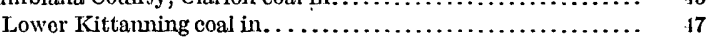

Mahoning coal in.......................................

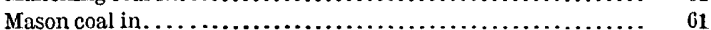

Middle Kittanning coal in.............................. 49-50

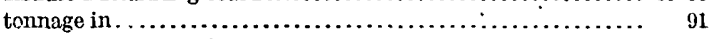

Upper Freeport coal in.............................. 57

Composition of Ohio coals.............................. 82-85

Condit, D. D., cited.............................. $60,61,62$

Conemaugh formation, coal bods in........................ 61-62

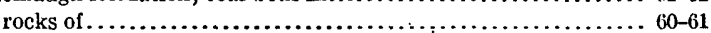

Congo, coal mined near................................ 53

Content of the fields, basis of estimate of. ..................... $88-89$ computation of .................................... 89-90, 95-96 data for estimate of.

Corning, coal mined near.............................. 53

quarry near, plate showing ........................... 60

Coshocton, coal mined near.................................

Coshocton County, Brookville coal in........................

Lower Kittanning coal in ........................... 48

Mercer coal in..................................... 41

Middle Kittanning coal in............................ 51

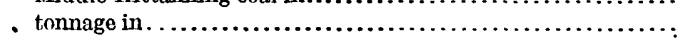

D.

Danford, coal mined at

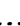

Decatur Township, coal mined in.

Deerfield, coal mined near. 
Dexter, Brush Creek limestone member of the Conemaugh formation near, plate showing

Dillonvale, coal mined at...

Domestic use of coals.

Dover Township, coal mined in

Dunkard coal bed, character of.

Dunkard group, coal beds of. sequence of beds in.

\section{E.}

East Liverpool, coal mined at

East Palestine, coal mined at

East Sparta, coal mined near...

Township, Noble County, coal mined in....... 76 Vinton County, coal mined in.....................40,41,44

Enoch Township, coal mined in

Extent of the coal fields.

F.

Fairfield Township, coal mined in.

"Fault," Jumbo, location of

Fearing Township, coal in.

Federal Creek and Belmont fields, Pittsburgh coal betweoin

Federal Creek field, Pittsburgh coal in

Finloy coal, occurrence of.

Flint Ridge, cannel coal, occurrence of

"Flint vein" occurr

Flushing Township, coal mined in................................ $64,73,74 ; 80$

Formations that bear coal.

Franklin Township, Coshocton County; coul in

Monroe County, coal in

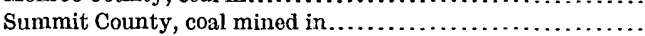

Furnaces, blast, use of coals in.

G.

Gallia County, Middle Kittanning coal in

Pomeroy coal in.

tonnage in. . .

Wilgus coal in.

Gas making uso of coals for.

German Township, coal in

Germantown, coal at

G'en Roy, coal in.

Glencoe, coal mined near

Glenwood, coal mined at.

(3) county, coal mined in.............74,80

Tus ^arawas County, coal mined in..................... 50

Green Township, Gallia County, coal in.................... $\quad 70$

Harrison County, coal in ........................... 67,68

Hocking County, coal in.

Green :eld Township, coal in.

Groff coal, occurremce of.

Guernsey County, Anderson coal in ..........................

Lower Kittanning coal in.

Meigs Creek coal in.

Pittsburgh coal in

tonnage in.

Upper Freeport coal in

Guyan Township, coal in.

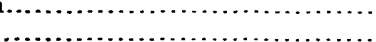

.

.

\section{H.}

Hamden Furnace, coal mined near.

Hamilton Township, Jackson County, conl mined in Lawrence County, coal mined in

Hardy Township, coal in

Harem coal, tonnage of .

Har'em coal bed, description of

Har'em Springs, coal mined at.

Harrison County, Anderson coal in

Har'em coal in

Meigs Creek coal in

Pittsburgh coal in.

tonnage in.

Uniontown coal in

Farrison Toumship, Gollia County,

Perry County, coal in

60
66
86
3,59
82
82
$1-82$


55
57
43
49
76
1,44
76
35.

Hart

Highland Township, coal in....................................

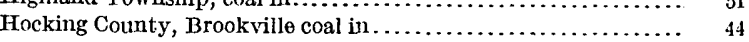

Lower Kittanning coal in ............................ 49

Mercer coal in....................................... 41

Middle Kittanning coal in ............................... $52-55$

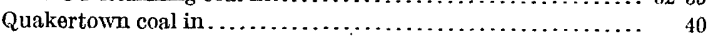

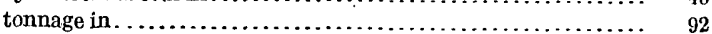

Hocking Valley coal fiold, map of . . . . . . . . . . . . . . . . . . . 52

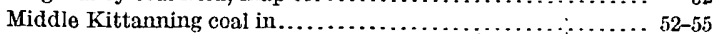

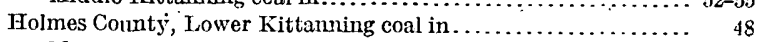

Mercer coal in ...........................................

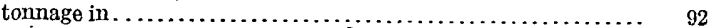

Homer Township, coal in ............................... 52,69

Hopewell Township, coal mined in ............................ ${ }_{41}$

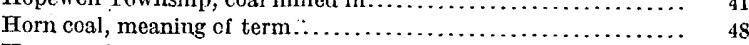

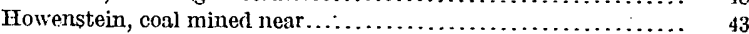

Hunter, coal mined near...................................

I.

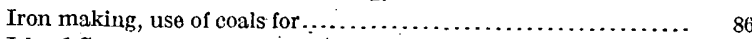

Island Creek, coal mined on..................................

J.

Jackson, coal mined at

Jackson County, Bronkvillecoa

Clarion coal in.

Lower Kittanning coal in

Mercer coal in....

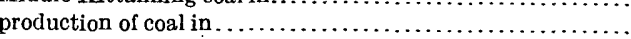

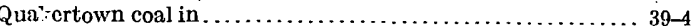

Sharon coal in......................... 37-38, 39

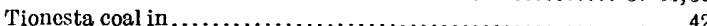

tonnage in.....

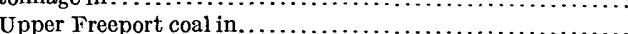

Jackson Hill coal bed. See Quakertown coal bed.

Jackson Township, Coshoton County, coal in...

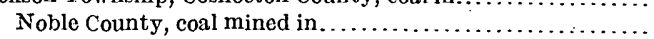

Jacksonville, coal mined at................................

Jacobsburg, coal near.

Jeffers coal, tonnage of ............................................. 91,93

Jefferson Count $y$, Harlem coal in....................... ${ }_{62}$

Lower Freeport coal in ............................ 56

I. ower Kittanning coal in . ......................... 48

Mahoning coal in ...................................

Middle Kittanning coal in.............................

Pittsburgh coal in.............................. $65-67$

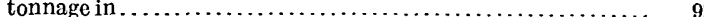

Jefferson Township, Coshocton County, coal mined in................

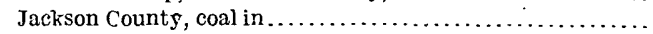

Noble County, coal mined in.

Tuscarawas County, coal mined in .

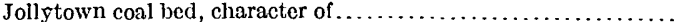

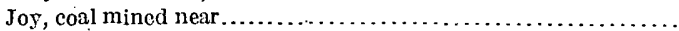

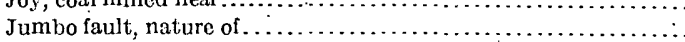

Justus, coal mined at..................................

\section{K.}

Kimbolton, coal near

L.

Lafagette 'Townst

Lafferty, shaft mine at, plate showing.

Lake Township, coal mined in.....

Lathrop, coal mined at.

cone made at.

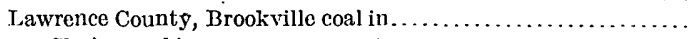
Clarion coal in.................................. $45-4$

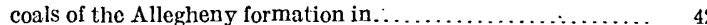

Lower Kittanning coal in ........................... 49

Mercer coal in..................................

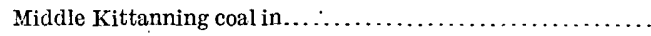

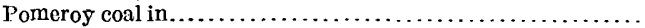

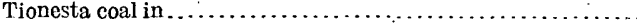

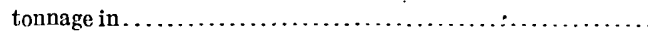

Upper Freport coal in.............................

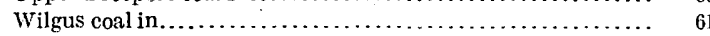$$
48
$$

.

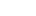

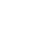


Page. Lawrence Township, Stark County, coal mined in.............
Tuscarnwas County, coal mined in....................

I.cetionia, conl mined near.

Liherts Township, Jackson County, coal mined in.

Washington Counts, coal mined in.

Lick Township, coal in.

Jicking County, Mercer coal in

tonnago in.

Lisbon, coal mined near..

Little Ico Creck, coal mined on.

Tocation of the coal flelds.

Lodi 'Township, coal in.

T.ord, N. W., acknowledgment to

I.ore City, coal near.

"I ost Seam" conl bed, omission of, from tonnage estimate....... $95-96$

T owcllville, coal mined near............................. 38

Tower Freeport coal, analyses of coke from. tonnage of.

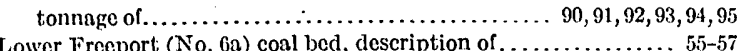

Tower Kittanning coal, analyses of........................ 83 coke from......................................... 86 quality of, for raising steam.

tonnago of.............................. 90,91, 92, 93, 94, 05

Lowor Kittanning (No. 5) coal bed, description of............ 47-49

T. ower Mercer coal, tonnage of.................... 91, 92, 93, 94, 95

t.ower Now l.exingtion coal, occurrence of.

Tudlow 'Township, coal mined in...

\section{M.}

McArthur, Vinton Counts, coal mined near.

Macksburg, coal mined at....

. 41,44,55

Madison 'Township, Columbiana County, coal mined in......... Jackson County, coal mined in ....................... Muskingum County, coal mined in.................. 51,52

Mahoning block coal, occurrence of......................... 38

Mahoning coal bed, description of ......................... 61 omission of, from tonnage estimate ................... 95-96

Mahoning County, Clarion coal in...

coals of the Allegheny formation in.

Mercer coal in.

tonnage in $\ldots \ldots \ldots \ldots \ldots \ldots \ldots \ldots \ldots \ldots \ldots \ldots \ldots \ldots \ldots \ldots \ldots \ldots \ldots \ldots \ldots \ldots \ldots \ldots \ldots \ldots$
Mahoning sandstono member, quarrs in, near Corning, plate showing.....

Malaga Township, coal in.

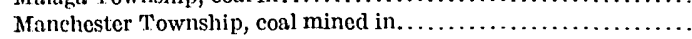

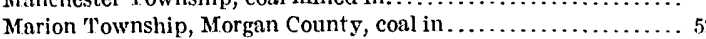
Noble County, coal mined in.

Martins Ferry, conl near.

Mason coal bed, description omission of, from tonnage estimate $\ldots \ldots \ldots \ldots \ldots \ldots \ldots \ldots \ldots \ldots, 95-96$

Mason Township, coal mined in....

Massillon coal ficld, description of ......................... 38-39

Mead Township, coal mined in ........................ $64-65,74-75$

Medina County, tonnage in................................. 93

Meigs County, Pomeroy coal in............................... $71-72$ tonnoge in.

Meigs Creok coal, analyses of. quality of, for raising steam tonnage of...

............. 90, 92, 93, 94, 95

, conl bed, description of .................. $72-80$

Mcigs Township, coal in................................ so

Meigsville Township, con mined in .................... 68,78

Mercer (Nos. 3 and $3 a$ ) coal beds, description of............... 40-42

Middle Kittanning coal, analyses of ....................... 83

coke from.

gas from.

quality of, for raising steam

tonnage of.....

Middle Kittanning (No. 6) coal bed, description of............ 49-55

Middlebranch, coal at...

Midvalo, coal mined near.

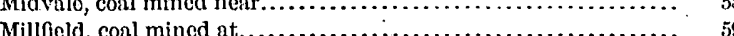

Milton Township, coal mined in......................39, 44, 46, 48, 49

Mincral, coal in.

Mineral City, conl mined in ............................... 47,48

Minerton, coal mined in.
Monorgahela formation, scquence of beds in ........ Page.

Monroe County, Meigs Creek coal in........................... ${ }_{80}$ rittsburgh coal in ........................................ tonnage in........................................ 93

Uniontown, coal in ................................. 81

Washington, coal in................................ $\$ 2$

Waynesburg, coal in.................................. 81

Monroc Furnace, Jackson County, coal mined at ............. 42

Monroe Township, Carroll County, coal in..................... 58

Perry County, coal mined in ......................... 52,59

Moonville, coal mined at................................. 55

Morgan County, $\Lambda$ inderson coal in ....................... 62

Meigs Creek coal in............................... $77-78$

tonnago in ......................................... 93

Mount Pleasant Township, coal in......................... 66

Muskingum County, Anderson coal in...................... 62

Brookville coal in ................................... 44

Lower Kittanning coal in ................................ is

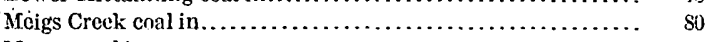

Mercer coal in ..................................... $4 \mathrm{t}$

Middle Kittanning coal in .......................... $51-52$

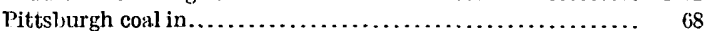

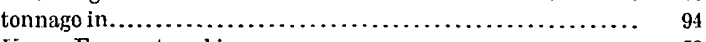

upper Freeport coal in.............................. 59

N.

New Berlin, coal mined near.................... 43

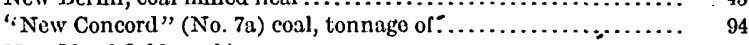

New Marshfield, coal in ..................................

New Philadelphia, coal mined near....................... 50

New Straitsville, coal mined near....................... 53

Newberry, J. S., cited....................................

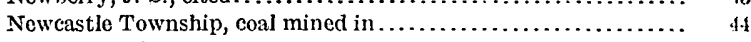

Newland coal, occurrence of ............................ $\quad 41$

Newton Township, coal mined in..................... $48,51,59$

Nimishillen Township, coal mined in........................ 50

Nineveh coal bed, character of.................................

Noble County, Anderson coal in........................ 62

Meigs Creek coal in................................ $766-77$

Pittsluurgh coal in .................................. os

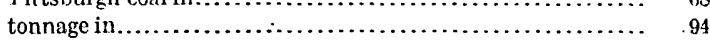

Norris coal, occurrence of................................. $\quad 59$

North Industry, coal mined near.......................... 43

"Norwich" (No. $7 \mathrm{~b})$ coal, tonnage of..............................

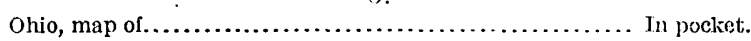

Ohio River, coal mined in.............................. $\quad 75$

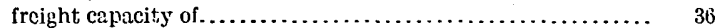

Ohio Township, coal in............................... 70

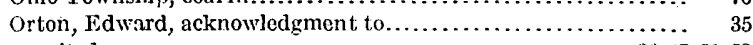

cited ...................................... $36,47,51,53$

Osnaburg Township, coal mined at..................... 50

Palos, coal mined at.................................... 59

Pease Township, coal mined in.......................... (i4, su

Perry County, Brookville coal in......................... 44

Lower Freeport coal in.............................. 56-57

Lower K.ittanning roal in..................................... $48-49$

Middle Kittanning coal in............................... $52-55$

Mercer coal in....................................... 41

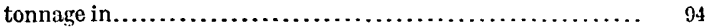

Jpper Freeport coal in................................. 59

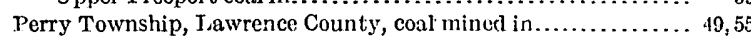

Monroe County, conl mined in........................ $\quad 80$

Muskingum County, coal mined in....................

Pike Township, Perry County, coal mined in ............... 4S, 52, 57 Stark County, coal in................................ 47

Pittsburgh coal, analyses of $\ldots \ldots \ldots \ldots \ldots \ldots \ldots \ldots \ldots \ldots \ldots \ldots, 84-85$

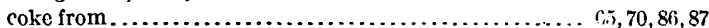
gas from.......................................... 87 quality of, for raising steam.............................. 87,88 strip pit on, plate showing............................. $\quad 66$ stripping of, with a steam shovel, plate showing........... 66 tonnage of $\ldots \ldots \ldots \ldots \ldots \ldots \ldots \ldots \ldots \ldots \ldots \ldots . .90,91,92,93,94,95$

rittsburgh (No. S) coal bed, description of..................... 62-71

shaft mine on, plate showing ......................... 56

pleasant Township, coal mined in ...................... 


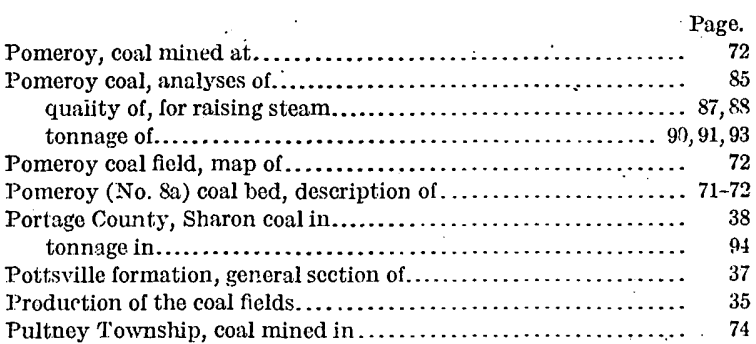

Quaker City, coal near.

Quakertown coal, analysis of.

tonnage of.

use of, for iron making.

Quakertown (No. 2) coal bed, description of ................... $39-40$

Range of the coals.

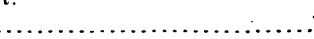

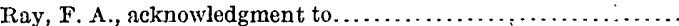

Redfeld, coal mined at.

Rendville, coal mined near.

Rich Fill Township, coal in

Richland Township, Bolmont County, cool mined in.

Vinton County, coal mined in

Rivers. See Streams.

Robbinsville, coal at.

Rockcamp, coal mined near.

Roger coal, occurrence of.

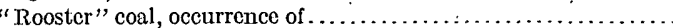

Rome Township, coal in...

Rose Township, coal mined in

Rush Run, coal mined at. .

Rutland, coal mined near.

St. Clairsville, coal mined near

Salem Township, coal mined in

Salineville, coal mined at.

Salisbury Township, coal in.

Salt Creek Township, coal in.

Salt Lick Township, coal in.

Sandy Township, Stark County, coal mined in.

Tuscarawas County, coal mined in

Scioto County, Clarion coal in.

Mercer coal in.

Tionesta coal in.

tonnage in . .

Scipio Township, coal in

Seneca Township, coal in. .

Sewickley coal bed, equivalent of.

Sharon coal, analyses of

tonnage of.

use of, for iron making

Sharon (No. 1) coal bed, description of . . . . . . . . . . . . . . . . . 38-39

Sharon Township, coal mined in.

Shawnee, coal mined near.

Sheridan, coal mined at

Sherrodsville, coal mined at.

Smith Township, coal in

Smithficld Township, coal mined in.

Somermeier, E. E., acknowledgment to .

Somerset Township, coal mined in.

Sonora, coal mined at.

coals of the Allegheny format.

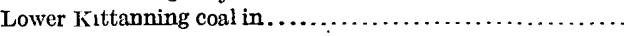

Mercer coal in.

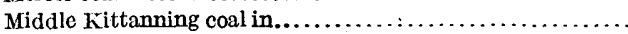

Sharon coal in..............................................

tonnage in.

Starr Township, coal in

Stauffer, C. R., acknowledgment to

cited.

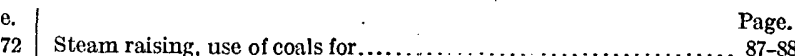

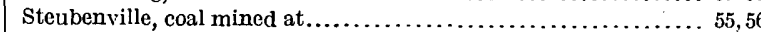

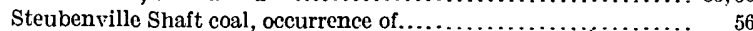

Stillwater, coal mined near . ..............................

Stock Township, coal mined in...........................

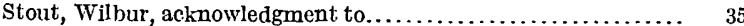

Streams, trenching of coal-bearing rocks by .....................

Strip coal, occurrence of . ...................................

Strip pit on Pittsburgh coal, plate showing..................

Stripping of Pittsburgh coal with a steam shovel, plate showing. . 66

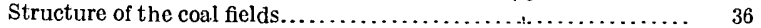

Sugar Creek Township, coal mined in .......................... 38

Summerfield, coal mined near .............................. $\quad 76$

Summit County, Sharon coal in ........................... $\quad 38$

tonnage in .

Sunfish Creek, coal mined on.............................. $\quad s 1$

Swan Creek field, Pittsburgh coal in....................... $70-71$

Swan Township, coal mined in................................ 44,5

Symmes Township, coal in............................ 59,60

T.

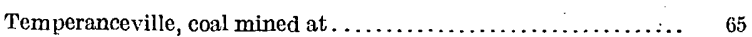

Tionesta coal, tonnage of ........................ 92,93,94,95

Tionesta (No. 3b) coal bed, description of . . . .

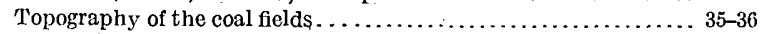

Toronto, coal in ...................................... 48

Trimble Township, coal mined in ......................... $52,53,59$

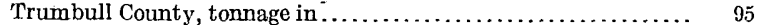

Trenching of coal-bearing rocks by streams...................... 36

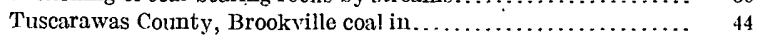

Lower Kittảnning coal in ................................ $47-48$

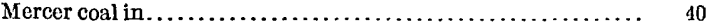

Middle Kittanning coal in........................... 50-51

Tionesta coal in .................................... 42

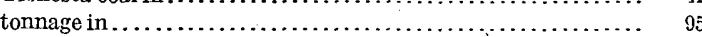

Upper Freeport coal in............................ is

Tuscarawas Township, coal mined in...................... 3s

U.

Uhrichsville, coal mined near.......................... 50

Union Township, Belmont County, coal mined in................ $64,74,80$

Morgan County, coal in ............................. $\quad 52$

Muskingum County, coal in.......................... 51,62

Uniontown coal, analyses of......................... $\quad 85$

Uniontown coal bed, description of..................... $80-\$ 1$

Upper Freeport coal, analyses of . . . . . . . . . . . . . . . . . . . coke from .................................................

quality of, for raising steam . . . . . . . . . . . . . . . . $87-88$ tonnage of................................ 90, 91, 92, 93, 94, 95

Upper Freeport (No. 7 ) coal bed, description of............... $57-60$ plate showing ......................................... 56 Upper Mercer coal, tonnage of................... 91,92, 93, 94, 95 Upper Township, coal mined in......................... 42,49 Utley, coke made at................................... 70 v. $v$.

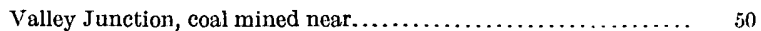

Vandusen coal bed, omission of, from tonnage estimate.......... $95-90$

Vernon Township, Scioto County, coal mined in ............... 42

Vinton County, Brookville coal in....................... 44

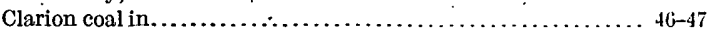

Lower Kittanning coal in ............................ 49

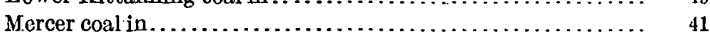

Middle Kittanning coal in.......................... 55

Quakertown coal in ................................ 40

Tionesta coal in ..................................... 42

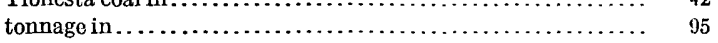

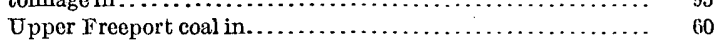

Vinton Township, coal mined in ......................... 46

Virginia Township, coal in ............................... $\quad 51$

W.

Ward Township, coal mined in......................... 52,53

Warren Township, Belmont County, coal in .................. 73

Jefferson County, coal in................................. 67

Warwick Township, coal mined in ......................... 51 
Page.

Webster block coal, occurronco of ......... Wellston, coal mined near....................................... Wellston coal bed. Sce Quakertown coal bed.

West Point, coal mined at.

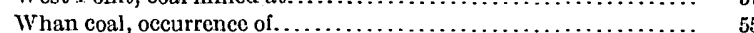

Wheeling Township, coal in .................................

White-cap, occurrence of

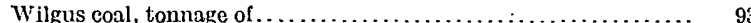

Wilgus coal bed, description of .............................. 61

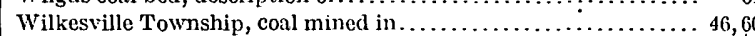

Windsor Township, coal in................................ 78

Winter's coal, occurrence of ............................... 44

witch Hazel, coal mined at ............................ 67

I.

York Township, $A$ thens County, coal mined in........... 52,59-60

Belmont county, coal in ..........................65,75

$z$.

Zaleski, Vinton County, coal mined near . $\ldots \ldots \ldots \ldots \ldots, 41,44,55$

Zanesville, coal mined at................................. 44,48,59 